\author{
UNIVERSIDADE DE SÃO PAULO \\ INSTITUTO DE ENERGIA E AMBIENTE \\ PROGRAMA DE PÓS-GRADUAÇÃ̃ EM ENERGIA
}

THAISA CAROLINA FERREIRA SILVA

UTILIZAÇÃO DE BIOGÁS DE ESTAÇÕES DE TRATAMENTO DE ESGOTO PARA FINS ENERGÉTICOS 
THAISA CAROLINA FERREIRA SILVA

\section{UTILIZAÇÃO DE BIOGÁS DE ESTAÇÕES DE TRATAMENTO DE ESGOTO PARA FINS ENERGÉTICOS}

Dissertação apresentada ao Programa de PósGraduação em Energia - Instituto de Energia e Ambiente - da Universidade de São Paulo como parte dos requisitos para a obtenção do título de Mestre em Ciências.

Orientadora: Prof $^{\mathrm{a}}$. Dr ${ }^{\mathrm{a}}$. Suani Teixeira Coelho

Versão Corrigida

(versão corrigida disponível na Biblioteca da Unidade que aloja o Programa e na Biblioteca Digital de Teses e Dissertações da USP) 
AUTORIZO A REPRODUÇÃO E DIVULGAÇÃO TOTAL OU PARCIAL DESTE

TRABALHO, POR QUALQUER MEIO CONVENCIONAL OU ELETRÔNICO, PARA FINS DE ESTUDO E PESQUISA, DESDE QUE CITADA A FONTE.

FICHA CATALOGRÁFICA

Silva, Thaisa Carolina Ferreira.

Utilização de biogás de estações de tratamento de esgoto para fins energéticos. / Thaisa Carolina Ferreira Silva; orientadora: Suani Teixeira Coelho. - São Paulo, 2015.

152 f.: il.; $30 \mathrm{~cm}$.

Dissertação (Mestrado - Programa de Pós-Graduação em Energia) EP / FEA / IEE / IF da Universidade de São Paulo.

1. Biogás. 2. Fontes alternativas de energia. 3. Tratamento de esgotos domésticos. I. Título. 


\section{UNIVERSIDADE DE SÃO PAULO \\ PROGRAMA DE PÓS-GRADUAÇÃO EM ENERGIA}

\section{THAISA CAROLINA FERREIRA SILVA}

"Utilização de biogás de estações de tratamento de esgoto para fins energéticos"

Dissertação defendida e aprovada pela Comissão julgadora em: 25/03/2015.

Banca examinadora:

Prof $^{a}$. Dr ${ }^{\mathrm{a}}$. Suani Teixeira Coelho - PPGE/USP

Orientadora e Presidente da Comissão Julgadora

Prof. ${ }^{a}$ Dr. ${ }^{\text {a }}$ Patrícia H. L. S. Matai - EPUSP/PPGE

Prof. Dr. Gustavo R. C. Posseti - ISAE/Sanepar 


\section{DEDICATÓRIA}

Dedico este trabalho aos meus pais, João Ayres e Rosemi, pela oportunidade para chegar até aqui; ao meu irmão João Gabriel pelo companheirismo; e ao meu marido, Adenilton, pela paciência.

Sou eternamente grata a todos pela extrema compreensão, apoio e motivação que deram a mim para que continuasse em frente com meus estudos. Mesmo que tenha ficado ausente em alguns momentos, meu coração sempre esteve com vocês. 


\section{AGRADECIMENTOS}

À Deus, meu senhor e pai, que me deu a graça da vida, inteligência e saúde.

À minha família, pelo apoio, carinho e amor, por todos esses anos de dedicação aos estudos.

À minha orientadora, Prof ${ }^{a}$. Dra. Suani Teixeira Coelho, pela grande oportunidade.

Ao meu coorientador Prof. Dr. Gustavo Rafael Collere Possetti, pela disponibilidade, incentivo e dedicação.

Aos colegas do IEE, pela colaboração.

Aos funcionários da Secretaria de Pós-Graduação do IEE pela ajuda e amizade.

Aos amigos, pelo incentivo. 


\section{RESUMO}

\section{SILVA, T. C. F. Utilização de Biogás de Estações de Tratamento de Esgoto para Fins}

Energéticos. 2015. 152 p. Dissertação (Mestrado em Ciências) - Programa de Pós-Graduação em Energia da Universidade de São Paulo - São Paulo, 2015.

O aproveitamento energético do metano corresponde a uma das opções mais interessantes de utilização deste subproduto do tratamento de esgotos domésticos que é um gás de médio poder energético e também um gás indutor de efeito estufa (GEE). Esta dissertação visa estudar as perspectivas concretas de geração de eletricidade a partir da recuperação e do uso do biogás oriundo do processo de tratamento anaeróbio de esgotos domésticos mediante atualização dos marcos regulatórios brasileiros e levantamento experimental das taxas de produção de biogás em Estações de Tratamento de Esgotos (ETEs). Nesse contexto, foram quantificadas, em tempo real, as taxas de produção de biogás e de metano de uma ETE de grande porte $\left(3556,8 \mathrm{~m}^{3}\right.$ tratados/hora), contendo 16 reatores UASB, alimentados com esgotos domésticos. Os resultados apontaram uma grande variação na carga orgânica recebida $(37.948 \pm 11.993) \mathrm{kg} /$ dia e na vazão de biogás da ETE $(84,30 \pm 26,64) \mathrm{Nm}^{3} / \mathrm{h}$, que podem ser influenciadas negativamente por eventos de chuva. De modo geral, as quantidades médias de vazão de biogás estimadas em estudos foram maiores que aquelas registradas a partir de medições, dependendo do método utilizado tal quantidade pode ser até 10 vezes maior que aquela verificada a partir de medições de campo. A potência elétrica máxima calculada em $233 \mathrm{~kW}$ se mostrou próxima da autossuficiência da ETE e as novas diretrizes regulatórias podem permitir a compensação de energia de outras ETEs do sistema. As emissões de metano podem reduzir significativamente, cerca de 7.476,7 t $\mathrm{CO}_{2} \mathrm{eq}$, quando do aproveitamento energético e possibilitam a venda de Certificados de Emissões Evitadas de Carbono. Concluise que, com o planejamento adequado, é possível haver interação entre saneamento ambiental e geração de energia com benefícios para ambos os setores.

Palavras-chave: Biogás, Energia Renovável, Tratamento Anaeróbio de Esgoto. 


\begin{abstract}
SILVA, T. C. F. Use of Biogas Wastewater Treatment Plants for Energy Purposes. 2015. 152 p. Dissertation (Master of Science) - Graduate Program on Energy, University of Sao Paulo - São Paulo, 2015.
\end{abstract}

The energy use of biogas corresponds to one of the most interesting use options of this by-product of wastewater treatment which is a mean-energy power and also a greenhouse gas. In this sense, this work aims to study the concrete prospects for electricity generation from the recovery and use of biogas derived from process of anaerobic treatment of wastewater by updating the Brazilian regulatory frameworks and experimental survey of biogas production rates in Wastewater Treatment Plants (WTP). In this context, were quantified in real time, biogas and methane production rates of a large WTP $\left(3556.8 \mathrm{~m}^{3}\right.$ treated / hour $)$ containing 16 UASB reactors fed with domestic wastewater. The results showed a wide variation in the incoming organic load $(37.948 \pm 11.993) \mathrm{kg} /$ dia and flow of biogas and methane from WTP $(84,30 \pm 26,64) \mathrm{Nm}^{3} / \mathrm{h}$, which can be negatively influenced by rainfall events. In general, the average quantities of biogas flow studies were estimated at greater than those recorded from measurements depending on the method used such amount can be up to 10 times higher than that found from field measurements. The maximum electric power estimated at $233 \mathrm{~kW}$ proved close to the WTP self-sufficiency and the new measures taken by the regulatory guidelines could allow power compensation in other WTPs system. Methane emissions can significantly reduce, about 7.476,7 $\mathrm{t} \mathrm{CO}_{2} \mathrm{eq}$, when the biogas was used for energy generation and may allow the sale of Avoided Carbon Emissions Certificates. So it is concluded that, with proper planning, it is possible to have interaction between environmental sanitation and power generation with benefits for both sectors.

Keywords: Biogas, Renewable Energy, Anaerobic Wastewater Treatment. 


\section{LISTA DE FIGURAS}

Figura 1 - Fluxograma típico do sistema de tratamento aeróbio convencional....................... 22

Figura 2 - Fluxograma do tratamento de esgotos em reatores UASB com pós-tratamento. .... 23

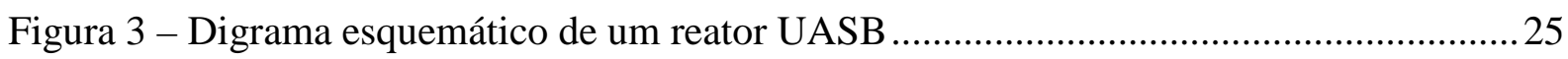

Figura 4 - Sequências metabólicas de digestão anaeróbia ...................................................29

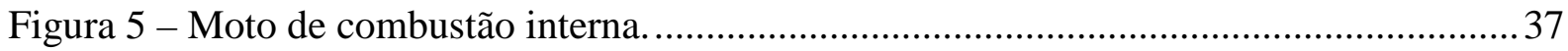

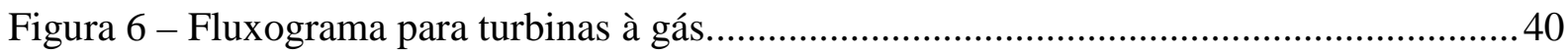

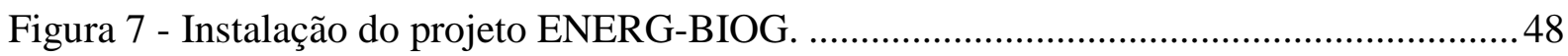

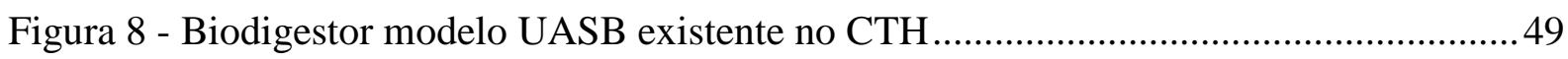

Figura 9 - Motor de combustão interna do projeto instalado no CRUSP . ..............................49

Figura 10 - Motor de combustão interna e gerador na ETE Ouro Verde em Foz do Iguaçu...50

Figura 11 - ETE Ouro Verde em Foz do Iguaçu. ................................................................ 51

Figura 12 - ETE Arrudas: Unidade de Cogeração....................................................................52

Figura 13 - Temperatura média global e concentração de $\mathrm{CO}_{2}$ na atmosfera desde 1880 .......60

Figura 14 - Emissões de $\mathrm{CO}_{2}$ por setor no Brasil em 2005 .................................................62

Figura 15 - Emissões de $\mathrm{CO}_{2}$ no período de 1990 a 2005 no Brasil por setor. ........................62

Figura 16 - Crescimento da concentração de metano na atmosfera e valores anuais de concentração para duas séries de medidas. .............................................................6 65

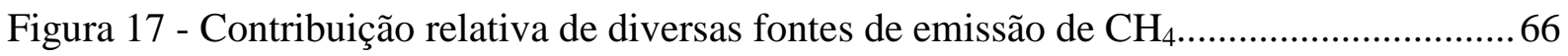

Figura 18 - Rotas de conversão de DQO e fluxos de metano em reatores UASB ................... 81

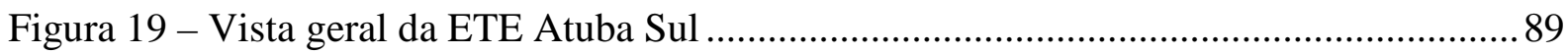

Figura 20 - Mapa de localização da ETE Atuba Sul ............................................................ 90

Figura 21 - Fluxograma do processo de tratamento da ETE Atuba Sul .................................91

Figura 22 - Equipamentos utilizado para realização das medições em campo. ....................... 92

Figura 23 - Estimativa do potencial de produção de biogás por meio de métodos reportados na literatura e comparação com os resultados de medições realizadas em campo........98

Figura 24 - Vazão de esgoto que entrou pelos reatores UASB ao longo do tempo ................ 101

Figura 25 - DQO recebida pelos reatores UASB ao longo do tempo...................................... 102

Figura 26- Carga orgânica que entrou e saiu pelos reatores UASB ao longo do tempo. ....... 103

Figura 27 - DBO afluente e efluente ao longo do tempo.................................................... 103

Figura 28 - Eficiência de remoção dos reatores UASB ao longo do tempo........................... 104

Figura 29 - Vazão média de biogás mensal em função do tempo para um intervalo de ano. 105

Figura 30 - Vazão média diária de biogás ao longo de um ano.............................................. 106 
Figura 31 - Curva de vazão de biogás para um intervalo de 10 dias .

Figura 32 - Volume total de chuvas na bacia de captação da ETE Atuba Sul, no período analisado.

Figura 33 - Número de dias de chuva por mês na bacia de captação da ETE Atuba Sul, no período analisado. 108

Figura 34 - Classificação e ocorrência das chuvas no período de análise. 109

Figura 35 - Precipitação de chuva x vazão média de biogás.

Figura 36 - Precipitação de chuva (mm) em função da vazão média de biogás $\left(\mathrm{Nm}^{3} / \mathrm{h}\right)$.

Figura 37 - Variação da vazão média de biogás de um dia em relação ao dia anterior em função da precipitação do dia analisado.

Figura 38 - Variação de vazão de biogás em relação ao dia anterior em função do volume de chuva do dia analisado.

Figura 39 - Relação entre os eventos consecutivos de chuva e redução na vazão de biogás do último dia de chuva em relação ao dia anterior sem chuva.

Figura 40 - Variação de vazão de biogás em relação ao dia anterior em função do volume de chuva do dia anterior ao dia analisado. 115

Figura 41 - Vazão média de biogás $\left(\mathrm{Nm}^{3} / \mathrm{h}\right)$ produzido e disponível nos reatores UASB da ETE Atuba Sul, de acordo com resultados de medições e de estimativas por diferentes métodos disponíveis na literatura.

Figura 42 - Estimativa da conversão da DQO em $\mathrm{CH}_{4}$ 118

Figura 43 - Histórico de consumo de energia elétrica da ETE Atuba Sul para o período entre 01/10/2011 e 01/10/2012.

Figura 44 - Histórico do custo de energia elétrica da ETE Atuba Sul para o período entre 01/10/2011 e 01/10/2012.

Figura 45 - Energia elétrica consumida e energia elétrica hipoteticamente gerada com biogás pela ETE Atuba Sul no período em análise.

Figura 46 - Energia consumida na ETE Atuba Sul com utilização da energia elétrica produzida na própria ETE. 126

Figura 47 - Diferença entre a energia elétrica consumida e a energia elétrica gerada no período em análise na ETE por meio de medições e estimativas com diferentes modelos.130 Figura 48 - Comparação das emissões evitadas ao utilizar os fatores de emissão do período de análise e referentes a outubro de 2013 até outubro de 2014 do SIN.....

Figura 49 - Comparação em $\mathrm{tCO}_{2}$ equivalentes entre o período analisado e com a adoção dos fatores de emissão referentes a um ano depois. 


\section{LISTA DE TABELAS}

Tabela 1: Comparação entre sistemas aeróbios e anaeróbios de tratamento de esgotos. ..........23

Tabela 2 - Propriedades físicas do metano, gás carbônico e gás sulfídrico............................... 32

Tabela 3 - Composição típica do biogás gerado em reatores anaeróbios tratando esgoto

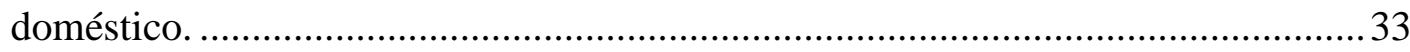

Tabela 4 - Características das tecnologias Comerciais ............................................................ 42

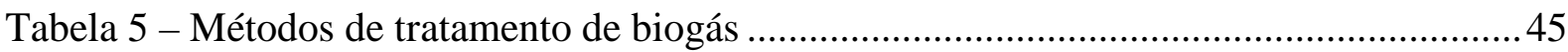

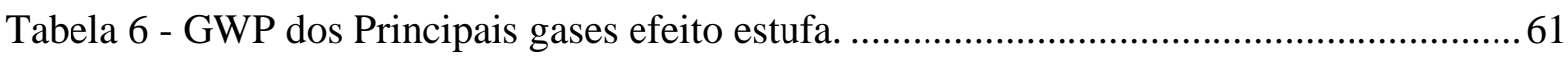

Tabela 7 - Relações unitárias de produção de metano, de biogás e de energia em reatores

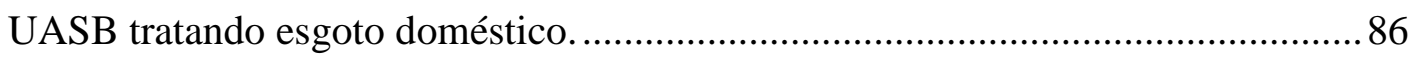

Tabela 8 - Classificação da intensidade da chuva....................................................................93

Tabela 9- Parâmetros utilizados para implementação do método proposto pelo IPCC (2006).

Tabela 10 - Parâmetros utilizados para implementação do método proposto pelo UNFCCC (2013).

Tabela 11 - Parâmetros utilizados para implementação do método proposto por Chernicharo (1997). 96

Tabela 12 - Parâmetros utilizados para implementação do método proposto por Lobato (2011)

Tabela 13 - Parâmetros utilizados para implementação do método proposto por CETESB (2006)

Tabela 14 - Fatores de emissão por geração de eletricidade no Sistema Interligado Nacional (SIN) 100

Tabela 15 - Dados médios do afluente e do efluente dos reatores UASB............................. 101

Tabela 16 - Pluviosidade diária no período de 09/11 a 19/11/2011 _...................................... 107

Tabela 17 - Comparação entre os dados adquiridos em campo e aqueles calculados por

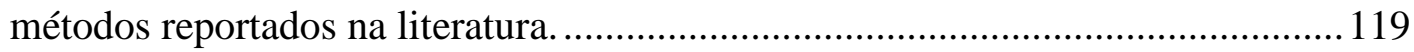

Tabela 18 - Produções médias anuais de biogás e potência química disponível 120

Tabela 19- Relações unitárias de produção de metano, de biogás e de energia em reatores UASB tratando esgoto doméstico

Tabela 20 - Tarifas praticadas pela empresa distribuidora de energia para o sistema horosazonal verde, grupo A4 no período entre julho de 2011 e junho e 2012. 
Tabela 21 - Tarifas praticadas pela empresa de energia para o sistema horo-sazonal verde, grupo A4, no período entre julho de 2012 a outubro de 2012 .............................. 123

Tabela 22 - Potencial de autoprodução mensal de energia elétrica e custo mensal evitado... 126

Tabela 23 - Custos evitados pela compensação energética. ............................................... 127

Tabela 24 - Custos evitados pela compensação energética e desorenação fiscal. .................. 128

Tabela 25 - Vazão mensal volumétrica e mássica de metano na ETE Atuba Sul................. 131

Tabela 26 - Emissões evitadas através do Sistema Interligado Nacional.............................. 132 


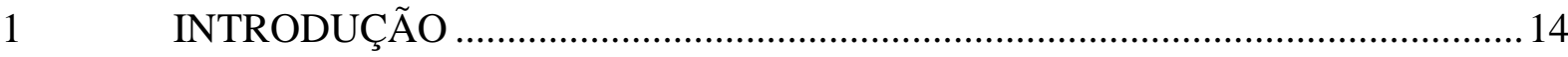

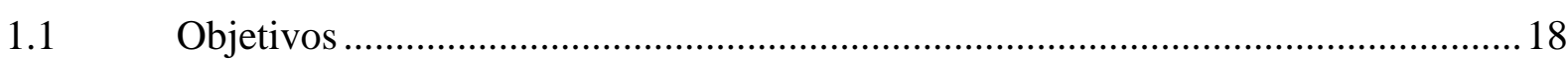

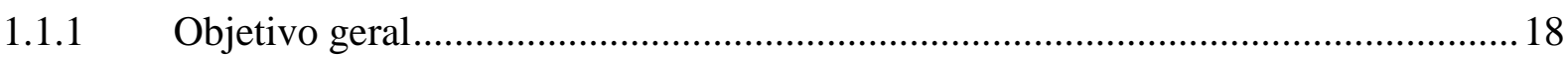

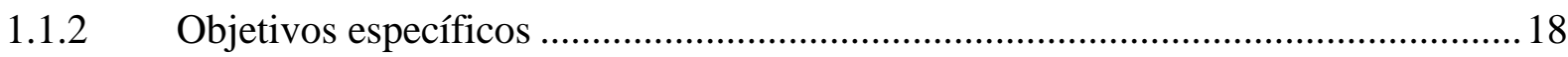

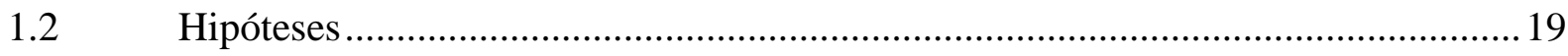

2 TRATAMENTO DE ESGOTO NO BRASIL ...................................................... 20

2.1 Situação atual do tratamento de esgotos no Brasil.................................................20

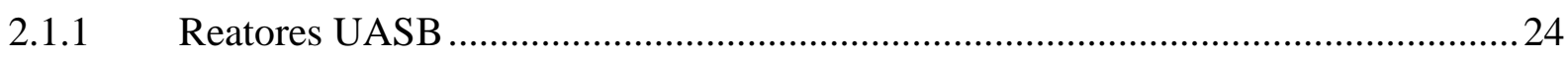

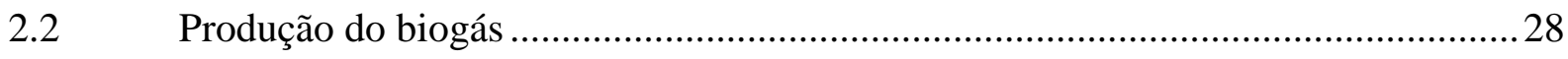

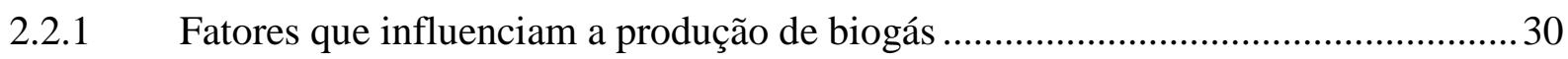

2.2.2 Propriedades físicas e químicas do biogás ............................................................. 32

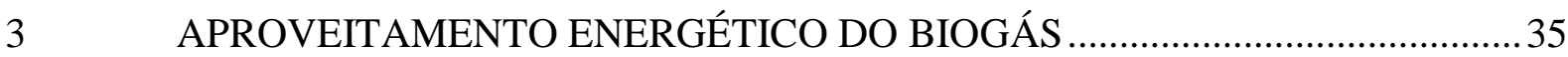

3.1 Principais tecnologias disponíveis para conversão energética do biogás .................36

3.1.1 Motores de combustão interna ........................................................................ 37

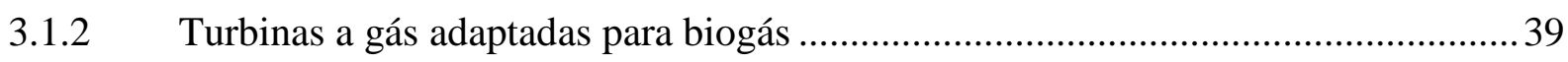

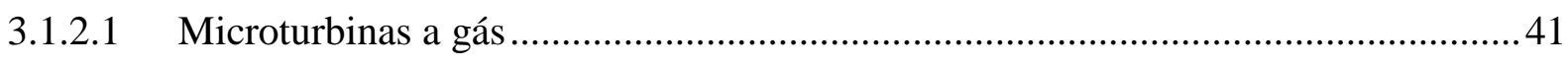

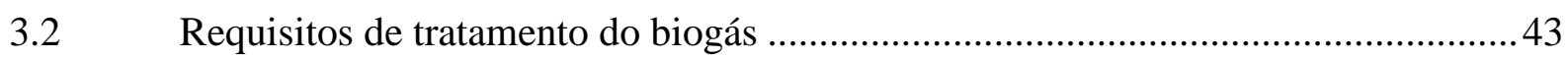

3.3 Exemplos de plantas de geração de energia elétrica a partir de biogás de ETEs no

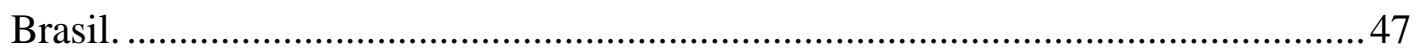

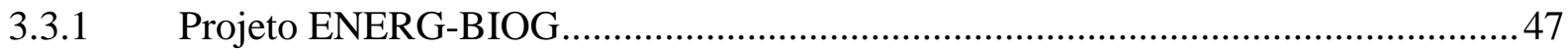

3.3.2 Programa de uso racional de energia e fontes alternativas (PUREFA) .................. 48

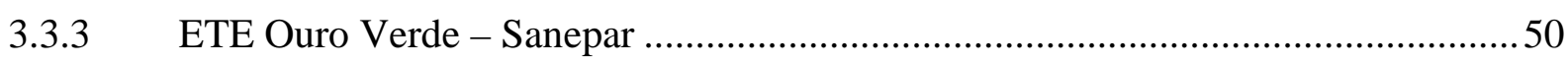

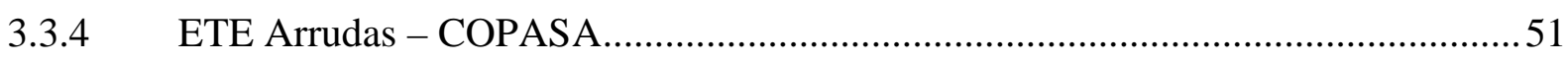

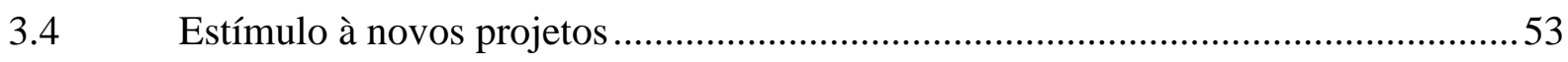

4 EMISSÃO DE GASES DE EFEITO ESTUFA ................................................ 58

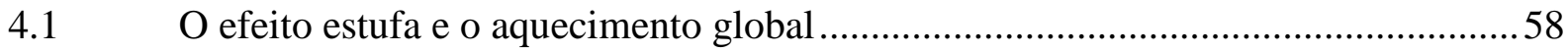

4.2 Mudanças climáticas: um problema global.........................................................59

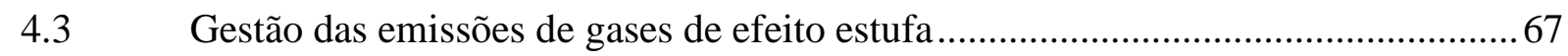

4.4 Mercado de certificado de emissões evitadas de carbono....................................... 71

5 MÉTODOS DE ESTIMATIVA DE PRODUÇÃO DE BIOGÁS ........................... 75

5.1 Método de estimativa IPCC (2006) .................................................................... 76 
5.2 Modelo de estimativa segundo UNFCCC (2013) ................................................ 78

5.3 Modelo matemático para cálculo do balanço de massa da DQO segundo

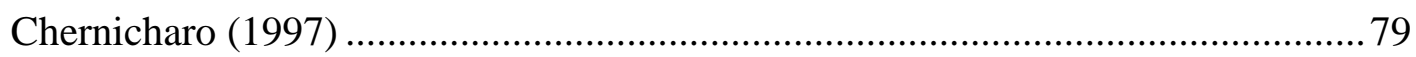

5.4 Modelo matemático para cálculo do balanço de massa da DQO e do potencial energético segundo Lobato (2011).................................................................... 80

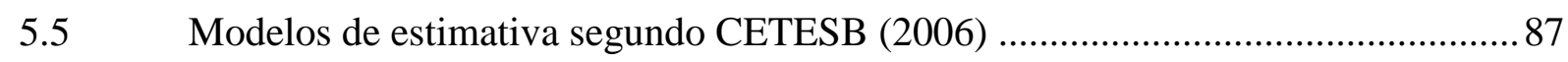

6 METODOLOGIA ADOTADA PARA EXECUÇÃO DO TRABALHO .............. 89

6.1 Parâmetros operacionais da ETE Atuba Sul. ........................................................ 89

6.2 Quantificação em tempo real da vazão produzida de biogás e de metano...............92 92

6.3 Avaliação da influência dos eventos de chuva na produção de biogás.....................93

6.4 Estimativa do potencial de produção de biogás por meio de métodos reportados na literatura e comparação com os resultados de medições realizadas em campo ........94

6.5 Avaliação dos custos evitados ao aproveitar o biogás para geração de energia

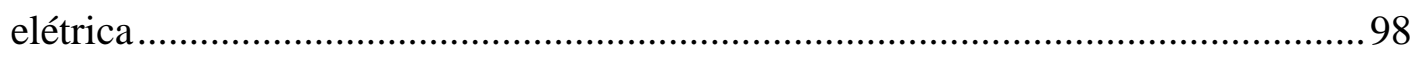

6.6 Emissões de gases de efeito estufa evitadas a partir dos resultados medidos .......... 99

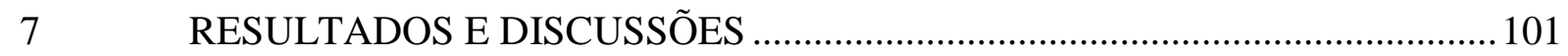

7.1 Análise dos parâmetros físico e químicos do esgoto da ETE Atuba Sul............... 101

7.2 Quantificação em tempo real das taxas de produção de biogás e de metano na ETE

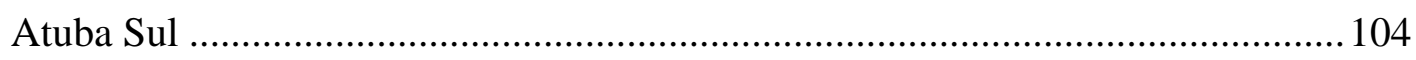

7.3 Avaliação da influência dos efeitos dos eventos de chuva na produção de biogás 108

7.4 Estimativa do potencial de produção de biogás por meio de métodos reportados na literatura e comparação com os resultados de medições realizadas em campo ..... 116

7.5 Avaliação dos custos evitados ao aproveitar o biogás para geração de energia

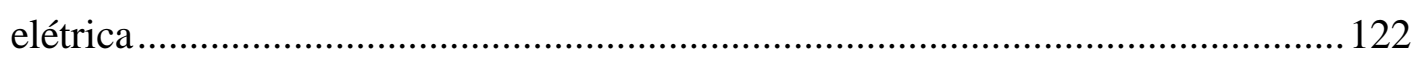

7.6 Redução das taxas de emissão de gases indutores do efeito estufa com a utilização de biogás para geração de eletricidade na ETE................................................... 131

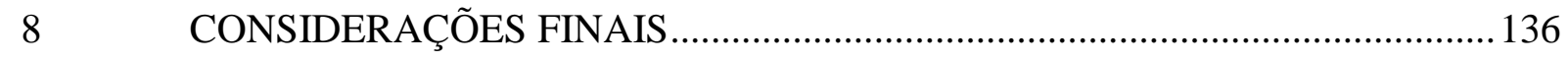

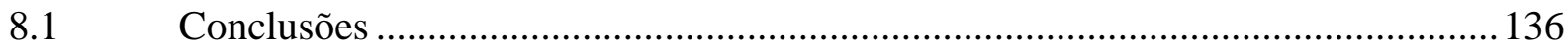

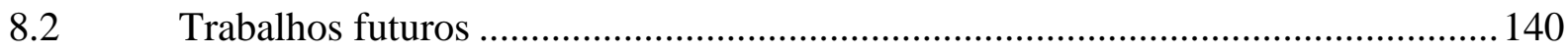

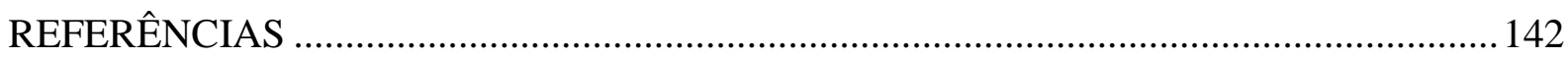




\section{INTRODUÇÃO}

Com a urbanização houve um aumento significativo por serviços de infraestrutura urbana, entre eles os sistemas de saneamento e as estações de tratamento de esgotos. Para garantir maiores investimentos no setor, sobretudo em zonas periféricas, é necessário aumentar a viabilidade econômica de suas instalações. Uma das possibilidades é aproveitar os resíduos gerados que, por vezes são caracterizados como um problema, em especial, o biogás emitido pelos sistemas de tratamento anaeróbio, que é constituído em grande parte por metano, um dos maiores contribuintes para a intensificação do efeito estufa.

Nos últimos anos, a utilização de tratamento anaeróbio de esgotos domésticos tem-se mostrado economicamente viável no Brasil. Para tanto, tem sido adotada essa tecnologia como instrumento para promoção da universalização do saneamento, apesar de grande parte da população ainda não dispor deste serviço. Segundo o Sistema Nacional de Informações sobre o Saneamento (SNIS) (MINISTÉRIO DAS CIDADES, 2014), apenas 56,3\% dos municípios avaliados possuem rede coletora de esgoto e apenas $69,4 \%$ do esgoto coletado é tratado.

Nesse setor tem-se observado o aumento da utilização de reatores anaeróbios para tal fim, sobretudo de reatores de fluxo ascendente e manto de lodo (UASB, upflow anaerobic sludge blanket). Isso aconteceu porque esses tipos de reatores, quando comparados aos sistemas de tratamento de esgoto aeróbios convencionais, demandam menor área para instalação, produzem menor quantidade de lodo, bem como exigem menor dispêndio com energia elétrica. Além disso, os reatores UASB tipicamente possuem baixo custo de implantação e possibilitam operações com elevados tempos de retenção de sólidos e baixos tempos de detenção hidráulica (CHERNICHARO, 2007).

Os reatores UASB ainda se destacam por disponibilizarem subprodutos com potencial de reaproveitamento, tais como o biogás que pode ser utilizado para fins energéticos. No entanto, quando o manejo do biogás não é realizado de maneira adequada, surgem problemas ambientais. Isso porque o biogás é composto majoritariamente por metano, um gás indutor de efeito estufa. Além disso, o biogás é constituído por substâncias odorantes como sulfeto de hidrogênio e mercaptanas.

Segundo Costa (2006), o biogás gerado nas estações de tratamento anaeróbio de esgotos é mais rico em metano que o similar produzido em aterros sanitários. 
O setor de saneamento, além de ser um dos responsáveis pela saúde da população, ainda faz uma interface entre o uso racional da água e de energia elétrica, fator evidenciado pela crise energética pela qual o país vem passando.

O tratamento de esgotos apresenta custos, entre eles os gastos com energia elétrica que são altos devidos às bombas de recalque das estações elevatórias, que levam o esgoto a longas distâncias, peneiras e desarenadores, responsáveis pelo pré-tratamento, sistemas de aeração (tratamento por lodos ativados), sistemas centrífugas e filtros prensas (presentes nas estações de maior capacidade para desaguamento de lodo). Atualmente, o gasto com energia elétrica é a segunda maior despesa da Companhia de Saneamento do Paraná (Sanepar), depois da folha de pagamento. O sistema de água responde por $91 \%$ do consumo de energia na empresa, $8 \%$ gasta o sistema de esgoto e 1\%, a área administrativa. A utilização da energia elétrica oriunda do processo de tratamento poderá, no futuro, gerar uma importante economia financeira.

Considerando a questão energética, que inclui o aproveitamento do biogás das ETEs para geração de energia térmica ou elétrica. Segundo Pecora (2006), o uso do biogás para fins energéticos é historicamente reconhecido, e amplamente fundamentado na literatura. No entanto, tal prática ainda é incipiente em ETEs brasileiras, em especial por conta da dificuldade em se viabilizar financeiramente investimentos. Além disso, há poucos estudos sobre a caracterização qualitativa e quantitativa do biogás recuperado em reatores UASB em escala real. Em geral, os trabalhos sobre a viabilidade de projetos de aproveitamento energético do biogás em ETEs são baseados em estimativas das taxas de produção de biogás, as quais, normalmente, não são compatíveis com as quantidades disponibilizadas na prática. Isso se explica pela dificuldade de medição do biogás, que demanda métodos bastante dispendiosos, coletas constantes do material em campo e realização de ensaios laboratoriais. Os estudos até então realizados, (COSTA, 2006; FRANÇA JR, 2008; PECORA, 2006) mostram que é difícil encontrar viabilidade financeira nestes projetos. No entanto, com a Resolução Normativa n $n^{\circ}$ 482/2012 da Agência Nacional de Energia Elétrica (ANEEL) isso pode ser diferente, como discutido neste trabalho. A ANEEL tem orientado que o setor estude o assunto, conforme Chamada Estratégica 14/2012.

A adequada utilização do biogás como insumo energético pode contribuir para a redução dos impactos ambientais das estações de tratamento e aumentar a eficiência do processo, reduzindo os gastos com energia elétrica e proporcionando maiores investimentos no setor. Além disso, projetos envolvendo a utilização mais eficiente do biogás possuem potencial de inserção em projetos de mecanismo de desenvolvimento limpo. 
Outro ponto importante é que em uma empresa de saneamento ambiental as emissões oriundas do tratamento de esgotos podem representar cerca de $89 \%$ de todas as emissões de gases indutores de efeito estufa da empresa, conforme Inventário de Emissões de Gases de Efeito Estufa da Sanepar - IGEES referente a 2013(SANEPAR, 2014).

No entanto, para atingir tais resultados faz-se necessário conhecer o comportamento do biogás gerado no tratamento de esgoto, para que se possa projetar adequadamente o sistema de aproveitamento energético, utilizando os equipamentos com a maior eficiência possível.

O estudo do aproveitamento do biogás gerado no tratamento de esgotos domésticos está inserido na temática das alternativas energéticas por meio de fontes renováveis. Logo, este estudo pretende colaborar com as pesquisas que visam a não dependência dos combustíveis fósseis, para aumentar a oferta de energia e possibilitar a geração descentralizada de energia próxima aos centros de carga, além de encontrar soluções ambientalmente sustentáveis para composição da matriz energética dos países. Além disso, a iniciativa pode melhorar o desempenho global do tratamento de esgotos domésticos, bem como reduzir o impacto ambiental das ETEs colaborando para aumentar a eficiência energética e operacional global do processo e, consequentemente, para fomentar o saneamento básico no País.

Neste sentido, é de grande relevância aproveitar energeticamente o metano presente no biogás (em particular no biogás de esgoto), conciliando a geração de energia elétrica renovável com a questão do saneamento ambiental. Para tal, o conhecimento experimental da quantidade e da qualidade do biogás gerado em uma estação de tratamento de esgotos domésticos - analisado sob a perspectiva dos marcos regulatórios atualizados - constitui informação imprescindível à tomada de decisão quanto à gestão destas emissões, dado que o seu aproveitamento como combustível para produção de energia elétrica exige quantidades mínimas para que o investimento seja sustentável economicamente.

Por esse motivo, esta dissertação visa avaliar a perspectiva de aproveitamento energético do biogás gerado no tratamento de esgotos por meio da caracterização quantitativa e qualitativa do biogás gerado em uma estações de tratamento anaeróbio de esgotos domésticos, ambas localizadas em Curitiba, a ETE Atuba Sul, por meio de medições passivas de biogás em tempo real.

Dessa forma, o trabalho foi estruturado da seguinte forma: 
A primeira seção apresenta uma contextualização sobre o trabalho, caracterizando o tema da pesquisa e as hipóteses que levaram aos objetivos do estudo. A segunda, terceira e quarta seções seguem apresentando a revisão bibliográfica pertinente ao assunto abordado e que visa dar suporte aos capítulos posteriores.

A quinta seção apresenta uma discussão sobre os métodos de estimativa para a produção de biogás e é seguida pela seção que apresenta a metodologia adotada para o trabalho, que foi dividido em cinco partes e contempla os dados adquiridos em campo, as medições realizadas, os dados de pluviosidade, o modelo de estimativa adotado para realização dos cálculos de produção de biogás, custos evitados a partir da geração de energia e contabiliza as emissões de gases de efeito estufa.

A sétima seção apresenta os resultados e discussões e é dividido em 6 partes: na primeira parte são analisados os parâmetros operacionais adquiridos em campo, em seguida os resultados da quantificação em tempo real das taxas de produção de biogás e de metano na ETE Atuba Sul, uma estação de grande porte que possui reatores anaeróbios. A seção apresenta também o padrão de comportamento do biogás durante o período de estudo, a possível influência dos eventos de chuva e uma comparação entre os dados adquiridos em campo e com modelos de estimativa das taxas de produção de biogás e de metano. Em seguida é tratado o potencial de geração de energia da ETE avaliada e desenvolvida uma análise dos custos evitados pela empresa ao aproveitar energeticamente o biogás para a geração de energia elétrica com base na Resolução Normativa n 482/2012 da ANEEL. Por fim, são apresentados os resultados das estimativas de redução das emissões de gases de efeito estufa que poderiam ocorrer se os gases forem recuperados energeticamente, bem como os benefícios que essa ação poderia trazer.

A oitava seção apresenta as considerações finais e recomendações da pesquisa. 


\subsection{Objetivos}

\subsubsection{Objetivo geral}

O objetivo geral deste trabalho é estudar as perspectivas concretas de geração de energia elétrica a partir da recuperação e do uso do biogás oriundo do processo de tratamento anaeróbio de esgotos domésticos mediante atualização dos marcos regulatórios brasileiros e levantamento experimental das taxas de produção de biogás e de metano.

\subsubsection{Objetivos específicos}

Os objetivos específicos desse trabalho são:

- Quantificar em tempo real as taxas de produção de biogás e de metano em uma ETE de grande porte, que utiliza reatores UASB alimentados com esgoto doméstico;

- Analisar as variações das propriedades físicas e químicas do esgoto doméstico dessa ETE induzidas por eventos sazonais e de chuvas, com o intuito de quantificar a influência dessas mudanças nas taxas de produção de biogás e de metano;

- Estimar as taxas de produção de biogás por meio de métodos reportados na literatura e confrontá-las com os resultados de medições realizadas em campo;

- Estimar o potencial real de geração de energia da ETE avaliada a partir dos dados adquiridos em campo;

- Avaliar os custos evitados ao aproveitar o biogás para geração de energia elétrica, sem e com os incentivos das diretrizes reportadas na Resolução Normativa n ${ }^{\circ}$ 482/2012 da ANEEL e ainda com a suposição de haver isenção de impostos no caso de compensação energética;

-Determinar a redução das taxas de emissão de gases indutores do efeito estufa associadas com a recuperação e com o uso energético do biogás produzido na ETE com o intuito de estabelecer os benefícios financeiros e ambientais que podem ser apropriados por companhias de saneamento. 


\subsection{Hipóteses}

Esta pesquisa foi fundamentada nas seguintes hipóteses:

- As medições em tempo real das taxas de produção de biogás e de metano oriundos de reatores UASB podem levar a estimativas mais acuradas e realistas da quantidade de energia disponível e sub-aproveitada em ETEs;

- A caracterização do biogás e o estabelecimento de padrões de comportamento, bem como a análise da influência das variações sazonais das propriedades físicas e químicas do esgoto doméstico que alimenta os reatores UASB pode auxiliar na definição das condições ótimas de produção de biogás, além de serem imprescindíveis para o adequado dimensionamento da planta de aproveitamento energético;

- Os métodos reportados na literatura tipicamente superestimam as taxas de produção de biogás, pois em geral são baseados em cálculos estequiométricos e/ou experimentos de laboratório que não refletem a realidade vivenciada nas ETEs. Portanto, é necessário verificar esses desvios e propor novos critérios para melhor prever a replicabilidade de plantas;

- O biogás pode ser utilizado em projetos de geração de energia elétrica (ALVES, 2000; BORGES et al., 2009; CENBIO, 2003; CHERNICHARO e STUETZ, 2008; COSTA, 2006; FRANÇA JR., 2008; GAIO, 2013; LOBATO, 2011; PECORA, 2006). No entanto, até hoje foi difícil viabilizá-los. A Resolução Normativa $n^{\circ} 482 / 2012$ da ANEEL pode ser um caminho para encontrar tal viabilidade;

- A recuperação e o uso energético do biogás em ETEs podem auxiliar na minimização das taxas de emissão de gases indutores do efeito estufa e, consequentemente, podem induzir benefícios significativos para as companhias de saneamento e para o meio ambiente. 


\section{TRATAMENTO DE ESGOTO NO BRASIL}

2.1 Situação atual do tratamento de esgotos no Brasil

Segundo o Ministério das Cidades (2014), pouco mais da metade dos municípios brasileiros $(56,3 \%)$ possuem serviço de esgotamento sanitário com rede coletora. É importante ressaltar que a estatística de acesso à rede coletora de esgoto refere-se apenas à existência do serviço no município, sem considerar a extensão da rede, a qualidade do atendimento, o número de domicílios atendidos, ou se o esgoto, depois de recolhido, é tratado. Apenas $69,4 \%$ do esgoto coletado é tratado. Além disso, cerca de $75 \%$ da população rural (23 milhões de habitantes) não possui sistemas de tratamento de esgoto ou utilizam apenas a fossa rudimentar, sendo que a população não assistida por esse serviço encontra-se nas camadas mais pobres (IBGE, 2009).

Em relação ao número de residências, apenas na região Sudeste mais da metade dos domicílios $(69,8 \%)$ possuem acesso à rede coletora. A segunda região em cobertura do serviço foi a Centro-Oeste $(33,7 \%)$, com resultado próximo ao da região Sul $(30,2 \%)$. Seguem-se as regiões Nordeste $(22,4 \%)$ e Norte $(3,8 \%)$.

No recorte por Unidade da Federação, os únicos estados com mais da metade dos domicílios atendidos por rede geral coletora de esgoto foram: Distrito Federal (86,3\%); São Paulo (82,1\%); e Minas Gerais $(68,9 \%)$. O Rio de Janeiro $(49,2 \%)$ e o Paraná $(46,3 \%)$, com quase metade dos domicílios atendidos, se situaram acima da média nacional (44,0\%), enquanto os demais apresentaram menos de $35 \%$ de cobertura, ficando as menores proporções com os Estados do Amapá (3,5\%), Pará (1,7\%) e Rondônia (1,6\%). Isso demonstra que ainda há muito que se investir no setor, apesar de existir uma meta do governo federal de universalizar os serviços de saneamento até 2033, instituída por meio do Plano Nacional de Saneamento Básico (Plansab) (PLANSAB, 2013).

A geração de energia pode colaborar para melhorar esse sistema, ao utilizar um sistema de tratamento ao priorizar a alta eficiência de tratamento para promover maior geração de energia, o que pode ajudar a propiciar maior interesse no setor. 


\subsection{Tipos de Tratamento de Esgotos}

A água é utilizada de diversas maneiras no dia-a-dia, para vários usos finais nos diferentes setores. Depois de eliminada, ela passa a ser chamada de esgoto. A origem do esgoto pode ser, doméstica, pluvial (água das chuvas) e industrial (água utilizada nos processos industriais). O esgoto é constituído basicamente por: sólidos em suspensão, matéria orgânica, nutrientes, organismos patogênicos e água.

Se o esgoto não receber tratamento adequado, ele pode se transformar em um vetor de doenças, pelo contato direto ou por meio de ratos, baratas e moscas, causando prejuízos à saúde pública. Ele pode, ainda, poluir rios e fontes d'água, afetando os recursos hídricos e a vida vegetal e animal (FRANÇA JR., 2008).

Além disso, o esgoto não tratado lançado no meio ambiente pode provocar impactos ambientais significativos, como a eutrofização e o aumento da demanda bioquímica de oxigênio - DBO - dos corpos receptores (COSTA, 2006).

Daí vem a necessidade de realizar o tratamento adequado desse efluente, visando reduzir o teor de agentes contaminantes e o potencial poluidor. O seu uso ou disposição final não devem alterar significativamente o meio ambiente, mantendo o equilíbrio natural do entorno (COSTA, 2006). De modo geral, o tratamento consiste em separar as partes líquidas e sólidas do esgoto, para tratá-las separadamente, reduzindo ao máximo a carga poluidora, sem que o meio ambiente seja prejudicado (FRANÇA JR., 2008).

Atualmente, existem inúmeros processos para o tratamento de esgoto, individuais ou combinados. A decisão pelo processo a ser empregado deve levar em consideração, principalmente, as condições do curso d'água receptor (estudo de autodepuração e os limites definidos pela legislação ambiental) e da característica do esgoto bruto gerado. É necessário certificar-se da eficiência de cada processo unitário e de seu custo, além da disponibilidade de área (IMHOFF e IMHOFF, 1996).

Os processos de tratamento de esgoto podem ser divididos em aeróbios e anaeróbios, ambos precisando de uma etapa de pré-tratamento que consiste no gradeamento mecânico e desarenação. Nessas etapas os materiais sólidos e areias que chegam com os esgotos são contidos (PECORA, 2006). Em condições naturais, a decomposição aeróbia necessita três vezes menos tempo que a anaeróbia e dela resultam gás carbônico, água, nitratos e sulfatos. $\mathrm{O}$ 
resultado da decomposição anaeróbia (sem presença de oxigênio) é a geração de gases como o sulfídrico e o metano.

No caso do tratamento aeróbio (com presença de oxigênio), o esgoto segue para tanques de aeração onde ocorre o processo de introdução de oxigênio na massa líquida. Isso é feito para dar condições ao desenvolvimento dos micro-organismos aeróbios, que só vivem em presença de ar e assimilam matéria em grande quantidade no esgoto. Em condições aeróbias a matéria orgânica é convertida a gás carbônico, água e biomassa. Trata-se de um processo que requer maiores quantidades de energia elétrica, quando comparado ao tratamento anaeróbio.

Em seguida, o efluente vai para decantadores que objetivam sedimentar o lodo por gravidade, sendo o líquido tratado coletado na parte superficial por meio de uma calha, conduzido por um canal e lançado no corpo d'água (Figura 1).

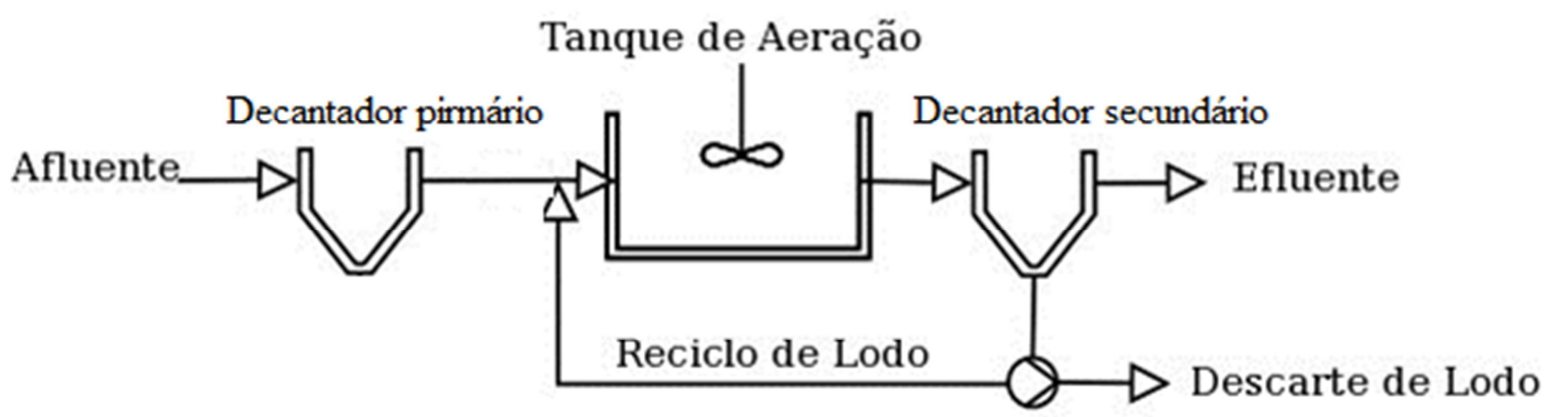

Figura 1 - Fluxograma típico do sistema de tratamento aeróbio convencional

Fonte: Adaptado de Von Sperling (1995).

No processo de tratamento anaeróbio, por sua vez, a degradação do esgoto ocorre por meio de bactérias anaeróbias (que não necessitam de oxigênio para sobreviverem). No processo de degradação anaeróbia, a matéria orgânica é transformada em gás carbônico, metano, água e biomassa (lodo). Sendo que a produção de biomassa é significativamente menor quando comparada aos processos aeróbios, pois a taxa de crescimento dos microrganismos anaeróbios é baixa, sendo que a energia potencial do resíduo vai em parte para a biomassa e parte para o metano.

No Brasil, até a década de 70, o uso de processos anaeróbios para o tratamento de esgotos era restrito basicamente às lagoas anaeróbias, aos decanto-digestores (fossas sépticas 
e tanques Imhoff, para a estabilização do lodo retido) e aos digestores de lodos produzidos no tratamento da fase líquida de estações de tratamento de esgotos.

No começo da década de 80, iniciavam-se no Brasil estudos para a utilização do reator anaeróbio do fluxo ascendente e manta de lodo (reator UASB), desenvolvido na década anterior na Holanda, para o tratamento de esgotos sanitários. Essas estações são compostas basicamente por reatores anaeróbios (UASB), que podem ser seguidas por pós-tratamento (Figura 2).

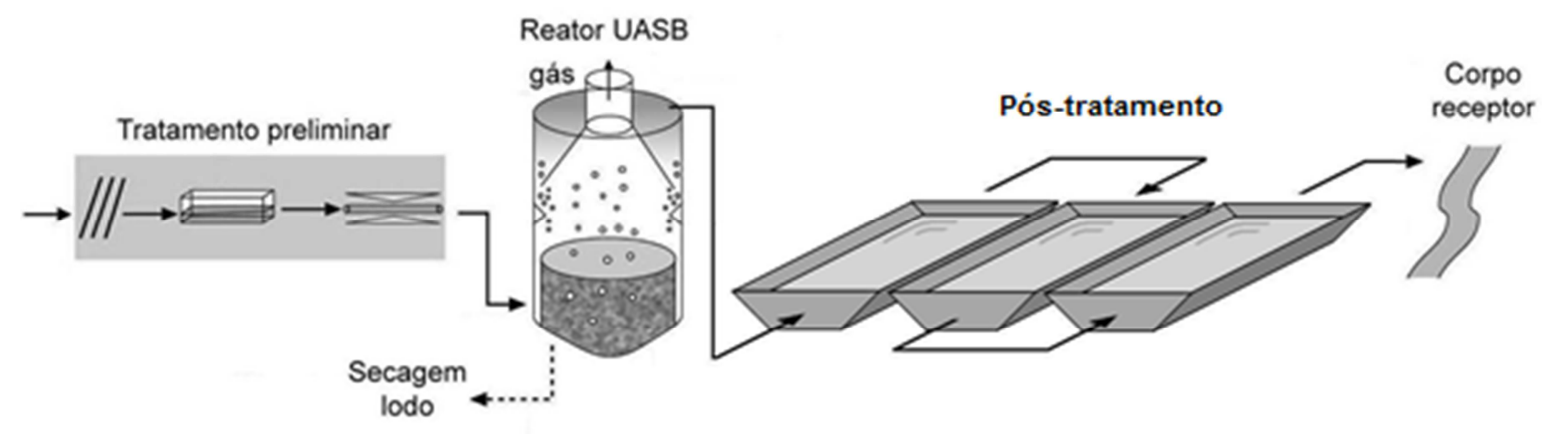

Figura 2 - Fluxograma do tratamento de esgotos em reatores UASB com pós-tratamento.

Fonte: Chernicharo (1997)

Neste caso, após o esgoto passar pelo pré-tratamento ele segue para o reator UASB, no interior do qual o líquido interage com um manto de lodo que se forma no fundo do tanque, rico em bactérias.

O esgoto, após percorrer este manto, retém e decompõe a matéria orgânica. Quando o esgoto tratado não atende às exigências dos órgãos ambientais, ele é coletado e enviado à etapa de pós-tratamento.

Resumindo, os sistemas aeróbio e anaeróbio possuem características que geram vantagens ou desvantagens. Essas características devem ser analisadas durante a escolha do processo de tratamento, de acordo com o local a ser implantado. A Tabela 1 apresenta uma comparação de algumas das principais características dos processos aeróbios e anaeróbios.

Tabela 1: Comparação entre sistemas aeróbios e anaeróbios de tratamento de esgotos.

\begin{tabular}{lll}
\hline Características & Sistemas aeróbios & Sistemas anaeróbios \\
\hline Eficiência & Maior & Menor \\
Partida & Rápida & Pode ser lenta \\
\hline
\end{tabular}




\begin{tabular}{lll}
\hline Características & Sistemas aeróbios & Sistemas anaeróbios \\
\hline Consumo de energia & Alto & Inexpressivo \\
Estabilidade & Boa, Sob aeração & Sensível \\
Custo de implantação & Maior & Menor \\
Custo de manutenção & Maior & Menor \\
Produção de odores & Menor & Maior \\
Produção de Lodo & Maior & Menor \\
\hline
\end{tabular}

Fonte: Adaptado de Chernicaro (1997)

O esgoto tratado, independente do processo, deverá estar livre de qualquer tipo de substância nociva à flora ou fauna, atendendo ao disposto na Resolução n. ${ }^{\circ}$ 357/2005, alterada pela Resolução 410/2009 e pela 430/2011 do Conselho Nacional de Meio Ambiente (CONAMA).

O lodo gerado em ambos os tratamentos é bombeado ao adensador, onde o lodo é concentrado, e depois recalcado para as lagoas ou leitos de secagem, com o intuito de reduzir o teor de umidade, para facilitar a disposição final do mesmo sendo que em ETEs de médio e grande porte há, tipicamente, sistemas mecânicos de desaguamento como prensas e centrífugas.

Levantamentos feitos em vários países indicam que o volume de lodo produzido em uma Estação de Tratamento de Esgoto representa cerca de 1-2\% do volume de esgoto tratado, entretanto seu tratamento e disposição final chega a atingir entre $30 \%$ e $50 \%$ do custo operacional da ETE (VON SPERLING ET AL, 2001). De forma que o gerenciamento do lodo de esgoto proveniente de estações de tratamento é uma atividade de grande complexidade e alto custo, que, se for mal executada, pode comprometer os benefícios ambientais e sanitários esperados destes sistemas (Luduvice, 2001).

\subsubsection{Reatores UASB}

O reator UASB começou a ser aplicado a partir de estudos sobre processos anaeróbios para o tratamento de esgotos sanitários desenvolvidos por Lettinga et al. (1983) tornando-se familiar entre projetistas e pesquisadores brasileiros, em especial no Estado do Paraná, onde passou a ser amplamente empregado. 
O reator UASB (Figura 3) consiste basicamente de um tanque Imhoff de fluxo vertical, apresentando câmaras de sedimentação e digestão anaeróbia sobrepostas, no qual a sedimentação ocorre na câmera superior, na qual os sólidos sedimentados passam por uma abertura no fundo desta, dirigindo-se para o compartimento inferior. Na câmera inferior, o lodo acumulado sofre a digestão anaeróbia (CHERNICHARO, 1997). Resumidamente, o reator UASB é um biodigestor com retenção interna de lodo, com a incorporação de um separador diferente para os sólidos suspensos e para o gás (LETTINGA et al., 1983).

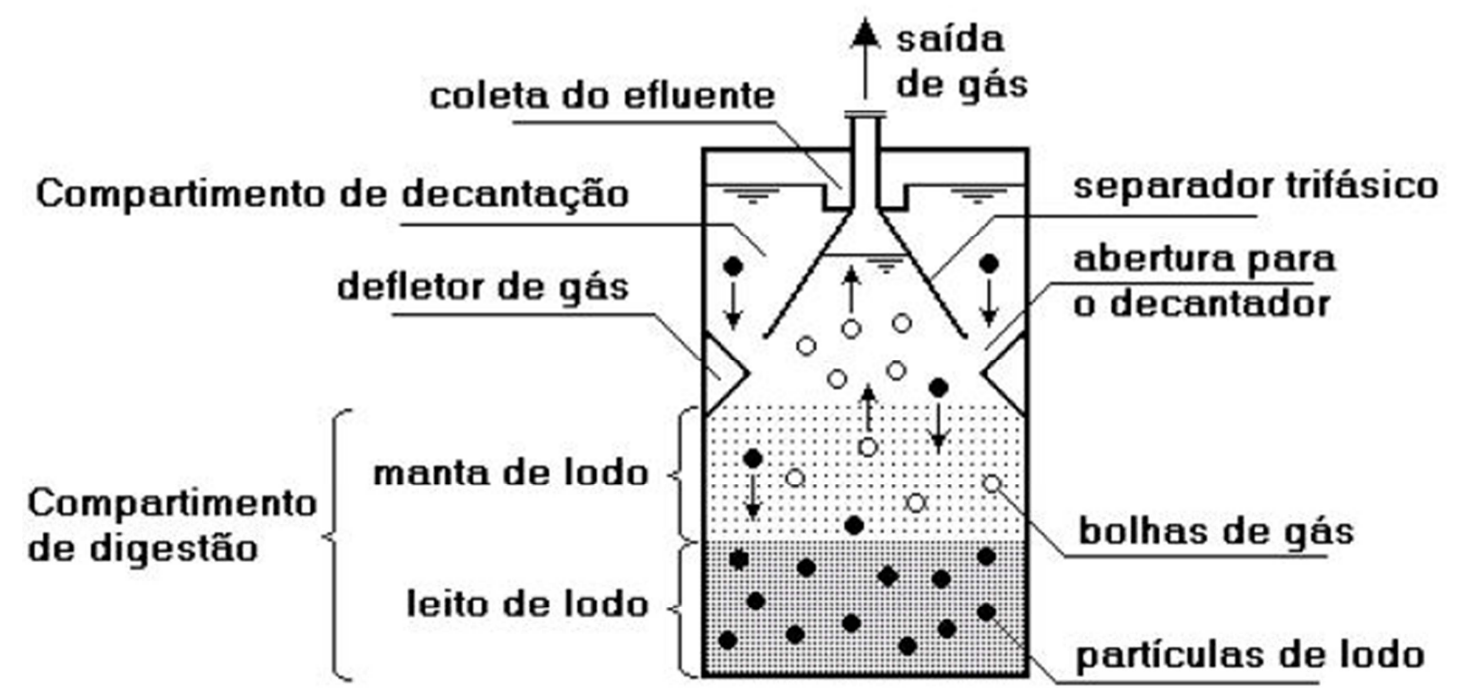

Figura 3 - Digrama esquemático de um reator UASB

Fonte: Chernicharo (2007).

A água residuária após entrar e ser distribuída uniformemente pelo fundo do reator UASB, flui pela zona de digestão, onde se encontra o leito de lodo, ocorrendo a mistura do material orgânico nela presente com o lodo. Os sólidos orgânicos suspensos são quebrados, biodegradados e digeridos através de uma transformação anaeróbia, resultando na produção de biogás e no crescimento da biomassa bacteriana. $\mathrm{O}$ biogás segue em trajetória ascendente com o líquido, após este ultrapassar a camada de lodo, em direção ao separador de fases. É evitada a entrada do gás produzido no sedimentador, por meio da colocação de defletores, e este é encaminhado somente a determinadas áreas do reator.

No separador de fases, a área disponível para o escoamento ascendente do líquido deve ser de tal forma que o líquido, ao se aproximar da superfície líquida livre, tenha sua velocidade progressivamente reduzida, de modo a ser superada pela velocidade de 
sedimentação das partículas, oriundas dos flocos de lodo arrastados pelas condições hidráulicas ou flotados. Isto possibilita que este material sólido que passa pelas aberturas no separador de fases, alcançando a zona superior do reator, possa se sedimentar sobre a superfície inclinada do separador de fases. Naturalmente que esta condição dependerá das condições hidráulicas do escoamento.

Desse modo, o acúmulo sucessivo de sólidos implicará consequentemente, no aumento contínuo do peso desse material o qual, em um dado momento, tornar-se-á maior que a força de atrito e, então, deslizarão, voltando para a zona de digestão, na parte inferior do reator. Assim, a presença de uma zona de sedimentação acima do separador de fases resulta na retenção do lodo, permitindo a presença de uma grande massa na zona de digestão, enquanto se descarrega um efluente substancialmente livre de sólidos sedimentáveis (VAN HAANDEL E LETTINGA, 1994).

Na parte interna do separador de fases fica a câmara de acumulação do biogás que se forma na zona de digestão. O projeto do UASB garante os dois pré-requisitos para digestão anaeróbia eficiente: a) através do escoamento ascensional do afluente passando pela camada de lodo, assegura-se um contato intenso entre o material orgânico e o lodo e b) o decantador interno garante a retenção de uma grande massa de lodo no reator (VAN HAANDEL E LETTINGA, 1994). Com o fluxo ascendente a estabilização da matéria orgânica ocorre na zona da manta de lodo, não havendo necessidade de dispositivos de mistura, pois esta é promovida pelo fluxo ascensional e pelas bolhas de gás (OLIVA, 1997).

Em relação à forma dos reatores em planta, estes podem ser circulares ou retangulares. Os reatores de seção circular são mais econômicos do ponto de vista estrutural, sendo mais utilizados para atendimento a pequenas populações, usualmente com uma unidade única. Para atendimento a populações maiores, quando a modulação se torna necessária, os reatores retangulares passam a ser mais indicados, uma vez que uma parede pode servir a dois módulos contíguos (VAN HAANDEL E LETTINGA, 1994).

Algumas das principais condições encontradas nesse tipo de reator são: a separação do biogás, do esgoto e do lodo; o lodo anaeróbio deve apresentar uma boa capacidade de sedimentação, e, principalmente, deve desenvolver um lodo (biomassa) de elevada atividade, na forma de flocos ou de grânulos (1 a 5 mm de diâmetro); o esgoto deve ser introduzido na parte inferior do reator. 
Segundo Pecora (2006), o contato necessário entre a água residual e o lodo é eficiente, uma vez que o próprio gás gerado na manta de lodo é suficiente para manter o lodo fluidizado e garantir um bom nível de mistura e por isso dispensa a recirculação do efluente.

Além disso, a organização dos microrganismos anaeróbios e sua retenção no reator (VAZOLLER, 1999) e as característica hidrodinâmicas favoráveis à formação de grânulos, possibilita elevado tempo de retenção celular. Isto faz acomodar, portanto, altas cargas orgânicas volumétricas com tempo de retenção hidráulica curto, da ordem de horas dependendo das condições operacionais e das características do afluente. Assim, é possível desvincular o tempo de retenção celular do tempo de retenção hidráulico (FORESTI, 1994).

O biogás dos reatores deve ser gerenciado por impactos ambientais-climáticos que eles podem provocar, para controle de odores e também por questões de segurança, já que se trata de um gás combustível com risco de explosões. Por esta razão, mesmo em plantas que possuem aproveitamento energético, é utilizado equipamento para combustão direta, sem recuperação de energia, para evitar acidentes. A combustão é realizada por meio de queimadores, que são, basicamente, dispositivos que possibilitam a ignição e a destruição parcial ou completa dos gases para evitar a emissão de metano e de sulfato de hidrogênio $\left(\mathrm{H}_{2} \mathrm{~S}\right)$ causador de odor, conforme recomendado mundialmente (EUROPEAN COMMISSION, 2001).

Segundo Lobato (2011) os queimadores mais utilizados no Brasil são os abertos e, até o momento, o seu uso ainda é opcional e voluntário; ele é mais simples e apresenta um custo bem mais reduzido, quando comparado a outras tecnologias. Há apenas um queimador acoplado a um defletor de vento para proteger a chama. No entanto, trata-se de um mecanismo ineficiente, com perda de calor e formação de subprodutos indesejáveis, não atendendo a critérios de desempenho e de emissões. Por este motivo são instalados 5 a 6 metros acima do nível do terreno, por introduzir um risco adicional ou perturbações que precisam ser consideradas (IEA, 2000).

Os queimadores fechados possibilitam a combustão de biogás no interior de uma câmara de material refratário assentada sobre o terreno e permitem uma combustão mais controlada e consequentemente a redução de emissões e aumento na eficiência da destruição de gases. É capaz de atender os padrões de desempenho e de emissões. No entanto, apresentam custos até $70 \%$ maiores que os queimadores abertos. Por esse motivo são poucos utilizados no Brasil (IEA, 2000). 


\subsection{Produção do biogás}

O biogás é uma mistura gasosa combustível, resultante da digestão anaeróbia, processo fermentativo de remoção de matéria orgânica de um material. Durante este processo pode ocorrer ainda a produção de biofertilizantes ricos em nutrientes e que, desde que satisfeitas as condições da Resolução CONAMA 375/2006, podem ser utilizados na agricultura.

A produção de biogás ocorre espontaneamente na natureza, como nos pântanos, e também a partir de diversos resíduos orgânicos, como estercos de animais, lodo de esgoto, lixo doméstico, resíduos agrícolas, efluentes industriais e plantas aquáticas. Quando a digestão anaeróbia é realizada em ambientes controlados, como em biodigestores, a mistura gasosa produzida pode ser utilizada como combustível, o qual, além de seu alto poder calorífico é uma ótima alternativa para o aproveitamento de resíduos ou efluentes orgânicos (PECORA, 2006).

Segundo Noyola, Morgan-Sagastume e López-Hernandez (2006), o biogás de reatores que tratam esgoto doméstico apresenta em sua composição majoritariamente metano (70 a $80 \%$ ) v/v, nitrogênio (10 a 25\%) v/v, devido à parcela de $\mathrm{N}_{2}$ dissolvida no esgoto doméstico, e dióxido de carbono (5 a 10\%) v/v.

O processo de biodigestão foi utilizado de forma mais intensiva com finalidade energética na Índia e China nas décadas de 1950 e 1960. No Brasil ele apareceu com a crise do petróleo na década de 1970, quando foram implantados vários programas de difusão dos biodigestores, porém os estudos não geraram resultados satisfatórios e não foram suficientes para dar continuidade ao programa (PECORA, 2006). Desde então, foi tratado apenas como um subproduto, obtido a partir da decomposição anaeróbia dos resíduos domésticos e lodo proveniente de ETEs e também na zona rural, a partir dos dejetos dos animais, em especial os suínos. Com a instabilidade econômica dos preços dos combustíveis convencionais, os estudos relativos à produção de energia a partir de novas fontes alternativas e economicamente atrativas são sempre uma possibilidade de redução do uso dos recursos naturais esgotáveis.

A digestão anaeróbia é um processo, no qual diferentes espécies de bactérias, que atuam na ausência de oxigênio, atacam a estrutura de materiais orgânicos complexos, por meio de uma cadeia de degradações sucessivas, para produzir compostos simples, como o 
metano e o dióxido de carbono, deixando na solução aquosa subprodutos como amônia, sulfetos e fosfatos enquanto se alimenta de energia e compostos necessários para seu próprio crescimento (COSTA, 2006). Esse processo ocorre em duas fases diferentes. Na primeira fase, há a transformação das moléculas orgânicas em ácidos graxos, sais ou gás. A segunda é a transformação desses em uma mistura gasosa essencialmente constituída por metano e dióxido de carbono (FORESTI et al, 1999). Estas etapas são constituídas de reações sequenciais, cada uma com sua população bacteriana específica. A Figura 4 ilustra este processo de digestão anaeróbia, conforme apresentado por Chernicharo (2007).

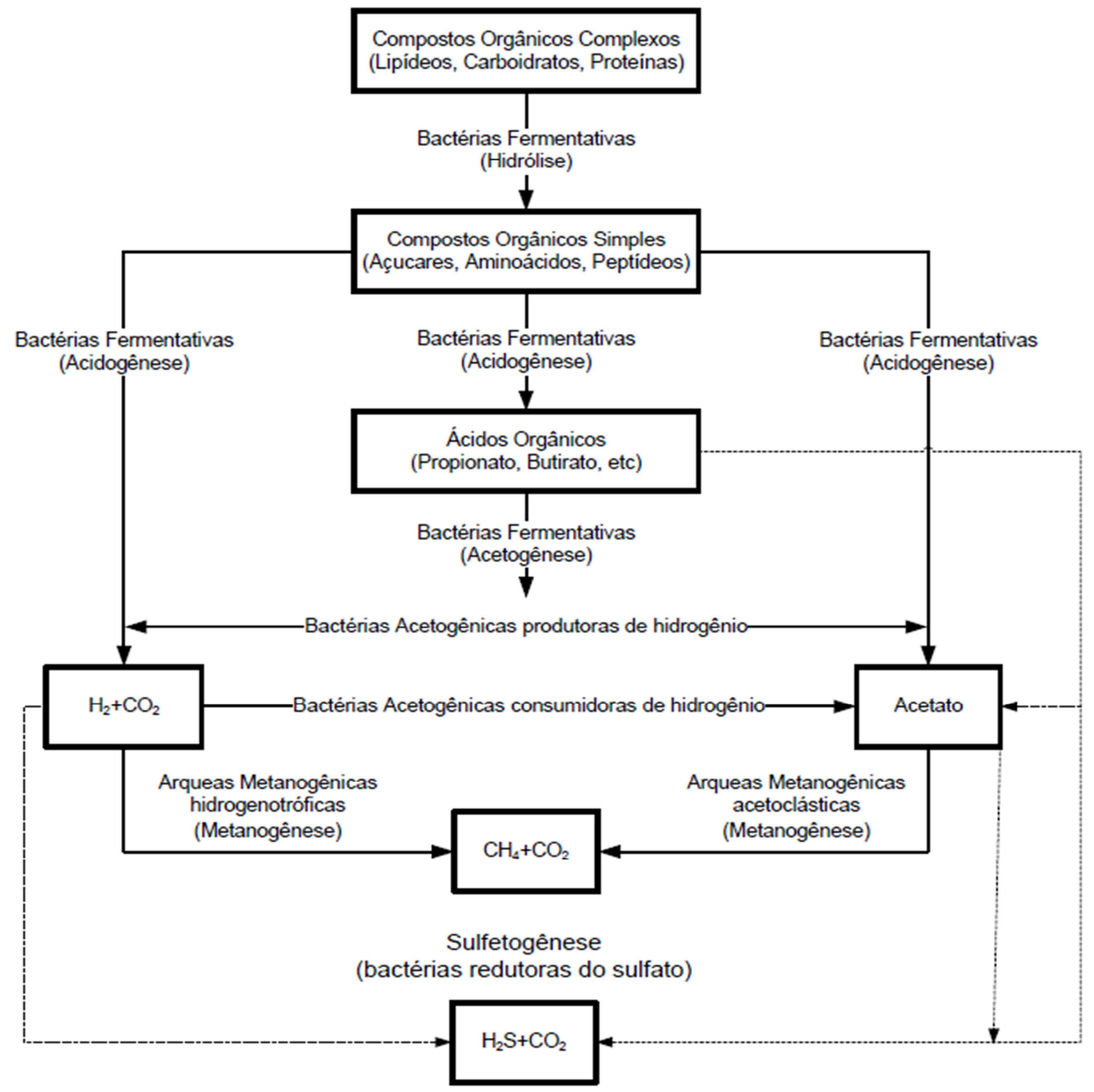

Figura 4 - Sequências metabólicas de digestão anaeróbia

Fonte: Adaptado de Chernicharo (2007). 
Durante a degradação anaeróbia da matéria orgânica em um ambiente em que a disponibilidade dos elétrons inorgânicos receptores é limitante, o material orgânico serve para ambos como elétron doador e elétron receptor, resultando na produção de dióxido de carbono $\left(\mathrm{CO}_{2}\right)$ e metano $\left(\mathrm{CH}_{4}\right)$.

2.2.1 Fatores que influenciam a produção de biogás

Segundo Pecora (2006) os principais parâmetros da digestão anaeróbia que influenciam diretamente a atividade enzimática relacionados à geração de biogás são:

- Impermeabilidade ao ar

As bactérias metanogênicas são essencialmente anaeróbias. A decomposição de matéria orgânica na presença de ar (oxigênio) irá produzir apenas dióxido de carbono $\left(\mathrm{CO}_{2}\right)$.

- Natureza do substrato

Os microrganismos são alimentados por meio dos substratos nutritivos que devem prover particularmente os oligo-elementos ${ }^{1}$, como o cálcio, magnésio, potássio, sódio, zinco, ferro, cobalto, cobre, molibdênio e manganês. No entanto, em fortes concentrações, esses elementos têm um efeito inibidor sobre o processo de fermentação. Por outro lado, os elementos majoritários (carbono, nitrogênio, oxigênio, fósforo e enxofre) têm uma importância fundamental no rendimento dos gases de fermentação.

- Composição dos resíduos

Quanto maior é a porcentagem de material orgânico no resíduo, maiores são o potencial de geração de metano e a vazão de biogás. Os principais nutrientes (substrato) dos micro-organismos são carbono, nitrogênio e sais orgânicos. Uma relação específica de carbono para nitrogênio deve ser mantida entre 20:1 e 30:1, pois influência a eficácia do sistema. A principal fonte de nitrogênio está nos dejetos humanas e de animais, enquanto os polímeros presentes nos restos de culturas representam o principal fornecedor de carbono. A produção de biogás não é bem sucedida, se apenas uma fonte de material for utilizada. Abaixo

\footnotetext{
${ }^{1}$ Oligo-elementos: elementos minerais que em fracas doses são indispensáveis às reações enzimáticas.
} 
desses valores pode ocorrer a interrupção da fermentação e acima pode atingir os limites de toxicidade.

- Temperatura

Dela advém o compromisso entre o volume de gás a produzir, o grau de fermentação e o tempo de retenção. A atividade enzimática das bactérias depende estritamente da temperatura, visto que é conhecido que alterações bruscas de temperatura causam desequilíbrio nas culturas envolvidas, principalmente nas bactérias formadoras de metano. Em torno de $10{ }^{\circ} \mathrm{C}$ esta atividade é muito reduzida e acima de $65{ }^{\circ} \mathrm{C}$ as enzimas são destruídas pelo calor. Portanto, a faixa ideal para a produção de biogás é de 32 a $37{ }^{\circ} \mathrm{C}$ (bactérias mesofílicas) e de 50 a $60^{\circ} \mathrm{C}$ (bactérias termofílicas).

- Potencial hidrogeniônico $(\mathrm{pH})$

$\mathrm{O}$ pH é calculado a partir da concentração de íons hidrogénio $(\mathrm{H}+)$ em uma solução e indica a acidez, neutralidade ou alcalinidade de uma solução aquosa. Matematicamente, o "p" equivale ao simétrico do logaritmo (cologaritmo) de base 10 da atividade dos íons a que se refere. Para íons $\mathrm{H}+\left(\right.$ Sendo que $\mathrm{H}^{+}$representa a atividade em $\mathrm{mol} \mathrm{dm}{ }^{-3}$ ) (ANDRADE, 2010):

$$
\mathrm{pH}=-\log _{10}\left[H^{+}\right]
$$

Em soluções diluídas (abaixo de $0,1 \mathrm{~mol} \mathrm{dm}^{-3}$ ), os valores da atividade se aproximam dos valores da concentração, permitindo que a equação anterior seja escrita como abaixo, onde $\mathrm{H}^{+}$é a concentração de íons hidrogênio (ANDRADE, 2010):

$$
\mathrm{pH}=-\log _{10}\left[H^{+}\right]
$$

A partir do valor do $\mathrm{pH}$ descobre-se o grau de acidez ou basicidade/alcalinidade dessa mesma solução. A concentração em íons hidroxila ou oxidrila ( $\mathrm{OH}-)$ no meio exterior tem uma grande influência sobre o crescimento dos microrganismos. Na digestão anaeróbia, observam-se duas fases sucessivas: a primeira se caracteriza por uma diminuição do pH em patamares próximos de 5,0 e a segunda por um aumento do $\mathrm{pH}$ e sua estabilização em valores próximos da neutralidade. A redução do $\mathrm{pH}$ é devida à ação das bactérias acidogênicas, as quais liberam rapidamente ácidos graxos voláteis. As bactérias metanogênicas (que têm taxas de crescimento mais fracas que as primeiras) se instalam progressivamente e induzem a elevação do pH por meio da catálise do ácido acético. No caso de tratamento anaeróbio em biodigestores (processos contínuos), o $\mathrm{pH}$ permanece neutro $(\mathrm{pH} \sim 7) . \mathrm{O} \mathrm{pH}$ do meio, quando ácido, anula a atividade enzimática e, quando alcalino, produz anidrido sulforoso e hidrogena, sendo que o pH neutro é o mais indicado. 
- Materiais tóxicos

Por fim, as matérias tóxicas, detergente e outros produtos que mesmo em pequenas concentrações podem provocar a intoxicação e morte das bactérias (COSTA, 2006).

\subsubsection{Propriedades físicas e químicas do biogás}

Apesar de o biogás ser majoritariamente constituído por metano, é necessário conhecer ainda os elementos presentes em menores quantidades, visto que eles influenciam diretamente na escolha da tecnologia de operação, limpeza e combustão.

A Tabela 2 mostra algumas das propriedades físicas do metano, gás carbônico e gás sulfídrico.

Tabela 2 - Propriedades físicas do metano, gás carbônico e gás sulfídrico.

\begin{tabular}{|c|c|c|c|}
\hline Propriedade & Metano $\left(\mathrm{CH}_{4}\right)$ & $\begin{array}{l}\text { Dióxido de Carbono } \\
\qquad\left(\mathrm{CO}_{2}\right)\end{array}$ & Gás sulfídrico $\left(\mathrm{H}_{2} \mathrm{~S}\right)$ \\
\hline Peso molecular & 16,04 & 44,01 & 34,08 \\
\hline $\begin{array}{l}\text { Peso Específico } \\
\qquad(\mathrm{Ar}=1)\end{array}$ & $0,555^{\text {(a) }}$ & $1,52^{\text {(a) }}$ & $1,189^{(b)}$ \\
\hline Volume específico & $1473,3 \mathrm{~cm}^{3} / \mathrm{g}^{\text {(a) }}$ & $543,1 \mathrm{~cm} 3 / \mathrm{g}^{(\mathrm{b})}$ & $699,2 \mathrm{~cm} 3 / \mathrm{g}^{(\mathrm{b})}$ \\
\hline $\begin{array}{c}\text { Capacidade calorífica } \\
\qquad \mathrm{Cp}, \text { a } 1 \mathrm{~atm}\end{array}$ & $0,775 \mathrm{kcal} / \mathrm{kg}^{\circ} \mathrm{C}^{(\mathrm{a})}$ & $0,298 \mathrm{kcal} / \mathrm{kg}^{\circ} \mathrm{C}^{(\mathrm{c})}$ & $0,372 \mathrm{kcal} / \mathrm{kg}^{\circ} \mathrm{C}^{(\mathrm{c})}$ \\
\hline Relação, CP/CV & 1,307 & 1,303 & 1,32 \\
\hline $\begin{array}{l}\text { Poder calorífico } \\
\text { superior }\end{array}$ & $13,268 \mathrm{kcal} / \mathrm{kg}$ & $0 \mathrm{kcal} / \mathrm{kg}$ & $4,633 \mathrm{kcal} / \mathrm{kg}$ \\
\hline $\begin{array}{l}\text { Limite de } \\
\text { inflamabilidade }\end{array}$ & $5-15 \%$ por volume & nenhum & $4-46 \%$ por volume \\
\hline
\end{tabular}

Obs: (a): $60^{\circ} \mathrm{C}, 1 \mathrm{~atm} ;$ (b): $70^{\circ} \mathrm{C}, 1 \mathrm{~atm} ;(\mathrm{c}): 77^{\circ} \mathrm{C}, 1 \mathrm{~atm}$.

Fonte: Ross e Drake (1996).

O elemento mais combustível do biogás é o metano e a presença de outros elementos pode prejudicar o processo por absorverem parte da energia gerada, ou seja, à medida que se eleva a quantidade de impurezas o poder calorífico do biogás fica menor. 
Considerando os fatores que influenciam a geração de biogás, em especial a temperatura, a pressão e o teor de umidade, torna-se fundamental conhecer seu volume, umidade e poder calorífico antes da proposição de uso energético.

Segundo Ross e Drake (1996), a relação entre o peso específico e a concentração do metano é inversamente proporcional e segundo Alves (2000) a porcentagem em volume de metano presente no biogás é diretamente proporcional ao poder calorífico. Pecora (2006) aponta que o volume de biogás é representado pelo peso específico (relação entre a sua densidade e a densidade do ar). Este fator torna-se importante para manipular o gás para armazenamento.

A umidade, por sua vez, tem influência direta no processo de combustão, afetando a temperatura de chama, limites de inflamabilidade, diminuição do poder calorífico e taxa arcombustível do biogás (PECORA, 2006).

Analisando a composição típica de biogás gerado em reatores anaeróbio tratando esgoto doméstico (Tabela 3), conclui-se que o menor teor de $\mathrm{CO}_{2}$ no biogás de reatores UASB indica que a maior parte desse gás permanece no efluente como íons bicarbonato (AGRAWAL, HARADA e OKUI, 1997).

Tabela 3 - Composição típica do biogás gerado em reatores anaeróbios tratando esgoto doméstico.

\begin{tabular}{ccc}
\hline Parâmetro & Unidade & Composição volumétrica típica \\
\hline Metano - $\mathrm{CH}_{4}$ & $\%$ & 60 a 85 \\
Gás Carbônico - $\mathrm{CO}_{2}$ & $\%$ & 5 a 15 \\
Monoxido de carbono - $\mathrm{CO}$ & $\%$ & 0 a 0,3 \\
Nitrogênio - $\mathrm{N}_{2}$ & $\%$ & 10 a 25 \\
Hidrogênio $-\mathrm{H}_{2}$ & $\%$ & 0 a 3 \\
Gás sulfidrico $-\mathrm{H}_{2} \mathrm{~S}$ & ppmv & 1000 a 2000 \\
Oxigênio $-\mathrm{O}_{2}$ & $\%$ & traços
\end{tabular}

Fonte: adaptado de NOYOLA; CAPDEVILLE; ROQUES. (1988); NOYOLA; MORGAN-SAGASTUME; LOPEZ-HERNANDEZ. (2006).

Com relação ao poder calorífico, segundo Coelho et al (2001), o biogás bruto tem cerca de $21.600 \mathrm{~kJ} / \mathrm{Nm}^{3}$, em condições normais de temperatura e pressão $(\mathrm{CNTP}): \mathrm{T}=0$ e $\mathrm{P}=$ $1 \mathrm{~atm}$, o equivalente a aproximadamente meio litro de óleo diesel, enquanto o poder calorífico do biogás purificado é de cerca de $34.200 \mathrm{~kJ} / \mathrm{Nm}^{3}$. No entanto a eficiência do aproveitamento depende dos equipamentos empregados no aproveitamento energético visto que existem 
diversos equipamentos tanto para combustão ou geração combinada de eletricidade e calor, e estes equipamento possuem eficiências diferentes. 


\section{APROVEITAMENTO ENERGÉTICO DO BIOGÁS}

O aproveitamento com recuperação de energia do biogás pode se dar por meio da combustão ou, da geração combinada de eletricidade e de calor.

A combustão direta pode ocorrer por meio de caldeiras. Nesse caso, o biogás é utilizado como combustível e sua energia é transferida para o fluído de trabalho (água que é vaporizada na caldeira) contido no interior de uma câmara fechada, e daí até o ponto de utilização final. Esta prática permite a substituição de um combustível convencional pelo biogás e é amplamente conhecida e com histórico de sucesso nos Estados Unidos da América (EUA) e na Europa há mais de 25 anos (LOBATO, 2011). A combustão direta do biogás em caldeiras é bastante similar à queima de gás natural diluído. Para o adequado funcionamento do sistema quando operado exclusivamente com o biogás são necessárias algumas modificações para compensar o menor conteúdo energético do biogás, que deverá ser utilizado em maior volume (USEPA, 2008b).

Os motores de combustão interna e as turbinas a gás são as tecnologias mais utilizadas para conversão em energia elétrica (PECORA, 2006). Os motores de combustão interna são divididos em motores de ignição por centelha ou Otto, e, de ignição por compressão ou Diesel. No caso das turbina a gás, elas podem ser dividas em microturbinas, com uma faixa de potência de até $100 \mathrm{~kW}$, e turbinas de médio e grande porte, com faixas de potências de poucas centenas de $\mathrm{kW}$ até quase $300 \mathrm{MW}$. São equipamentos constituídos por compressor, câmara de combustão e a turbina de expansão (ciclo Brayton) (COSTA, 2006).

Outra forma de aproveitamento térmico do biogás se dá como fonte de energia para a secagem térmica, que é um processo de remoção de umidade de uma matéria sólida ou líquida por meio da transferência de calor para evaporação do líquido e transferência de massa como líquido ou vapor dentro dos sólidos e como vapor para a superfície. Esta forma de aproveitamento pode ser aplicada na própria ETE, por meio da secagem térmica do lodo, que promove a redução da umidade e a destruição dos organismos patogênicos (PERRY E GREEN, 1997).

A secagem térmica pode ser classificada em direta ou indireta. Os secadores diretos atuam por meio de contado direto dos gases quentes com os sólidos, atingindo temperaturas de até $750^{\circ} \mathrm{C}$. A eficiência aumenta com o aumento da temperatura do gás afluente, e devido à necessidade de grandes volumes de gás para fornecer todo o calor. 
Os secadores indiretos, o calor é transferido ao material úmido mediante a condução numa parede metálica, com temperaturas médias de $540{ }^{\circ} \mathrm{C}$ e são convenientes para permitir a recuperação de solventes e impedir a ocorrência de misturas explosivas ou a oxidação de materiais que se decompõem com facilidade.

Por sua vez, a geração combinada de energia elétrica e térmica ou cogeração consiste no aproveitamento, para uma aplicação secundária, do calor residual sob a forma de vapor, água quente e/ou fria, originado nos processos termodinâmicos de geração de energia elétrica, que de outra forma seria desperdiçado. O calor poderia ser utilizado para secagem de lodo, por exemplo. Isto torna o processo mais eficiente, visto que a maior parte da energia contida nesse combustível é transformada em calor e perdida para o meio ambiente durante a geração de eletricidade.

3.1 Principais tecnologias disponíveis para conversão energética do biogás

Várias tecnologias de geração e cogeração de energia estão bem desenvolvidas e suficientemente comprovadas com diversos sistemas disponíveis, cobrindo os diferentes combustíveis e uma vasta gama de potências. Para o aproveitamento do biogás é necessário converter a energia química contida em suas moléculas em energia mecânica por um processo de combustão controlada. Essa energia mecânica ativa um alternador que a converte em energia elétrica. Quando queimado direto em caldeiras o biogás poder ser utilizado para energia térmica, geração de eletricidade por meio de turbinas a vapor em ciclos Rankine ou sistemas de cogeração, como discutido a seguir.

Ainda existem tecnologias promissoras sendo aperfeiçoadas, como é o caso da célula combustível (COSTA, 2006; PECORA, 2006). Os equipamentos disponíveis no mercado para geração de energia elétrica utilizando biogás foram fabricados visando o aproveitamento dos dejetos de animais. Para aplicação em esgotos é necessário verificar o teor de metano da matéria orgânica e, a partir de então, selecionar a potência adequada, a fim de obter a melhor eficiência do gerador. 


\subsubsection{Motores de combustão interna}

Os motores de combustão interna (Figura 5) são máquinas que transformam a energia térmica de um combustível em energia mecânica por meio do acionamento de pistões confinados em cilindros, sendo os ciclos de operação do tipo Otto e Diesel os mais comumente utilizados (COSTA, 2006). A diferença básica entre eles está na forma em que ocorre a combustão. Segundo França Jr. (2008), o aproveitamento do calor ocorre com a utilização da energia contida nos gases de exaustão e/ou nos fluidos de refrigeração e lubrificação. A quantidade de calor recuperada depende do tipo e porte do motor e de seu regime operacional. O calor que precisa ser rejeitado dos óleos lubrificantes e do fluido de refrigeração é limitado à produção de água quente. Já os gases de escape podem ser aproveitados diretamente ou serem conduzidos à caldeira de recuperação para gerar vapor. Ambos os ciclos são largamente utilizados em transportes, sendo que motor a diesel é projetado para ser mais pesado e mais potente do que os motores a gasolina e utiliza óleo como combustível. Seu rendimento é função apenas da relação de compressão (VAN WYLEN, 1998). Para gerar energia elétrica é necessário o acoplamento de um gerador ao motor e para geração de energia mecânica pode ser empregada um bomba hidráulica.

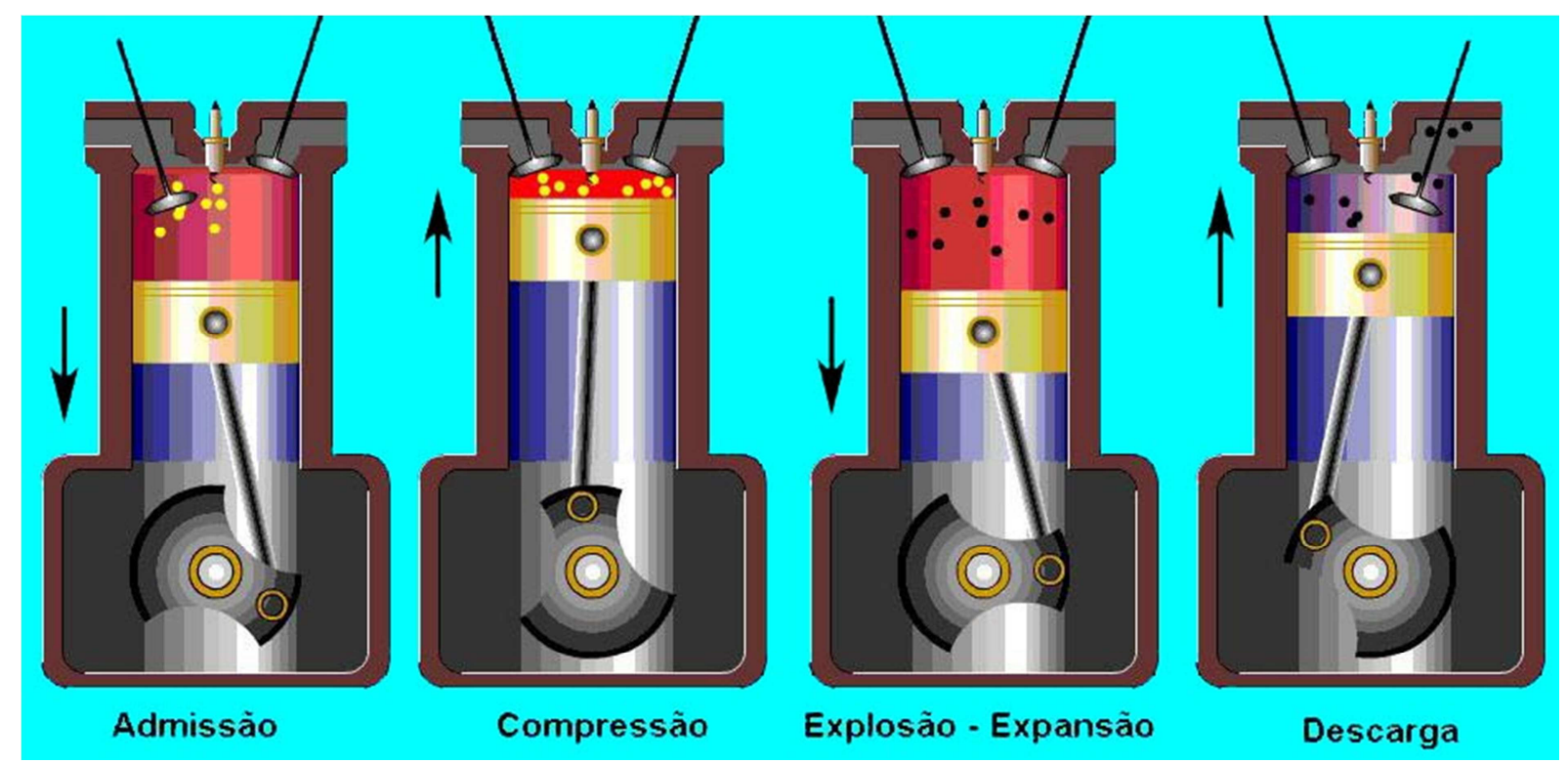

Figura 5 - Moto de combustão interna.

Fonte: SILVEIRA, 2010. 
No ciclo Diesel, a combustão ocorre pela compressão do combustível na câmara de combustão, enquanto no ciclo Otto, a combustão ocorre pela explosão do combustível por meio de uma fagulha na câmara de combustão. O ciclo Otto consiste em expansão/resfriamento adiabático, seguido de resfriamento a volume constante, aquecimento/compressão adiabático e aquecimento a volume constante. A válvula de entrada de ar abre no tempo preciso para permitir a entrada de ar (misturado ao combustível) no cilindro. A vela dá ignição na mistura no cilindro, o que cria a explosão. A força da explosão é transferida ao pistão. O pistão desce e sobe em um movimento periódico. A força do pistão é transferida por meio da manivela para o eixo de transmissão (VAN WYLEN, 1998).

Segundo França Jr. (2008), os motores de combustão interna podem utilizar combustíveis gasosos, líquidos e ainda misturas de combustíveis gasosos com líquidos em proporções que permitam a auto-ignição. No entanto, para utilização de biogás o ciclo Otto é o mais recomendável. Para utilizar o gás em equipamentos de ciclo Diesel é necessário que o combustível inserido na câmara de combustão seja uma mistura de gás com 3 a $5 \%$ de diesel. Esses equipamentos são conhecidos como bi-fuel ou dual-fuel, em função do modo em que são executadas as misturas de combustíveis.

As principais vantagens da cogeração de energia por meio de motores a gás são as seguintes:

- Arranque rápido;

- Fácil adaptação a variações das necessidades térmicas;

- Elevada eficiência mecânica;

- Não necessita de vigilância constante.

Já as principais desvantagens da cogeração de energia por meio de motores a gás são resumidas a tempo de vida útil curto, baixo rendimento térmico e elevados custos de manutenção devido à necessidade de paradas frequentes.

Ambos os motores podem ser úteis para o setor terciário e em pequenas indústrias/empresas, bem como em sistemas de produção de energia de emergência e em locais isolados. De forma geral, o seu uso é mais recomendado em situações nas quais as necessidades térmicas sejam pouco significativas ou quando os consumos de energia sofrem variações ao longo do tempo.

A adaptação de motores de ciclo Otto para motores a biogás é relativamente fácil. No entanto, Pecora (2006) demonstrou que esse processo é impactante em termos de emissão atmosférica, podendo emitir de 250 a 3000 ppm (partes por milhão) de $\mathrm{NO}_{\mathrm{x}}$, valor que pode 
ser até 60 vezes maior que o emitido por meio turbinas a gás cujo principal impacto é a formação de ozônio troposférico.

Há ainda os motores de ciclo Brayton, ciclo no qual o ar é succionado constantemente pelo compressor onde é comprimido para alta pressão e enviado à câmara de combustão, onde é misturado com o combustível e surgem gases a altas temperaturas, que são encaminhados à turbina onde são expandidos e descarregados na atmosfera, gerando trabalho mecânico. $\mathrm{O}$ eixo da turbina é conectado ao compressor e ao gerador elétrico, de maneira que o trabalho mecânico gerado pela expansão dos gases de combustão aciona tanto o compressor gerador elétrico e um dispositivo mecânico (VAN WYLEN, 1998).

O rendimento do ciclo Brayton é de aproximadamente 35\%, mas, segundo Pecora (2006) há turbinas, como a LM6000 de 46.000 kW da G.E. (General Electric), por exemplo, que possuem um rendimento de $41,9 \%$.

A cogeração neste ciclo é obtida por meio da adição ao ciclo de uma caldeira de recuperação de calor. Nesse caso, os gases de exaustão da turbina são direcionados para a caldeira, de modo a gerar vapor. Este vapor é, então, utilizado no processo industrial.

\subsubsection{Turbinas a gás adaptadas para biogás}

As turbinas a gás são equipamentos térmicos que realizam a conversão de energia de um combustível em potência utilizando como fluido de trabalho os gases de combustão da turbina. São formadas por compressor de ar, uma câmara de combustão e a turbina (a gás) propriamente dita.

A própria turbina aciona o compressor que comprime e eleva a pressão do ar. Em seguida o ar é misturado ao combustível na câmara de combustão e essa mistura é queimada sob uma condição de pressão constante, em regime contínuo, aumentando a temperatura dos gases e introduzindo, dessa forma, a energia primária no sistema (FRANÇA JR, 2008). O gás resultante é expandido na turbina, de onde se extrai a energia mecânica para acionamento do compressor e da carga acoplada ao eixo (Figura 6). Nas turbinas usadas em aviões a jato, os gases quentes são exauridos por meio de bocais que transformam a energia dos gases do empuxo. 


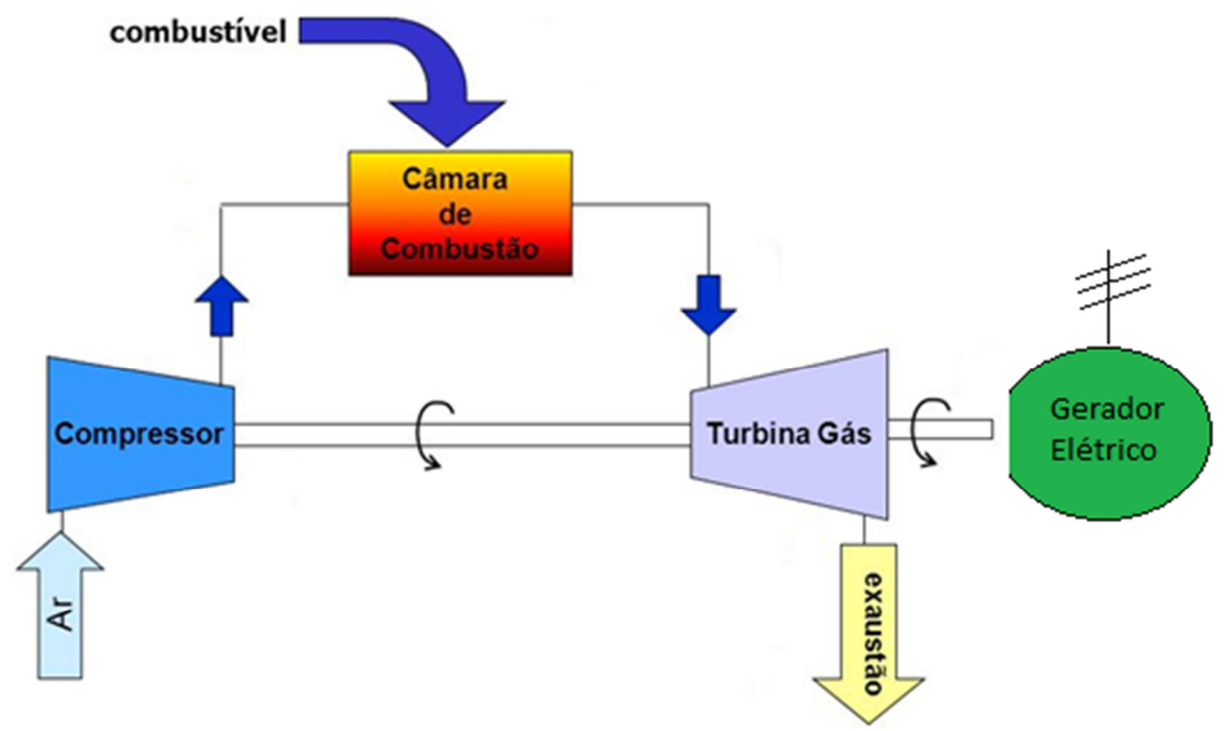

Figura 6 - Fluxograma para turbinas à gás.

Fonte: Adapto de França Jr. (2008).

Por razões de limitação de temperatura suportável pelos materiais utilizados na construção das turbinas, a massa de ar injetada na câmara da combustão é muito superior a quantidade requerida para e estabelecer a reação estequiométrica da combustão. Assim, os gases de exaustão da turbina contêm ainda uma quantidade significativa de oxigênio. Quanto mais elevada for a temperatura e a pressão dos gases na entrada do primeiro estágio da turbina, e quanto mais reduzida for a temperatura dos gases de exaustão, maior será a eficiência da turbina a gás (ODDONE, 2001).

As principais características deste equipamento são a produção de gases de exaustão em grandes volumes e a temperaturas elevadas, o que melhora o rendimento térmico do conjunto, permite unidades mais compactas. Além disso, possuem fácil manutenção e controle podendo ser automatizadas.

Os combustíveis (líquidos ou gasosos), por sua vez, devem ser extremamente limpos de modo a não danificar os bicos injetores e possuir características como:

- Não formar cinzas na combustão, que se depositam nas palhetas das turbinas e interferem na operação;

- Não conter materiais erosivos;

- Não conter compostos que provoquem corrosão das palhetas das turbinas.

O processo será tão mais eficiente quanto maior forem a temperatura e a pressão de entrada e menor for a temperatura de exaustão. Segundo Lautman (1993), o fator de 
disponibilidade $^{2}$ destas turbinas é maior que $90 \%$, além de entrar em funcionamento com rapidez. Segundo a ANEEL (1998), o tempo para uma turbina atingir a plena carga é de 15 minutos em condições normais.

A evolução tecnológica dos fatores que afetam estes parâmetros tem promovido, nos últimos anos, o contínuo aperfeiçoamento dessas máquinas (COSTA, 2006). Nesse sentido, há modelos adaptados para a geração com biogás como os da Solar Turbines do Grupo Caterpillar (VAN WYLEN, 1998). As turbinas a gás podem ser divididas em microturbinas, com uma faixa de potência de até $200 \mathrm{~kW}$, como as turbinas a biogás estudadas no âmbito do projeto ENER-BIOG com potência de $30 \mathrm{~kW}$ (PECORA, 2006) e mais recentemente microturbinas de $200 \mathrm{~kW}$ utilizadas para geração de energia na ETE Arrudas, em Belo Horizonte - Minas Gerais; e turbinas de médio e grande porte, com faixas de potências de poucas centenas de $\mathrm{kW}$ até quase $300 \mathrm{MW}$.

\subsubsection{Microturbinas a gás}

O termo "microturbina" refere-se a um sistema de geração de energia de dimensões reduzidas, derivadas da tecnologia utilizada nas Airborne Power Unit (APU's), operando com ciclo Brayton, composto por: compressor, câmara de combustão, turbina e gerador elétrico de potência inferior a $200-250 \mathrm{~kW}$, com elevadas velocidades de rotação e possibilidade de utilizar diversos tipos de combustível, como gás natural, biogás, GLP (gás liquefeito de petróleo), gás de poços de petróleo, diesel, "gas oil" e querosene. Permite ainda funcionar em cogeração utilizando equipamento adicional, permitindo reduzir o consumo de energia primária, em comparação à geração típica de calor e eletricidade (FRANÇA JR, 2008).

Nas microturbinas o ar aspirado pelo compressor tem sua pressão elevada e é comprimido seguindo para a câmara de combustão onde o combustível é injetado e misturado ao ar. O processo de queima é controlado para se obter a máxima eficiência e baixos níveis de emissão. Os gases aquecidos em alta pressão são forçados para o interior da turbina a alta velocidade, sofrendo expansão nas palhetas da turbina fazendo com que essa gire em alta

\footnotetext{
2 Fator de diponibilidade é um indicador para medir perdas por paradas não planejadas.
} 
velocidade e produza trabalho. Os gases não aproveitados são exauridos para a atmosfera. No mesmo eixo do compressor é montada a turbina de expansão e o gerador elétrico. A turbina de expansão é responsável por fornecer a energia necessária para girar o compressor e o gerador elétrico (ciclo completo). Referindo-se a sistemas estacionários, os gases, depois da expansão na turbina, ainda contém uma grande quantidade de energia térmica que pode ser utilizada em trocadores de calor para produzir frio ou vapor de processo, dependendo do sistema, caracterizando um ciclo de cogeração (FRANÇA JR., 2008).

Para utilização do biogás gerado em ETE, que geralmente está a uma pressão muito baixa, é necessária a adição de um compressor ao conjunto, quando a pressão de alimentação do combustível não for suficiente.

França Jr (2008) destaca as vantagens da utilização de um sistema de microturbina para geração de energia:

- Fácil manutenção, implicando menores tempos de parada;

- Arranque relativamente rápido;

- Grande confiabilidade;

- Sistema compacto e relativamente isento de vibrações, exigindo menos despesas em termos de estruturas, fundações e isolamentos acústicos;

- Não necessita de vigilância constante;

- Disponibilidade de energia térmica a temperaturas elevadas;

- Redução significativa da emissão de poluentes e particularmente do NOx (9 ppm apenas nas turbinas da Capstone).

Enquanto as desvantagens desse sistema podem ser resumidas ao uso menos atrativo em processos com poucas necessidades térmicas, necessidade de remoção de siloxanos, tempo de vida útil relativamente curto e ainda os custo elevados quando comparados aos grupos geradores (CENBIO, 2004).

Algumas características das tecnologias disponíveis comercialmente são descritas na Tabela 4:

Tabela 4 - Características das tecnologias Comerciais

\begin{tabular}{cccc}
\hline & Potência & Rendimento & Emissão de $\mathrm{NO}_{\mathrm{x}}$ \\
\hline Motores a Gás & $30 \mathrm{~kW}-20 \mathrm{MW}$ & $30 \%-40 \%$ & $250 \mathrm{ppm}-3.000 \mathrm{ppm}$ \\
Turbinas a Gás & $500 \mathrm{~kW}-150 \mathrm{MW}$ & $20 \%-30 \%$ & $35 \mathrm{ppm}-50 \mathrm{ppm}$ \\
Microturbinas a Gás & $30 \mathrm{~kW}-100 \mathrm{~kW}$ & $24 \%-28 \%$ & $<9 \mathrm{ppm}$ \\
\hline
\end{tabular}

Fonte: CENBIO, 2003. 


\subsection{Requisitos de tratamento do biogás}

Antes de escolher a tecnologia de conversão é necessário prever quais as adaptações serão necessárias para o emprego do biogás, e seja qual for o uso pretendido, haverá sempre a necessidade de algum tipo de tratamento. Para isso é necessário observar propriedades como pressão, contaminantes, gases inertes e, principalmente, presença de umidade e gases ácidos, sendo estes responsáveis por corrosão precoce dos equipamentos e emissões indesejadas de poluentes.

A presença de umidade é responsável pela formação de condensado, que é formado devido à diferença de temperatura entre o interior do reator (temperaturas mais altas) e o interior do sistema de coleta devido à perda de calor ao longo da tubulação de transporte e pode bloquear o sistema de coleta e interromper o processo de recuperação de energia. A umidade pode ser controlado a partir da utilização de declividades adequadas para as tubulações, de modo a permitir sua drenagem para o interior do reator ou para pontos de purga (USEPA, 1996). Nas turbinas a gás, o efeito do condensado é mais crítico (COSTA, 2006).

O sulfeto de hidrogênio e os compostos orgânicos halogenados são as substâncias que representam a maior ameaça à segurança da utilização do biogás. Os hidrocarbonetos fluorados ou clorados também devem receber atenção especial, pois podem propiciar a formação de dioxinas e furanos se as condições do processo não forem satisfatórias, e oferecem o risco de corrosão pela condensação de substâncias combustíveis e consequente formação de ácidos no equipamento (dano semelhante ao ocasionado pelo $\mathrm{H}_{2} \mathrm{~S}$ ) (DWA, 2010). Segundo Glória (2009), além dessa substância ser o principal causador de odor nas ETEs, outro problema comumente associados é a corrosão das estruturas físicas dos reatores anaeróbios. A queima do $\mathrm{H}_{2} \mathrm{~S}$, por sua vez, gera óxidos de enxofre $\left(\mathrm{SO}_{3}\right.$ e $\left.\mathrm{SO}_{2}\right)$, gases extremamente poluentes para a atmosfera, pois o $\mathrm{SO}_{2}$ reage com a água e outros gases da atmosfera e provocando a chuva ácida.

São poucos os métodos apropriados para a remoção seletiva do $\mathrm{H}_{2} \mathrm{~S}$ e de outros compostos de enxofre, sem que removam, também, o metano (BARBOSA e STUETZ, 2005). Segundo Holm-Nielse, Al Seadi e Oleskowicz-Popiel. (2009), o gás sulfídrico em níveis 
superiores a 300-500 ppm, podem causar danos as técnicas de conversão energética, devido ao seu caráter altamente corrosivo.

Em alguns casos o biogás pode conter siloxanos ${ }^{3}$, formados a partir da degradação anaeróbia de materiais comumente encontrados em cosméticos, desodorantes, aditivos de alimentos e alguns sabões. Durante a combustão de biogás contendo siloxanos, pode ocorrer a formação de depósitos contendo sílica $\left(\mathrm{SiO}_{2}\right)$ ou silicatos $\left(\mathrm{Si}_{\mathrm{x}} \mathrm{O}_{\mathrm{y}}\right)$, e ainda cálcio, enxofre, zinco e fósforo. Esses depósitos minerais provocam incrustações com vários milímetros de espessura e devem ser removidos por meio de métodos químicos ou mecânicos (CHERNICHARO e STUETZ, 2008), principalmente no caso de turbinas a gás operando com biogás.

Segundo Costa (2006) as turbinas a gás apresentam poucos problemas de corrosão, todavia necessitam de gás com qualidade consistente e propriedades mais controladas acarretando o uso de sistemas de purificação do gás, o que não se faz necessário para motores de combustão interna, pois, além de suportar o uso de um biogás "in-natura" sem purificação, dispensa a necessidade de compressão uma vez que o seu princípio de funcionamento se dá por aspiração (Coelho et al, 2006).

Para usos menos nobres, como a combustão direta, o tratamento pode ser a simples remoção de condensado. No entanto, para evitar possíveis danos aos equipamentos pertencentes ao processo de conversão energética na utilização do biogás como combustível em motores ciclo Otto, o tratamento mínimo requerido refere-se à retirada de umidade e do gás sulfídrico $\left(\mathrm{H}_{2} \mathrm{~S}\right)$ presentes no biogás (PECORA, 2006). Para utilizações mais nobres, como combustível veicular, este tratamento pode ser bastante complexo (CHERNICHARO e STUETZ, 2008) envolvendo a retirada de $\mathrm{H}_{2} \mathrm{~S}, \mathrm{CO}_{2}$ e $\mathrm{N}_{2}$ por que reduzem o poder calorífico do biogás (BARBOSA e STUETZ, 2005). O uso do biogás em veículos necessita de adaptações, enquanto que o uso do biogás purificado (sem impurezas e sem $\mathrm{CO}_{2}$ ) pode ser usado em motores veiculares a gás natural em substituição a este combustível.

O custo do tratamento do biogás dependerá do requisito de pureza da aplicação que se pretende, sendo o custo de um filtro de gás, para remover condensados visando à produção de

${ }^{3}$ Qualquer composto químico contendo unidades na forma $\mathrm{R}_{2} \mathrm{SiO}$, onde R é um átomo de hidrogênio ou um radical orgânico. Segundo Lobato (2011), a ocorrência de siloxanos é mais comum em biogás gerado em aterros sanitários, no entanto, segundo Coelho et al (2006), a quantidade de siloxinas presente no biogás está diretamente ligada a quantidade cosméticos e produtos de higiene pessoal, principalmente pasta de dente, utilizada pela população que gera o efluente a ser tratado, tendendo a ser maior em comunidades com alto poder aquisitivo, que consomem mais estes produtos. 
energia, consideravelmente inferior ao custo da remoção de dióxido de carbono e outros constituintes, como para o caso de injeção na linha de gás natural ou para conversão em combustível veicular (USEPA, 1996).

Assim, dependendo do uso final do biogás, o sistema de limpeza a ser utilizado deve ser cuidadosamente analisado. A DWA (2010), por exemplo, sugere vários métodos e técnicas para eliminar diversos componentes durante o tratamento do biogás (Tabela 5):

Tabela 5 - Métodos de tratamento de biogás

\begin{tabular}{|c|c|c|c|}
\hline $\begin{array}{l}\text { Componente a } \\
\text { ser eliminado }\end{array}$ & Método & Técnicas & $\begin{array}{c}\text { Eliminação e } \\
\text { problemas de } \\
\text { emissões }\end{array}$ \\
\hline
\end{tabular}

Filtro de seixo, filtro fino (cartuchos)

Poeira, partículas Separação desnebulizador, separador ciclônico,

precipitador de placas, tanque vertical

\begin{tabular}{|c|c|c|c|}
\hline Vapor de água & $\begin{array}{l}\text { Arrefecimento } \\
+5{ }^{\circ} \mathrm{C} \\
\text { separação }\end{array}$ & $\begin{array}{c}\text { Máquina frigorífica, refrigerador de } \\
\text { água fria }\end{array}$ & $\begin{array}{l}\text { Eliminação } \\
\text { normalmente sem } \\
\text { dificuldades }\end{array}$ \\
\hline $\begin{array}{l}\text { Hidrocarbonetos } \\
\text { condensáveis / } \\
\text { minerais }\end{array}$ & $\begin{array}{l}\text { Compressão } \\
\text { arrefecimento/ } \\
\text { separação }\end{array}$ & $\begin{array}{l}\text { Compressor de pistão/compressor } \\
\text { parafuso }\end{array}$ & \\
\hline \multirow{3}{*}{ Amônia } & $\begin{array}{l}\text { Condensação } \\
\text { ponto de } \\
\text { orvalho }\end{array}$ & $\begin{array}{c}\text { Condensação pelo arrefecimento do } \\
\text { biogás a aprox. } 3{ }^{\circ} \mathrm{C} \text { a } 5{ }^{\circ} \mathrm{C}\end{array}$ & \multirow{3}{*}{$\begin{array}{l}\text { Equipamentos } \\
\text { externos de } \\
\text { regeneração } \\
\text { disponíveis }\end{array}$} \\
\hline & $\begin{array}{l}\text { Condensação } \\
\text { congelamento }\end{array}$ & $\begin{array}{c}\text { Condensação pelo arrefecimento do } \\
\text { biogás a aprox. }-25^{\circ} \mathrm{C}\end{array}$ & \\
\hline & $\begin{array}{l}\text { Carvão } \\
\text { ativado }\end{array}$ & $\begin{array}{c}\text { Regeneração a vapor Regeneração a } \\
\text { calor }\end{array}$ & \\
\hline Nitrogênio & $\begin{array}{l}\text { Adsorção em } \\
\text { peneira } \\
\text { molecular }\end{array}$ & $\begin{array}{l}\text { Adsorção com modulação de pressão } \\
\text { por peneira molecular de carbono }\end{array}$ & \\
\hline \multirow{3}{*}{$\begin{array}{l}\text { Sulfeto de } \\
\text { hidrogênio }\end{array}$} & $\begin{array}{c}\text { Carvão } \\
\text { ativado } \\
\text { impregnado }\end{array}$ & $\begin{array}{c}\text { Técnica de leito simples; Técnica de } \\
\text { leito duplo; Técnica de leito duplo } \\
\text { com regeneração }\end{array}$ & $\begin{array}{c}\text { A massa pode ser } \\
\text { lançada em aterro. } \\
\text { Tratamento de } \\
\text { enxofre } \\
\text { tecnicamente } \\
\text { viável }\end{array}$ \\
\hline & $\begin{array}{l}\text { Pellets com } \\
\text { óxido de ferro }\end{array}$ & $\begin{array}{c}\text { Coluna com massa de tratamento e } \\
\text { regeneração }\end{array}$ & $\begin{array}{c}\text { É permitida a } \\
\text { deposição da } \\
\text { massa em aterros } \\
\text { sanitários }\end{array}$ \\
\hline & $\begin{array}{l}\text { Oxidação } \\
\text { biológica }\end{array}$ & $\begin{array}{l}\text { Colunas de destilação fracionada, } \\
\text { biofilme, filtro biológico; Injeção de } \\
\text { oxigênio do ar no gasômetro }\end{array}$ & $\begin{array}{l}\text { Aproveitável } \\
\text { como adubo }\end{array}$ \\
\hline
\end{tabular}




\begin{tabular}{|c|c|c|c|}
\hline $\begin{array}{l}\text { Componente a } \\
\text { ser eliminado }\end{array}$ & Método & Técnicas & $\begin{array}{c}\text { Eliminação e } \\
\text { problemas de } \\
\text { emissões }\end{array}$ \\
\hline & $\begin{array}{l}\text { Lavador } \\
\text { biológico de } \\
\text { gás }\end{array}$ & $\begin{array}{l}\text { Coluna de lavagem preenchido com } \\
\text { meio suporte }\end{array}$ & $\begin{array}{l}\text { Esgoto alcalino, } \\
\text { ETE; aproveitável } \\
\text { como adubo }\end{array}$ \\
\hline & $\begin{array}{l}\text { Lavagem } \\
\text { cáustica }\end{array}$ & $\begin{array}{l}\text { Coluna de lavagem preenchido com } \\
\text { meio suporte }\end{array}$ & $\begin{array}{l}\text { aproveitável como } \\
\text { adubo }\end{array}$ \\
\hline & $\begin{array}{l}\text { Dosagem de } \\
\quad \text { ferro }\end{array}$ & Dosagem no reator & $\begin{array}{c}\text { com o } \\
\text { biofertilizante }\end{array}$ \\
\hline Hidrocarbonetos & $\begin{array}{l}\text { Carvão } \\
\text { ativado sem } \\
\text { regeneração }\end{array}$ & $\begin{array}{l}\text { Técnica de leito simples } \\
\text { Técnica de leito duplo }\end{array}$ & $\begin{array}{l}\text { Equipamentos } \\
\text { externos de } \\
\text { regeneração } \\
\text { disponíveis }\end{array}$ \\
\hline $\mathrm{CFC}$ & $\begin{array}{l}\text { Carvão } \\
\text { ativado com } \\
\text { regeneração }\end{array}$ & $\begin{array}{c}\text { Regeneração a vapor Regeneração a } \\
\text { calor }\end{array}$ & $\begin{array}{l}\text { Hidrocarbonetos + } \\
\text { CFC se líquido } \\
\text { condensável ou em } \\
\text { mistura com água, } \\
\text { ou em gás de } \\
\text { exaustão } \\
\end{array}$ \\
\hline \multirow{5}{*}{$\begin{array}{l}\text { Dióxido de } \\
\text { carbono }\end{array}$} & $\begin{array}{l}\text { Adsorção em } \\
\text { peneira } \\
\text { molecular }\end{array}$ & $\begin{array}{l}\text { Adsorção com modulação de pressão } \\
\text { com peneira molecular de carbono e } \\
\text { adsorção com modulação de pressão } \\
\text { com peneira molecular zeolítica }\end{array}$ & \multirow{3}{*}{$\begin{array}{l}\text { Disposição final } \\
\text { da solução de } \\
\text { tratamento }\end{array}$} \\
\hline & $\begin{array}{l}\text { Lavagens } \\
\text { físico- } \\
\text { químicas }\end{array}$ & $\begin{array}{c}\text { Tratamento com aminas } \\
\text { (p. ex. monoetalonamina (MEA)) }\end{array}$ & \\
\hline & $\begin{array}{l}\text { Lavagens } \\
\text { físicas }\end{array}$ & $\begin{array}{l}\text { Lavagem com água sob pressão, } \\
\text { lavagem com solventes físicos }\end{array}$ & \\
\hline & $\begin{array}{l}\text { Processo de } \\
\text { separação por } \\
\text { membranas }\end{array}$ & Compressão módulo de membranas & $\begin{array}{l}\text { Substâncias traço } \\
\text { (permeado) } \\
\text { permanecem na } \\
\text { matéria retida }\end{array}$ \\
\hline & $\begin{array}{l}\text { Métodos } \\
\text { criogênicos }\end{array}$ & $\begin{array}{c}\text { Retificação } \\
\text { Separação por congelamento }\end{array}$ & $\begin{array}{l}\text { Disposição final } \\
\text { de gelo seco }\end{array}$ \\
\hline Siloxanos & $\begin{array}{l}\text { Condensação } \\
\text { ponto de } \\
\text { orvalho } \\
\text { Condensação } \\
\text { congelamento } \\
\text { Lavagem } \\
\text { Adsorção por } \\
\text { carvão ativado }\end{array}$ & $\begin{array}{l}\text { Condensação pelo arrefecimento do } \\
\text { biogás a aprox. } 3{ }^{\circ} \mathrm{C} \text { a } 5{ }^{\circ} \mathrm{C} \\
\text { Condensação pelo arrefecimento do } \\
\text { biogás a aprox. }-25{ }^{\circ} \mathrm{C} \\
\text { Lavagem com óleo mineral } \\
\text { diferentes faixas de temperatura }\end{array}$ & $\begin{array}{l}\text { Equipamentos } \\
\text { externos de } \\
\text { regeneração } \\
\text { disponíveis; } \\
\text { deposição em } \\
\text { aterro }\end{array}$ \\
\hline
\end{tabular}

Fonte: DWA, 2010. 
3.3 Exemplos de plantas de geração de energia elétrica a partir de biogás de ETEs no Brasil.

\subsubsection{Projeto ENERG-BIOG}

A experiência do Brasil na geração de energia elétrica a partir do aproveitamento energético do biogás de esgoto vem crescendo gradualmente.

A ETE Barueri, em 2002 recebeu o projeto ENERG-BIOG- Instalação e Testes de uma Unidade de Demonstração de Geração de Energia Elétrica a partir de Biogás de Tratamento de Esgoto, desenvolvido por meio da parceria entre o Centro Nacional de Referência em Biomassa - CENBIO e a Companhia de Saneamento do Estado de São Paulo SABESP e financiado pela Financiadora de Estudo e Projetos (FINEP)/ CT - ENERG. Na oportunidade um estudo comparativo de desempenho entre as tecnologias microturbina e motor de combustão interna, para uma mesma faixa de potência foi realizado. Cabe ressaltar que a ETE Barueri é a maior da América Latina, representando um caso excepcional em termos de produção de biogás.

A estação opera através da utilização do processo de lodo ativado com mistura completa por ar difuso, fazendo parte o processo de digestão anaeróbia de lodos, e os equipamentos utilizados foram uma microturbina fabricada pela Capstone, com potência nominal de $30 \mathrm{~kW}$ e um grupo gerador (motor ciclo Otto adaptado) fabricado pela TRIGÁS com potência equivalente. Para a retirada da umidade e dos siloxanos presente no biogás foram utilizados filtros coalescentes e dois secadores por refrigeração, e para retirada do $\mathrm{H}_{2} \mathrm{~S}$ gasoso foi utilizado um filtro de carvão ativado, apenas para a microturbina (COSTA, 2006).

Segundo Costa (2006), neste projeto verificou-se que a microturbina apresenta ganhos ambientais relevantes com relação ao motor de combustão interna, por emitir baixas taxas de $\mathrm{NO}_{\mathrm{x}}$. No entanto as analises financeiras foram desfavoráveis com relação à microturbina, que apresentou um custo de quase oito vezes maior que os motores convencionais. Os equipamentos ficaram em operação apenas durante os estudos (Figura 7). 


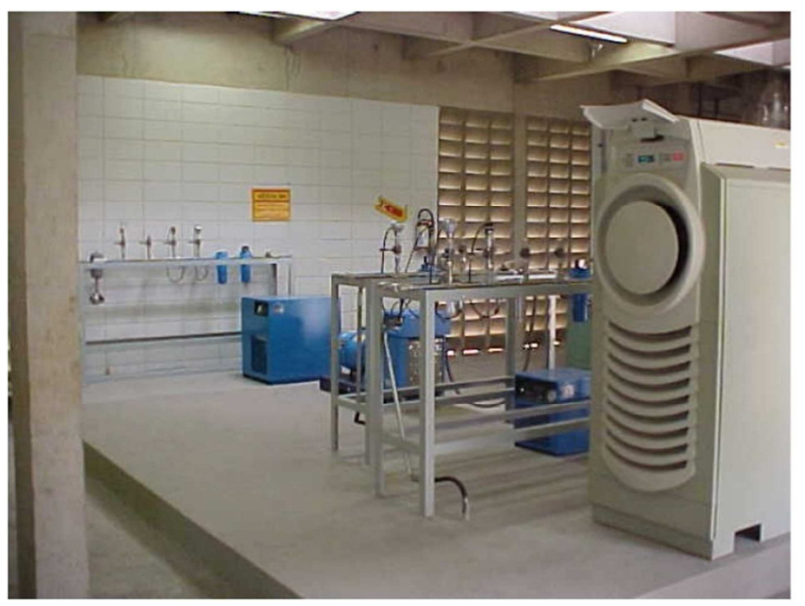

Figura 7 - Instalação do projeto ENERG-BIOG.

Fonte: CENBIO, 2004.

3.3.2 Programa de uso racional de energia e fontes alternativas (PUREFA)

Entre 2001 e 2005, pro meio do Programa de Uso Racional de Energia e Fontes Alternativas (PUREFA), um projeto da Universidade de São Paulo (USP), coordenado pela Escola Politécnica e financiado pela FINEP, o Instituto de Eletrotécnica e Energia (IEE) / Centro Nacional de Referência em Biomassa (CENBIO) desenvolveu e implantou um sistema de captação, purificação e armazenamento do biogás, produzido por um reator UASB no Centro Tecnológico de Hidráulica da USP, que trata o esgoto proveniente do Conjunto Residencial da USP (CRUSP) e ainda utilizou este biogás como combustível em um sistema de geração de energia elétrica (PECORA, 2006).

Ao contrário do projeto ENERG-BIOG, neste projeto, a planta utilizada é de pequeno porte, com capacidade de $3 \mathrm{~m}^{3} /$ hora e tratada como um projeto piloto. Para se estimar a produção diária de biogás foi utilizado os valores de DBO no esgoto, e cálculos da geração de carga orgânica por pessoa por dia e geração de biogás por pessoa por dia. O sistema de purificação foi composto por um compartimento com dois tipos de peneira molecular, uma para a retirada de umidade e a outra para retirada de $\mathrm{H}_{2} \mathrm{~S}$, e sílica gel azul, utilizada como indicador e outro compartimento com cavaco de ferro para assegurar a retirada de $\mathrm{H}_{2} \mathrm{~S}$, que possivelmente não tenha reagido com o primeiro elemento. Antes de entrar neste sistema havia ainda um recipiente para retenção de água condensada durante a passagem pela 
tubulação. Neste projeto foi utilizado um gasômetro com volume útil de $10 \mathrm{~m}^{3}$ e um motor de combustão interna de $18 \mathrm{~kW}$ da Comercial Diesel Parts (PECORA, 2006).

Segundo Pecora (2006), os resultados deste projeto mostraram que o sistema de digestão anaeróbia foi eficiente no tratamento de esgotos (Figura 8). A geração de energia elétrica foi equivalente a $0,039 \%$ da energia consumida no sistema, tornando o projeto inviável economicamente. Em uma simulação, utilizando a potência máxima do motor, a energia gerada equivaleria a $8,1 \%$ da energia consumida no sistema, o que tornaria o projeto viável (Figura 9). Concluindo que o tamanho da ETE é de fundamental importância para o aproveitamento do biogás para geração de energia.

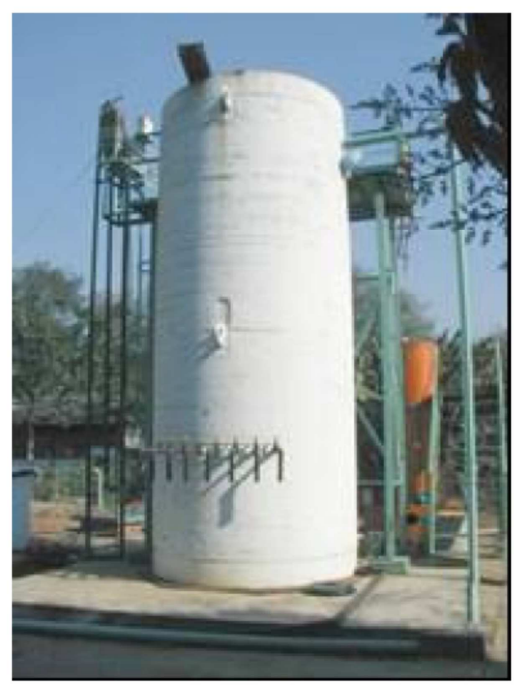

Figura 8 - Biodigestor modelo UASB existente no CTH

Fonte: CENBIO, 2003.

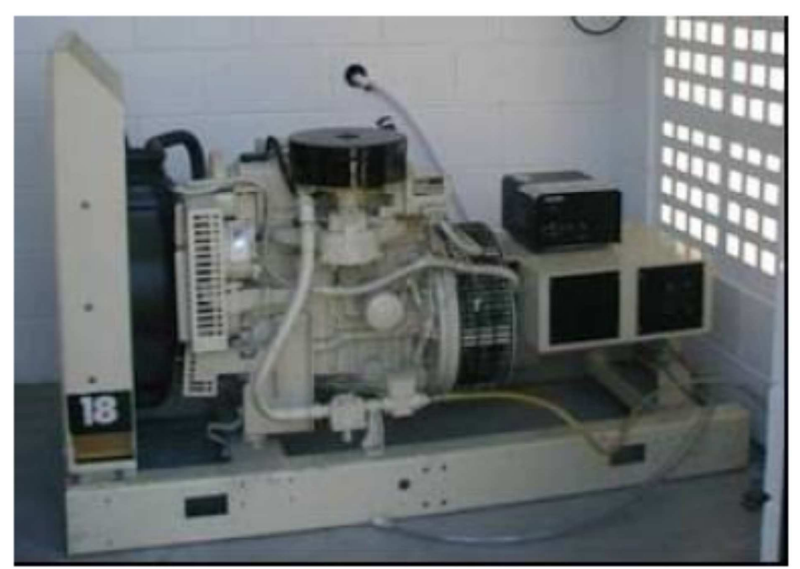

Figura 9 - Motor de combustão interna do projeto instalado no CRUSP.

Fonte: CENBIO, 2005. 


\subsubsection{ETE Ouro Verde - Sanepar}

Em 2008 a Companhia de Saneamento do Paraná (Sanepar) instalou na ETE Ouro Verde, em Foz do Iguaçu, uma Unidade Piloto de Energia Renovável que produz anualmente cerca de $50 \mathrm{mil} \mathrm{m}^{3}$ de metano por ano, utilizado para gerar energia elétrica como resultado da digestão anaeróbia do esgoto doméstico. O sistema de aproveitamento energético da ETE é constituído de coleta, filtração e armazenamento do biogás e de geração de energia elétrica por meio de um motor de combustão interna (Figura 10). A tubulação que guia o biogás possui duas derivações posicionadas antes e depois do gasômetro, as quais permitem conduzir o biogás até queimadores. Essa manobra é executada quando não se deseja armazenar o biogás no gasômetro ou quando se almeja esvaziá-lo. Esses possíveis desvios de fluxo de biogás são acionados por meio de válvulas. Entretanto, quando se deseja gerar energia elétrica, guia-se o biogás até um grupo motogerador composto por um motor Volkswagen, modelo AP 1800, com potência aparente de $25 \mathrm{kVA}$ e por um gerador KCEL, modelo 180LS, que opera com rotação de $3600 \mathrm{rpm}$, com tensão terminal em "Y" de $220 \mathrm{~V}$ e potência aparente de $50 \mathrm{kVA}$.

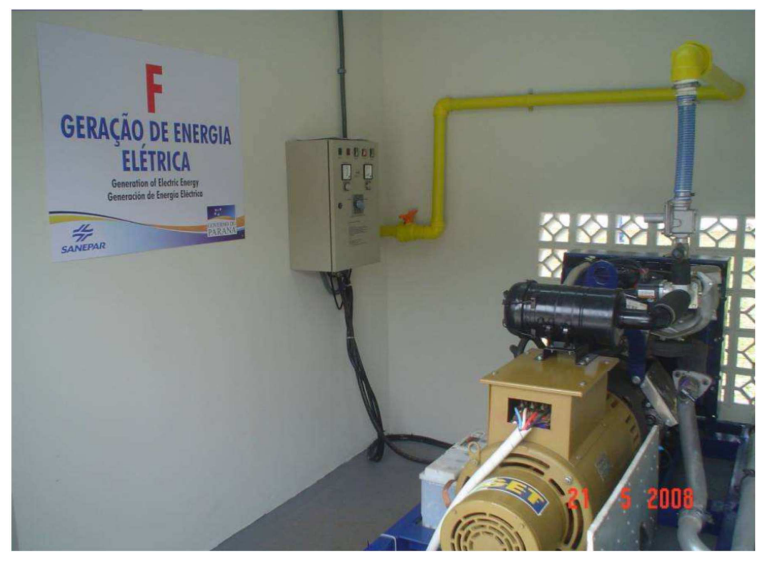

Figura 10 - Motor de combustão interna e gerador na ETE Ouro Verde em Foz do Iguaçu.

O acionamento do grupo motogerador é realizado por meio de um painel de comandos inteligente que permite o monitoramento, o controle e a proteção elétrica do sistema. Esse painel também permite a interligação em paralelo do grupo motogerador ao sistema de distribuição da Companhia de Energia do Paraná (Copel). Atualmente, o sistema de geração 
de energia elétrica da ETE Ouro Verde opera cerca de 2 horas por dia, em horário comercial, gerando nesse período aproximadamente $4 \mathrm{kWh}$ de energia elétrica.

Com uma produção de energia maior do que a demanda energética da estação (Figura 11), a Sanepar passou a disponibilizar seu excedente de energia em rede de baixa tensão da Companhia Paranaense de Energia (Copel). A autorização do uso desse excedente está na Resolução Autorizativa da Aneel $\mathrm{n}^{\circ}$ 1.482/ 2008 e Resolução Autorizativa Aneel $\mathrm{n}^{\circ}$ 1900/2009, e a interligação à rede ocorreu em dezembro de 2009. Com isso a empresa foi a primeira empresa de saneamento do Brasil a utilizar o biogás para a produção de energia elétrica.

Um projeto de instrumentação, controle e supervisão da ETE Ouro Verde está em andamento, possibilitando, por exemplo, acessar remotamente as principais grandezas elétricas inerentes à geração de energia. Esse projeto visa conhecer as características de produção, captação, guiamento, armazenamento e queima do biogás, otimizar a produção de energia elétrica e gerar parâmetros para futuros projetos de aproveitamento energético de biogás na Sanepar.

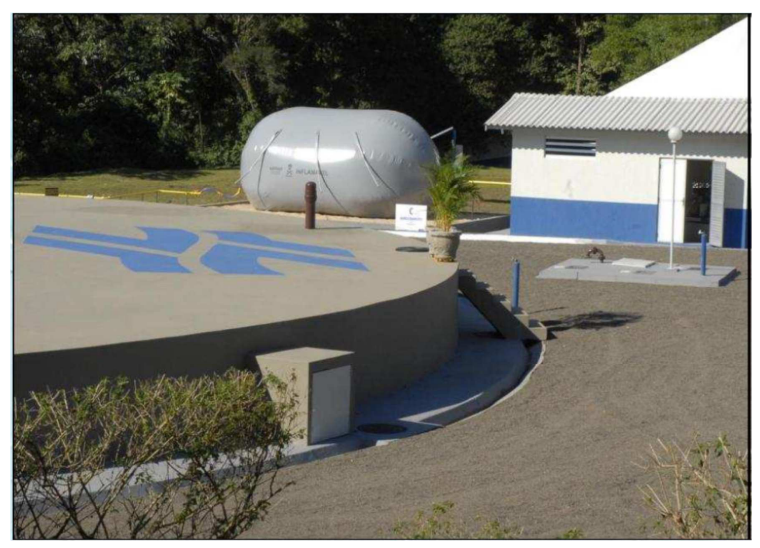

Figura 11 - ETE Ouro Verde em Foz do Iguaçu.

\subsubsection{ETE Arrudas - COPASA}

Em 2008, a Copasa - Companhia de Saneamento de Minas Gerais, iniciou seus estudos para implantação de uma unidade de aproveitamento energético na ETE Arrudas, a 
maior do Estado e que trata o esgoto da bacia Ribeirão Arrudas que contempla Contagem e Belo Horizonte, por meio do sistema de tratamento baseado em lodos ativados.

Esses estudos levaram a implantação de uma planta de cogeração termelétrica em 2011, composta basicamente por gasômetros de armazenamento de biogás, sistema de tratamento e condução do biogás tratado para três conjuntos de quatro microturbinas de 200 kW cada, totalizando uma potência instalada de 2,4 MW. O tratamento do gás ocorre em um de "Skid" para retirada de umidade e "Skid" de filtros para retirada de $\mathrm{H}_{2} \mathrm{~S}$, particulados e siloxanos. Os gases de escape passam por trocadores de calor gás-água que fornecem energia térmica para secagem de lodo dos biodigestores, em um circuito fechado, aumentando a temperatura média em seu interior, otimizando a digestão e aumentando a produção do biogás que alimenta as microturbinas (GAIO, 2013).

Segundo Gaio (2013), em 2012 a ETE Arrudas produziu em média $12.430 \mathrm{Nm}^{3} / \mathrm{dia}$ de biogás e $13 \mathrm{MWh} / \mathrm{mês}$ de energia, alcançando 53,2\% do consumo energia. No entanto estes valores vêm aumentando deste a implantação (Figura 12). A energia consumida na planta foi 37,4 MWh/mês.

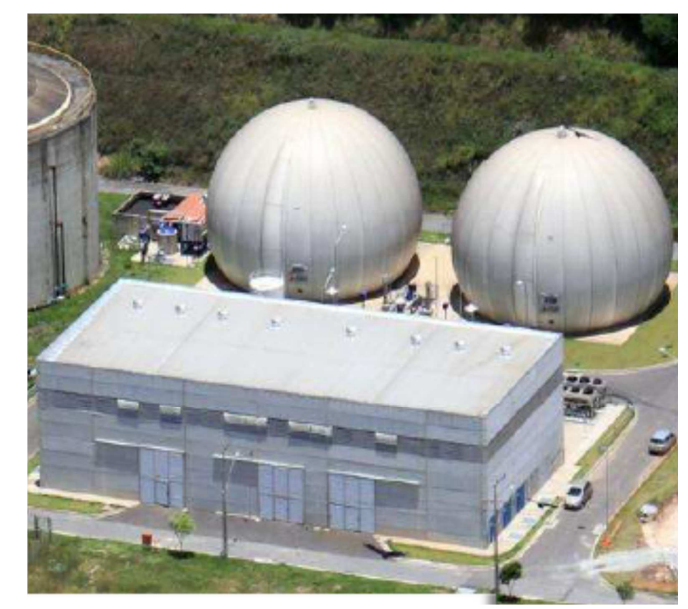

Figura 12 - ETE Arrudas: Unidade de Cogeração

Fonte: Gaio (2013).

As experiências apresentadas demostram que grandes investimentos tem sido feitos no sentido de estudar o desempenho das tecnologias disponíveis e a viabilidade de implantação destes sistemas, e que estes sistemas podem se concretizar. 


\subsection{Estímulo à novos projetos}

Segundo o PDE 2022 (EPE, 2013), nota-se uma expansão média anual de 10\% das fontes renováveis de geração (eólicas, $\mathrm{PCH}$ e termelétricas a biomassa), com destaque para as usinas eólicas. O PDE aposta que no horizonte decenal há um grande potencial de oferta de energia proveniente de fontes renováveis, no entanto, ele sempre trata do rol UHE, PCH, eólicas e térmicas a biomassa, visto que esta fontes já possuem preços mais competitivos e tecnologias que já se encontram em um grau de maturidade adequado. Apesar do PDE 2022 estar tratando da busca de novas fontes de energia, em especial as de natureza mais sustentável, ele ainda não fala em nenhum momento das fontes menos competitivas, como é o caso do biogás de resíduos e efluentes.

Mesmo considerando o aproveitamento energético como uma boa alternativa, e com a geração de energia descentralizada se mostrando viável, por proporcionar um sistema paralelo e complementar ao sistema convencional. Considerando ainda que, além da energia, o aproveitamento energético produz reconhecidos efeitos positivos, ou externalidades com impactos locais e regionais positivos, como o ambiental, social e econômico. Este sistema ainda se depara com o pouco interesse de grande parte das concessionárias e até, recentemente, à falta de legislação do setor elétrico que estimulasse este processo de produção.

Depois de muitas discussões e algumas audiências públicas, em 17 de abril de 2012 foi publicada a Resolução Normativa $n^{\circ}$ 482/2012 da ANEEL que procura remover quase todos os entraves que desestimulam a geração de energia elétrica descentralizada. Em julho de 2012, a ANEEL realizou a chamada de projeto de P\&D Estratégico n014/2012 “Arranjos Técnicos e Comerciais para inserção da Geração de Energia Elétrica a partir do Biogás oriundos de Resíduos e Efluentes Líquidos na Matriz Energética Brasileira”, no qual o principal objetivo é a proposição de arranjos técnicos e comerciais para projetos de geração de energia elétrica a partir do biogás de resíduos/efluentes líquidos, de forma integrada e sustentável. Essa chamada estratégica busca criar condições para o desenvolvimento de base tecnológica e infraestrutura técnica e tecnológica para inserção da geração utilizando biogás na matriz energética nacional.

Nesse contexto a ANEEL, por meio da Resolução Normativa $n^{\circ} 482$ da ANEEL, estabeleceu as condições gerais para o acesso de microgeração e minigeração distribuída 
sistemas de distribuição de energia elétrica e também instituiu o método de compensação de energia elétrica, na qual previu a que as fontes de energia devem ser renováveis, provenientes da energia hidráulica, solar, eólica, biomassa e cogeração qualificada.

Vários setores da economia podem se beneficiar desta medida, reduzindo custos, aumentando a eficiência energética das atividades e a sua sustentabilidade, reduzindo desigualdades regionais e mitigando impactos ambientais. Dentre eles estão o agronegócio da produção de alimentos que demanda energia para várias operações, como aquecimento de animais, eclosão de ovos, resfriamento de produtos, moagem de grãos. Devido à necessidade de pagar pela geração, transmissão e distribuição, o setor precisa de subsídios para viabilizar seu consumo de energia, enquanto produzem biomassa residual que contém energia, na forma de dejetos, efluentes e resíduos orgânicos que podem gerar biogás e esse pode ser convertido em energia elétrica.

A diferenciação entre microgeração distribuída (central geradora de energia elétrica com potência instalada menor ou igual a $100 \mathrm{~kW}$ ) e minigeração distribuída (central geradora de energia elétrica com potência instalada superior a $100 \mathrm{~kW}$ e menor ou igual a $1 \mathrm{MW}$ ) tem efeitos nos prazos de viabilização do acesso inicial da central geradora à rede da distribuidora, nos requisitos do projeto e nos instrumentos contratuais utilizados para formalizar o relacionamento comercial - seção 3.7, itens 2.5.4, 4 e 8.2 dos Procedimentos de Distribuição de Energia Elétrica no Sistema Elétrico Nacional - PRODIST -Módulo 3 (ANEEL, 2012c).

Além disso, delegou às distribuidoras adequar seus sistemas comerciais e elaborar ou revisar normas técnicas que tratem do acesso de microgeração e minigeração distribuída (art. $3^{\circ}$, caput e $1^{\circ}$, da Resolução Normativa $n^{\circ} 482$ ). Desta forma, após a formalização da solicitação de acesso pelo micro ou minigerador de energia, compete à distribuidora a realização de todos os estudos para a integração desta energia em sua rede, sem ônus ao acessante - Seção 3.7, itens 2.4.4, alínea “a”, 2.5.1 e 2.5.2 dos PRODIST - Módulo 3 (ANEEL, 2012c). Este responde, no entanto, pelos custos referentes às adequações do sistema de medição da energia produzida - Seção 3.7, item 7.2 dos PRODIST - Módulo 3 (ANEEL, 2012c) e art. $8^{\circ}$ da Resolução Normativa no 482 da ANEEL.

O sistema de compensação de energia elétrica instituído pela Agência Nacional de Energia Elétrica funciona semelhantemente ao método adotado em alguns países, denominado "net metering", ou seja, não há venda da energia produzida, e sim créditos gerados, e de acordo com Stadler, Bhandari e Madeiro (2010) esse sistema está implantado em pelo menos 10 países e em 43 estados dos Estados Unidos (EUA), onde o consumo a ser faturado, 
referente à energia elétrica ativa, é a diferença entre a energia consumida e a injetada, por posto horário, quando for o caso. $\mathrm{O}$ excedente, que não foi compensado no mês corrente, deve ser utilizado para compensar o consumo dos meses subsequentes.

Desta forma, o produtor de energia não é remunerado, mas sim integra um sistema de compensação de energia elétrica, no qual o acessante é obrigado ao pagamento do custo de disponibilidade do sistema ou da demanda contratada, mesmo que produza mais energia do que efetivamente consumiu dentro de um ciclo de faturamento. Ainda neste caso, o excedente é entregue à distribuidora, e o seu retorno financeiro (compensação) sujeito a um ciclo de faturamento futuro, no qual venha a consumir mais do que produziu, dentro de um prazo máximo de 36 meses, após este período eles expiram para o cliente e os créditos que restarem são revertidos em prol de modicidade tarifária.

A resolução ainda prevê que é possível cadastrar outros estabelecimentos que são denominados como "participantes do sistema de compensação", desde que possua o mesmo CNPJ ou CPF. Ou seja, o excedente de uma determinada unidade, em um determinado mês pode ser utilizado nos meses subsequentes em outras unidades com o mesmo CNPJ, e se houver participantes o suficiente, os créditos são completamente diluídos ao longo das compensações, aproveitando assim todo o benefício que a geração distribuída pode proporcionar ao mini ou microgerador.

Essa resolução deve ser compreendida como um importante marco regulatório no que diz respeito ao acesso efetivo de pequenos produtores às redes de distribuição. No entanto deve-se atentar à não garantia de aquisição da energia produzida a longo prazo, sendo a vigência do instrumento contratual celebrado entre as partes sujeita à Resolução Normativa $n^{\circ}$ 414/2010 da ANEEL.

Isto faz com que o retorno seja incerto, imprevisível e não garantido, ficando atrativo apenas para consumidores de médio e grande porte, que possuam, por exemplo, um gerador de energia em um estabelecimento e outros estabelecimentos que possam ser beneficiados por ele.

Parte dos elevados custos dos sistemas de geração de energia a partir do biogás se encontra no regime tarifário a que estão submetidos. Além dos equipamentos, também é tributada a operação dos sistemas, o que equivale a taxar a eletricidade gerada pelo próprio consumidor. As atividades de micro e minigeração são submetidas a impostos estaduais e federais. Os principais são o Imposto sobre Circulação Mercadorias e Serviços (ICMS), de 
âmbito estadual; e os federais, Programa de Integração Social (PIS) e a Contribuição para o Financiamento de Seguridade Social (COFINS).

O PIS, cuja alíquota é de 1,65\%, e o COFINS, cuja alíquota é de 7,6\%, são submetidos ao "regime de tributação não cumulativo em que cada etapa da cadeia produtiva se apropria dos créditos decorrentes das etapas anteriores" (Aneel 2014b). Os seus custos são calculados mensalmente e as distribuidoras utilizam métodos distintos para calculá-los. Algumas aplicam a tarifa final com impostos (PIS/COFINS e ICMS) sobre toda eletricidade consumida e, em seguida, deduzem os créditos relativos à injeção da eletricidade pelo consumidor. Outras calculam os impostos somente sobre o balanço final entre o que foi consumido via distribuidora e o que foi injetado na rede.

Como o ICMS possui alíquota que varia entre 17 e $30 \%$, o peso entre os dois modos de tributação afeta de maneira significativa o payback do investidor, desencorajando o investimento no setor.

Em alguns estados, como Minas Gerais e Tocantins, os créditos são isentos de ICMS. Mas na maioria dos outros Estados isso não acontece. Basicamente, quando você injeta a energia em excesso na rede elétrica e gera os seus créditos, o imposto de ICMS vai incidir sobre os créditos assim reduzindo um pouco a quantidade que você "acumula". Ex:

EX:1 - No estado de São Paulo (ICMS de 18\%), para cada $1 \mathrm{kWh}$ de energia que você injeta na rede você gera um crédito de $0,82 \mathrm{kWh}$.

EX:2 - No estado de Minas Gerais (o ICMS não se aplica aos "créditos de energia"), para cada $1 \mathrm{kWh}$ de energia que você injeta na rede você gera um crédito de $1 \mathrm{kWh}$.

Apesar de não ser competência da ANEEL, a tributação deveria incidir apenas na diferença, se positiva, entre os valores finais de consumo e energia excedente injetada.

Caso a diferença entre a energia consumida e gerada seja inferior ao consumo mínimo, a base de cálculo dos tributos (PIS/COFINS e ICMS) deveria ser apenas o valor do custo de disponibilidade.

Outro ponto importante a ser destacado é o fato da Resolução Normativa $n^{\circ} 482 / 2012$ não estimular o desenvolvimento de novas tecnologias, isso porque ao compensar nos mesmos termos a energia oriunda de fontes diversas, a norma incentiva o uso de fontes com menor relação custo-benefício, como a hidráulica, em detrimento de outras com custos de produção mais altos, como é o caso do biogás. Com isso, perde a oportunidade de incentivar o aperfeiçoamento das tecnologias de captação e conversão de fontes alternativas de energia. 
Seria de grande relevância o aperfeiçoamento do instrumento normativo adotado pela ANEEL, de forma a alcançar um sistema pátrio de incentive a adoção e o desenvolvimento de novas fontes de energia sustentáveis.

Voltando para o setor de saneamento, segundo o Sistema Nacional de Informações sobre Saneamento - SNIS (2007 apud MINISTÉRIO DE MINAS E ENERGIA, 2009) as despesas com energia elétrica das operadoras do setor atingem o montante de 2,58 bilhões no ano de 2007, constituindo para a maioria delas a $2^{\mathrm{a}}$ despesa da pauta de custos operacionais, sendo que em $15 \%$ delas já representam o primeiro item de custo. Além disso, se gasta 2,6\% da energia gerada no Brasil para recalcar água e esgoto (MINISTÉRIO DE MINAS E ENERGIA, 2009). Se fosse permitido e facilitado ao setor de saneamento gerar energia, para se auto-abastecer e vender os excedentes conectando-se as redes de distribuição, as despesas com energia do setor poderiam ter outra dimensão econômica. O tratamento dos esgotos e os aterros sanitários são fontes de biogás e a geração distribuída é a modalidade mais adequada para conectar em rede a energia que podem produzir. 


\section{EMISSÃO DE GASES DE EFEITO ESTUFA}

\subsection{O efeito estufa e o aquecimento global}

Segundo IPCC (2007a), o efeito estufa é um fenômeno natural causado pelo acúmulo de gases na atmosfera que provocam a retenção de calor na superfície da terra. Estes gases, conhecidos como gases de efeito estufa (GEEs) deixam a radiação proveniente do sol entrar, mas as impede de sair, funcionando como uma estufa natural e permitindo que a temperatura permaneça equilibrada, permitindo a diversificação da vida na terra.

Os gases presentes na atmosfera podem contribuir de forma direta ou indireta para o efeito estufa. Efeitos diretos ocorrem quando o próprio gás absorve radiação. Já os efeitos indiretos ocorrem quando reações químicas produzem outros gases de efeito estufa, quando determinado gás influencia o tempo de vida de outros gases ou quando afeta os processos atmosféricos que alteram o equilíbrio radioativo da terra. Gases de efeito estufa (GEE) que ocorrem naturalmente na atmosfera incluem vapor d'água, dióxido de carbono $\left(\mathrm{CO}_{2}\right)$, metano $(\mathrm{CH} 4)$, óxido nitroso $\left(\mathrm{N}_{2} \mathrm{O}\right)$ e ozônio $\left(\mathrm{O}_{3}\right)$. No entanto, alguns gases que não tem efeito direto no aquecimento global, podem afetar a absorção da radiação influenciando na formação de GEEs, como é o caso do monóxido de carbono (CO), óxidos de nitrogênio $\left(\mathrm{NO}_{\mathrm{x}}\right)$ e compostos orgânios voláteis (VOC) (USEPA, 2008b).

Nesse contexto, as causas do aquecimento global são muito pesquisadas. Existe uma parcela da comunidade científica que atribui esse fenômeno a um processo natural, afirmando que o planeta Terra está em uma fase de transição natural, um processo longo e dinâmico, saindo da era glacial para a interglacial, sendo o aumento da temperatura consequência desse fenômeno, enquanto outra parcela de cientistas acredita que as principais atribuições para o aquecimento global são relacionadas às atividades humanas, que intensificam o efeito de estufa através do aumento na queima de gases de combustíveis fósseis.

No entanto, as principais atribuições para o aquecimento global são relacionadas às atividades humanas, que intensificam o efeito de estufa por meio do aumento na queima de gases de combustíveis fósseis, como petróleo, carvão mineral e gá s natural. A queima dessas substâncias produz os mesmos gases que existem naturalmente na atmosfera e que são responsáveis pelo efeito estufa. Outros fatores que contribuem de forma significativa para as 
alterações climáticas são os desmatamentos e a constante impermeabilização do solo. Nem todos os gases contribuintes para o efeito estufa são influenciados pelo homem, este é o caso do vapor d'água. No entanto, o metano e o dióxido de carbono, maiores contribuintes para a intensificação do efeito estufa tem sua concentração na atmosfera aumentada continuamente desde a revolução industrial (COSTA, 2006).

Nesse sentido, foram elaborados diversos documentos com evidências cientificas de que, pelo menos parcialmente, este aumento seja devido às emissões de gases efeito estufa pelas atividades humanas (IPCC, 2014).

\subsection{Mudanças climáticas: um problema global}

A mudança do clima foi reconhecida como um importante problema mundial quando em 1979 foi realizada a Primeira Conferência Mundial sobre o Clima e se introduziu o conceito de que ações do homem podem potencialmente afetar o clima e serem adversas à sua qualidade de vida. Eventos similares continuaram a ser organizados para discutir evidências cientificas sobre a mudança do clima e também para definir princípios e estratégias importantes para lidar com esta nova situação (COSTA, 2006). Esses eventos culminaram na assinatura do Protocolo de Kyoto em 1997. Nele as nações desenvolvidas se comprometem a reduzir sua emissão de gases indutores de efeito estufa, em pelo menos $5 \%$ em relação aos níveis de 1990.

Estudos recentes mostram que o aumento da concentração dos gases do efeito estufa (GEE) na atmosfera, nos últimos 100 anos, causou elevação média de $0,6{ }^{\circ} \mathrm{C}$ da temperatura da Terra (IPCC, 2007a), se este padrão continuar poderão ocorrer alterações nos padrões climáticos, com impactos ambientais e sociais de grande magnitude. Uma das consequências poderá ser o aumento do nível dos oceanos devido ao derretimento das geleiras, inundação de áreas costeiras e até mesmo o desaparecimento de algumas ilhas do globo terrestre. Outra possível consequência é que com o aumento da temperatura do ar, haverá uma modificação do regime dos ventos e aumento da evaporação da água, criando mais nuvens e chuvas.

O Painel Intergovernamental de Mudanças Climáticas (Intergovernamental Panel on Climate Change - IPCC) tem estudado o assunto desde 1988. A Figura 13, que demonstra o 
aumento na temperatura média da superfície do planeta nos últimos 140 anos, foi bastante divulgada por mostrar a tendência anual de temperatura média do ar.

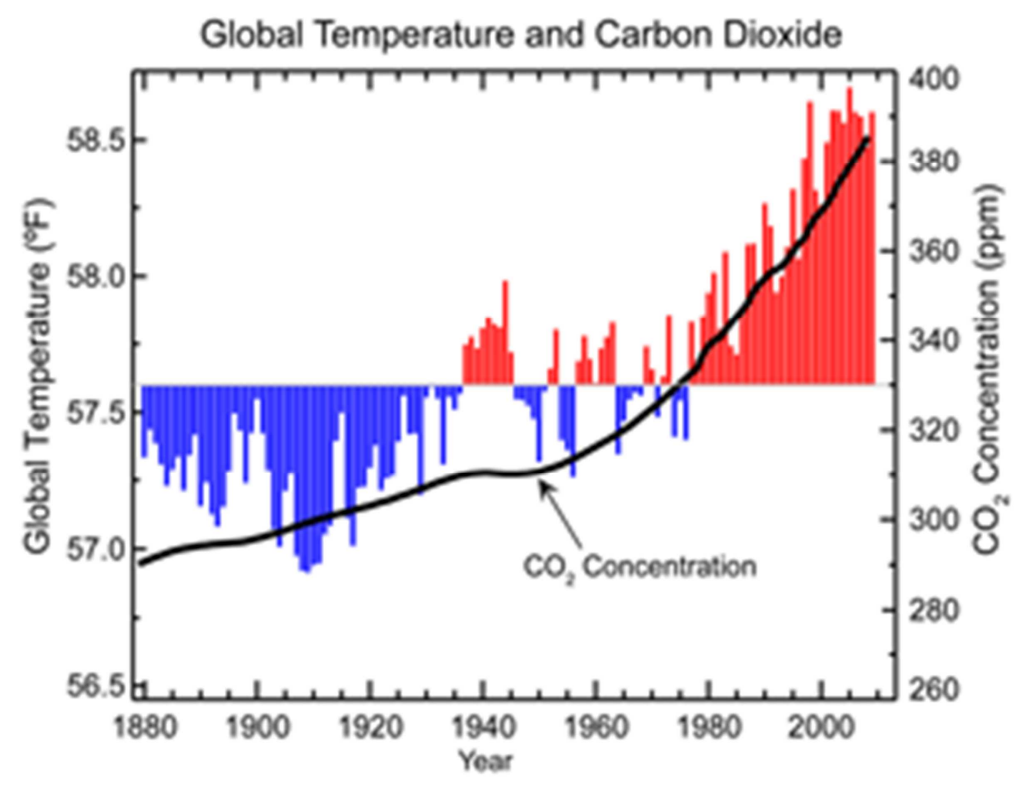

Figura 13 - Temperatura média global e concentração de $\mathrm{CO}_{2}$ na atmosfera desde 1880.

Fonte: NOAA (2013).

Segundo o $4^{\mathrm{o}}$ relatório de avaliação do IPCC (2007b), nos últimos cem anos, a temperatura média da terra aumentou $(0,74 \pm 0,18){ }^{\circ} \mathrm{C}$. Este aumento é suficiente para alterar o clima de uma região como o Círculo Polar Ártico e o Trópico de Câncer. Os resultados alertam para um aumento médio global das temperaturas entre $1,8^{\circ} \mathrm{C}$ e $4,0{ }^{\circ} \mathrm{C}$ até 2100 . Esse aumento pode ser ainda maior $\left(6,4^{\circ} \mathrm{C}\right)$ se a população e a economia continuarem crescendo rapidamente e se for mantido o consumo intenso dos combustíveis fósseis. Entretanto, a estimativa mais confiável fala em um aumento médio de $3{ }^{\circ} \mathrm{C}$. Recentemente, o Painel Intergovernamental de Mudanças Climáticas (IPCC) da Organização das Nações Unidas ratificou, por meio da publicação do $5^{\circ}$ Relatório de Avaliação sobre as Mudanças Climáticas Globais e com um nível de confiança de 95\%, que o aquecimento global é inequívoco e que tal fenômeno é causado, principalmente, pelas emissões antropogênicas de GEE (IPCC, 2013).

O IPCC também desenvolveu o conceito de potencial de aquecimento global (Global Warming Potential - GWP). Trata-se de um fator de aquecimento global desenvolvido para comparar a capacidade de cada gás enquanto GEE, em que o $\mathrm{CO}_{2}$ é a substância de referência (Tabela 6). Em termos físicos, o GWP de um gás é definido como sendo o efeito de 
aquecimento de uma emissão instantânea de $1 \mathrm{~kg}$ desse gás relativamente ao $\mathrm{CO}_{2}$. O GWP é a principal medida de comparação entre os diferentes GEE, tomando o $\mathrm{CO}_{2}$ como gás de referência. É possível determinar a quantidade de GEE em termos de $\mathrm{CO}_{2}$ eq $\left(\mathrm{CO}_{2}\right.$ equivalente) multiplicando a quantidade de cada composto pelo respectivo GWP. Na tabela são enumerados alguns GEE e seus respectivos GWP nos horizontes temporais 20, 100 e 500 anos.

Tabela 6 - GWP dos Principais gases efeito estufa.

\begin{tabular}{ccccc}
\hline GEE & Tempo de vida & GWP & GWP & GWP \\
& & 20 anos & 100 anos & 500 anos \\
\hline Dióxido de carbono $\left(\mathrm{CO}_{2}\right)$ & variado & 1 & 1 & 1 \\
Metano $\left(\mathrm{CH}_{4}\right)$ & 12 & 72 & 35 & 7,6 \\
Óxido Nitroso $\left(\mathrm{N}_{2} \mathrm{O}\right)$ & 114 & 289 & 298 & 753 \\
\hline
\end{tabular}

Fonte: Adaptado de IPCC (2007a).

$\mathrm{O} \mathrm{CO}_{2}$ é o composto de referência devido suas características por estar naturalmente presente na atmosfera e por ser o GEE emitido em maior quantidade para a atmosfera. As plantas e os oceanos constituem os principais sumidouros de $\mathrm{CO}_{2}$, o que impede que os níveis deste poluente aumentem ainda mais. No entanto, como os mecanismos de compensação nesse processo não são muito significativos quando comparados com a reserva atmosférica de $\mathrm{CO}_{2}$, uma molécula deste pode permanecer na atmosfera durante mais de um século. Por outro lado, estes mesmos mecanismos foram suficientes para manter a estabilidade na concentração de $\mathrm{CO}_{2}$ na atmosfera durante muitos séculos até à Revolução Industrial. Nas eras geológicas passadas, a quantidade de $\mathrm{CO}_{2}$ atmosférico aumentou e diminuiu em sintonia com as principais alterações climáticas, embora ainda haja a dúvida se este gás acelerou ou atrasou alguma dessas alterações (HENSON, 2009).

Segundo Lobato (2011), os gases de efeito estufa de longa vida, como dióxido de carbono, metano e óxido nitroso, são quimicamente estáveis e persistem na atmosfera, podendo exercer influência no clima a longo prazo, enquanto os gases de curta duração como o dióxido de enxofre e monóxido de carbono são quimicamente reativos e, geralmente, são eliminados por processos naturais de oxidação na atmosfera.

Atualmente, os gases de efeito estufa emitidos em maior quantidade na atmosfera são o $\mathrm{CO}_{2}$ e o $\mathrm{CH}_{4}$, que apesar de apresentarem baixo potencial de aquecimento quando 
comparado com outros gases são emitidos em maior quantidade, exercendo uma importante contribuição para as mudanças climáticas (LOBATO, 2011).

No Brasil, as emissões de $\mathrm{CO}_{2}$ (Figura 14) estão concentradas no setor mudança no uso da terra e floresta, que em 2005 representou $76 \%$ do total de emissões no país, sendo o setor de energia e processos industriais responsáveis por $22 \%$ e $2 \%$ desse valor, respectivamente. As emissões de $\mathrm{CO}_{2}$ aumentaram cerca de $42 \%$ no período de 1990 a 2005, com destaque ao setor de processo industriais que se apresentou como o menos representativo em com menor crescimento de emissões no período (Figura 15).

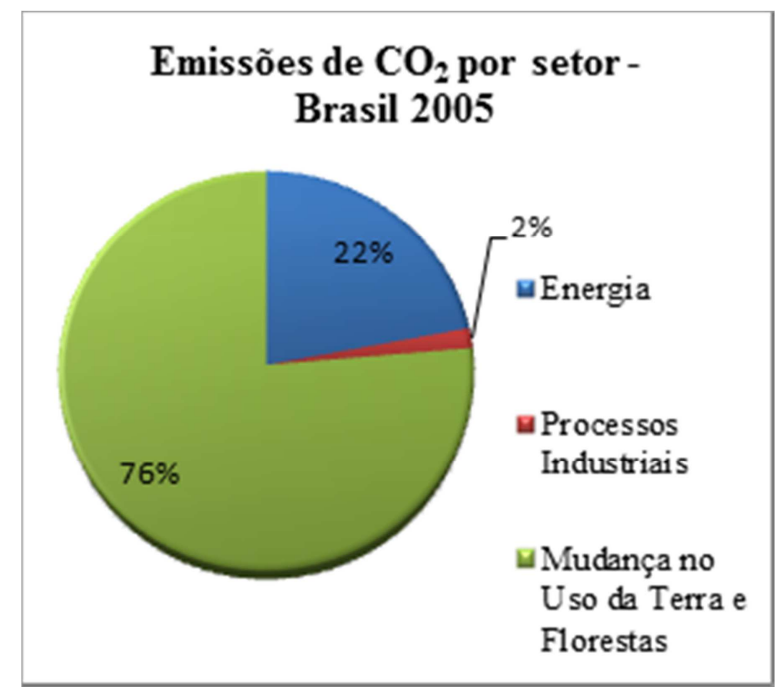

Figura 14 - Emissões de $\mathrm{CO}_{2}$ por setor no Brasil em 2005.

Fonte: Adaptado de Ministério da Ciência e Tecnologia (2010).

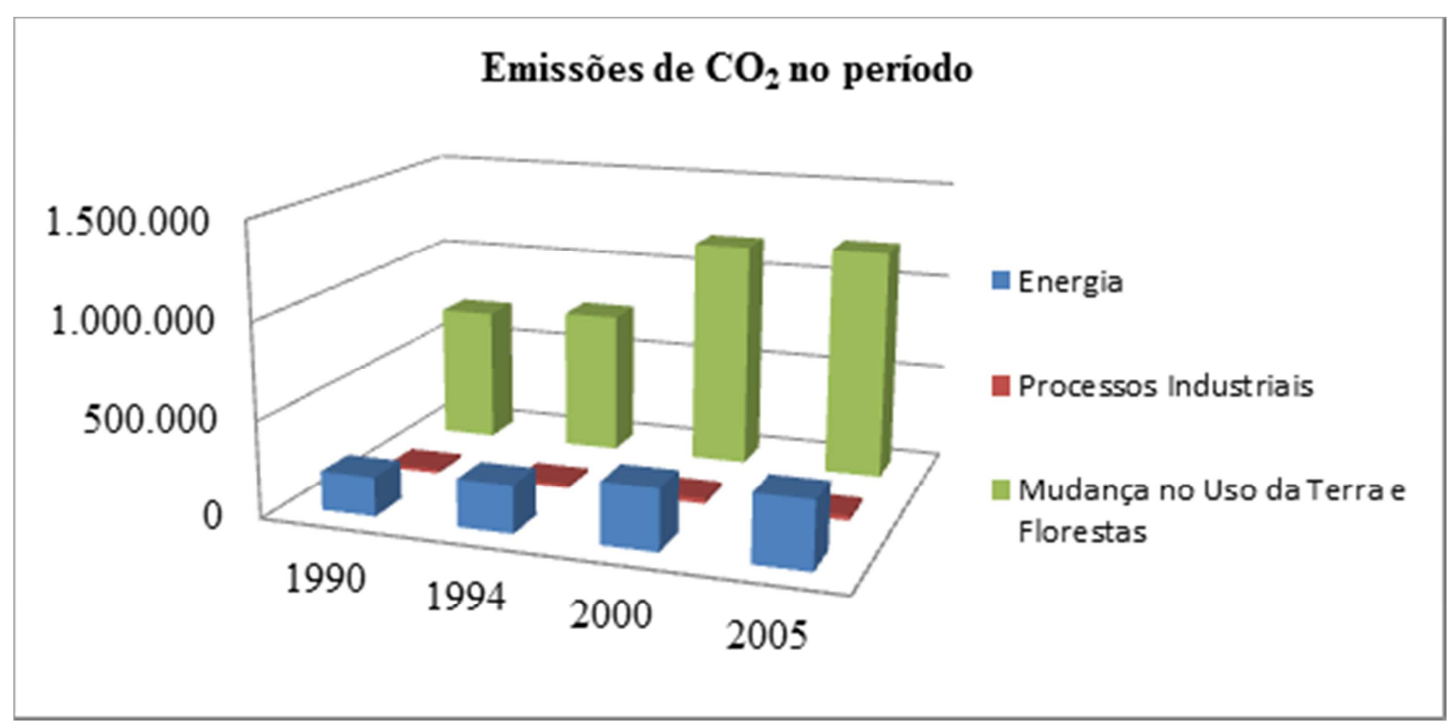

Figura 15 - Emissões de $\mathrm{CO}_{2}$ no período de 1990 a 2005 no Brasil por setor.

Fonte: Adaptado de Ministério da Ciência e Tecnologia (2010). 
É grande a preocupação mundial em atenuar também as emissões de outros GEE que não o $\mathrm{CO}_{2}$, tendo em vista que estes apresentam uma contribuição significativa para as mudanças climáticas, mas também podem ter suas emissões reduzidas por meio de ações com melhor relação benefício/custo (CHERNICHARO e STUETZ, 2008).

Neste sentido, foi lançado em 2014 um relatório intitulado "Caminhos para descarbonização profunda" (Pathways to Deep Decarbonization), no qual são apontados três pilares para se alcançar reduções de emissões consistentes com a limitação do aquecimento global em menos de $2^{\circ} \mathrm{C}$ : eficiência energética, energias de baixo carbono e troca de combustível. Além disso, ainda identifica as 15 maiores economias mundiais responsáveis por produzir $70 \%$ das emissões de gases de efeito estufa, na qual o Brasil esta incluído (IDDRI e SDSN, 2014).

Este relatório, entre outras coisas desenvolve um roteiro ilustrativo para a transição para uma economia de baixo carbono, com a intenção de se levar em conta as condições socioeconômicas nacionais, aspirações de desenvolvimento, ações de infraestrutura, dotação de recursos e outros fatores relevantes para apoias as tomadas de decisões pelos governantes para a transição econômica de baixo carbono, como a utilização de energias renováveis. $\mathrm{O}$ relatório ainda adverte que as discussões em torno das mudanças climáticas são muito conservadoras, e, que faltam cooperação entro os países, até o momento (IDDR e SDSN, 2014).

Particularmente em relação ao metano, este é um gás combustível primariamente resultante da decomposição anaeróbia de matéria orgânica em sistemas biológicos, e ações antropogênicas. Segundo El-Fadel e Massoud (2001) $70 \%$ das emissões de $\mathrm{CH}_{4}$ são provenientes de fontes antropogênicas e $30 \%$ de fontes naturais.

Dentre as fontes antropogênicas as principais emissoras são as plantações de arroz, a fermentação entérica, a queima de biomassa, o manejo de resíduos, o uso de combustíveis fósseis e as perdas de gás natural (USEPA, 2008a). Dentro de manejo de resíduos, as principais emissões são o tratamento de efluentes e a disposição de resíduos sólidos em aterros sanitários (ALVES, 1998).

O balanço entre emissões e processos de remoção de metano determina as concentrações e por quanto tempo as emissões de metano permanecerão na atmosfera. Uma molécula de metano permanece na atmosfera durante menos de uma década. No entanto, uma 
molécula dessa substância absorve entre 20 a 25 vezes mais radiação infravermelha que uma molécula de $\mathrm{CO}_{2}$.

As concentrações de $\mathrm{CH}_{4}$ na atmosfera aumentaram cerca de $150 \%$ desde 1750 , de um valor no período pré-industrial próximo a 715 ppb para 1774 ppb em 2005. Entretanto, a taxa de crescimento nas concentrações de $\mathrm{CH}_{4}$ na atmosfera diminuiu de 14 ppb.ano ${ }^{-1}$ em 1984 para menos que -5 ppb.ano ${ }^{-1}$ nos anos de 2001, 2004 e 2005 (Figura 16). O IPCC estima que mais da metade do fluxo atual de $\mathrm{CH}_{4}$ é resultado de atividades antrópicas tais com agricultura, utilização de combustíveis fósseis e decomposição de resíduos (IPCC 2007a).

A Figura 16 aponta para um recente declive nas taxas de crescimentos das concentrações de $\mathrm{CH}_{4}$ na atmosfera, implicando em um certo equilíbrio entra as fontes de emissão e os chamados sumidouros, que são os processo de remoção de metano na troposfera. O principal deles, responsável por quase $90 \%$ das remoções de $\mathrm{CH}_{4}$ se dá por meio da oxidação do metano por radicais hidroxila $(-\mathrm{OH})$ que pode levar a produção de $\mathrm{CH}_{4}$ e água. Esta é uma reação fortemente influenciada pela concentração de NOx e pode ocorrer tanto na troposfera quanto na estratosfera, esta última influenciando menos na remoção de $\mathrm{CH}_{4}$. Outros dois mecanismos importante são a remoção do metano por oxidação biológica em solos, que representam cerca de $7 \%$ das remoções e a reação do metano com átomos de cloro no ambiente marinho, responsável por cerca de 2\% das reduções (USEPA, 2008a). 


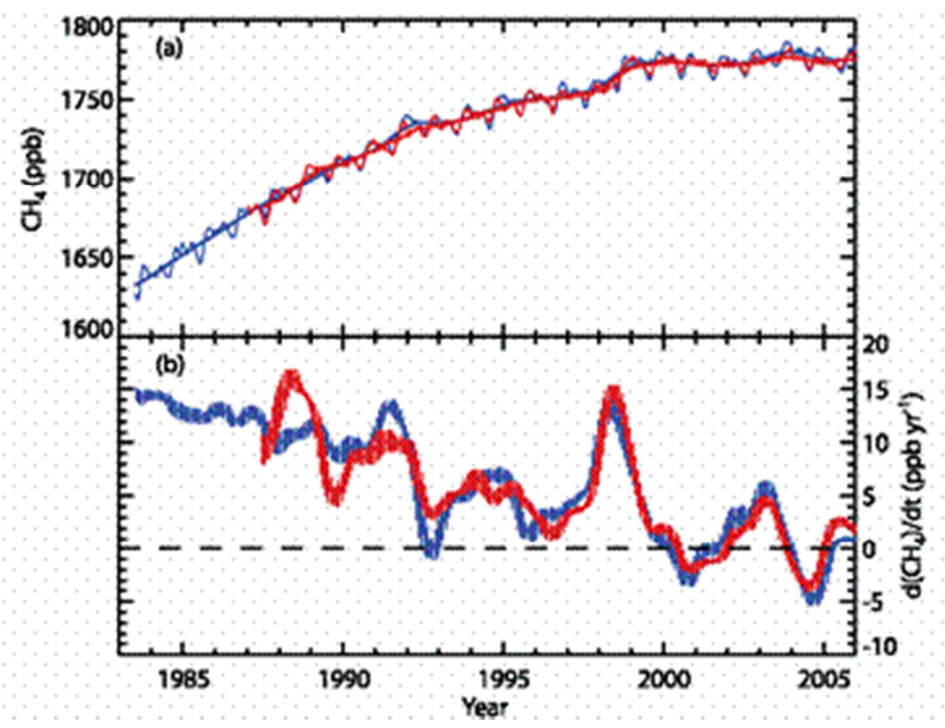

Figura 16 - Crescimento da concentração de metano na atmosfera e valores anuais de concentração para duas séries de medidas.

Fonte: IPCC (2007c).

Os níveis de emissão de metano são dependentes de variáveis como clima, características da produção industrial e agrícola, tipos e usos de energia, e as práticas de gestão de resíduos. Por exemplo, a temperatura e a umidade têm um efeito significativo sobre o processo de digestão anaeróbia, que é um dos principais processos biológicos que podem causar as emissões de metano tanto em fontes naturais como de origem antrópica, e isso faz com que estes níveis possam variar significativamente de uma região para outra. Outra variável significativa para alterações nas emissões de metano a partir de fontes específicas são: aplicação de tecnologias para coleta e reaproveitamento do $\mathrm{CH}_{4}$ proveniente da gestão de resíduos sólidos e esgoto, e mineração de carvão e gerenciamento de resíduos animais (USEPA, 2008a).

A Figura 17 apresenta as emissões relativas de metano no Brasil para o ano de 2005.

4 As linhas azuis referem-se ao monitoramento do "National Oceanic and Atmospheric Administration's Global Monitoring Division (NOAA/GMD)" e as linhas vermelhas ao monitoramento do "Advanced Global Atmospheric Gases Experiment (AGAEE)". 


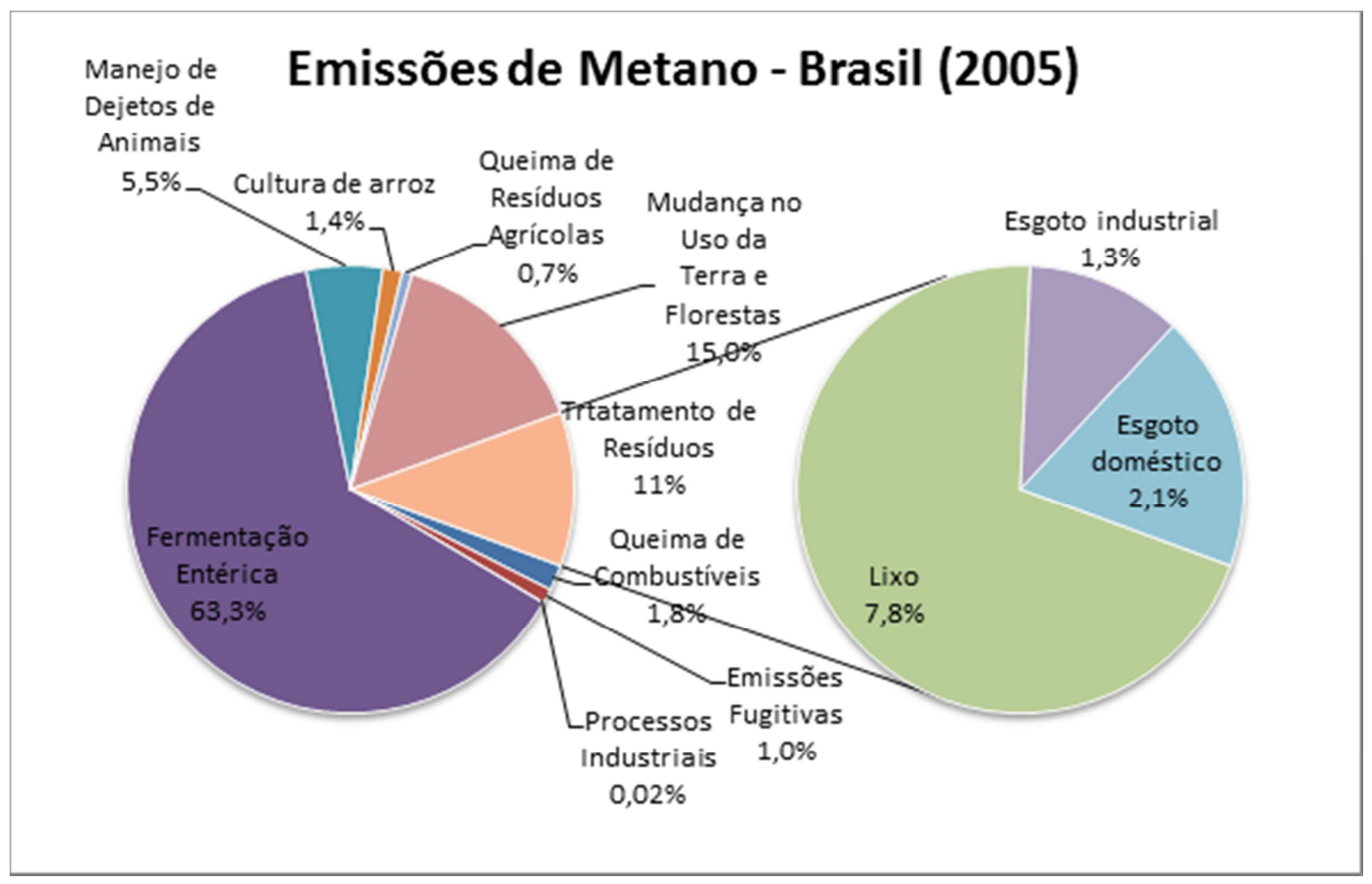

Figura 17 - Contribuição relativa de diversas fontes de emissão de $\mathrm{CH}_{4}$

Fonte: Adaptado de Ministério da Ciência e Tecnologia (2010).

Segundo estes dados, a fermentação entérica foi a maior responsável pelas emissões de $\mathrm{CH}_{4}$, com 63,3\% das emissões, o que somado ao manejo de dejetos animais, cultivo de arroz e a queima de resíduos agrícolas, confere ao setor agropecuário o título de maior emissor de metano no ano de 2005 no Brasil, com 75,6\%. Seguido pelo setor de mudança no uso da terra e florestas, no qual as emissões ocorrem pela queima da biomassa nas áreas de desflorestamento, que corresponde à $12,4 \%$ das emissões, valor muito abaixo do primeiro e com crescimento acentuado de 76\% (MCT, 2010).

As emissões do setor de tratamento de resíduos representaram $11 \%$ do total das emissões de $\mathrm{CH}_{4}$ em 2005, sendo a disposição de resíduos sólidos e o tratamento de esgoto responsáveis por $70 \%$ e $30 \%$ desse valor, respectivamente. O setor apresentou aumento de $84 \%$ de emissões no período de 1990 a 2005. (MCT, 2010).

O setor de energia abrange queima imperfeita de combustíveis que corresponde a $1,8 \%$ das emissões em 2005 e as missões fugitivas de $\mathrm{CH}_{4}$ que corresponde a apenas $1 \%$ das emissões no período. Apesar de pouco representativo as emissões fugitivas aumentaram $116 \%$ no período de 1990 a 2005. O setor teve um aumento de $28 \%$ no mesmo período. A contribuição de emissões dos processos industriais aparece inexpressiva nesse contexto (MCT, 2010). 
Segundo El-Fadel e Massoud (2001) as emissões de $\mathrm{CH}_{4}$ originadas do tratamento de esgoto doméstico e efluente industrial correspondem a cerca de $5 \%$ da emissão global de $\mathrm{CH}_{4}$.

4.3 Gestão das emissões de gases de efeito estufa

Existe uma crescente pressão da sociedade por ações relacionadas à mitigação das mudanças climáticas, havendo uma busca constante pelas empresas em reduzirem as emissões de seus processos ou serviços e de adotarem metas voluntárias de redução (BRASIL, SOUZA JÚNIOR e CARVALHO JÚNIOR, 2008). Para se chegar à quantidade de gases de efeito estufa, é necessária a elaboração de inventários, que permite conhecer o perfil e realizar um diagnóstico das emissões que possibilitará estabelecer estratégias, planos e metas para redução e gestão das emissões de gases de efeito estufa. Nesse contexto, o "The Greenhouse Gas Protocol - A Corporate Accouting and Reporting Standard" (O protocolo de gases de efeito estufa - um padrão corporativo de contabilização e reporte), ou simplesmente GHG Protocol, lançado em 1998 e revisado em 2004, é hoje a ferramenta mais utilizada mundialmente pelas empresas e governos para entender, quantificar e gerenciar suas emissões.

O GHG Protocol vêm desenvolvendo um conjunto de ferramentas de cálculos para auxiliar as empresas a inventariarem as suas emissões de GEE e apresentam outros documentos de orientação. Essa iniciativa foi desenvolvida pelo World Resources Institute (WRI) em associação com o World Business Council for Sustainable Development (WBCSD), além de outras contribuições. Entre as características da ferramenta destacam-se o fato de oferecer uma estrutura para contabilização de GEE, o caráter modular e flexível, a neutralidade em termos de políticas ou programas e a questão de ser baseada em um amplo processo de consulta pública e ser compatível com as normas da International Organization for Standardization (ISO) e com as metodologias de quantificação do IPCC.

Sua aplicação no Brasil se deu com o Programa Brasileiro GHG Protocol, em 2007, que adaptou o modelo para o contexto nacional. Além disso, as informações geradas podem ser aplicadas aos relatórios e questionários de iniciativas como "Carbon Disclosure Project", Índice Bovespa de Sustentabilidade Empresarial (ISE) e "Global Reporting Initiative" (GRI) 
(PROGRAMA BRASILEIRO GHG PROTOCOL, 2010). A utilização de orientações consolidadas é de extrema importância, pois sustenta a uniformidade dos inventários.

O Programa Brasileiro GHG Protocol tem como objetivo promover, por meio de engajamento e capacitação técnica e institucional, uma cultura corporativa de caráter voluntário para a identificação, o cálculo e a elaboração de inventários de emissões de GEE. Por meio do desenvolvimento e disseminação das especificações do Programa Brasileiro GHG Protocol, baseadas nas melhores técnicas internacionais, tais como GHG Protocol, normas ISO e IPCC; identificando e, quando necessário, adaptar ou desenvolver metodologias e fatores de emissão para o cálculo de emissões antrópicas por fontes de GEE e remoções antrópicas por sumidouros de GEE no Brasil. Com a finalidade de criar um registro público de fácil acesso para empresas e organizações públicas e privadas informarem suas emissões de GEE, de acordo com as Especificações do Programa (PROGRAMA BRASILEIRO GHG PROTOCOL, 2010).

Qualquer entidade legalmente constituída pode participar do programa, e devem incluir no inventário todos os gases internacionalmente reconhecidos como gases de efeito estufa regulados pelo Protocolo de Kyoto, a saber: $\mathrm{CO}_{2}, \mathrm{CH}_{4}$, Óxido Nitroso $\left(\mathrm{N}_{2} \mathrm{O}\right)$, Hexafluoreto de enxofre ( $\left.\mathrm{SF}_{6}\right)$, hidrofluorcarbonos (HFCs) e Perflurcarbonos (PFCs), que deverão ser calculados pelo Potencial de Aquecimento Global (GWP) que resulta em dióxido de carbono equivalente para cada gás (PROGRAMA BRASILEIRO GHG PROTOCOL, 2010).

A contabilização, unificação, elaboração e publicação de inventário de GEE no âmbito do Programa Brasileiro deve estar em conformidade com os princípios de contabilização apresentados no "GHG Protocol Corporate Standard" e na norma 14064-1, de forma a segurar que o inventário de GEE represente, de maneira justa e transparente, todas as emissões de GEE da organização (PROGRAMA BRASILEIRO GHG PROTOCOL, 2010).

A empresa que aderir ao programa deve determinar os seus limites organizacionais e estabelecer os seus limites operacionais, o que envolve a identificação das emissões diretas ou indiretas por meio de escopos. As emissões diretas de GEE são emissões provenientes de fontes que pertencem ou são controlados pela organização, já as indiretas são aquelas resultantes das atividades da organização que está inventariando suas emissões, mas que ocorrem em fontes que pertencem ou são controladas por outra organização (PROGRAMA BRASILEIRO GHG PROTOCOL, 2010). 
O Escopo 1 abrange as emissões diretas de $\mathrm{CO}_{2}$ geradas na combustão estacionária para geração de eletricidade, vapor, calor ou energia com o uso de equipamentos em um local fixo; combustão móvel para transportes em geral, emissões de processos físicos e químicos (processo); emissões fugitivas e emissões agrícolas (PROGRAMA BRASILEIRO GHG PROTOCOL, 2010).

O Escopo 2, por sua vez, contabiliza as emissões indiretas de GEE provenientes da aquisição de energia elétrica e térmica que é consumida na corporação. Já o Escopo 3 contabiliza outras emissões indiretas de GEE, o seu relato é opcional, pois trata das emissões que ocorrem em fontes que não pertencem ou não são controladas pela empresa (PROGRAMA BRASILEIRO GHG PROTOCOL, 2010).

As emissões resultantes da combustão de biomassa devem ser tratadas de forma diferente daquelas provenientes de combustível fósseis. $\mathrm{O} \mathrm{CO}_{2}$ liberado na combustão de biomassa é igual ao $\mathrm{CO}_{2}$ retirado da atmosfera durante o processo de fotossíntese e, portanto, considerado "carbono neutro". No entanto, a queima desses combustíveis também libera $\mathrm{N}_{2} \mathrm{O}$ e $\mathrm{CH}_{4}$ que não fazem parte da fotossíntese e, por isso, devem ser reportados junto a contabilização dos combustíveis de origem fóssil (PROGRAMA BRASILEIRO GHG PROTOCOL, 2010).

Ainda segundo o Programa Brasileiro GHG Protocol (2010), quando mudanças estruturais significativas atingem as empresas, como aquisições, separações e fusões, para facilitar comparações ao longo do tempo, os dados históricos devem ser recalculado. A escolha do ano base deve ser feita conforme a situação mais relevante no tempo da empresa, para o qual se tem dados fidedignos. As empresas podem necessitar fazer o monitoramento das emissões ao longo do tempo, devido à variedade dos objetivos de negócios, como o estabelecimento de metas de redução de GEE, participação em relatórios públicos, gestão dos riscos e oportunidades ou para ir ao encontro das necessidades dos investidores e de outros grupos de interesse.

As empresas devem selecionar e relatar um ano base, levando em consideração a disponibilidade de dados de emissões que possam ser comprovados e especificar quais as razões que levaram à escolha de tal ano. Pode ser escolhida uma média anual de emissões, sobre vários anos consecutivos (PROGRAMA BRASILEIRO GHG PROTOCOL, 2010).

Após estabelecer os limites do inventário é necessário identificar fontes de emissão, escolher a abordagem de cálculo, coletar dados e fatores de emissão, aplicar ferramentas de 
cálculo e compilar dados em nível corporativo (PROGRAMA BRASILEIRO GHG PROTOCOL, 2010).

Com relação às ferramentas de cálculo o Programa Brasileiro GHG Protocol desenvolveu metodologias de cálculo e de fatores de emissão documentados para fontes comuns a vários setores. Esses fatores de emissão documentados relacionam as emissões de GEE com medidas de atividade em uma fonte de emissão. As diretrizes do IPCC são relativas a metodologias e as técnicas de cálculo, que vão desde a aplicação de fatores de emissão até a medição direta, que apesar de incomuns, podem ser feitas por meio de balanços de massa ou cálculos estequiométricos (PROGRAMA BRASILEIRO GHG PROTOCOL, 2010).

Os inventários de empresas membros do Programa Brasileiro são publicados por meio do Registro Público de Emissões de GEE. Um inventário completo de GEE deve fornecer integralmente a contabilização de todas as emissões de GEE integrantes dos Escopos 1 e 2, resultante de fontes localizadas dentro dos limites geográficos estabelecidos pelo Programa e dentro dos limites organizacionais e operacionais estabelecidos pelo participante. As informações publicadas devem respeitar os princípios básicos do Programa. Essas informações poderão ser verificadas por uma terceira parte independente (auditoria), e serão reconhecidos de modo diferente dos inventários não verificados. A verificação é uma avaliação objetiva que permite a análise da conformidade, de acordo com os princípios da verificação das informações é de assegurar que os dados relatados representem um relatório fiel e transparente das emissões de GEE da empresa. A verificação das emissões fará com que haja credibilidade de informações das emissões, aumentando a confiança dos grupos de interesse, confiança na gestão, melhorias nas práticas dos registro, além de preparar a empresa para futuras exigências em programas obrigatórios de GEE (PROGRAMA BRASILEIRO GHG PROTOCOL, 2010).

Durante a contabilização, um ponto constantemente questionado é sobre as incertezas inerentes à contabilização das emissões de GEE, o que de acordo com o IPCC (1996) são inevitáveis na realização de um inventário nacional, devido às diferentes interpretações nas definições e suposições, além do uso de representações simplificadas, como médias, sobretudo de fatores de emissão, e hipóteses para representar as características de uma determinada população. Ainda segundo o IPCC (1996) há as incertezas nos dados de atividades, e a própria incerteza científica dos processos de transferência de emissões e remoções de gases de efeito estufa, que resultam no acúmulo de incertezas de um inventário. 
Adicionalmente, o Programa Brasileiro GHG Protocol (2010) informa que apesar dos esforços mais completos, as estimativas para inventários de GEE podem ser consideradas altamente incertas, devido ao seu caráter subjetivo que não podem ser usadas como uma medida de qualidade imparcial para comparar todas as categorias de origem ou diferentes empresas. São poucas as exceções, como, por exemplo, quando duas instalações funcionalmente similares utilizam metodologias de cálculo idênticas.

Segundo Programa Brasileiro GHG Protocol (2010), diante da busca pela redução das incertezas surge uma oportunidade das empesas empreenderem esforços para compreender as inseguranças e determinar a qualidade do inventário, além de estabelecer linhas de comunicação com os fornecedores de dados, dando oportunidades para melhoria na qualidade dos dados fornecidos e nos métodos utilizados, além de fornecer informações valiosas para os revisores, verificadores e gestores, que futuramente poderão definir prioridades de investimentos para melhorar as fontes de dados e metodologias utilizadas no inventário.

Em geral as incertezas são medidas por intervalos, ou seja, uma faixa de incerteza, expresso em $\pm \%$ do valor médio relatado, por exemplo, $100 \pm 5 \mathrm{tCO}_{2 \text { eq }}$ e deverá compreender suas informações de incertezas de parâmetros utilizando uma abordagem totalmente quantitativa. O Programa Brasileiro GHG Protocol (2010) disponibiliza: duas opções de técnicas matemáticas: o método da propagação de erros de primeira ordem, também conhecido como método gaussiano; ou método baseado em uma simulação de Monte Carlo.

\subsection{Mercado de certificado de emissões evitadas de carbono}

Foram elaboradas, nas reuniões do protocolo de Kyoto, metas de redução das emissões de carbono para cada país envolvido, para auxiliar os países a atingir a meta caso a redução não fosse atingida em sua totalidade. Neste sentido, foram criados os certificados de emissão evitadas de carbono como forma de auxiliar a compensação e despertar nos países a vontade política de rever seus processo industriais (KHALILI, 2003).

Esses certificados são créditos de carbono que autorizam o direito de poluir. Agências de proteção ambiental emitem esses certificados autorizando as empresas a emitir o gás carbono e outros gases poluentes. Inicialmente são identificadas as empresas que mais poluem no país e são estabelecidas, por lei, metas de redução de emissão. As empresas que não 
atingem suas metas têm que comprar esses certificados das empresas mais bem sucedidas na redução de sua emissão de carbono. (KHALILI, 2003)

Créditos de carbono ou certificado de emissões evitadas são certificados emitidos quando ocorre a redução de emissão de gases do efeito estufa (GEE). Por convenção, uma tonelada de dióxido de carbono $\left(\mathrm{CO}_{2}\right)$ equivalente corresponde a um crédito de carbono. Este crédito pode ser negociado no mercado internacional. A redução da emissão de outros gases que também contribuem para o efeito estufa também pode ser convertida em créditos de carbono, utilizando o conceito de carbono equivalente. Dessa forma, o que se comercializa são as reduções de emissão e não os gases, do contrário não haveria coerência com a Convenção sobre Mudanças Climáticas.

Um sistema de comércio de emissões é um tipo de mercado de carbono, um instrumento econômico aplicado por uma autoridade ou adotado voluntariamente, para incentivar a redução de emissões por meio de sua precificação. Ele não é o único instrumento de política pública para reduzir emissões na economia nem é o único instrumento econômico possível para esse tipo de tarefa.

O poder público tem diferentes ferramentas possíveis para reduzir as emissões de sua economia, e dentre as ferramentas econômicas possíveis (tributação, financiamento, subsídios, tarifas preferenciais, etc.), o sistema de comércio de emissões tem sido um dos instrumentos de maior destaque. Para tais sistemas é estabelecido um teto (cap) como limite máximo de emissões para o conjunto de participantes do sistema, determinando um volume correspondente de permissões a serem emitidas no período. As permissões são distribuídas ou vendidas às fontes emissoras cobertas por essa regulação. Cada participante pode comercializar suas permissões de acordo com sua projeção de emissões para o ano vigente.

Desse modo, um participante cujo volume de GEE emitido, em toneladas de $\mathrm{CO}_{2}$ equivalente, seja inferior ao volume de permissões que possui (recebidas diretamente da autoridade responsável pelo sistema ou adquiridas no mercado) pode vender o excesso de permissões a outros participantes cujas emissões excederem o volume de permissões que possuem.

Apesar das difíceis negociações internacionais a respeito do clima, várias economias estão em estágios de planejamento, implementação ou aperfeiçoamento de suas ações de mitigação das mudanças climáticas.

Um dos exemplos mais notáveis de mercado de carbono cap-and-trade atualmente em funcionamento é o Sistema de Comércio de Emissões da União Europeia (EU ETS, sigla em 
inglês), em funcionamento desde 2004. Iniciativa pioneira no esforço para redução de emissões do bloco europeu, o EU ETS tornou-se referência para o desenvolvimento de sistemas similares ao redor do mundo nos anos seguintes, em especial o do estado norteamericano da Califórnia e alguns sistemas regionais dentro da China.

O mercado de carbono também existe fora do contexto do Protocolo, com vários programas voluntários de redução das emissões, como os dos EUA.

A Bolsa do Clima de Chicago (CCX), por exemplo, vem batendo recordes de preços e de volumes. Só em 2007, foram negociados 23 milhões de toneladas. Só nos primeiros cinco meses de 2008 foram 37 milhões. E o preço da tonelada subiu de uma média de US\$ 3,50 para US\$ 7,40. O mercado voluntário abre as portas para a inovação, já que não tem muitas regras preestabelecidas como no Protocolo de Quioto, e para projetos de menor escala que seriam inviáveis sob Quioto.

Outras bolsas voluntárias são: ECX - Bolsa do Clima Européia; NordPoll - (Oslo); EXAA - Bolsa de Energia da Áustria; BM\&F (Brasil) - Por enquanto somente trabalha com o leilão de créditos de carbono; New Values/Climex (Alemanha); Vertis Environmental Finance (Budapeste); Bluenext, antiga Powernext (Paris) e MCX - Multi-Commodity Exchange (Índia).

Essas ações, a nível nacional, têm o potencial para superar coletivamente a lacuna regulamentar internacional. Hoje, cerca de 40 países e mais de 20 jurisdições subnacionais estão colocando um preço para o carbono. Juntos, estes instrumentos de precificação do carbono cobrem quase 6 gigatoneladas de $\mathrm{CO}_{2}$ equivalente $\left(\mathrm{GtCO}_{2} \mathrm{eq}\right)$ ou cerca de $12 \%$ das emissões de GEE anuais globais (WORLD BANK, 2014).

Com relação aos preços, além das flutuações temporais, há uma variação significativa entre os mercados. Partindo de US\$ $1 / \mathrm{tCO}_{2}$, realizado através de taxação no México, até US\$ $168 / \mathrm{tCO}_{2}$ no realizado através das taxações na Suécia. Os preços em esquemas de comércio de emissões tendem a ser menores, com maior agrupamento sob US\$ 12 / $\mathrm{tCO}_{2}$. A principal razão para os preços mais baixos atualmente visto em esquemas de comércio de emissões parecem estar relacionados aos impostos aplicados à indústria e a carga fiscal sobre os agregados familiares, evitando assim problemas de competitividade e de fuga de carbono. O aumento da ambição nestes esquemas de comércio de emissões poderia levar ao aumento dos preços (WORLD BANK, 2014).

Ressalta que a cooperação continua sendo um elemento-chave para o sucesso de um mercado internacional, e que a crescente tendência de ações nacionais foi reforçada à partir da 
colaboração entre as partes interessadas como, por exemplo, a cooperação entre os mercados da Califórnia e Québec (WORLD BANK, 2014).

Em relação ao Brasil, o relatório assinala que o governo brasileiro está olhando para vários instrumentos de precificação do carbono, incluindo impostos. Porém, sem progresso notável no estabelecimento de planos nacionais em mercados de carbono (WORLD BANK, 2014).

A nível regional, foram encontradas oposições da indústria para o lançamento de um mercado no Rio de Janeiro e nenhum progresso foi feito sobre os planos de mercado para São Paulo. No entanto, algumas empresas já demonstraram interesse em ganhar experiência prática em um mercado de comercialização de emissões de carbono. Esse fato levou ao lançamento de uma plataforma de comércio de emissões pela Bolsa Verde do Rio de Janeiro, e a criação da iniciativa Empresas Pelo Clima (EPC).

A EPC é um mercado de comércio de emissões simulado com 22 grandes empresas, 194 emissores de um total de $22 \mathrm{MtCO}_{2} \mathrm{e}$ em 2012, até o final de 2014, 195 Subsídios puderam ser negociados através da plataforma de mercados de carbono da BVTrade. No último trimestre da simulação, permissão de emissão atingiu um dos seus picos de preço, equivalente a $\mathrm{R} \$ 33,00$. 


\section{MÉTODOS DE ESTIMATIVA DE PRODUÇÃO DE BIOGÁS}

Os métodos atualmente utilizados para estimar as emissões de metano derivado do esgoto doméstico são baseados na Demanda Química de Oxigênio (DQO) e Demanda Bioquímica de Oxigênio (DBO). O método publicado pelo IPCC, o mais utilizado, segundo El-Fadel e Massoud (2001), disponibiliza diretrizes para estimar as emissões de metano associadas com o tratamento de esgotos domésticos (IPCC, 2006), as quais normalmente são empregadas na estruturação de inventários de emissões de gases do efeito estufa. Outro método bastante conhecido e utilizado é o proposto pela UNFCCC (2013) e é tipicamente empregado em estudos sobre mecanismos de desenvolvimento limpo.

No Brasil, as taxas de recuperação de metano em reatores UASB, estudas e reportadas por Chernicharo (1997), podem ser obtidas a partir do balanço de massa da DQO, incluindo a produção de sólidos no sistema e a conversão dos sólidos voláteis totais em DQO.

Seguindo esse trabalho, Souza (2010) avaliou os processos de formação, movimentação, desprendimento e consumo de metano e gás sulfídrico, resultantes do tratamento de esgoto doméstico em reatores UASB. Lobato, Chernicharo e Souza (2012), desenvolveu um modelo matemático que poderia estimar mais precisamente a fração de DQO recuperada como metano no biogás e que, por meio da inclusão de todas as vias de conversão e perdas no reator, incluindo a porção de DQO utilizada para a redução de sulfatos e as porções perdidas como metano dissolvido no efluente ou emitidos para a atmosfera.

A Companhia de Tecnologia de Saneamento Ambiental - CETESB, desenvolveu em 2006, em parceria com o Ministério da Ciência e Tecnologia, a Secretaria de Estado do Meio Ambiente de São Paulo e a Companhia de Tecnologia de Saneamento Ambiental - CETESB, um programa de computador que estima a emissão de metano de uma instalação de tratamento anaeróbio de esgotos domésticos, de tratamento anaeróbio de efluentes industriais ou de tratamento anaeróbio de resíduo rural, com o objetivo de auxiliar a avaliação de viabilidade do uso energético do biogás gerado pela degradação de efluentes em estações de tratamento anaeróbio, visando contribuir para aumentar o interesse em torno deste tema.

É importante considerar que as emissões de $\mathrm{CH}_{4}$ a partir do tratamento de águas residuárias variam de país para país, dependendo da tecnologia de tratamento e das práticas de gestão adotadas, bem como das características das águas residuárias e dos métodos de estimativa (LOBATO, 2011). 
5.1 Método de estimativa IPCC (2006)

Segundo o IPCC (2006), para estimar as emissões de $\mathrm{CH}_{4}$ derivadas do esgoto doméstico são sugeridas três etapas:

$1^{\circ}$ - Estimar o conteúdo total de matéria orgânica no esgoto (total organic waste TOW).

Que pode ser calculado pela Equação (1):

$T O W=P \times Q P C_{D Q O} \times 0,001 \times I \times 365$

Em que,

TOW = total de matéria orgânica $\left(\mathrm{kgDBO} \cdot \mathrm{ano}^{-1}\right)$;

$P=$ população (hab);

$Q P C D Q O=$ contribuição per capta de DQO $\left(\mathrm{g} \cdot \mathrm{hab}^{-1} \cdot \mathrm{dia}^{-1}\right)$;

$I=$ fator de correção para contribuição industrial nas redes coletoras $(1,25$ quando há contribuição industrial e 1 quando não há contribuição).

$2^{\circ}$ - Obter os fatores de emissão $\left(\mathrm{EF}_{\mathrm{j}}\right)$ para cada sistema de tratamento por meio da equação (2).

$E F_{j}=B_{0} \times M C F_{j}$

Em que,

$\mathrm{EF}_{\mathrm{j}}=$ fatores de emissão $\left(\mathrm{gCH}_{4} \cdot \mathrm{gDQO}^{-1}\right)$;

$\mathrm{B}_{0}=$ capacidade máxima de produção de $\mathrm{CH}_{4}\left(\mathrm{gCH}_{4} \mathrm{gDQO}^{-1}\right)$;

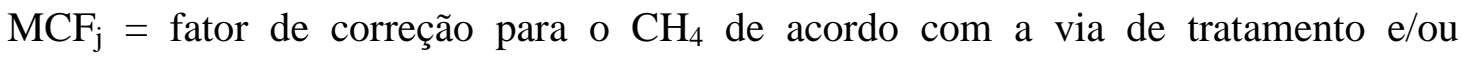
destinação final;

$\mathrm{j}=$ sistemas de tratamento e/ou destinação final.

$3^{\circ}$ - Estimar as emissões, subtraindo a quantidade de $\mathrm{CH}_{4}$ recuperado e destruído por combustão por meio da Equação (3). 
EmissõesCH$H_{4}=\left[\sum_{i, j}\left(U_{i} \times T_{i, j} \times E F_{j}\right)\right] \times(T O W-S)-R$

Em que,

Emissões $\mathrm{CH}_{4}=$ emissões de $\mathrm{CH}_{4}$ durante o ano $\left(\mathrm{kgCH}_{4} \cdot \mathrm{ano}^{-1}\right)$;

TOW = Total de matéria orgânica $\left(\mathrm{kgDQO} \cdot \mathrm{ano}^{-1}\right)$;

$S=$ matéria orgânica convertida em lodo $\left(\mathrm{kgDQO} \cdot \mathrm{ano}^{-1}\right)$;

$U_{i}=$ fração da população para cada grupo i;

$T_{i, j}=$ grau de utilização da via de tratamento e/ou eliminação j para cada grupo i;

$i=$ grupos de acordo com a renda: rural, urbano de alta renda e urbano de baixa renda;

$j$ = cada via de tratamento e/ou eliminação;

$E F_{j}=$ fator de emissão $\left(\mathrm{kgCH}_{4} \cdot \mathrm{kgDQO}^{-1}\right)$;

$R=\mathrm{CH}_{4}$ recuperado $\left(\mathrm{kgCH}_{4} \cdot \mathrm{ano}^{-1}\right)$.

De acordo com o IPCC (2006), a capacidade máxima de produção teórica de $\mathrm{CH}_{4}\left(\mathrm{~B}_{\mathrm{o}}\right)$, em termos de DQO e DBO, são iguais a 0,60 $\mathrm{gCH}_{4} \cdot \mathrm{gDBO}_{\text {remov }}{ }^{-1}, 0,25 \mathrm{gCH}_{4} \cdot \mathrm{gDQO}_{\text {remov }}{ }^{-1} \mathrm{e}$ $0,12 \mathrm{gCH}_{4} \cdot \mathrm{gDQO}_{\mathrm{afl}}{ }^{-1}$. Já o fator de correção $\mathrm{MCF}_{\mathrm{j}}$ varia de 0 a 1 de acordo com a via de tratamento e/ou destinação final Para reatores UASB sem recuperação do $\mathrm{CH}_{4}$ este valor é igual a 0,8. A abordagem teórica do IPCC para o fator de emissão (EF) pressupõe que toda fração orgânica removida anaerobiamente é convertida em $\mathrm{CH}_{4}$, sendo baseada na reação global estequiométrica para metanogênese em que os principais reagentes são a fração orgânica e a água, e os principais produtos incluem o $\mathrm{CH}_{4}$ e o $\mathrm{CO}_{2}$. É uma estimativa muito simplificada do complexo processo de degradação anaeróbia. Ressalta-se que as equações propostas não consideram as parcelas da DQO convertida em $\mathrm{CH}_{4}$, perdida dissolvida no efluente e com os gases residuais, nem a parcela de DQO utilizada na redução do sulfato. Essas parcelas são essenciais para o balanço de massa de DQO em reatores UASB e, portanto, devem ser consideradas para estimativas mais precisas das emissões de $\mathrm{CH}_{4}$ (Lobato, 2011). Ainda assim, segundo estimativa realizada por Salomon e Lora (2009), com base nas informações do IPCC, a produção anual estimada de metano proveniente do tratamento anaeróbio de esgoto no Brasil é da ordem de $50 \mathrm{Gg} \mathrm{CH}_{4} \cdot \mathrm{ano}^{-1}$.

Outros estudos apresentam valores diferentes para o fator de emissão, em estudo de campo limitado, Orlich (1990) obteve 0,22 $\mathrm{gCH}_{4} \cdot \mathrm{gDQO}_{\text {remov }}{ }^{-1}$, enquanto Toprak (1995 apud EL-FADEL, M. \& MASSOUD, 2001), em testes de campo obteve $0,10 \mathrm{gCH}_{4} \cdot \mathrm{gDQO}_{\text {remov }}{ }^{-1}$. 
Especificamente em reatores UASB (escala piloto) alimentados por esgoto doméstico, Souza, Chernicharo e Melo (2010) obtiveram o fator de emissão global de 0,12 $\mathrm{gCH}_{4} \cdot \mathrm{gDQO}_{\mathrm{afl}}^{-1}$ e $0,19 \mathrm{gCH}_{4} \cdot \mathrm{gDQO}_{\text {remov }}^{-1}$.

Considerando as emissões devido ao $\mathrm{CH}_{4}$ dissolvido no efluente dos reatores UASB, Cakir e Stenstrom (2005) concluíram que em reatores com baixas concentrações afluentes de matéria orgânica, o impacto da parcela de metano dissolvida no efluente pode ser tão grande quanto às emissões provenientes do metano recuperado no biogás. No entanto, em altas concentrações afluentes de matéria orgânica, o processo anaeróbio produz valores insignificantes para emissões de $\mathrm{CO}_{2}$ equivalente, devido à possibilidade de recuperação de energia pela combustão do biogás.

5.2 Modelo de estimativa segundo UNFCCC (2013)

A Convenção-Quadro das Nações Unidas sobre a Mudança do Clima - UNFCCC (UNFCCC, 2013), desenvolveu uma metodologia para avaliação da linha base de emissão de $\mathrm{CO}_{2}$ para projetos de recuperação e utilização do metano produzido pelo tratamento de esgoto, este modelo, é tipicamente empregado em estudos sobre mecanismos de desenvolvimento limpo e é uma adaptação do método apresentado pelo IPCC e por sua vez apresenta o segundo modelo apresentado na Equação 4:

$$
\begin{gathered}
B E_{w w, \text { treatment }, y}= \\
\sum_{i}\left(Q_{w w, i, j} x C O D_{\text {inf low }, i, j} x \eta_{C O D, B L, i} x M C F_{w w, \text { treatment }, B L, i}\right) x B_{0, w w} x U F_{B L} x G W P_{C H_{4}}
\end{gathered}
$$

Em que,

$B E_{w w, t r e a t m e n t, y}=$ Emissões de metano pelo sistema de tratamento de esgoto no ano y $\left(\mathrm{tCO}_{2 \mathrm{eq}}\right)$

$Q_{w w, i, j}=$ volume do esgoto tratado ( $\left.\mathrm{m}^{3} / \mathrm{ano}\right) ;$

$C O D_{\text {inf } l o w, i, j}=$ DQO do afluente $\left(\mathrm{t} / \mathrm{m}^{3} / \mathrm{ano}\right)$;

$\eta_{C O D, B L, i}=$ eficiência de remoção da DQO;

$M C F_{w w, t r e a t m e n t, B L, i}=$ fator de correção do metano, conforme IPCC (2006);

$B_{0, w w}=$ capacidade de produção do metano do esgoto, conforme IPCC (2006); 
$U F_{B L}=$ fator de correção para as incertezas $(0,89)$;

$G W P_{C_{4}}=$ potencial de aquecimento global do metano.

Em ambos os modelos, para se obter a produção volumétrica de metano, aplicou-se a Equação 5.

$$
E_{C H_{4}}=\frac{\mathrm{CH}_{4 E m i s s i o n s}}{\rho_{C H_{4}}}
$$

Em que,

$E_{\mathrm{CH}_{4}}=$ emissão de $\mathrm{CH}_{4}\left(\mathrm{~m}^{3} \mathrm{CH}_{4} /\right.$ dia $)$;

$\mathrm{CH}_{4 \text { Emissions }}=$ Emissão de $\mathrm{CH}_{4}\left(\mathrm{~kg} \mathrm{CH}_{4} /\right.$ dia $)$;

$\rho_{\mathrm{CH}_{4}}=$ densidade do metano $\left(0,717 \mathrm{~kg} / \mathrm{m}^{3}\right)$.

5.3 Modelo matemático para cálculo do balanço de massa da DQO segundo Chernicharo (1997)

O método desenvolvido por Chernicharo (1997), faz uso da relação estequiométrica entre os reagentes do processo anaeróbio, conforme detalhado no artigo de Borges et al (2009). A produção de metano, em $\mathrm{m}^{3} /$ ano, é dada pelas equações 6 e 7.

$$
V_{C H_{4}}=\frac{D Q O_{C H_{4}}}{K(t)}
$$

Em que,

$V_{\mathrm{CH}_{4}}=$ volume de metano produzido (L);

$\mathrm{DQO}_{\mathrm{CH}_{4}}=$ carga de DQO removida no reator e convertida em metano (gDQO);

$K(t)=$ fator de correção para a temperatura operacional do reator (gDQO/L).

$$
K(t)=\frac{P \times K}{R X(273+t)}
$$


Em que,

$P=$ pressão atmosférida $(1 \mathrm{~atm})$;

$K=$ fator de correção para a temperatura operacional do reator $\left(\mathrm{kgDQO} / \mathrm{m}^{3}\right)$

$R=$ constante dos gases $\left(0,08206 \mathrm{~atm} . \mathrm{L} / \mathrm{mol} .{ }^{\circ} \mathrm{K}\right)$;

$t=$ temperatura operaional do reator $\left({ }^{\circ} \mathrm{C}\right)$.

A carga de DQO removida no reator e convertida em metano é dada pela Equação 8:

$D Q O_{C H_{4}}=Q_{m e ́ d}\left[\left(S_{0}-S\right)-\left(\left(Y_{\text {obs }} x K_{\text {sólidos }}\right) x\left(S_{0}-S\right)\right)\right]$

Em que,

$D Q O_{C_{4}}=$ carga de DQO convertida em metano $\left(\mathrm{kgDQOCH}_{4} / \mathrm{d}\right)$;

$Q_{m e ́ d}=$ vazão média de esgoto afluente $\left(\mathrm{m}^{3} / \mathrm{dia}\right)$;

$S_{0}=$ concentração de DQOtotal afluente $\left(\mathrm{kgDQO} / \mathrm{m}^{3}\right)$;

$S=$ concentração de DQOtotal afluente $\left(\mathrm{kgDQO} / \mathrm{m}^{3}\right)$

$Y_{o b s}=$ coeficiente de produção de sólidos no sistema (kgSVT/kgDQOremovida);

$K_{\text {sólidos }}=$ fator de conversão de STV em DQO (1,42 kgDQO/kgSVT).

5.4 Modelo matemático para cálculo do balanço de massa da DQO e do potencial energético segundo Lobato (2011)

Lobato (2011) apresenta um modelo matemático para o cálculo do balanço de massa da DQO e do potencial energético conceitualmente estruturado de acordo com as rotas de conversão de DQO e fluxos de metano em reatores UASB representados na Figura 18. São estimadas as parcelas de DQO removida no sistema, convertida em lodo e consumida na redução do sulfato. Com essas parcelas calcula-se a DQO máxima convertida em $\mathrm{CH}_{4}$ e a consequente produção volumétrica máxima. A fim de se calcular o volume de $\mathrm{CH}_{4}$ realmente disponível para o aproveitamento energético, o modelo considera as perdas de $\mathrm{CH}_{4}$ dissolvido no efluente e na fase gasosa com o gás residual, além de outras perdas eventuais na fase gasosa. Por fim, descontadas essas perdas, o potencial energético disponível é calculado. $\mathrm{O}$ 
modelo conta ainda com análise de incerteza que se baseou na execução de um elevado número de simulações

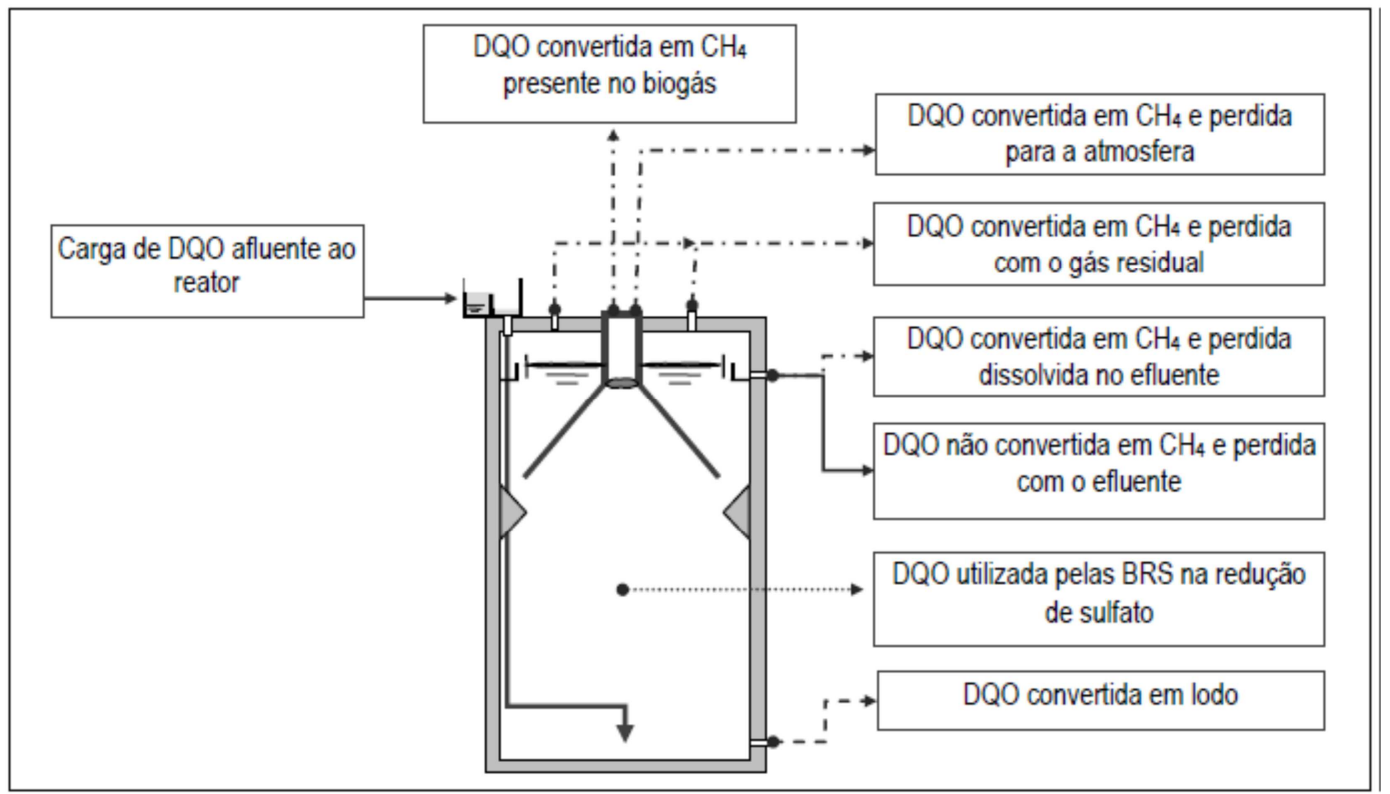

Figura 18 - Rotas de conversão de DQO e fluxos de metano em reatores UASB

Fonte: Lobato, 2011.

O modelo matemático considera três situações que acarretam em potenciais de recuperação de metano diferentes:

- pior situação: com potencial energético menor, refere-se a sistemas operando com esgoto mais diluído, concentrações de sulfato maiores, menor eficiência de remoção de DQO e maiores índices de perda de metano;

- situação típica: para a situação típica são utilizados valores intermediários para os dados de entrada.

- melhor situação: o potencial energético é maior, refere-se a sistemas operando com esgoto mais concentrado, menores concentrações de sulfato, maior eficiência de remoção de DQO e menores índices de perda de metano.

As equações utilizadas para os cálculos de todas as parcelas do balanço de massa da DQO e do potencial de recuperação de energia são apresentadas a seguir.

Para estimar a carga de DQO removida no sistema há duas Equações, 9 e 10.

$$
D Q O_{\text {remov }}=P o p \times Q P C_{D Q O} \times \frac{E_{D Q O}}{100}
$$


Em que,

$D Q O_{\text {remov }}=$ massa diária de DQO removida no sistema $\left(\mathrm{kgDQO}_{\text {remov }} \cdot \mathrm{d}^{-1}\right)$;

Pop = população contribuinte;

$Q P C_{D Q O}=$ contribuição per capita de DQO $\left(\operatorname{kgDQO} \cdot \mathrm{hab}^{-1} \cdot \mathrm{d}^{-1}\right)$;

$E_{D Q O}=$ eficiência de remoção de DQO (\%).

$E_{D Q O}=\frac{C_{D_{Q O t o t a} a f l}-C_{D Q O s o l}^{e f l}}{C_{D_{Q O t o t a}}{ }_{a f l}}$

Em que,

$C_{\text {DQOtot afl }}=$ concentração de DQO total afluente,

$C_{D Q O s o l ~ e f l}=$ concentração de DQO solúvel no efluente .

Para estimar a produção de lodo em reatores UASB também há duas Equações $11 \mathrm{e}$ 12.

$D Q O_{\text {lodo }}=Y_{\text {obs }} \times D Q O_{\text {remov }}$

Em que,

$D Q O_{\text {lodo }}=$ massa diária de DQO convertida em lodo $\left(\mathrm{kgDQO}_{\text {lodo. }} \cdot \mathrm{d}^{-1}\right)$,

$D Q O_{\text {remov }}=$ massa diária de DQO removida no sistema $\left(\mathrm{kgDQO}_{\mathrm{remov}} \cdot \mathrm{d}^{-1}\right)$,

$Y_{o b s}=$ coeficiente de produção de sólidos $\left(\mathrm{kgDQO}_{\text {lodo }} \cdot \mathrm{kgDQO}_{\text {remov }}{ }^{-1}\right)$.

$Y_{\text {obs }}=Y \times K_{\text {sólidos }}$

Em que,

$Y=$ coeficiente de produção de sólidos em termos de DQO $\left(0,15 \mathrm{kgSTV}^{-1}\right.$.

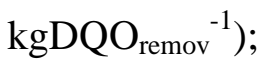

$K_{\text {sólidos }}=$ fator de conversão de STV em DQO (1,42 kgDQOlodo.kgSVT $\left.{ }^{-1}\right)$.

Ressalta-se que a DQO convertida em lodo pode ser dividida em duas parcelas: (i) DQO convertida em lodo, retida no sistema e/ou retirada com o lodo excedente e (ii) DQO convertida em lodo e perdida junto ao efluente.

A estimativa da carga de sulfato reduzida a sulfeto pode ser realizada por meio da Equação 13. 
$\mathrm{CO}_{\mathrm{SO}_{4} \text { convertida }}=Q_{\text {méd }} \times C_{\mathrm{SO}_{4}^{-}} \times \frac{E_{S_{4}}}{100}$

Em que,

$\mathrm{CO}_{\text {SO4convertida }}=$ carga de $\mathrm{SO}_{4}$ convertida em sulfeto $\left(\mathrm{kgSO}_{4} \cdot \mathrm{d}^{-1}\right)$;

$Q_{m e ́ d}=$ vazão média de esgoto afluente ao reator $\left(\mathrm{m}^{3} \cdot \mathrm{d}^{-1}\right)$;

$C_{\mathrm{SO} 4}=$ concentração média de $\mathrm{SO}_{4}$ no afluente $\left(\mathrm{kgSO}_{4} \cdot \mathrm{m}^{-3}\right)$;

$E_{S O 4}=$ eficiência de redução de $\mathrm{SO}_{4}(\%)$.

A estimativa da carga de DQO utilizada na redução de sulfato pode ser realizada pela Equação 14.

$$
\mathrm{DQO}_{\mathrm{SO}_{4}}=D Q O_{\text {remov }} \times C_{\mathrm{SO}_{4} \text { convertida }} \times K_{D Q O-\mathrm{SO}_{4}}
$$

Em que,

$D Q O_{S O 4}=$ massa diária de DQO utilizada pela BRS na redução de sulfato;

$K_{D Q O-S O 4}=$ DQO consumida na redução de sulfato $\left(0,667 \mathrm{KgDQO} / \mathrm{kgSO}_{4}\right.$ convertido $)$.

A expressão geral que determina a produção teórica máxima de metano por grama de DQO removida do despejo é como a seguir:

$Q_{C H_{4}}=\frac{D_{Q O} \mathrm{CH}_{4} \times R \times(273+T)}{P \times K_{D Q O} \times 1000}$

Em que,

$Q_{C H 4}=$ produção volumétrica teórica máxima de metano $\left(\mathrm{m}^{3} \cdot \mathrm{d}^{-1}\right)$,

$D Q O_{C H 4}=$ massa diária de DQO convertida em metano $\left(\mathrm{kgDQO} \cdot \mathrm{d}^{-1}\right)$,

$P=$ pressão atmosférica $(1 \mathrm{~atm})$,

$K_{D Q O}=$ DQO correspondente a um mol de $\mathrm{CH}_{4}\left(0,064 \mathrm{kgDQO}_{\mathrm{CH} 4} \cdot \mathrm{mol}^{-1}\right)$,

$R=$ constante dos gases $\left(0,08206 \mathrm{~atm} \cdot \mathrm{L} \cdot \mathrm{mol}^{-1} \cdot \mathrm{K}^{-1}\right)$,

$T=$ temperatura operacional do reator $\left({ }^{\circ} \mathrm{C}\right)$.

A determinação da massa diária de DQO convertida em $\mathrm{CH}_{4}$ pode ser calculada por meio da Equação 16. 


$$
D Q O_{C_{4}}=D Q O_{r e m}-D Q O_{l o d o}-D Q O_{S O_{4}^{2-}}
$$

A partir da produção volumétrica de $\mathrm{CH}_{4}$, pode-se estimar a produção total de biogás, a partir do teor esperado, de acordo com a Equação 17.

$$
Q_{\text {biogás }}=\frac{Q_{C H_{4}}}{C_{C_{4}}}
$$

Em que,

$Q_{\text {biogás }}=$ produção volumétrica de biogás $\left(\mathrm{m}^{3} \cdot \mathrm{d}^{-1}\right)$;

$C_{C H 4}=$ concentração de metano no biogás $(\%)$.

A Equação 17 representa a produção volumétrica máxima de metano, não levando em consideração as perdas de $\mathrm{CH}_{4}$ dissolvido no efluente ou no gás residual e, também, outras perdas, como vazamentos, purgas de condensado, etc. Quando o intuito do balanço de massa da DQO é estimar o volume de metano efetivamente coletado no interior do separador trifásico e disponível para recuperação de energia, é importante considerar essas perdas a fim de se obter valores mais reais. Para a determinação das perdas de metano foram utilizadas as Equações 18, 19 e 20.

$$
\begin{aligned}
& Q_{W-C H_{4}}=Q_{C H_{4}} \times P_{w} \\
& Q_{0-C H_{4}}=Q_{C H_{4}}-p_{0} \\
& Q_{L-C H_{4}}=\frac{Q_{m e ́ d} \times p_{L} \times f_{C H_{4}}}{f(T)}
\end{aligned}
$$

Em que,

$Q_{W-C H 4}=$ perda de metano na fase gasosa, com o gás residual $\left(\mathrm{m}^{3} \cdot \mathrm{d}^{-1}\right)$;

$p_{w}=$ percentual de perda de metano na fase gasosa, com o gás residual (\%);

$Q_{O-C H 4}=$ outras perdas de metano na fase gasosa $\left(\mathrm{m}^{3} \cdot \mathrm{d}^{-1}\right)$;

$p_{\mathrm{O}}=$ percentual de outras perdas de metano na fase gasosa $(\%)$;

$Q_{L-C H 4}=$ perda de metano na fase líquida, dissolvido no efluente $\left(\mathrm{m}^{3} \cdot \mathrm{d}^{-1}\right)$; 
$p_{\mathrm{L}}=$ perda de metano na fase líquida, dissolvido no efluente $\left(\mathrm{kg} \cdot \mathrm{m}^{-3}\right)$;

$f_{\mathrm{CH} 4}=$ fator de conversão de massa de metano em massa de DQO (coeficiente estequiométrico 4,0 $\mathrm{kgDQO} \cdot \mathrm{kgCH}_{4}^{-1}$ ).

Uma vez calculada a produção teórica de metano e as parcelas referentes às perdas, é estimado o volume de metano efetivamente coletado no interior do separador trifásico e disponível para recuperação de energia. Os cálculos foram efetuados de acordo com a equação seguinte:

$Q_{R E A L-C H_{4}}=Q_{C H_{4}}-Q_{W-C_{4}}-Q_{0-C_{4}}-Q_{L-C H_{4}}$

Em que,

$Q_{R E A L-C H 4}=$ produção real de metano disponível para recuperação de energia $\left(\mathrm{m}^{3} \cdot \mathrm{d}^{-1}\right)$

A estimativa do potencial energético disponível no biogás efetivamente coletado pelo separador trifásico foi feita conforme a seguinte equação:

$P E_{R E A L-C H_{4}}=Q_{N-R E A L-C H_{4}} \times E_{C H_{4}}$

na qual:

$\mathrm{PE}_{\mathrm{REAL}-\mathrm{CH} 4}=$ potencial energético disponível $\left(\mathrm{MJ}_{\mathrm{d}} \mathrm{d}^{-1}\right)$

$\mathrm{Q}_{\mathrm{N}-\mathrm{REAL}-\mathrm{CH} 4}=$ produção real normalizada de metano $\left(\mathrm{Nm}^{3} \cdot \mathrm{d}^{-1}\right)$

$\mathrm{E}_{\mathrm{CH} 4}=$ poder calorífico superior decorrente da combustão do metano (35,9 MJ.Nm$\left.{ }^{-3}\right)$

Segundo Lobato (2011) as simulações utilizando o modelo matemático desenvolvido foram efetuadas, para reatores UASB tratando esgoto tipicamente doméstico, com o intuito de se estimar as faixas esperadas de produção de biogás e do potencial de geração de energia disponível para utilização.

Esse método considera todas as parcelas envolvidas na digestão anaeróbia e as possíveis perdas possibilitam a obtenção de valores para a produção teórica de $\mathrm{CH}_{4}$ coletado e disponível para recuperação de energia mais próximos dos valores reais medidos em campo. 
No entanto, esse modelo foi validado a partir dos resultados obtidos em reatores em escala piloto e demonstração, onde as condições operacionais são mais facilmente controladas.

Os resultados das simulações deste método apontaram para o fato de que parcelas significativas da DQO afluente ao sistema podem não ser recuperadas como metano no biogás, e ainda de acordo com Lobato (2011) os resultados dependeram, principalmente, das perdas de metano dissolvido no efluente e da concentração de sulfato no afluente. Para a pior situação, apenas 19\% da DQO afluente foi recuperada como metano no biogás. Para a melhor situação, o percentual de recuperação de metano no biogás atingiu 39\% da DQO afluente ao reator. De toda a DQO convertida em metano, a parcela recuperada no biogás variou de 50 a $75 \%$, a depender das perdas mencionadas anteriormente (LOBATO, 2011).

Ainda segundo Lobato (2011), com base nas simulações efetuadas, foram obtidas, ainda, as seguintes relações unitárias de produção de metano, de biogás e de energia em reatores UASB tratando esgoto tipicamente doméstico (Tabela 7).

Tabela 7 - Relações unitárias de produção de metano, de biogás e de energia em reatores UASB tratando esgoto doméstico.

\begin{tabular}{|c|c|c|c|c|c|c|c|c|c|c|}
\hline \multirow{2}{*}{$\begin{array}{l}\text { Relação } \\
\text { unitária }\end{array}$} & \multirow[t]{2}{*}{ Unidade } & \multicolumn{3}{|c|}{ Pior situação } & \multicolumn{3}{|c|}{ Situação típica } & \multicolumn{3}{|c|}{ Melhor situação } \\
\hline & & Máx & Mín & Méd & Máx & Mín & Méd & Máx & Mín & Méd \\
\hline \multirow{3}{*}{$\begin{array}{c}\text { Volume } \\
\text { unitário de } \\
\qquad \mathrm{CH}_{4} \\
\text { produzido }\end{array}$} & $\mathrm{NL} \mathrm{hab}^{-1} \cdot \mathrm{dia}^{-1}$ & 9,9 & 3,6 & 6,8 & 13,3 & 7,4 & 10,2 & 16,7 & 11,1 & 13,7 \\
\hline & NL. $\mathrm{m}^{-3}$ esgoto & 81,7 & 16,7 & 42,2 & 103,7 & 34,8 & 64,2 & 134,6 & 51,8 & 81,3 \\
\hline & NL.kgDQO remov $^{-1}$ & 154,1 & 66 & 113,4 & 185,8 & 124,2 & 158,3 & 219,1 & 173,9 & 196 \\
\hline \multirow{3}{*}{$\begin{array}{c}\text { Volume } \\
\text { unitário de } \\
\text { biogás } \\
\text { produzido }\end{array}$} & NL.hab ${ }^{-1} \cdot$ dia $^{-1}$ & 14,1 & 5,2 & 9,8 & 17,7 & 9,9 & 13,6 & 20,8 & 13,9 & 17,1 \\
\hline & NL.m ${ }^{-3}$ esgoto & 116,7 & 23,8 & 60,3 & 138,3 & 46,4 & 85,6 & 168,3 & 64,8 & 101,6 \\
\hline & NL.kgDQO remov $^{-1}$ & 220,1 & 94,3 & 162 & 247,8 & 165,6 & 211,1 & 273,9 & 217,4 & 245 \\
\hline \multirow{8}{*}{$\begin{array}{c}\text { Potencial } \\
\text { energético } \\
\text { unitário }\end{array}$} & $\mathrm{kWh} \cdot \mathrm{m}^{-3}$ esgoto & 0,8 & 0,2 & 0,4 & 1 & 0,3 & 0,6 & 1,3 & 0,5 & 0,8 \\
\hline & $\begin{array}{c}\mathrm{kWh} \cdot \mathrm{kgDQO}_{1} \\
\text { remov }\end{array}$ & 1,5 & 0,7 & 1,1 & 1,9 & 1,2 & 1,6 & 2,2 & 1,7 & 2 \\
\hline & kWh.Nm ${ }^{-3}$ biogás & 7 & 7 & 7 & 7,5 & 7,5 & 7,5 & 8 & 8 & 8 \\
\hline & kWh.hab ${ }^{-1} \cdot$ ano $^{-1}$ & 36 & 13,2 & 24,9 & 48,3 & 26,9 & 37,2 & 60,7 & 40,5 & 49,8 \\
\hline & MJ.m ${ }^{-3}$ esgoto & 2,9 & 0,6 & 1,5 & 3,7 & 1,2 & 2,3 & 4,8 & 1,9 & 2,9 \\
\hline & MJ.kgDQO $_{\text {remov }}^{-1}$ & 5,5 & 2,4 & 4,1 & 6,7 & 4,5 & 5,7 & 7,9 & 6,2 & 7 \\
\hline & MJ.Nm ${ }^{-3}$ biogás & 25,1 & 25,1 & 25,1 & 26,9 & 26,9 & 26,9 & 28,7 & 28,7 & 28,7 \\
\hline & MJ.hab $^{-1}$.ano & 129,5 & 47,7 & 89,7 & 173,8 & 96,8 & 133,8 & 218,4 & 145,7 & 179,3 \\
\hline
\end{tabular}




\subsection{Modelos de estimativa segundo CETESB (2006)}

A CETESB (2006) apresentou um programa de computador com o objetivo de auxiliar a viabilidade do uso energético do biogás gerado pela degradação de efluentes. O programa apresenta dois diferentes métodos que empregam fatores de geração de efluentes para fontes urbanas, rurais e industriais, fatores de produção de biogás para cada um desses efluentes e concentração de metano. A escolha desses métodos se deve à simplicidade para a aplicação e à desejada maior confiança nos seus resultados, devido à sua popularidade.

Os dois modelos para a estimativa de geração de biogás em ETEs anaeróbias: um baseado na matéria total gerada pela população local (Equação 23) e outro baseado na geração de matéria orgânica (Equação 24):

$$
\begin{aligned}
Q_{i} & =30 \times \frac{\sum\left(P b_{i} \times \operatorname{Conc}_{i} \times Q_{t_{i}} \times M t\right)}{V E} \\
Q_{i} & =\frac{\left(30 \times P_{i} \times f D B O_{5} \times M F P M \times E f\right)}{V E}
\end{aligned}
$$

Em que,

$Q_{i}=$ Vazão de metano $\left[\mathrm{m}^{3} \mathrm{CH}_{4} / \mathrm{mês}\right]$,

$P b_{i}=$ produção de biogás [0,001 kg biogás $\left./ \mathrm{kg} \mathrm{Mt}\right]$,

Conc $_{i}=$ concentração de metano no biogás [60\%],

$Q t_{i}$ : Quantidade de unidades geradoras de efluente [unidade geradora],

$M t=$ matéria total enviada ao esgoto por habitante a cada dia $[150 \mathrm{~kg}]$,

$V E=$ Massa específica do Metano $\left[0,670 \mathrm{~kg}_{\mathrm{CH}_{4}} / \mathrm{m}_{\mathrm{CH}_{4}}^{3}\right]$,

$P i=$ Unidades $/$ dia $=$ população $/$ dia,

$f \mathrm{DBO}_{5}=$ fator de emissão de DBO típico $\left[\mathrm{kgDBO}_{5} / \mathrm{unidade}\right]$,

$M F P M=$ máximo fator de produção de metano $\left[0,25 \mathrm{~kg}_{\mathrm{CH}_{4}} / \mathrm{kg} \mathrm{DBO}\right]$,

$E f=$ eficiência do tratamento [\%]. 
O programa de computador é um dos produtos de um convênio firmado entre a CETESB - Companhia de Tecnologia de Saneamento Ambiental, a Secretaria do Meio Ambiente do Estado de São Paulo - SMA-SP e o Ministério da Ciência e Tecnologia - MCT, cujo objetivo foi a elaboração de manuais para a orientação do uso energético de biogás e fomento da formação de centros para o desenvolvimento dessa atividade no Brasil. 


\section{METODOLOGIA ADOTADA PARA EXECUÇÃO DO TRABALHO}

6.1 Parâmetros operacionais da ETE Atuba Sul.

A ETE Atuba Sul foi selecionada para o levantamento de dados operacionais e para instalação dos equipamentos de medição de vazão do biogás.

A ETE Atuba Sul (Figura 19) localiza-se no município de Curitiba, e está inserida na bacia hidrográfica do rio Atuba, na margem direita do mesmo rio, como pode ser visto no mapa de localização ilustrado na Figura 20. A ETE Atuba Sul iniciou a sua operação em 1998 e, atualmente, sua capacidade nominal de tratamento de esgoto é de $1.120 \mathrm{~L} / \mathrm{s}$. O sistema de esgotamento sanitário da ETE Atuba Sul é do tipo separador absoluto, possuindo 118.668 ligações, coletando e tratando o esgoto de cerca de 420.000 pessoas dos municípios de Piraquara, Pinhais, São José dos Pinhais, Colombo, Almirante Tamandaré e Curitiba.

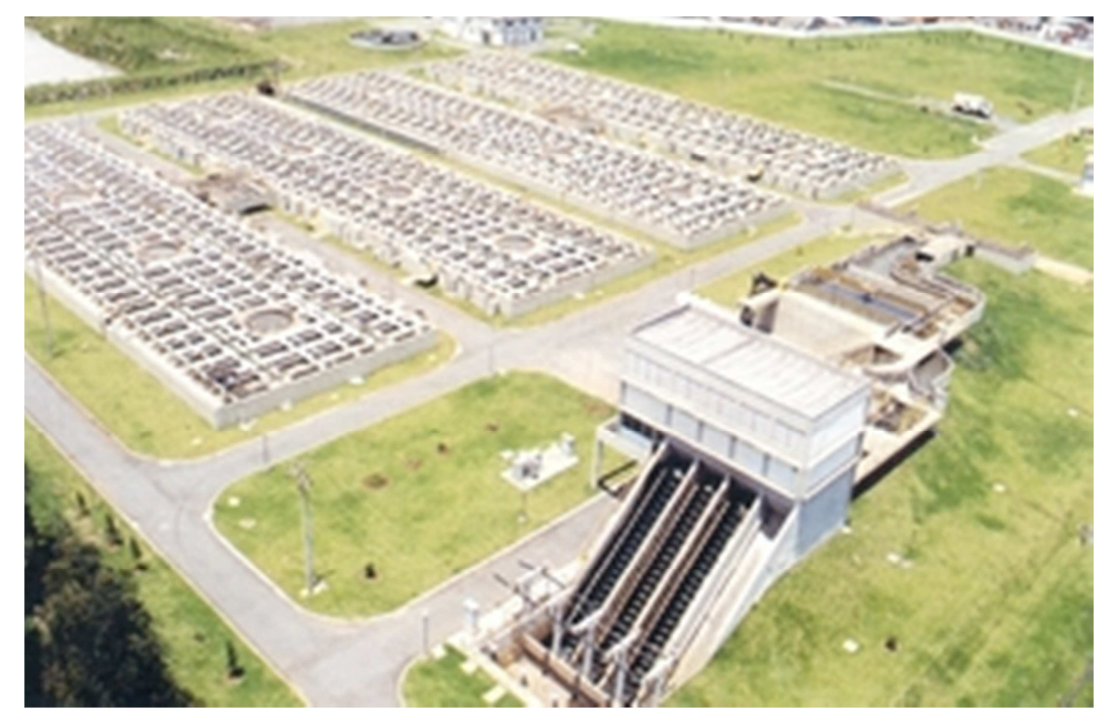

Figura 19 - Vista geral da ETE Atuba Sul

Fonte: Franco (2010 p. 144). 


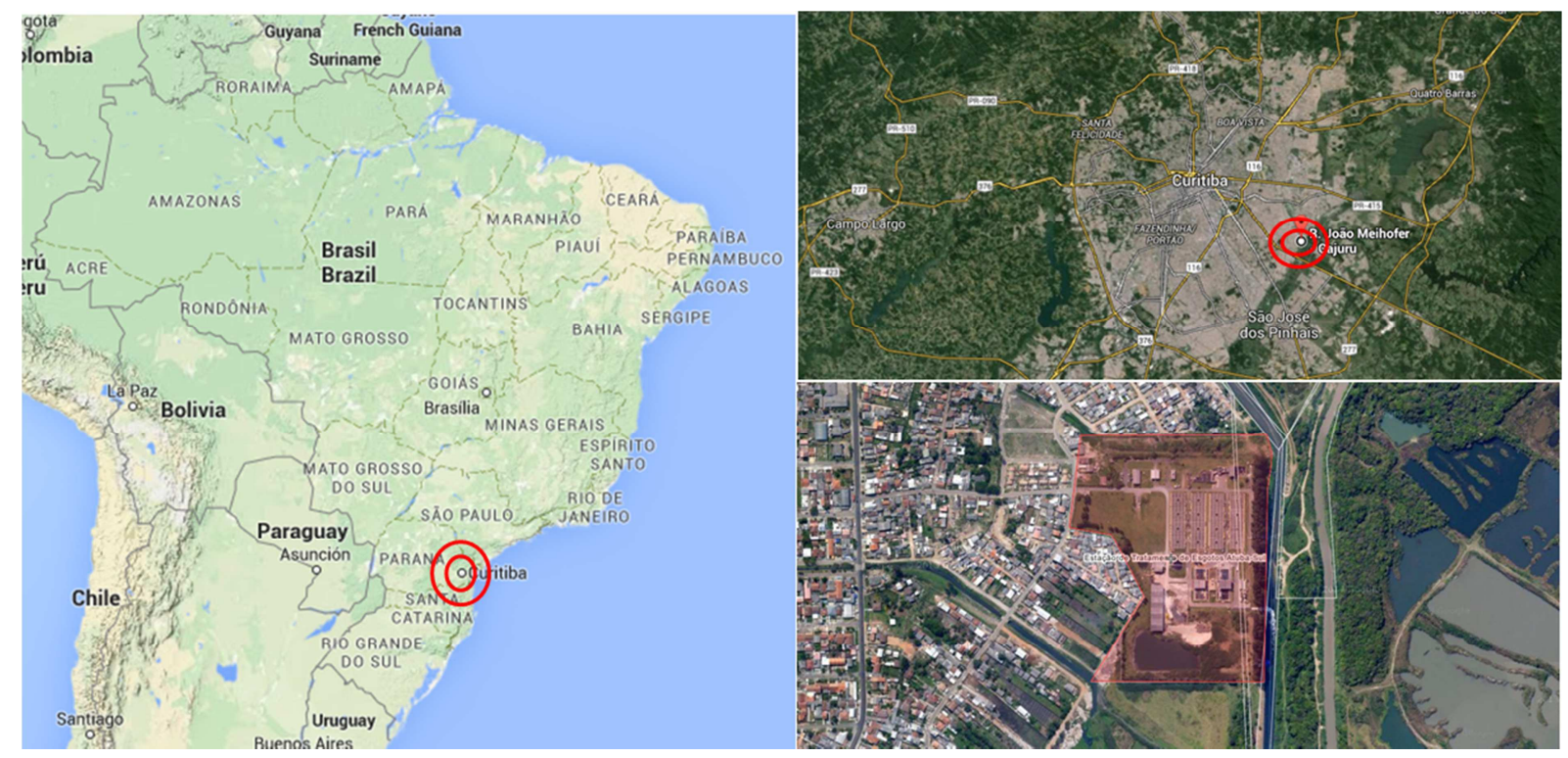

Figura 20 - Mapa de localização da ETE Atuba Sul

Fonte: Adaptado de Google Earth (2014).

A ETE Atuba Sul é constituída pelas seguintes unidades operativas: estação elevatória de esgoto, sistema de gradeamento mecanizado, desarenador, calha parshal com sensor ultrassônico para medição da vazão de esgoto, caixa de distribuição de vazão, que tem a finalidade de distribuir a vazão por igual em todas as linhas dos 16 reatores UASB, cada um com volume útil de $2.000 \mathrm{~m}^{3}, 70 \mathrm{~L} / \mathrm{s}$ de vazão média e dispostos em 4 linhas de 4 reatores. Após o tratamento nos reatores, o efluente líquido é conduzido ao processo de floculação e flotação, de onde segue para o lançamento no corpo hídrico receptor.

O excesso de lodo é descarregado do fundo dos reatores em poços laterais, por gravidade, mediante a abertura de válvulas de descarga. O biogás formado no processo de biodegradação anaeróbia é armazenado no gasômetro dos reatores e conduzido, por meio de tubulações à queimadores com acendimento contínuo e automático providos de válvula cortachamas de segurança. No poço, onde os lodos do reator foram descarregados, uma bomba submersa de baixa rotação conduz o lodo ao adensador de lodos. O lodo segue, então, para o processo de secagem, constituído por centrífugas e pátio de cura. O lodo depois de seco e caleado pode ser então encaminhado para reciclagem agrícola. A Figura 21 demonstra o 
fluxograma do processo de tratamento.

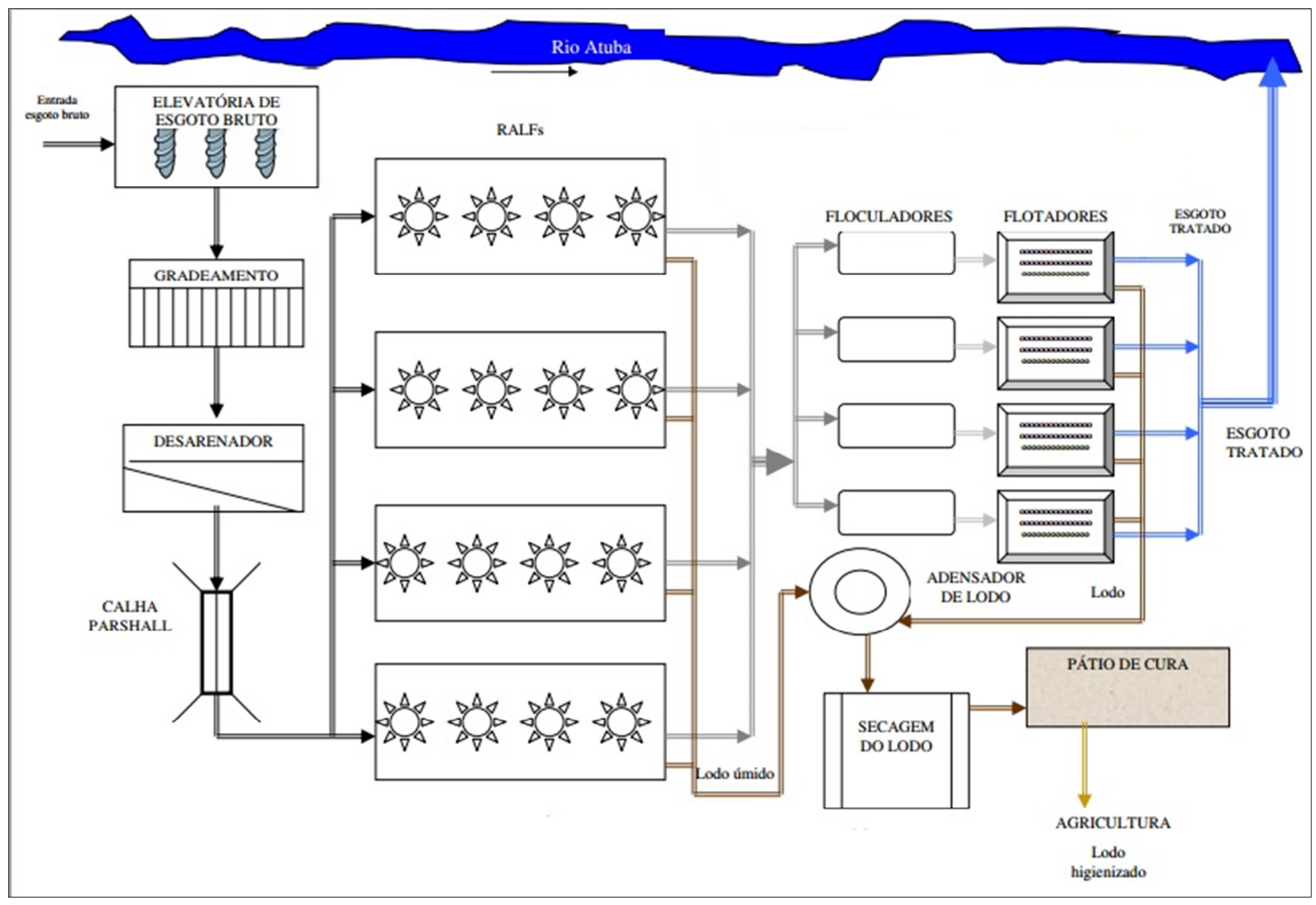

Figura 21 - Fluxograma do processo de tratamento da ETE Atuba Sul

Fonte: Adaptado de Franco (2010).

Para este estudo, foram disponibilizados dados de 83 dias do controle operacional da ETE Atuba Sul, dentro do período de 01 de outubro de 2011 a 01 de outubro de 2012. Esses dados foram coletados com intervalos aproximadamente semanais, compreendendo os parâmetros físico e químicos que fazem parte da rotina operacional da ETE, como segue:

- Dados do esgoto afluente: vazão, temperatura, DQO, DBO, sólidos sedimentáveis, sólidos suspensos;

-Dados do esgoto efluente dos reatores: temperatura, DQO, DQO filtrada, DBO, sólidos sedimentáveis, sólidos suspensos;

Em seguida, foram avaliados a média e o desvio padrão destses dados, em seguida foram calculados a população equivalente, a carga orgânica e a eficiência do tratamento com relação aos parâmetros DQO e DBO. 
6.2 Quantificação em tempo real da vazão produzida de biogás e de metano

A quantificação em tempo em real da vazão produzida de biogás contemplou medições executadas nas instalações da ETE Atuba Sul e foram coletados os seguintes dados relativos ao biogás no período de 01 de outubro de 2011 a 01 de outubro de 2012:

- vazão;

- teor de metano

Para isso, foram utilizados os seguintes equipamentos:

Para medir o teor de metano presente no biogás foi utilizado um transmissor ótico seletivo, com resolução de $0,1 \%$ v/v, exatidão de $+/-2,5 \%$ v/v e repetitividade de $+/-2,0 \%$ v/v, operando na faixa do infravermelho (Guardian Plus, Edinburgh Sensors).

Para medir a vazão de biogás foi adotado um transmissor por dispersão térmica Thermathel $^{\circledR}$ (TA2, Magnetrol), com resoluções de $5,6 \mathrm{Nm}^{3} / \mathrm{h}$ e $0,1{ }^{\circ} \mathrm{C}$, exatidões de $+/-1,0$ $\mathrm{Nm}^{3} / \mathrm{h}$ e $+/-1,0{ }^{\circ} \mathrm{C}$ e repetibilidades de $+/-0,5 \%$ da leitura.

Os equipamentos foram alimentados eletricamente e acoplados a um quadro de comandos dedicado (Figura 22).

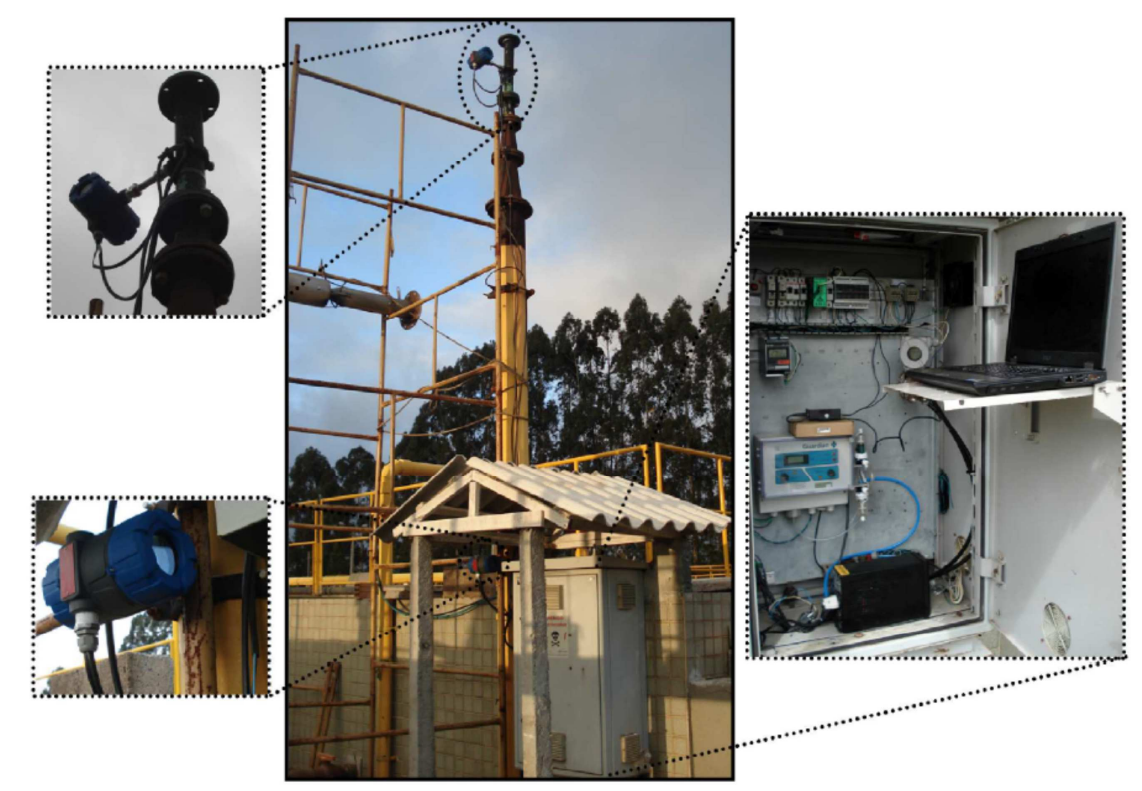

Figura 22 - Equipamentos utilizado para realização das medições em campo.

Fonte: Possetti et al. (2013).

Também foi utilizado um aquisidor de dados (A202, Contemp), que coletou e armazenou os sinais analógicos padrão 4-20 mA disponibilizados pelo equipamento em 
intervalos de 30 segundos. A leitura desses dados foi efetuada por um sistema supervisório (MasterLogger A202, Contemp) instalado em um computador portátil (Latitude, Dell). A fixação dos transmissores e a inserção das sondas nos tubos condutores de biogás foram executadas de acordo com as recomendações descritas em seus manuais (POSSETTI et al., 2013).

Nos testes realizados, foram adquiridos dados por meio de medições passivas de biogás em tempo real. Como tais medições foram realizadas no final de uma linha condutora de biogás que totalizava apenas a contribuição de 4 reatores UASB e como a ETE possui 16 reatores UASB semelhantes e com distribuição de vazão de esgoto supostamente iguais, a taxa média de produção de biogás e de metano reportada foi multiplicada por quatro.

\subsection{Avaliação da influência dos eventos de chuva na produção de biogás}

Para avaliar a influência dos eventos de chuva, foi utilizado os dados de precipitação disponibilizados pelo Banco de Dados Meteorológicos para Ensino e Pesquisa (BDMEP) disponibilizados pelo Instituto Nacional de Meteorologia (INMET) e compreendendo o período de 01 de outubro de 2011 a 01 de outubro de 2012.

O total de dias chuvosos foi classificado utilizando a metodologia de Sant'Anna Neto e Tommaselli (2009, p. 43) que consideram como sendo um dia com chuva aqueles com precipitação igual ou superior a $1 \mathrm{~mm}$ no decorrer de 24 horas, e Carvalho et al (2010) que consideram dias chuvosos aqueles com valores de precipitação pluvial igual ou superior a 1 $\mathrm{mm}$.

Para classificar os eventos de chuva foi utilizada uma adaptação da classificação de Bustamante (2010) que adota como critério da intensidade da chuva acumulada em 24 horas conforme pode ser visualizado na Tabela 8 .

Tabela 8 - Classificação da intensidade da chuva

\begin{tabular}{cc}
\hline Classificação & Precipitação $(\mathrm{mm} /$ dia $)$ \\
\hline Ausência & Igual a 0 \\
Chuvisco & Maior que 0 até $1 \mathrm{~mm}$ \\
Chuva fraca & Maior que $1 \mathrm{~mm}$ até $10 \mathrm{~mm}$ \\
Chuva moderada & Maior que $10 \mathrm{~mm}$ até $20 \mathrm{~mm}$
\end{tabular}




\begin{tabular}{cc}
\hline Classificação & Precipitação $(\mathrm{mm} /$ dia $)$ \\
\hline Chuva moderada a forte & Maior que $20 \mathrm{~mm}$ até $30 \mathrm{~mm}$ \\
Chuva forte & Maior que $30 \mathrm{~mm}$ até $40 \mathrm{~mm}$ \\
Chuva muito forte & Maior que $40 \mathrm{~mm}$ até $50 \mathrm{~mm}$ \\
Chuva extremamente forte & Acima de $50 \mathrm{~mm}$
\end{tabular}

Os dados de pluviosidade e vazão de biogás foram analisados e tratados de forma a considerar sempre a vazão de um dia em relação ao dia anterior. Em seguida foram selecionados os dados específicos em relação à:

- vazão média de biogás de um dia com chuva comparada à vazão de biogás do dia anterior;

- eventos de chuva em dias consecutivos, ou seja, considerando eventos de chuva que duraram dois ou mais dias ininterruptos, assim a vazão média de biogás do último dia do evento de chuva foi comparada à vazão média de biogás do último dia sem chuva;

- a vazão de biogás do primeiro dia após o evento de chuva com a vazão de biogás do dia anterior (com chuva).

Por fim estes dados foram analisados estatisticamente.

6.4 Estimativa do potencial de produção de biogás por meio de métodos reportados na literatura e comparação com os resultados de medições realizadas em campo

As taxas de produção de biogás gerado na ETE foram estimadas utilizando os dados dos parâmetros operacionais da ETE Atuba Sul e cinco diferentes métodos adquiridos através da revisão bibliográfica e comparados aos dados adquiridos em campo, conforme segue:

- Painel Intergovernamental para Mudança Climática - IPCC (IPCC, 2006), o qual é convencionalmente utilizado na elaboração de inventários de gases de efeito estufa.

Na implementação do método proposto pelo IPCC (2006) adotaram-se os parâmetros apresentado na Tabela 9:

Tabela 9- Parâmetros utilizados para implementação do método proposto pelo IPCC (2006).

\begin{tabular}{ccc}
\hline Parâmetro & Símbolo & Valor utilizado \\
\hline Número de habitantes que encaminham esgoto & Pop & 421642 habitantes
\end{tabular}




\begin{tabular}{|c|c|c|}
\hline Parâmetro & Símbolo & Valor utilizado \\
\hline \multicolumn{3}{|l|}{ para a ETE } \\
\hline Taxa de contribuição per capta de DQO & $Q P C D Q O$ & dado operacional \\
\hline Capacidade máxima de produção de metano & $B O$ & $0,25 \mathrm{kgCH}_{4} / \mathrm{kgDQOremov}$ \\
\hline Fator de correção do metano & $M C F$ & 0,8 \\
\hline Fator de emissão de metano & $E F$ & $0,2 \mathrm{kgCH}_{4} / \mathrm{kgDQOremov}$ \\
\hline Coeficiente de produção de sólidos no sistema & $Y$ & $0,18 \mathrm{kgSTV} / \mathrm{kgDQOremov}$ \\
\hline $\begin{array}{l}\text { Fator de conversão de sólidos totais voláteis } \\
\qquad \text { em DQO }\end{array}$ & $\begin{array}{l}K S T V- \\
D Q O\end{array}$ & 1,42 kg DQOlodo/kgSTV \\
\hline $\begin{array}{l}\text { Eficiência de remoção de DQO do esgoto } \\
\text { obtida com o tratamento nos reatores }\end{array}$ & hremDQO & Dado operacional \\
\hline Recuperação de metano & $R$ & 0 (não há) \\
\hline $\begin{array}{c}\text { População responsável pela produção do } \\
\text { esgoto doméstico }\end{array}$ & $I$ & 1 (urbano) \\
\hline Componente orgânico removido como lodo & $S$ & Y x K KTV-DQO $\times \mathrm{h}_{\text {remDQO }}$ \\
\hline Percentual de população urbana & $U$ & 1 (urbana) \\
\hline Tipo de tratamento & $T$ & 1 (anaeróbio) \\
\hline
\end{tabular}

- Convenção-Quadro das Nações Unidas sobre a Mudança do Clima - UNFCCC (UNFCCC, 2013), que é tipicamente empregado em estudos sobre mecanismos de desenvolvimento limpo.

Por sua vez, no desenvolvimento do método sugerido pelo UNFCCC (2013) consideraram-se os parâmetros apresentados na Tabela 10.

Tabela 10 - Parâmetros utilizados para implementação do método proposto pelo UNFCCC (2013).

\begin{tabular}{ccc}
\hline Parâmetro & Símbolo & Valor utilizado \\
\hline Vazão de esgoto tratado pelos reatores UASB & Qesgoto & Dado operacional \\
DQO do esgoto afluente aos reatores & DQOafluente & Dado operacional \\
Eficiência de remoção de DQO do esgoto & & \\
obtida com o tratamento nos reatores & $h r e m D Q O$ & Dado operacional \\
Fator de correção do metano & $M C F$ & 0,8 \\
Capacidade máxima de produção de metano & $B O$ & $0,25 \mathrm{kgCH}_{4} / \mathrm{kgDQOremov}$ \\
Fator de correção de incertezas & $U F$ & 0,89 \\
\hline
\end{tabular}


- Chernicharo (1997), o qual pauta-se em um balanço de massa de DQO

Para estimar o potencial de produção de energia a partir do biogás de acordo com o método reportado por Chernicharo (1997), empregaram-se (Tabela 11).

Tabela 11 - Parâmetros utilizados para implementação do método proposto por Chernicharo (1997).

\begin{tabular}{ccc}
\hline Parâmetro & Símbolo & Valor utilizado \\
\hline Vazão de esgoto tratado pelos reatores UASB & Qesgoto & Dado operacional \\
DQO do esgoto afluente aos reatores & DQOafluente & Dado operacional \\
DQO filtrada do esgoto após o tratamento nos & DQOefluente & Dado operacional \\
reatores & $Y$ & $0,18 \mathrm{kgSTV} / \mathrm{kgDQOremov}$ \\
Coeficiente de produção de sólidos no sistema & & \\
Fator de conversão de sólidos totais voláteis & $K S T V-D Q O$ & $1,42 \mathrm{kgDQOlodo} / \mathrm{kgSTV}$ \\
em DQO & & \\
\hline
\end{tabular}

- Lobato (2011), cuja modelagem baseia-se no balanço de massa de DQO no reator UASB, considerando os percentuais de perdas intrínsecas ao processo.

Para implementar o modelo proposto por Lobato (2011), utilizaram-se (Tabela 12):

Tabela 12 - Parâmetros utilizados para implementação do método proposto por Lobato (2011)

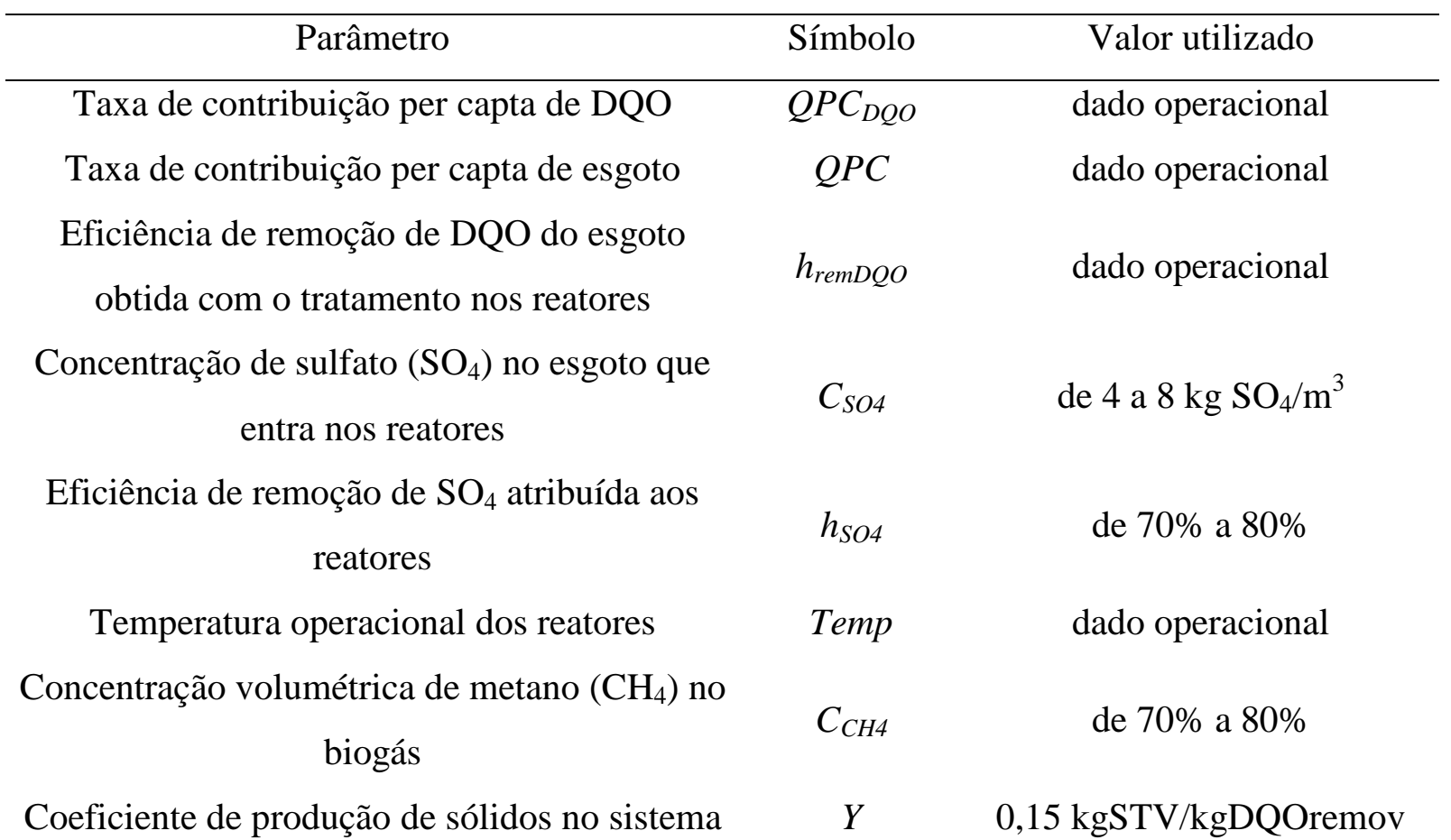

Fator de conversão de sólidos totais voláteis

$$
\text { em DQO }
$$$$
\text { KSTV-DQO } \quad 1,42 \mathrm{~kg} \text { DQOlodo/kgSTV }
$$

Fator de DQO consumida na redução do

$\mathrm{KDQO}-\mathrm{SO}_{4} \quad 0,667$ 


\begin{tabular}{|c|c|c|}
\hline Parâmetro & Símbolo & Valor utilizado \\
\hline sulfato & & $\mathrm{kgDQO} / \mathrm{kgSO}_{4}$ convertido \\
\hline $\begin{array}{l}\text { Percentual de perdas de metano na fase gasosa } \\
\text { com o gás residual }\end{array}$ & $p_{w}$ & $7,50 \%$ \\
\hline $\begin{array}{l}\text { Percentual de outras perdas de metano na fase } \\
\text { gasosa }\end{array}$ & $p_{O}$ & $7,50 \%$ \\
\hline $\begin{array}{c}\text { Coeficiente de perda referente ao metano } \\
\text { dissolvido no meio líquido }\end{array}$ & $p_{L}$ & $25 \mathrm{mg} / \mathrm{L}$ \\
\hline
\end{tabular}

- CETESB (2006), baseado na matéria total gerada pela população:

O modelo baseado na matéria total gerada pela população proposto pela CETESB (2006), foi adaptado para utilizar (Tabela 13):

Tabela 13 - Parâmetros utilizados para implementação do método proposto por CETESB (2006)

\begin{tabular}{ccc}
\hline Vazão de esgoto tratado pelos reatores UASB & $Q_{\text {esgoto }}$ & Dado operacional \\
$\begin{array}{c}\text { Concentração volumétrica de metano }\left(\mathrm{CH}_{4}\right) \text { no } \\
\text { biogás }\end{array}$ & $C_{C H 4}$ & $60 \%$ \\
$\begin{array}{c}\text { Produção de biogás } \\
\text { Matéria total enviada ao esgoto por habitante a } \\
\text { cada dia }\end{array}$ & $P_{b i}$ & $0,001 \mathrm{~kg}$ biogás $/ \mathrm{kg} \mathrm{Mt}$ \\
\hline
\end{tabular}

Os métodos supracitados foram adaptados de forma a propiciar a utilização da maior quantidade de informações operacionais relacionadas com a ETE sob análise, bem como para fornecer os resultados em unidade de vazão de biogás por hora $\left(\mathrm{Nm}^{3} / \mathrm{h}\right)$ e também em unidade de potência química disponível $(\mathrm{kW})$. Por isso, nos métodos propostos pelo IPCC (2006) e por Lobato (2011), calcularam-se Pop, $Q P C$ e/ou $Q P C_{D Q O}$ a partir do histórico de dados de vazão média de esgoto tratado nos reatores UASB $\left(Q_{\text {esgoto }}\right)$ e de DQO do esgoto afluente aos reatores $\left(D Q O_{\text {afluente }}\right)$, bem como para utilizar o método proposto pela CETESB (2006), os quais os valores de $P b_{i}, M t$ e $f \mathrm{DBO}_{5}$. Os desvios padrão das estimativas foram calculados e considerados como incertezas.

Os resultados das estimativas foram analisados estatisticamente e comparados com aqueles encontrados a partir de medições realizadas nos reatores da ETE em tempo real e em

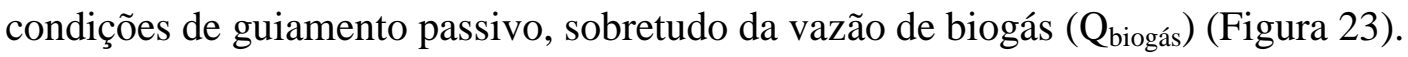




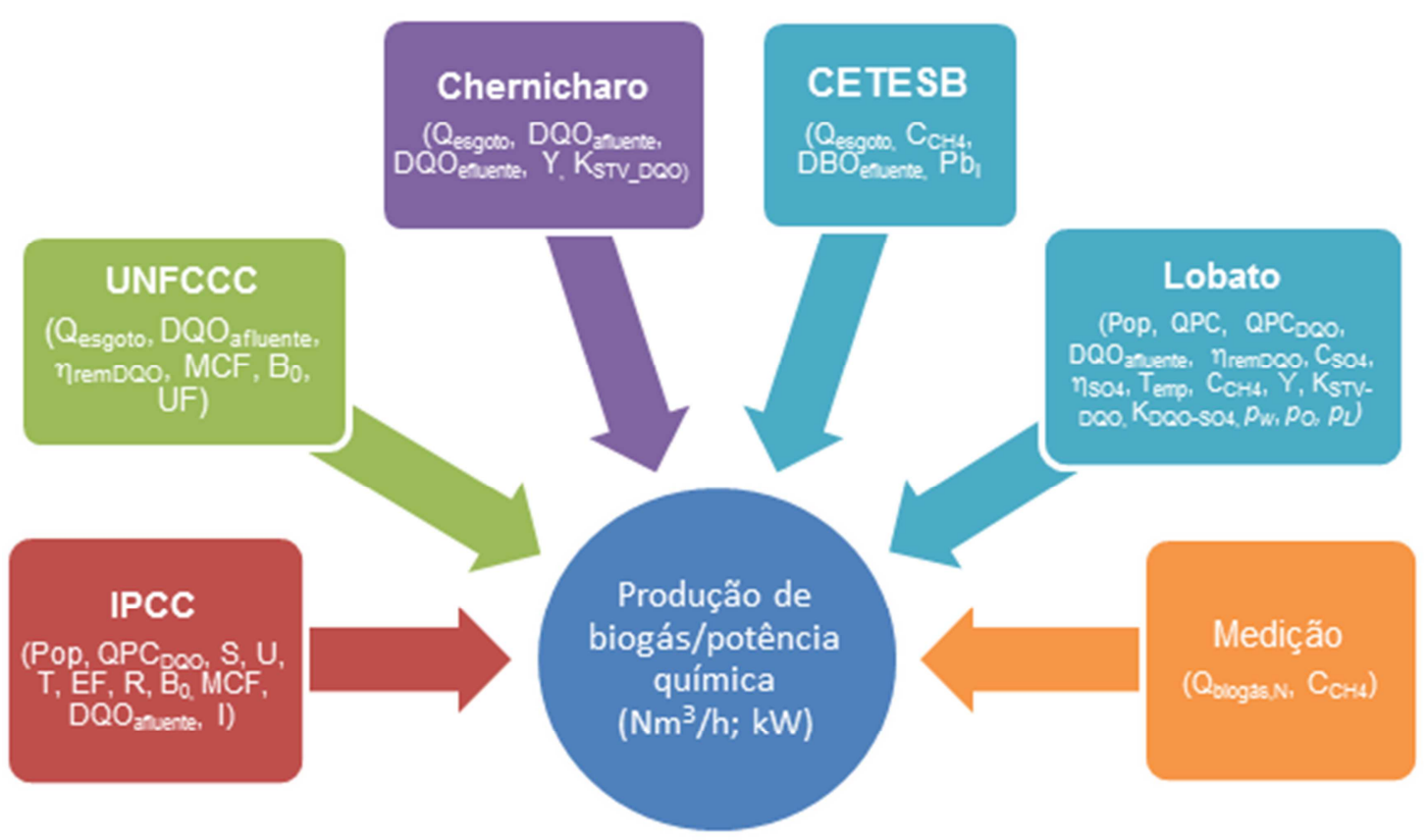

Figura 23 - Estimativa do potencial de produção de biogás por meio de métodos reportados na literatura e comparação com os resultados de medições realizadas em campo

Fonte: A Autora.

Para estimar o potencial de aproveitamento energético do biogás produzido foi considerado primeiro a potência bruta disponível. O poder calorífico do biogás depende da porcentagem de metano $\left(\mathrm{CH}_{4}\right)$ nele existente. $\mathrm{O}$ metano puro, em condições normais ${ }^{5}$, possui um poder calorífico de $9,9 \mathrm{kWh} / \mathrm{Nm}^{3}$, ao passo que o biogás com concentração de metano variando entre $50 \%$ e $80 \%$ tem um poder calorífico inferior de 4,95 a 7,9 kWh/ $\mathrm{Nm}^{3}$ (CCE, 2000).

Por fim, também foram quantificadas as relações unitárias de produção de metano, biogás e de energia nos reatores UASB tratando esgotos domésticos, e os resultados foram comparados àqueles encontrados por Lobato (2011).

6.5 Avaliação dos custos evitados ao aproveitar o biogás para geração de energia elétrica

${ }^{5} \mathrm{CNPT}$ (pressão a 1,0 atm e temperatura de $0^{\circ} \mathrm{C}$ ) 
Para a análise do perfil de uso de eletricidade, foram utilizadas as tarifas de energia elétrica e o histórico de consumo de energia elétrica da ETE Atuba Sul no período de análise.

Em seguida foram calculadas a potência química e potência elétrica disponibilizada com base na vazão de biogás disponível considerando o rendimento médio dos atuais equipamentos de conversão de energia, que gira em torno de $33 \%$ para os motores a gás e de ciclo Otto.

Os dados de autoprodução de energia da ETE foram comparados à energia consumida da rede elétrica no mesmo período e em seguida foram analisados três cenários:

- No primeiro foi considerado a autoprodução de energia na ETE Atuba Sul e não foi considerada a utilização da Resolução Normativa $n^{\circ} 482$ da ANEEL e, portanto, não contempla a injeção de possível excedente de energia na rede de distribuição;

- No segundo foi considerada a autoprodução de energia na ETE e possível injeção de energia elétrica excedente na rede de distribuição;

- No terceiro cenário, foi considerado a autoprodução de energia na ETE, com a possível injeção de energia elétrica excedente na rede de distribuição, mas que não haveria cobrança de impostos para a energia compensada.

O histórico de consumo de energia elétrica da ETE obtido engloba, além do consumo de energia, a demanda de potência ativa contratada, o excedente de reativos, fator de carga real, taxa de iluminação, encargos e outros produtos. No entanto, nos cálculos foi levado em consideração apenas o custo da energia elétrica evitado, visto que os outros componentes deverão continuar a ser cobrados normalmente.

6.6 Emissões de gases de efeito estufa evitadas a partir dos resultados medidos

Para o cálculo das emissões de gases de efeito estufa evitadas foram utilizados dois métodos: o primeiro teve como objetivo contabilizar quanto de emissão foi evitada por utilizar o biogás medido durante os estudos para aproveitamento energético ao invés liberá-lo na atmosfera. Considerou-se nessas avaliações apenas as emissões de metano, uma substância gasosa com elevado poder calorífico inferior $(50 \mathrm{MJ} / \mathrm{kg}$ ) e com potencial de aquecimento global atualmente avaliado como 25 vezes maior que o $\mathrm{CO}_{2}$ (IPCC, 2007c). 
Em seguida foram contabilizados quanto de emissão foi evitada no Sistema Interligado Nacional (SIN) de energia no Brasil, e para isso foram utilizados os fatores de emissão por geração de eletricidade (Tabela 14) para os meses de análise.

Tabela 14 - Fatores de emissão por geração de eletricidade no Sistema Interligado Nacional (SIN)

\begin{tabular}{cc}
\hline Mês & $\mathrm{tCO}_{2} / \mathrm{MWh}$ \\
\hline Out-2011 & 0,035 \\
Nov-2011 & 0,0356 \\
Dez-2011 & 0,0349 \\
Jan-2012 & 0,115 \\
Fev-2012 & 0,109 \\
Mar-2012 & 0,098 \\
Abr-2012 & 0,096 \\
Mai-2012 & 0,115 \\
Jun-2012 & 0,108 \\
Jul-2012 & 0,084 \\
Ago-2012 & 0,083 \\
Set-2012 & 0,084 \\
Out-2012 & 0,083 \\
\hline
\end{tabular}

Fonte: Adaptado de MINISTÉRIO DA CIÊNCIA E TECNOLOGIA (2013)

Por fim, foi realizado um comparativo com os fatores de emissão mais recentes e calculados os possíveis certificados de emissões evitadas de carbono que este projeto poderia gerar. 


\section{RESULTADOS E DISCUSSÕES}

7.1 Análise dos parâmetros físico e químicos do esgoto da ETE Atuba Sul.

Durante o período de avaliação, a vazão média do esgoto doméstico que entrou nos reatores UASB da ETE Atuba Sul (Qesgoto) foi de $(988,08 \pm 85,2)$ L/s, com mínimo de 768 e máximo de 1.174 L/s (Figura 24).

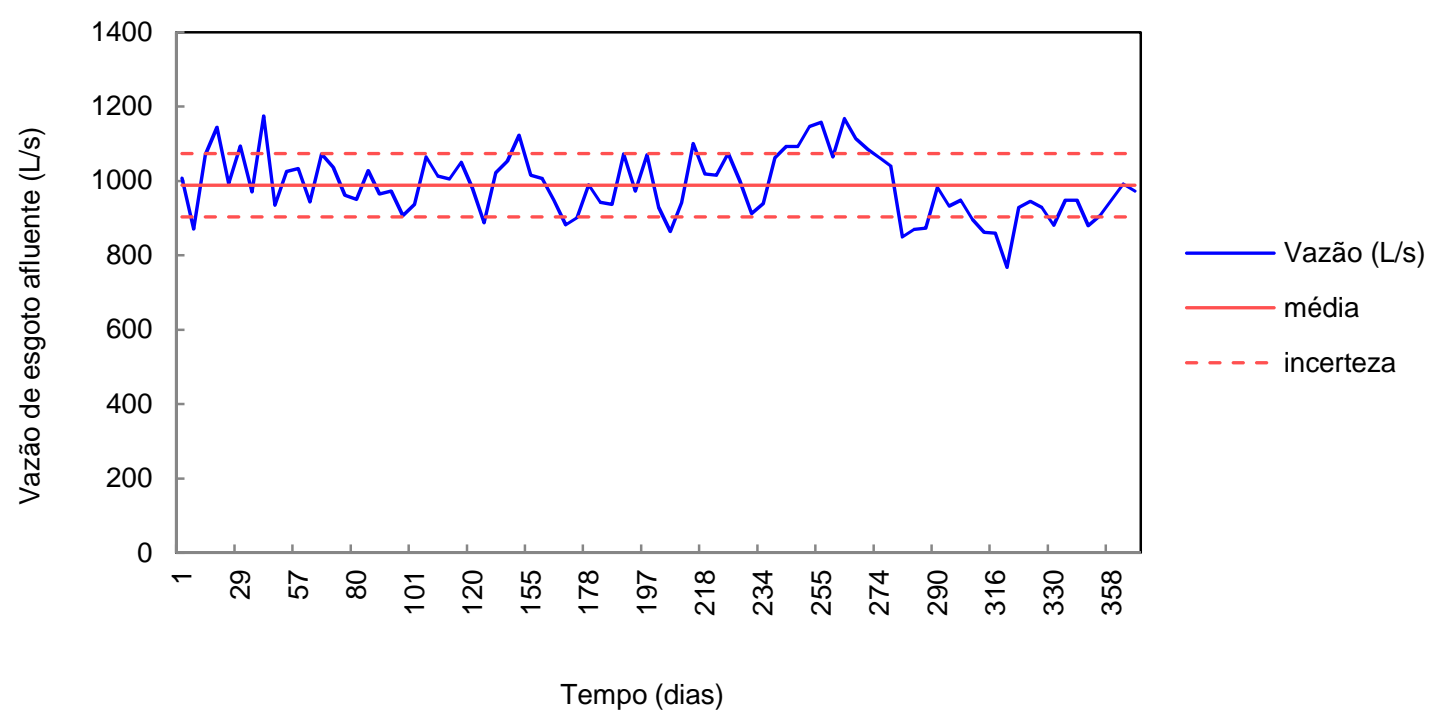

Figura 24 - Vazão de esgoto que entrou pelos reatores UASB ao longo do tempo

Dessa maneira, considerando a contribuição per capita de $\mathrm{DQO}\left(\mathrm{QPC}_{\mathrm{DQO}}\right)$ igual a 90 gDQO/hab.dia (VON SPERLING e CHERNICHARO, 2005), tem-se que a população média equivalente atendida pela (Pop) foi de (421.642 \pm 126.461$)$ habitantes.

Os valores médios de temperatura, DQO, DBO, sólidos sedimentáveis do esgoto afluente e efluente dos reatores UASB são apresentados na Tabela 15. Esses resultados sugerem que o efluente possui características típicas de esgotos domésticos de concentração média de carga orgânica.

Tabela 15 - Dados médios do afluente e do efluente dos reatores UASB.

\begin{tabular}{lccccc}
\hline & $\begin{array}{c}\text { Temperatura } \\
\left({ }^{\circ} \mathrm{C}\right)\end{array}$ & $\begin{array}{c}\text { DQO filtrada } \\
(\mathrm{mg} / \mathrm{L})\end{array}$ & $\begin{array}{c}\mathrm{DBO} \\
(\mathrm{mg} / \mathrm{L})\end{array}$ & $\begin{array}{c}\text { Sólidos } \\
\text { sedimentáveis } \\
(\mathrm{mg} / \mathrm{L})\end{array}$ & $\begin{array}{c}\text { Sólidos } \\
\text { suspensos } \\
(\mathrm{mg} / \mathrm{L})\end{array}$ \\
\hline Afluente & $20,0 \pm 2,0$ & $449,7 \pm 143,2$ & $230,6 \pm 72,9$ & $4,1 \pm 1,8$ & $175,0 \pm 62,6$ \\
Efluente & $19,9 \pm 2,0$ & $114,2 \pm 29,46$ & $84,8 \pm 29,2$ & $1,5 \pm 0,78$ & $107,1 \pm 42,23$ \\
\hline
\end{tabular}


A DQO média desse esgoto (DQOafluente) foi de $(449,7 \pm 143,2) \mathrm{mg} / \mathrm{L}$, variando de 138 a $905 \mathrm{mg} / \mathrm{L}$ e a DQO média filtrada após os reatores UASB (DQOefluente) foi de (114,22 $\pm 29,46) \mathrm{mg} / \mathrm{L}$, variando de 35,0 a 207,0 mg/L. A DQO de saída, apesar de ser variável, apresentou uma amplitude menor (358 mg/L DQO) que a de entrada (767 mg/L DQO), indicando variação na eficiência de tratamento. Isso pode ocorrer devido ao tempo de residência do efluente no reator e à estabilidade do reator, ao passo que a DQO que entrou na ETE sofreu variação horária. A eficiência média de remoção de DQO do esgoto nos reatores UASB (hremDQO) foi de $(73 \pm 8) \%$ (Figura 25).

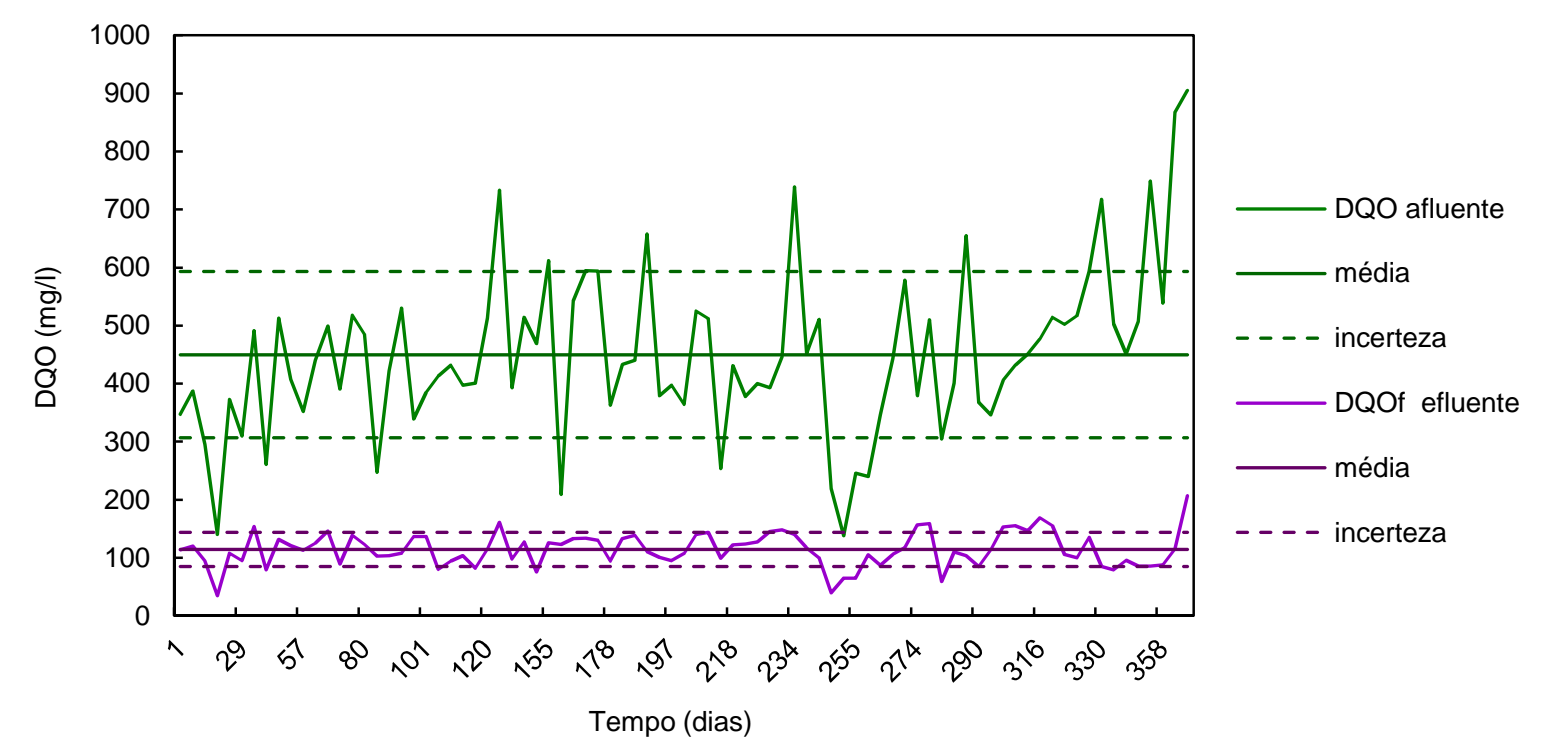

Figura 25 - DQO recebida pelos reatores UASB ao longo do tempo.

Fonte: A Autora.

Comparando os parâmetros do afluente que entrou na estação com o efluente que sai dos reatores anaeróbio, percebe-se que a variação de carga orgânica que entrou na ETE repetiu o mesmo padrão da DQO. A carga orgânica média desse esgoto foi de (37.948 \pm 11.993) kg/dia, variando de 13.663 a $76.081 \mathrm{~kg} /$ dia e a carga orgânica média filtrada após os reatores UASB foi de $(9.657 \pm 2.695) \mathrm{kg} / \mathrm{dia}$, variando de 3.459 a $18.130 \mathrm{~kg} / \mathrm{dia}$. A carga orgânica removida foi de $(28.290 \pm 11.025) \mathrm{kgDQO} /$ dia no período. A carga orgânica que entrou e saiu dos reatores ao longo do tempo está apresentada na (Figura 26). 


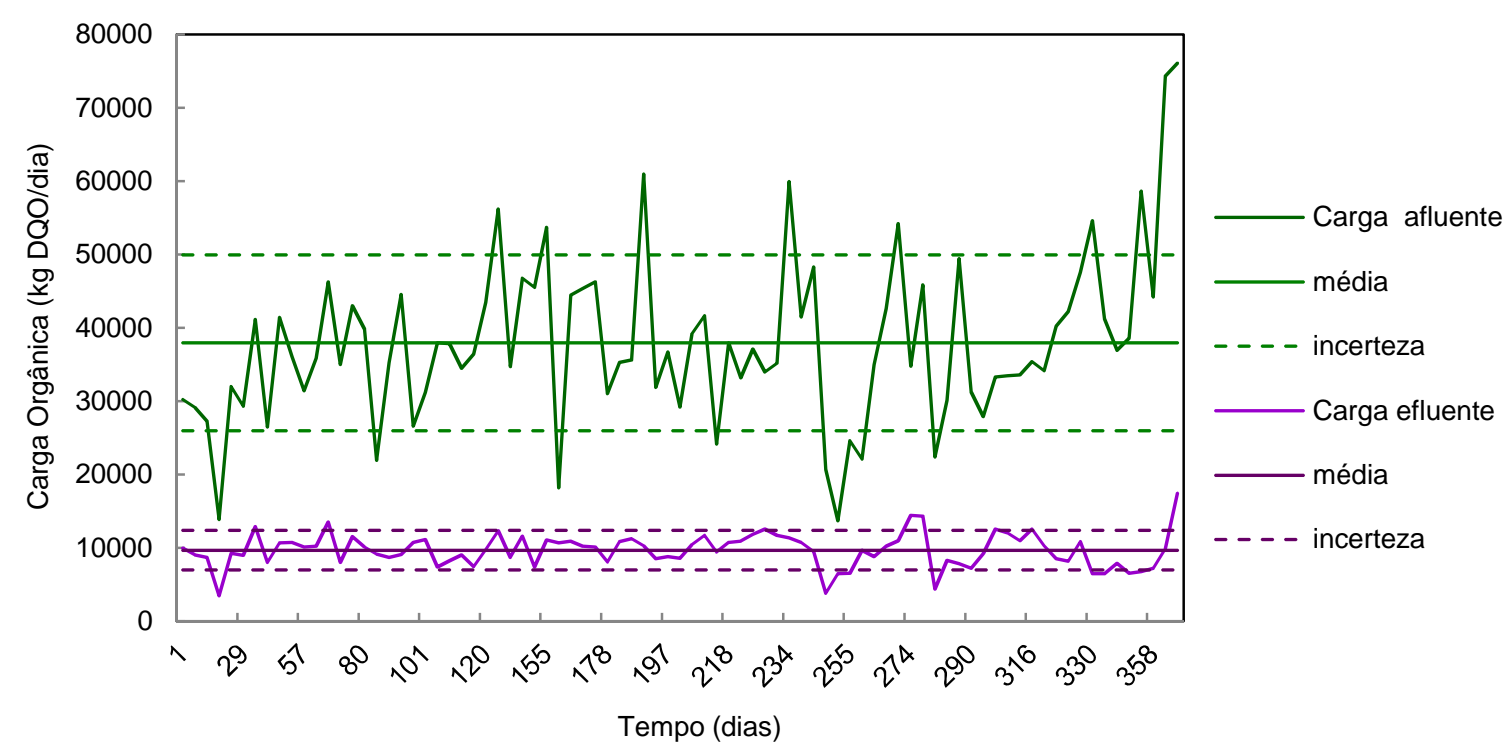

Figura 26- Carga orgânica que entrou e saiu pelos reatores UASB ao longo do tempo.

Fonte: A Autora.

Comportamento semelhante ocorre com a DBO do esgoto, conforme ilustra a (Figura 27). A DBO afluente média foi de $(230,6 \pm 72,9) \mathrm{mg} / \mathrm{L}$ e sua variação foi de 50 a $440 \mathrm{mg} / \mathrm{L}$. A DBO do efluente foi em média $(84,8 \pm 29,2) \mathrm{mg} / \mathrm{L}$ e variou entre 2 e $164 \mathrm{mg} / \mathrm{L}$, com desvio padrão de 29,2 mg/L. Portanto, a variação do efluente do reator é menor, o que também indica variação na eficiência de tratamento, pelos mesmos motivos já apontados. A eficiência média de remoção de DBO do esgoto nos reatores UASB $\left(\mathrm{h}_{\text {rem }} \mathrm{DBO}\right)$ foi de $(61,0 \pm 11,0) \%$.

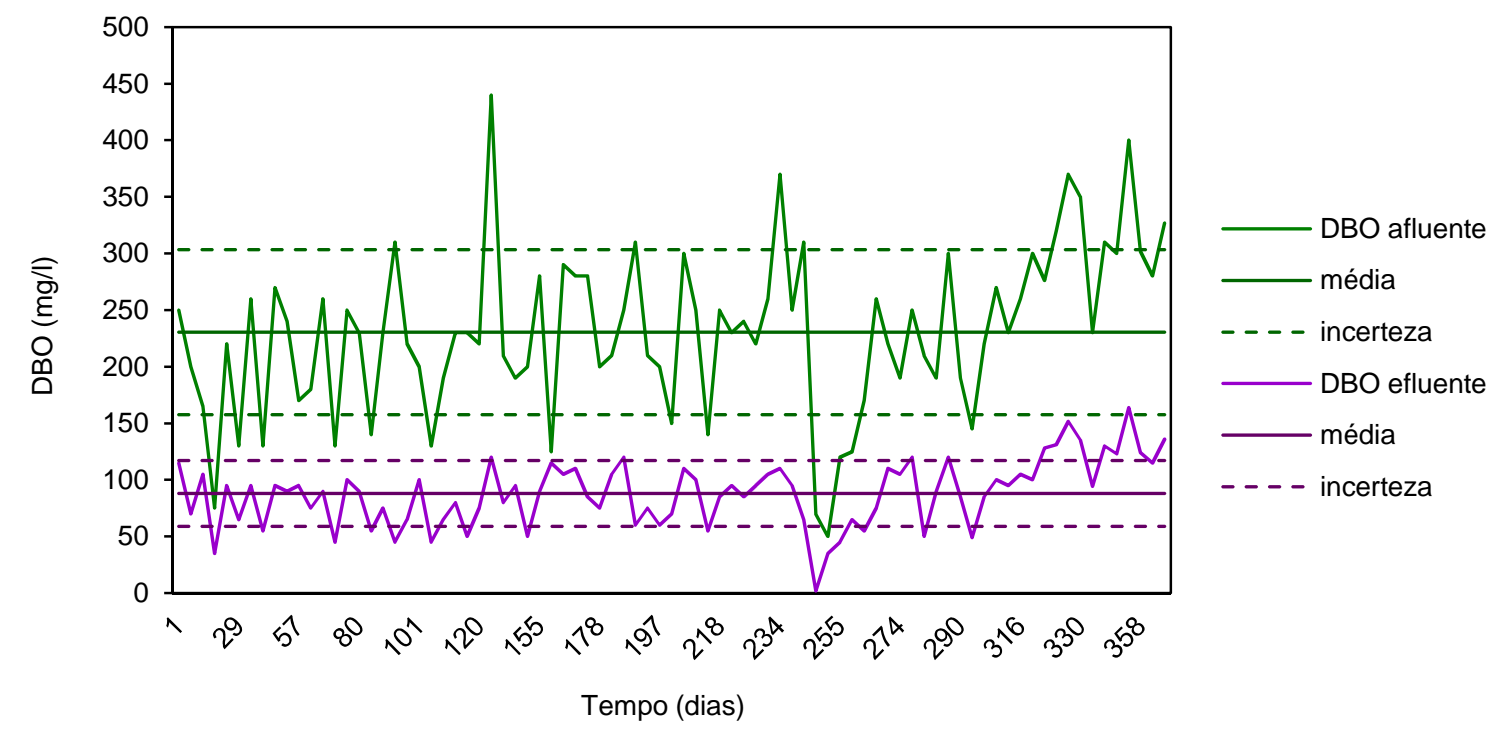

Figura 27 - DBO afluente e efluente ao longo do tempo.

Fonte: A Autora. 
O comportamento da eficiência de tratamento, por sua vez, seguiu a tendência de ser maior para a DQO que a DBO. A eficiência média de remoção de DQO foi de $(73 \pm 8) \%$ e de DBO $(61 \pm 11) \%$. Segundo Von Sperling (1995), a faixa típica de eficiência de remoção de DBO para reatores anaeróbios é de 60-80\%, indicando que a eficiência de DBO está dentro da faixa esperada (Figura 28).

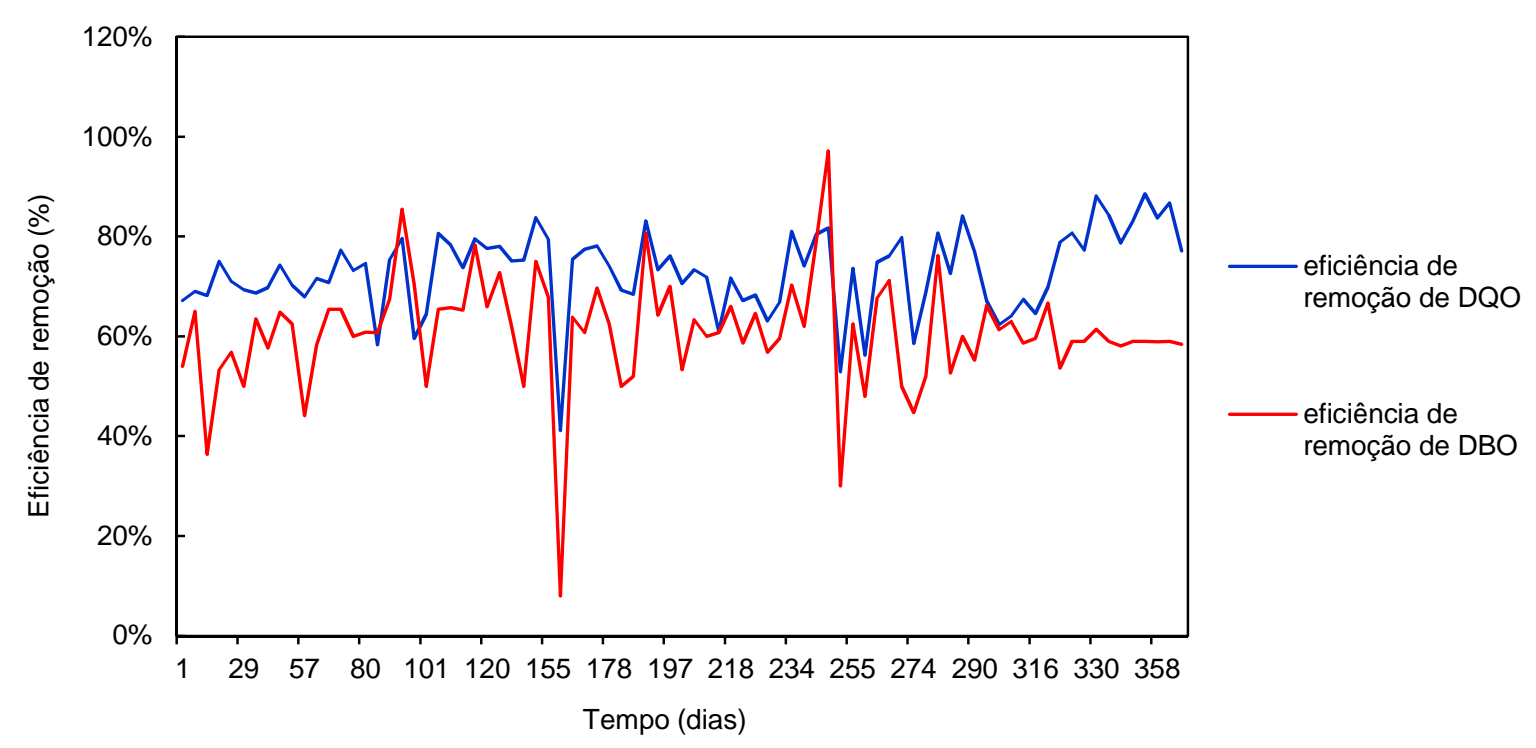

Figura 28 - Eficiência de remoção dos reatores UASB ao longo do tempo

A razão DQO/DBO do esgoto também foi analisada. Segundo Von Sperling (1995), esta relação varia em torno de 1,7 a 2,4. Para a ETE Atuba Sul o valor médio foi de 2,0 com máxima de 3,2 e mínima de 1,4.

Considerando que há grande variação de vazão, carga orgânica recebida pela ETE e também na eficiência de tratamento, pode-se esperar variação também na produção de biogás da ETE, visto que o biogás é função da quantidade de matéria orgânica degradada pelos reatores.

7.2 Quantificação em tempo real das taxas de produção de biogás e de metano na ETE Atuba Sul

A vazão de biogás disponibilizada pelo sistema de coleta da ETE ao longo do período de estudo foi, em média, igual a $(84,30 \pm 26,64) \mathrm{Nm}^{3} / \mathrm{h}$. O teor de metano presente no biogás 
foi, em média, $(63,03 \pm 17,89) \%$ v/v, resultando em uma vazão média de metano de $(53,13 \pm$ $15,04) \mathrm{Nm}^{3} / \mathrm{h}$.

As vazões médias mensais são apresentadas na Figura 29, na qual se percebe que houve tendência de redução de vazão nos meses de abril e maio. Em maio ocorreu a menor vazão média de biogás $(47,59 \pm 27,3) \mathrm{Nm}^{3} / \mathrm{h}$, mantendo-se abaixo da média de todo o período de análise até julho de 2012. Em março de 2012 ocorreu um aumento significativo da vazão atingindo um valor médio de $(113,25 \pm 13,51) \mathrm{Nm}^{3} / \mathrm{h}$.

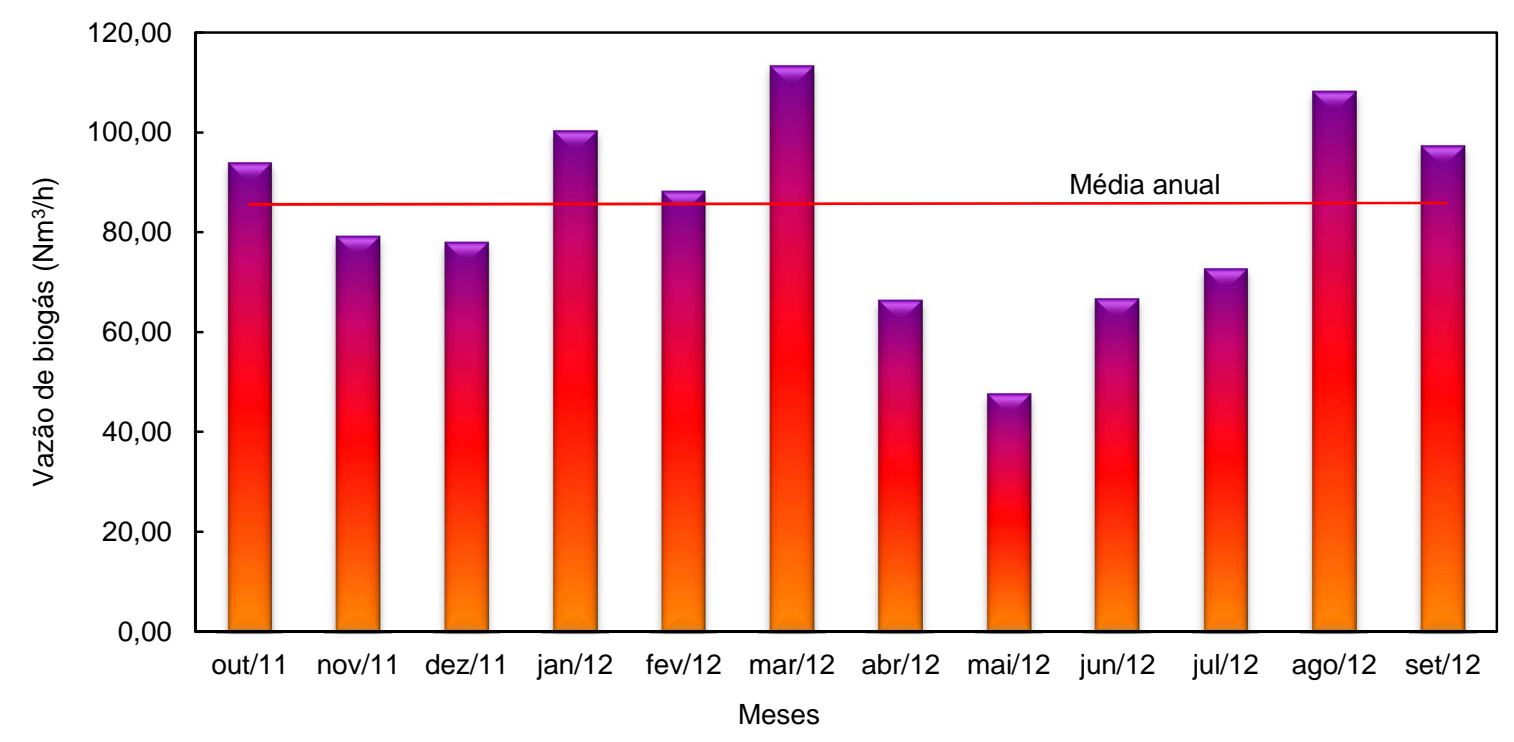

Figura 29 - Vazão média de biogás mensal em função do tempo para um intervalo de ano.

Fonte: A Autora.

Analisando os dados diariamente (Figura 30), percebe-se uma distribuição variável das médias de vazão de biogás, onde pode-se ainda detectar que as vazões máximas e mínimas foram bem características, sendo a máxima $136,52 \mathrm{Nm}^{3} / \mathrm{h}$ e a mínima igual a $28,17 \mathrm{Nm}^{3} / \mathrm{h}$. Também foi possível detectar, uma diminuição acentuada na vazão de biogás que se iniciou em 18 de março de 2012 e que durou até 26 de maio de 2012, coincidindo com o mês de menor vazão média. 


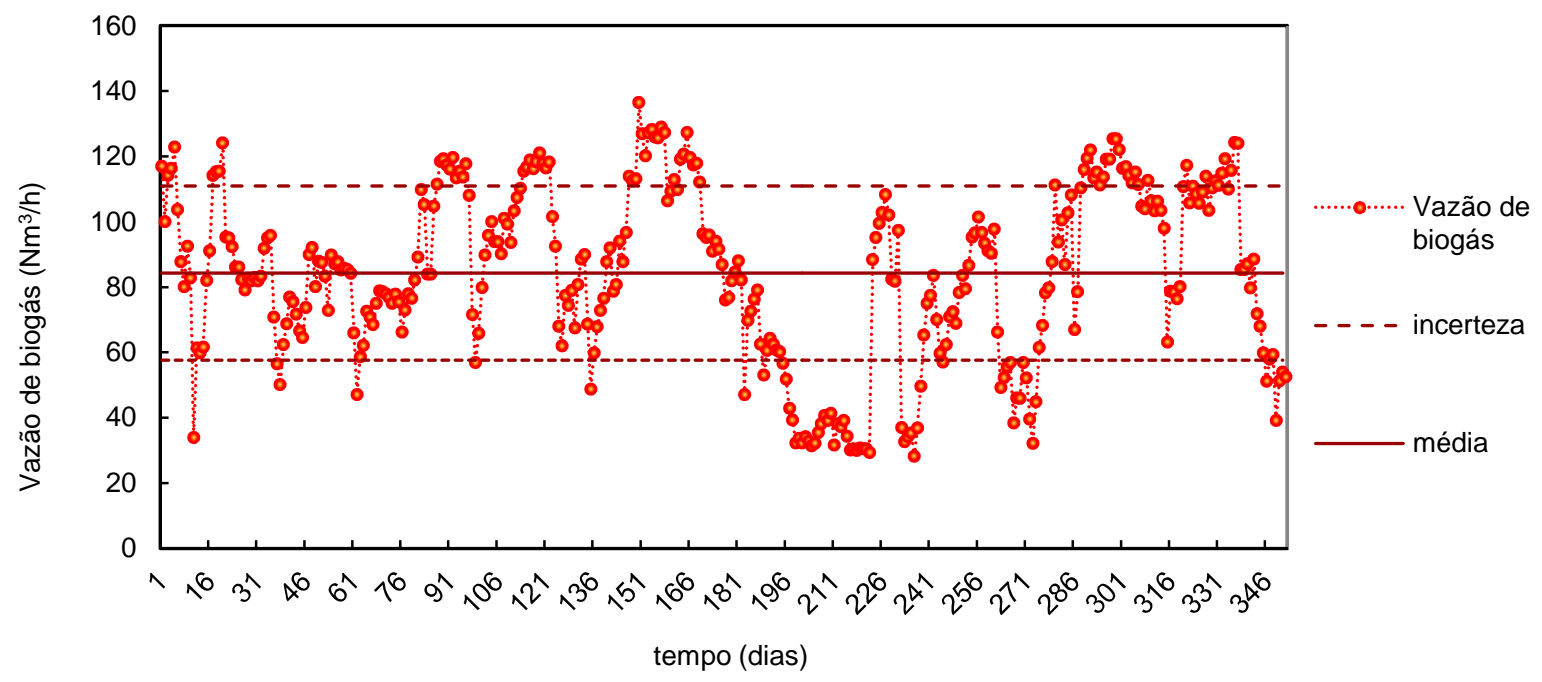

Figura 30 - Vazão média diária de biogás ao longo de um ano.

Fonte: A Autora.

Em seguida os dados foram analisados a cada 30 segundos, conforme adquiridos pelo equipamento. Nesta avaliação a vazão de biogás apresentou um comportamento temporal variável, periódico e não estacionário, corroborando o relatado por Possetti et al (2013). A frequência de produção e desprendimento de biogás foi diária $(\Delta \mathrm{t}=1$ dia). Ressaltasse que as vazões máximas ocorreram tipicamente entre 0 e 2 horas e as vazões mínimas entre 12 e 14 horas. A Figura 31 exemplifica esse comportamento para um intervalo de 10 dias. Além disso, percebeu-se que em alguns dias houve uma diminuição acentuada na vazão de biogás de $26,1 \%$, o que levou a análise dos fatores que podem levar a isso. 


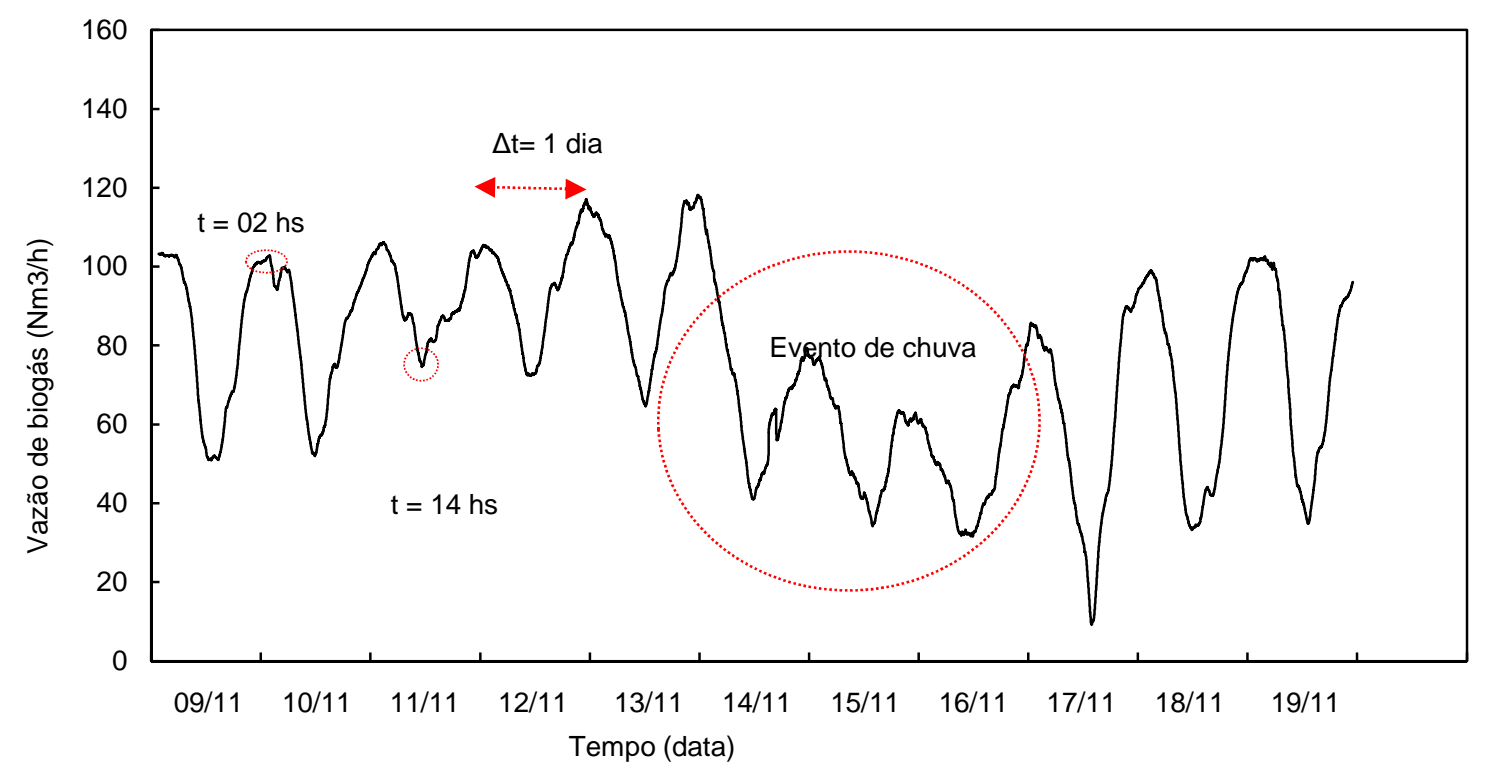

Figura 31 - Curva de vazão de biogás para um intervalo de 10 dias

Fonte: A Autora.

Também foi identificado que no período analisado a acentuada diminuição de vazão de biogás se deu em um dia de chuva, como pode ser visualizado na Tabela 16, que apresenta a pluviosidade do período de 09/11/2011 a 19/11/2011.

Tabela 16 - Pluviosidade diária no período de 09/11 a 19/11/2011.

\begin{tabular}{llllllllllll}
\hline DATA & $9 / 11$ & $10 / 11$ & $11 / 11$ & $12 / 11$ & $13 / 11$ & $14 / 11$ & $15 / 11$ & $16 / 11$ & $17 / 11$ & $18 / 11$ & $19 / 11$ \\
\hline$(\mathrm{mm})$ & 0 & 0 & 4 & 1,9 & 0 & 24,3 & 11,7 & 11,7 & 0,3 & 0 & 0 \\
\hline
\end{tabular}

Nos dias 11/novembro e 12/dezembro houve chuva fraca e não houve alterações significativas na vazão de biogás. No entanto, no dia 14/novembro houve chuva de moderada a forte que se estendeu até o dia 16/novembro como chuva moderada Nesse período houve uma significativa redução na vazão de biogás (em destaque na Figura 31).

Mediante estes resultados, as medições foram importantes para mostrar as flutuações inerentes à produção de biogás, de modo que, em caso de recuperação e aproveitamento do biogás serão esperadas flutuações na capacidade de geração de energia da planta. Essas características precisam ser consideradas no dimensionamento de plantas, em especial do gasômetro. 
7.3 Avaliação da influência dos efeitos dos eventos de chuva na produção de biogás

No período analisado, a precipitação acumulada na bacia de captação da ETE Atuba Sul foi de 1134,5 mm. A distribuição das chuvas acumuladas mensais foi em média de 93,48 mm e oscilou entre $24 \mathrm{~mm}$ e $198 \mathrm{~mm}$, o menor valor ocorreu no mês de maio de 2012 e o maior valor no mês de fevereiro de 2012 (Figura 32).

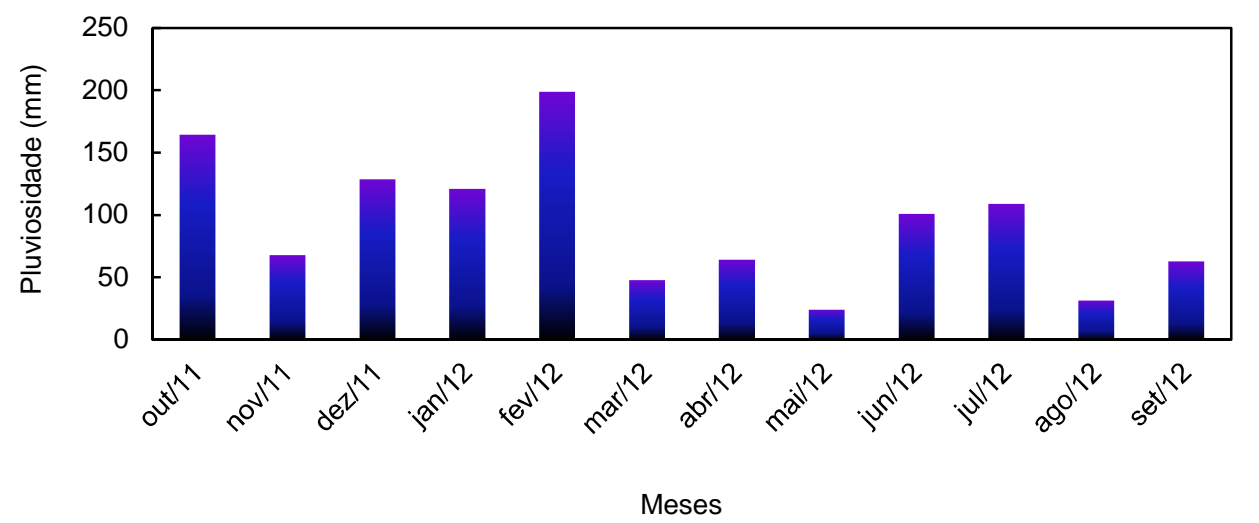

Figura 32 - Volume total de chuvas na bacia de captação da ETE Atuba Sul, no período analisado.

Fonte: A Autora.

O maior número de dias de chuvas ocorreu no mês de fevereiro com 15 dias de chuva, e coincidindo com o mês de maior precipitação acumulada. Já o mês com menos dias de chuva foi agosto de 2012, com 2 dias de chuva. Ao todo foram observados 102 dias chuvosos (Figura 33).

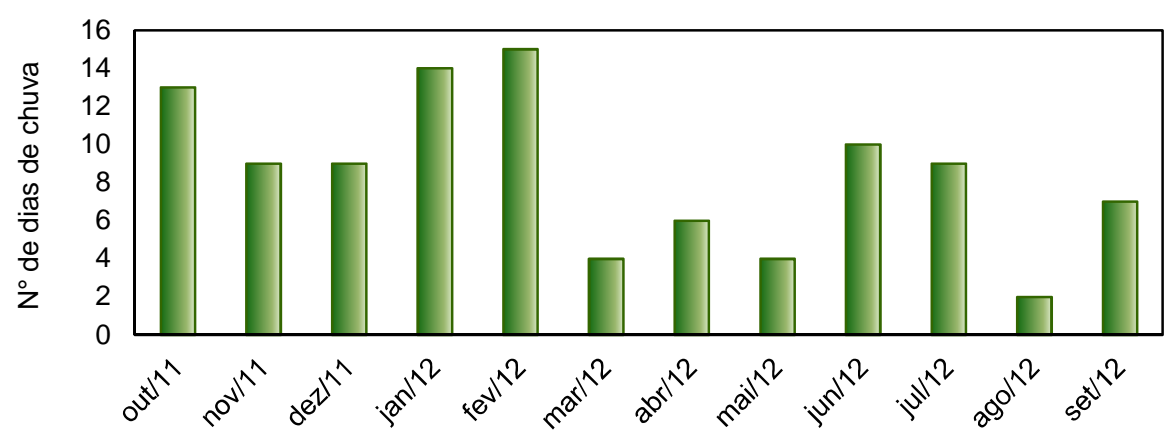

Meses

Figura 33 - Número de dias de chuva por mês na bacia de captação da ETE Atuba Sul, no período analisado.

Fonte: A Autora. 
Os eventos de chuvas foram então classificados conforme a proposta de Bustamante (2010), separando também os eventos de ausência de chuva, como pode ser visto na Figura 34.

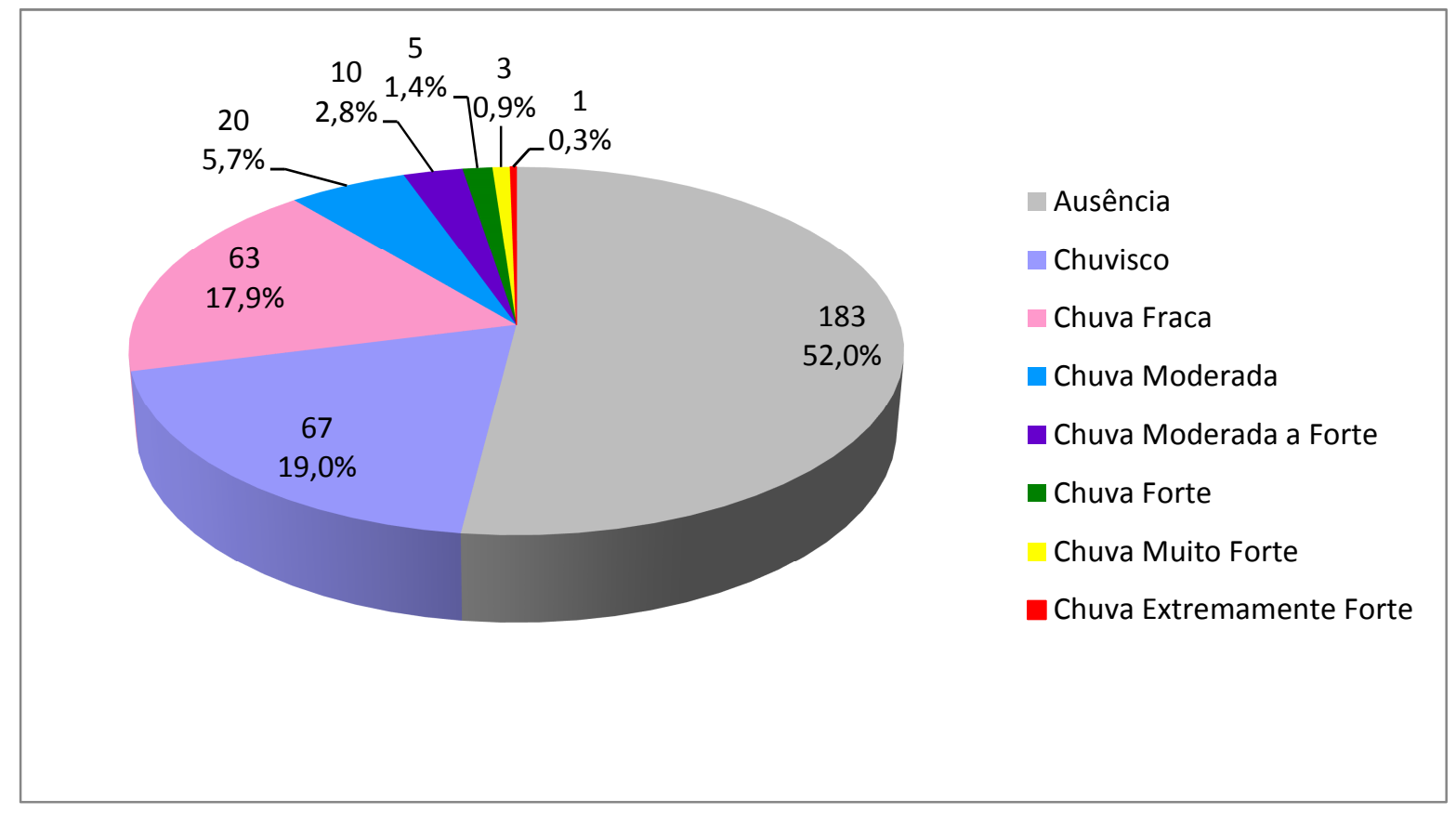

Figura 34 - Classificação e ocorrência das chuvas no período de análise.

Fonte: A Autora.

O evento ausência de chuva foi predominante e ocorreu em 52\% do período analisado, seguido pelos eventos chuvisco e chuva fraca, que representaram 19,0\% e 17,9\%, respectivamente. $\mathrm{O}$ evento chuva moderada representou 5,7\%, seguido pelo evento chuva moderada a forte $2,8 \%$, chuva forte, $1,4 \%$. Os eventos chuva muito forte e chuva extremamente forte representaram apenas $0,9 \%$ e $0,3 \%$, respectivamente. Mostrando uma tendência de que a intensidade da chuva é inversamente proporcional à probabilidade de sua ocorrência.

A Figura 35 apresenta as médias de chuvas mensais ao longo do período analisado, alinhadas aos dados de médias de vazão no mesmo período. De modo geral, há uma tendência de redução na vazão de biogás sempre que há precipitação mais intensa de chuva. 


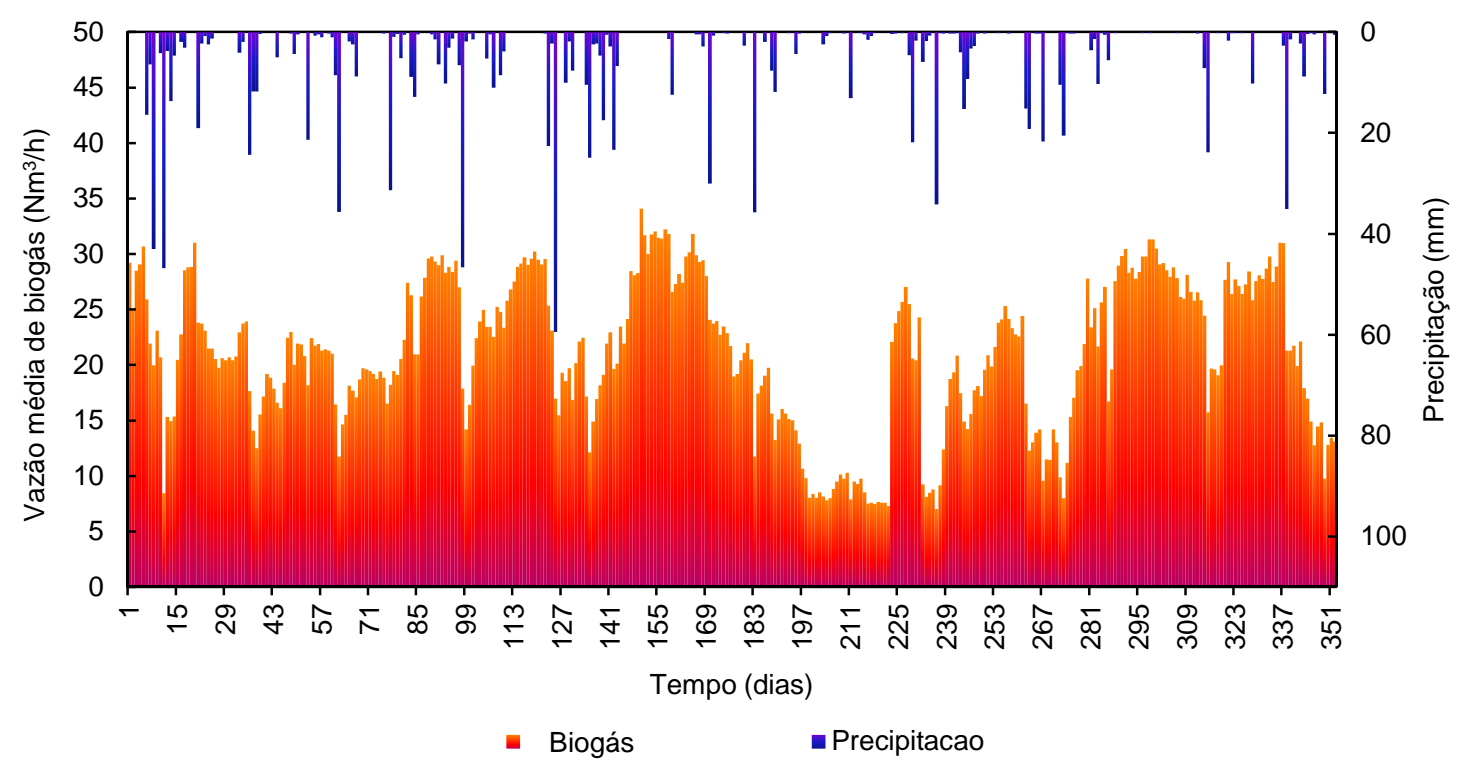

Figura 35 - Precipitação de chuva x vazão média de biogás.

Fonte: A Autora.

Na Figura 36, por sua vez, é apresentada a vazão média de biogás em função do índice de precipitação de chuva. Observa-se uma tendência de redução da vazão de biogás à medida que aumenta a precipitação de chuva. No entanto, em ausência de chuva, a variação se mostrou bastante grande, com mínima de 28,17 mm e máxima de 136,52 $\mathrm{mm}$, indicando que há outros fatores que podem influenciar a vazão de biogás ao longo do tempo.

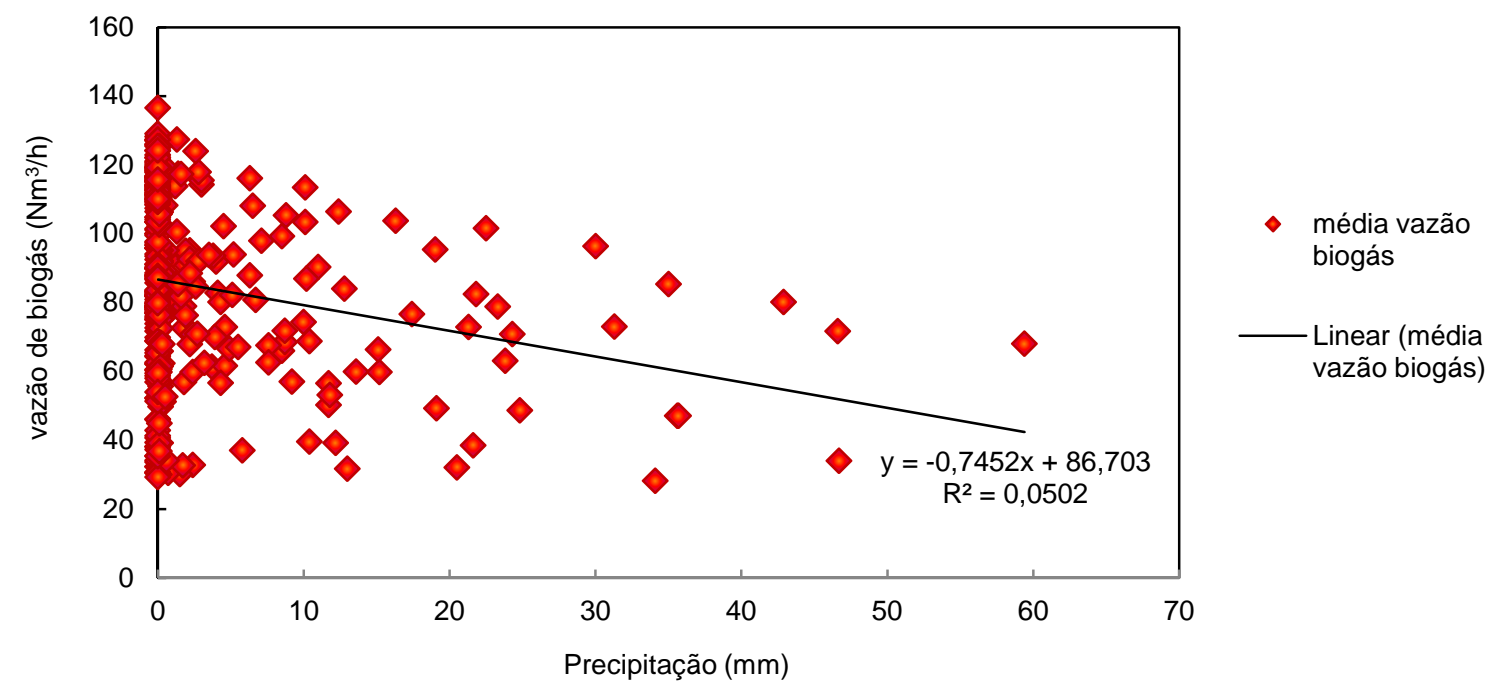

Figura 36 - Precipitação de chuva (mm) em função da vazão média de biogás $\left(\mathrm{Nm}^{3} / \mathrm{h}\right)$.

Fonte: A Autora. 
Para apurar os resultados, foi realizada a análise da variação de vazão média de biogás de um dia comparada à vazão de biogás do dia anterior, e distribuído em função da precipitação. Na Figura 37, os dados no eixo x negativo representam os dias em que houve redução de vazão de biogás em relação ao dia anterior, e no eixo x positivo os dias que houve aumento de vazão de biogás em relação ao dia anterior. O eixo y indica a quantidade de precipitação (mm). Em eventos de ausência de chuva e chuvisco percebe-se que há uma aglomeração dos pontos no eixo positivo e conforme aumenta a precipitação estes pontos tendem a se aglomerar no eixo negativo. Portanto, é possível perceber uma tendência maior de redução de vazão de biogás à medida que há aumento na quantidade de precipitação chuva.

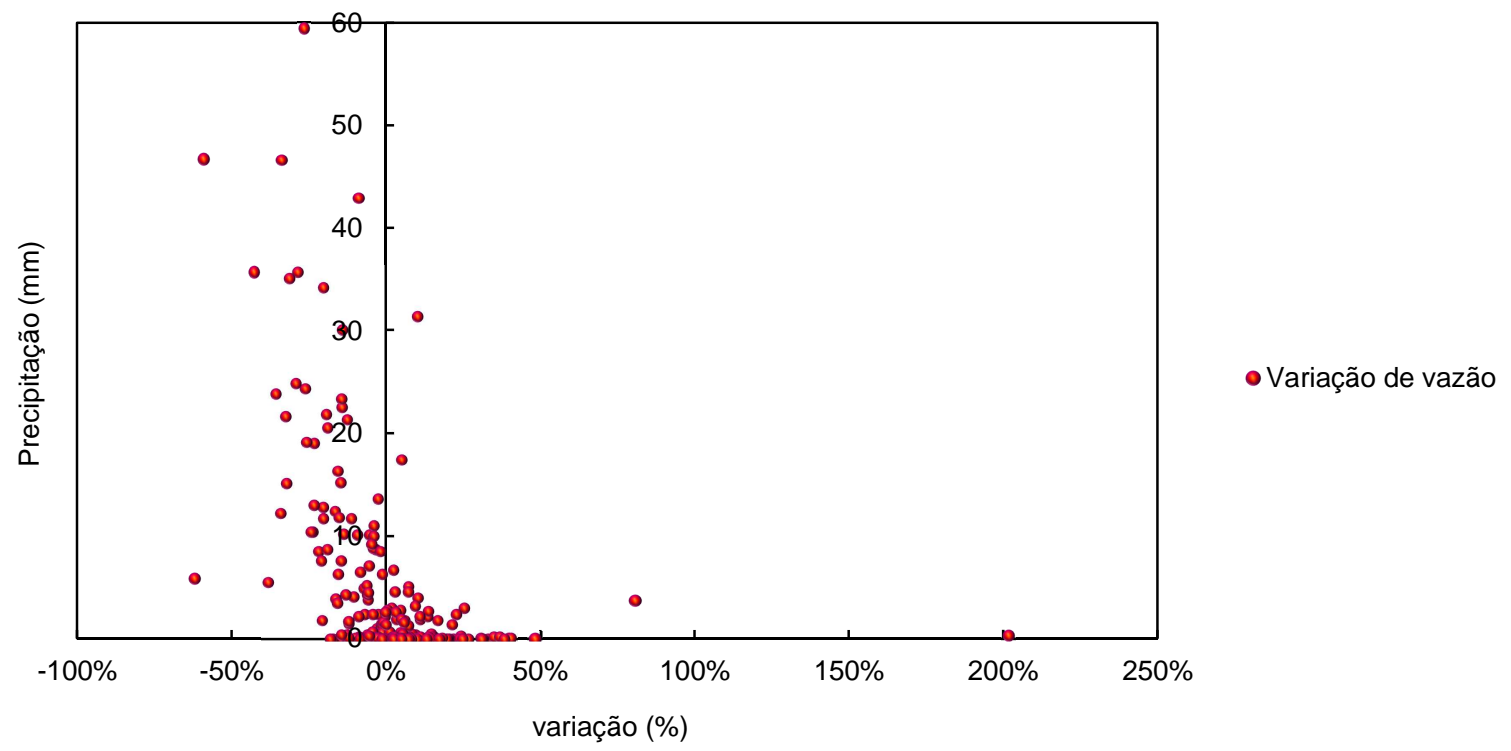

Figura 37 - Variação da vazão média de biogás de um dia em relação ao dia anterior em função da precipitação do dia analisado.

Fonte: A Autora.

Na ausência de chuva, houve reduções e aumentos de vazões aleatórios, que variaram de reduções de até $17,9 \%$ e aumento de vazão de até $202 \%$. Esse aumento de vazão significativamente maior se deu após um período de vários dias de redução de vazão consecutivos, o que pode indicar algum problema operacional na ETE que foi resolvido e causou este aumento de vazão fora da média.

Em eventos de chuva inferiores a $10 \mathrm{~mm}$, é possível notar uma distribuição aleatória da variação de vazão, indicando que nesses casos, a vazão pode reduzir ou aumentar em relação ao dia anterior e que a precipitação influiu pouco nesta variação. Por outro lado, nos eventos de chuva representados por precipitações acima de $10 \mathrm{~mm}$ apenas em dois eventos, de 
um total de 39, foi possível verificar o aumento da vazão de biogás, o equivalente à apenas $5 \%$ dos casos. Nos outros 37 eventos de chuva houve redução de vazão de biogás com relação ao dia anterior e essa variação foi em média de $20 \%$.

Ao analisar esses mesmo dados excluindo os eventos de ausência de chuva e separando os dados conforme proposto por Bustamante (2010) é possível identificar que no período houve apenas um evento de chuva extremamente forte $(>50 \mathrm{~mm})$. Nesse dia, a produção de biogás em relação ao dia anterior foi $26,5 \%$ menor.

Houve três eventos de chuvas muito forte (40 até $50 \mathrm{~mm}$ ). Durante esses eventos, a vazão média de biogás em relação ao dia anterior diminuiu, em média 33,8\%. Houve ainda cinco eventos de chuvas fortes (30 a $40 \mathrm{~mm}$ ), com redução de vazão de biogás média de 24,5\%. Em apenas um desses eventos não houve redução de vazão de biogás em relação ao dia anterior. Analisando esse evento pontualmente, percebe-se que no dia anterior ao evento de chuva, apesar de ser um período de ausência de chuva, houve redução na vazão de biogás.

No caso de chuvas moderadas a forte $(20$ a $30 \mathrm{~mm})$ houve 10 eventos. Em todos eles ocorreu a redução média da vazão de biogás com relação ao dia anterior, em média de 21,6\%, o que demonstra a interferência desses eventos na produção de biogás.

No caso de chuvas moderadas (10 a $20 \mathrm{~mm}$ ) houve 20 eventos e em apenas um desses eventos não houve redução de vazão de biogás quando comparado ao dia anterior. A redução média foi de $17 \%$, o que também demonstra que a chuva não é a única responsável por reduzir as vazões de biogás.

No caso de chuvas fracas (1 a $10 \mathrm{~mm}$ ) foram 63 ocorrências, sendo que 39 (62\%) apresentaram redução de vazão de biogás em relação ao dia anterior. Subdividindo essa classificação em chuvas menores ou iguais que $5 \mathrm{~mm}$ e maiores que $5 \mathrm{~mm}$, então há 18 eventos de chuva com precipitação acima de $5 \mathrm{~mm}$, dos quais apenas 2 não apresentam redução de vazão de biogás em relação ao dia anterior.

No caso de chuviscos (menor que $1 \mathrm{~mm}$ e maior que 0) também foram 67 eventos. Em apenas 25 desses eventos houve redução de biogás em relação ao dia anterior, indicando que a influência da chuva nesses casos é muito baixa, ou inexistente.

Essas informações estão representadas na Figura 38, na qual o eixo y aponta o volume de chuva do dia analisado e o eixo x aponta a variação de vazão de biogás em relação ao dia anterior. 


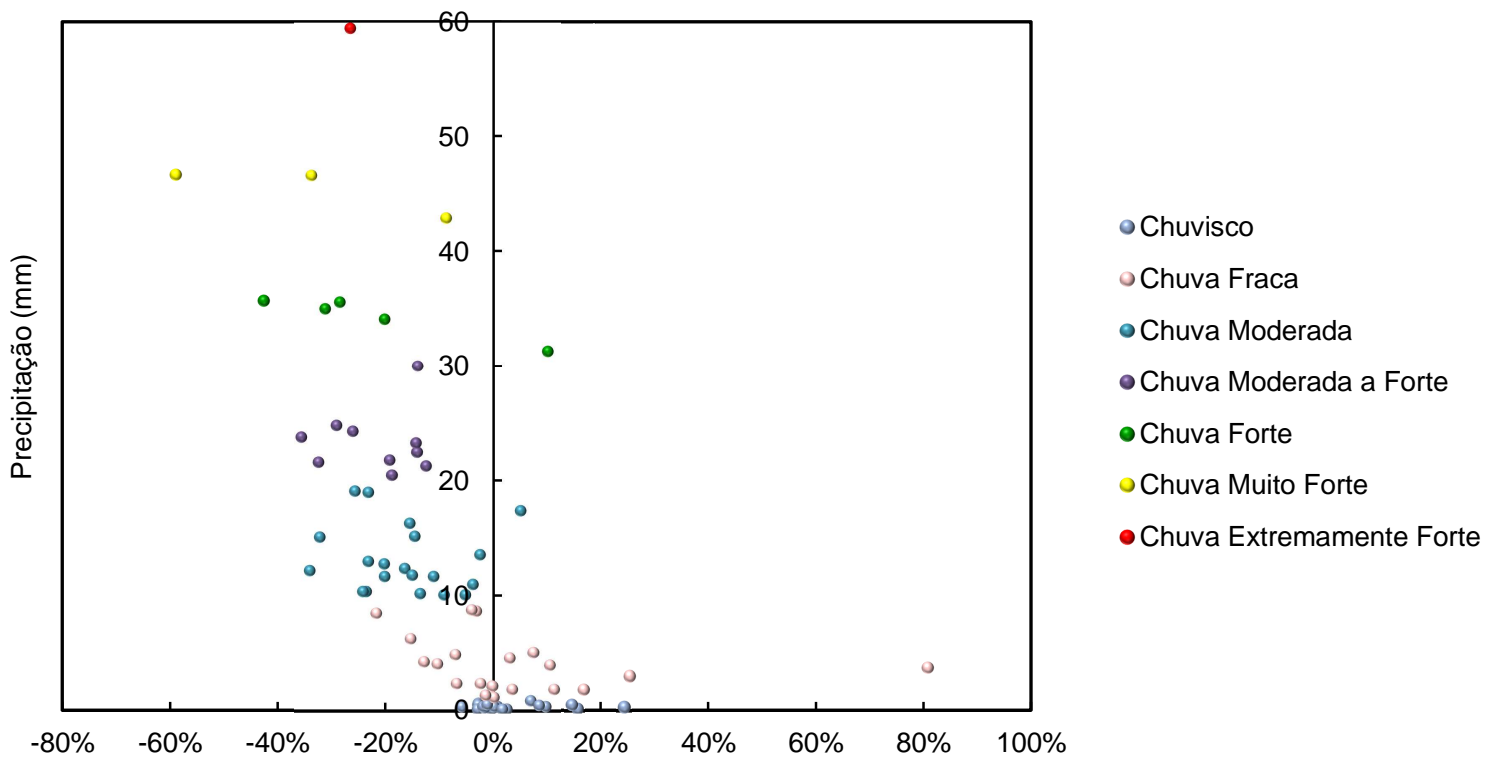

Figura 38 - Variação de vazão de biogás em relação ao dia anterior em função do volume de chuva do dia analisado.

Fonte: A Autora.

Considerando os dados apresentados é possível perceber que a precipitação é um fator que pode reduzir significativamente a produção de biogás, e que conforme é maior a intensidade da chuva, maior pode ser essa redução.

Considerando que na bacia de atendimento dessa ETE, em 16\% do período de análise houve chuvas superiores a $5 \mathrm{~mm}$, e a redução média de vazão com relação ao dia anterior nesses eventos foi de 21,9\%, pode-se estimar que a vazão média de biogás da ETE pode ter sido 3,5\% menores devido às chuvas. No entanto, como o evento de chuva é aleatório, esse valor pode ser maior em épocas com elevada precipitação.

Também foi realizada essa análise para os casos em que há mais de um dia consecutivo de chuva, utilizando para isso a média da pluviosidade do período. Percebe-se que nos casos de "chuva moderada a forte" houve redução média significativa da vazão de biogás, em média de 39\%. Considerando "chuva moderada", essa redução foi de aproximadamente 33\%. Apenas nos casos de chuvas fracas houve três eventos que não causaram redução de biogás. Esses eventos representaram precipitações abaixo de $5 \mathrm{~mm}$ por dia, indicando que chuvas inferiores a $5 \mathrm{~mm}$ podem não influenciar diretamente na produção de biogás da ETE. Na Figura 39, o eixo y apresenta o volume de chuva médio de cada período (em dias consecutivos) e o eixo x a variação de vazão de biogás do último dia de chuva em 
relação ao dia anterior sem chuva. O raio da circunferência representa a quantidade de dias de chuva consecutivos.

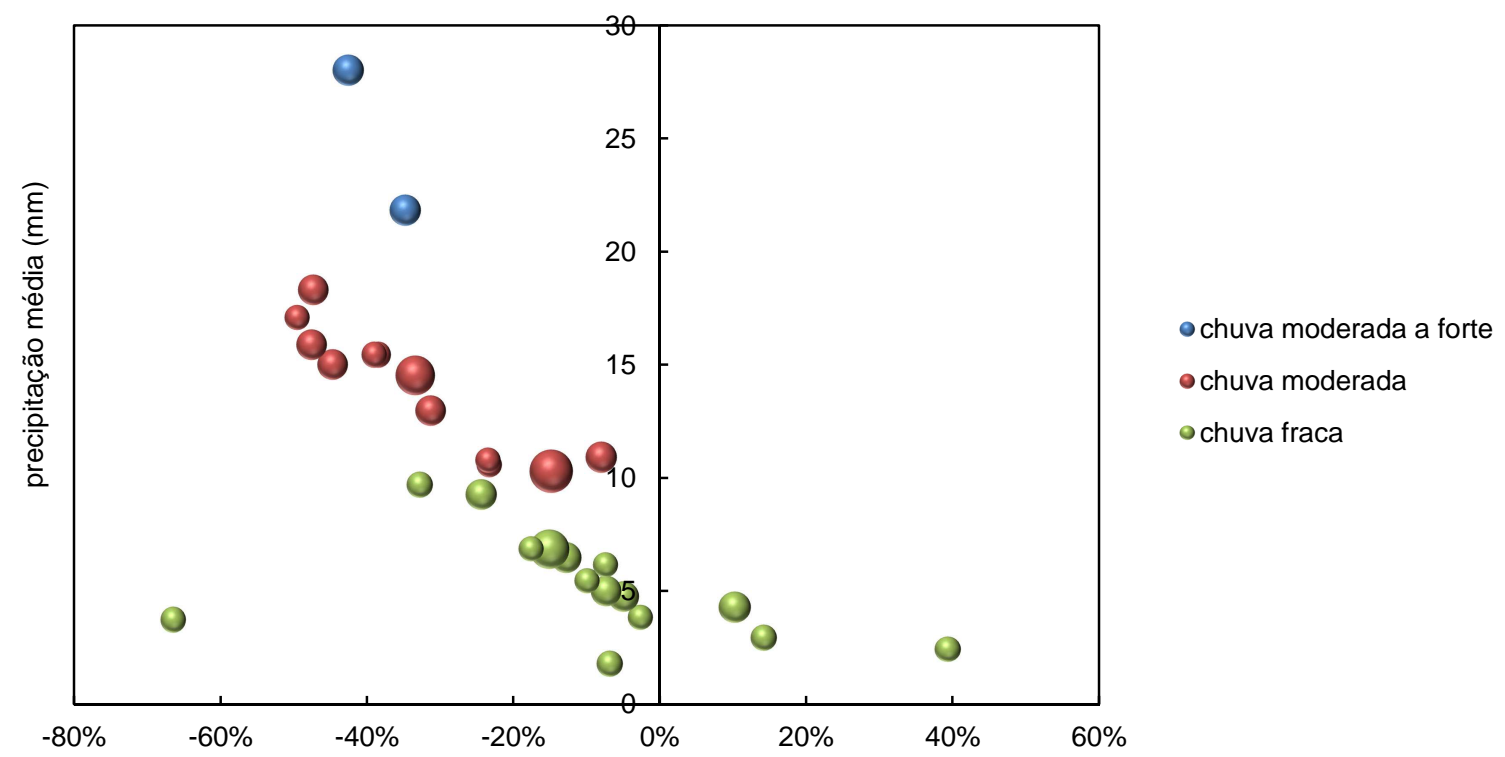

Figura 39 - Relação entre os eventos consecutivos de chuva e redução na vazão de biogás do último dia de chuva em relação ao dia anterior sem chuva.

Fonte: A Autora.

Nas outras 248 ocorrências, consideradas ausência de chuva ou chuvisco ocorreram reduções de vazão de biogás em 97 dias, valor que representa 39\% das ocorrências. Nesse caso a redução foi, em média, de 4,3\%, com máxima de 17,9\%. Essa variação pode ter sido motivada por diversos fatores, tais como, como descarga de lodo do reator e limpeza de escuma, além de alterações na carga orgânica recebida pela ETE.

Também foi analisada a variação de vazão de biogás um dia após o evento de chuva, conforme é mostrado na Figura 40. O eixo y reporta o volume de chuva do dia anterior e o eixo x ilustra a variação de vazão de biogás. Foram 63 eventos de pós-chuva, sendo que em apenas 13 eventos $(20,6 \%)$ não houve aumento de vazão de biogás logo depois de encerrado o evento de chuva. No entanto, analisando esses 13 eventos, percebeu-se que um deles foi de chuva extremamente forte, e o aumento de vazão se deu no segundo dia após o término da chuva. Os outros três pontos foram de chuva fraca, todas abaixo de $5 \mathrm{~mm}$, e os outros nove pontos são referentes à chuviscos.

O ponto referente à chuva extremamente forte sofreu uma redução de $26,5 \%$ em relação ao início da chuva. Um dia depois da chuva ele reduziu mais $9 \%$ em relação ao dia da 
chuva. Apenas no segundo dia após o evento de chuva, a vazão de biogás voltou a aumentar sendo majorada em $13,8 \%$ em relação ao dia em que ocorreu a chuva.

$\mathrm{O}$ ponto referente à chuva muito forte teve sua vazão aumentada em $15 \%$ após o término do evento de chuva e os pontos referentes à chuva forte tiveram sua vazão aumentada em média $36 \%$ após o término do evento de chuva, bem como um dia após a chuva moderada a forte, quando houve uma redução média de $23 \%$. Já os sete pontos referente à chuva moderada, indicam um aumento de vazão médio de $13 \%$ após o evento de chuva.

Dos 19 pontos referentes à chuva fraca, $16(84 \%)$ registraram aumento de vazão média de $10 \%$ em relação ao dia anterior, e apenas três pontos tiveram redução de vazão mesmo após o término do evento de chuva. Esses três pontos são representados por precipitações inferiores a $5 \mathrm{~mm}$. Já os dados referentes à chuvisco tiveram distribuição aleatória que variou de $-17 \%$ até $31 \%$ de variação de vazão de biogás.

Assim, após eventos de chuva, há uma tendência de variação de vazão positiva, ou seja, uma tendência de aumento de vazão de biogás após eventos de chuva.

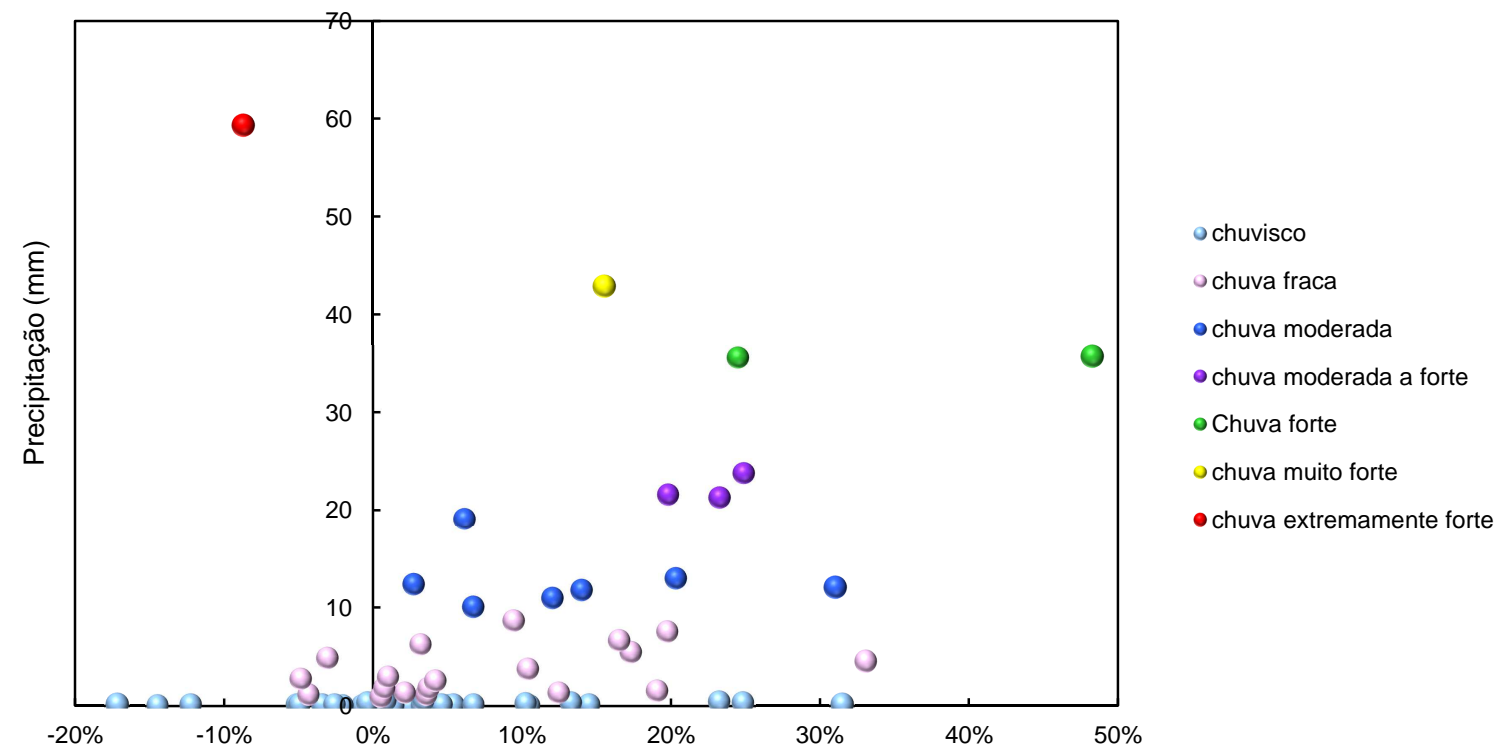

Figura 40 - Variação de vazão de biogás em relação ao dia anterior em função do volume de chuva do dia anterior ao dia analisado.

Fonte: A Autora.

Logo, pode-se concluir que há uma tendência de redução de vazão durante eventos de chuva, e há uma tendência de recuperação após o término desses eventos. Além disso, percebeu-se que essa tendência de redução de vazão de biogás foi tanto maior quanto maior 
foi a precipitação, e que eventos inferiores a $5 \mathrm{~mm}$ de chuva pouco ou nada influenciaram na variação da vazão de biogás.

De fato, há variação da vazão de biogás, independente de eventos de chuva. No entanto, os dados apresentados demonstram uma aparente correlação entre a precipitação e a redução de vazão. No entanto, é muito difícil separar os fatores que podem ou não ser correlacionados à variação de vazão de biogás em um ETE. Esses fatores podem estar ligados a operação da ETE ou características do efluente, ou ainda fatores desconhecidos, e eles podem ocorrer simultaneamente, agindo em conjunto para determinar uma situação, ou agir de forma contrária, promovendo o equilíbrio desses agentes.

Calculando a influência que os efeitos de eventos de chuva podem ter na média anual de vazão de biogás, percebe-se que a influência se torna menor, visto que em apenas $29 \%$ do tempo houve chuvas significativas, o que levaria a uma redução média de 3,44\% ao ano. No entanto, nas vazões diárias este número é maior, com média de $23,2 \%$. No caso de utilizar o biogás para aproveitamento energético este é um fator que faz com que a ETE necessite estar constantemente ligada a rede de energia elétrica, para garantir seu abastecimento mesmo em períodos com redução drástica de biogás. Além disso, esse parâmetro precisa ser levado em consideração no dimensionamento de componentes de uma planta de aproveitamento energético, em especial o gasômetro.

Extrapolando os limites desta analise, é possível concluir que em regiões onde há pouca precipitação de chuva a produção de biogás poderá ser mais constante que em regiões com altos índices pluviométricos. Considerando o caso analisado, sugere-se considerar a influência dos eventos de chuvas na concepção de eventuais projetos de aproveitamento energético de biogás.

7.4 Estimativa do potencial de produção de biogás por meio de métodos reportados na literatura e comparação com os resultados de medições realizadas em campo

Uma vez estimadas as vazões de biogás e de metano disponível para utilização na ETE Atuba Sul, esses resultados foram confrontados com os resultados estimados de taxas de produção de biogás por meio de métodos reportados na literatura, como pode ser observado na Figura 41. 


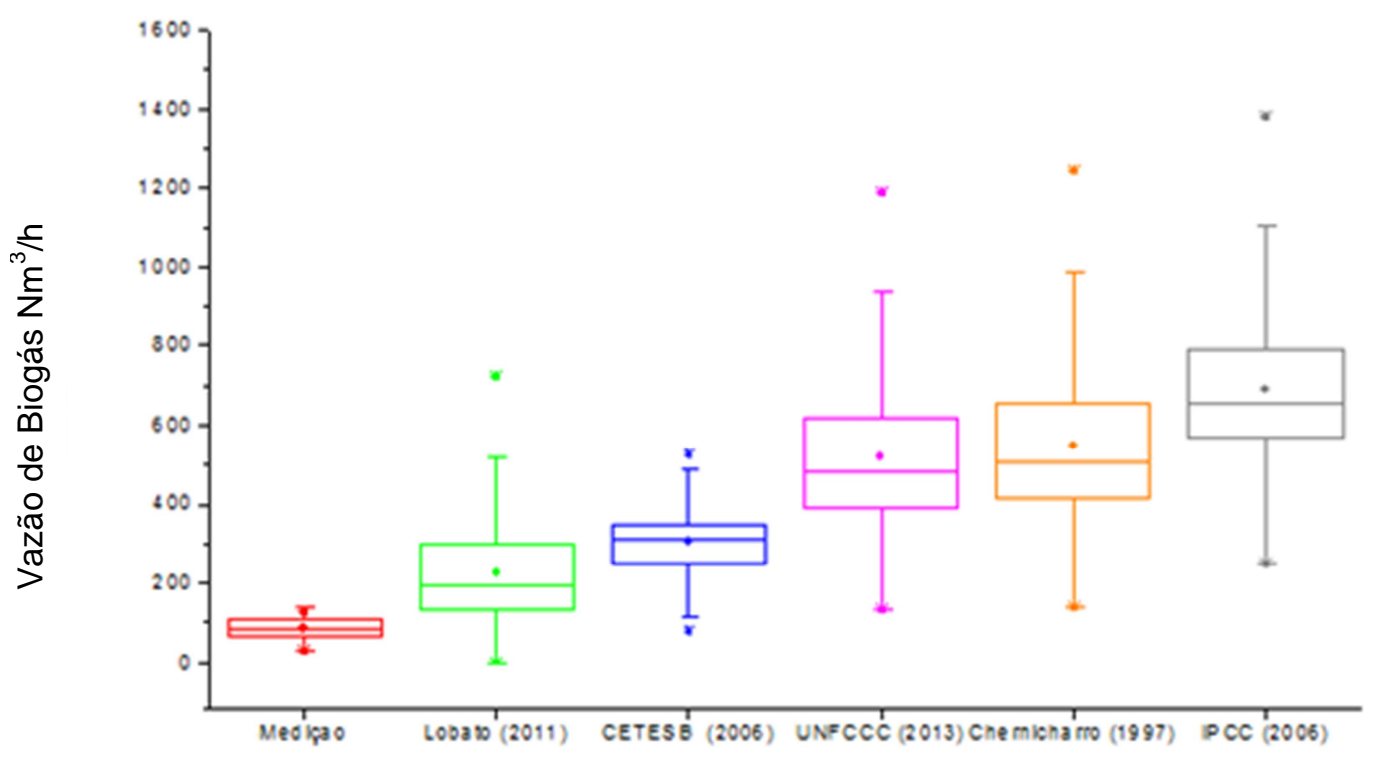

Figura 41 - Vazão média de biogás $\left(\mathrm{Nm}^{3} / \mathrm{h}\right)$ produzido e disponível nos reatores UASB da ETE Atuba Sul, de acordo com resultados de medições e de estimativas por diferentes métodos disponíveis na literatura.

Fonte: A Autora.

A vazão média anual de biogás estimada a partir do método proposto pelo IPCC (2006) foi aproximadamente 7,8 vezes maior que aquela obtida a partir de medições, mesmo com a adequação paramétrica do modelo. Essa diferença foi ainda mais significativa quando o histórico de dados de vazão e de DQO de esgoto não foi utilizado. A vazão média anual de biogás estimada sem as adequações do modelo, ou seja, considerando Pop $=411.862$ habitantes, $\mathrm{QPCDBO}=50 \mathrm{gDBO} / \mathrm{hab}$.dia, $\mathrm{B} 0=0,6 \mathrm{kgCH}_{4} / \mathrm{kgDBOremov}, \mathrm{MCF}=0,8$ e $\mathrm{EF}=$ 0,48 $\mathrm{kgCH}_{4} / \mathrm{kgDBOremov}$, foi de $957,4 \mathrm{Nm}^{3} /$ hora. Esse valor é, pelo menos, 10 vezes maior que aquele encontrado por meio de medições.

Por sua vez, a produção média anual de energia calculada por meio dos métodos sugeridos pela UNFCCC (2013) e por Chernicharo (1997) foram, respectivamente, 5,9 e 6,2 vezes maiores que aquela mensurada, apesar desses modelos considerarem a vazão de esgoto, a eficiência de remoção de DQO do esgoto nos reatores UASB e a conversão parcial da DQO em lodo, no caso do modelo de Chernicharo (1997) ou o fator de incerteza, no caso do método do UNFCCC (2013).

Também o método reportado pela CETESB (2006), resultou em uma estimativa em média 3,3 vezes maior que aquela encontrada por meio de medições de vazão na ETE. Apesar desses resultados estarem um pouco mais próximos da realidade, quando o modelo foi 
calculado apenas com os dados sugeridos pelo próprio modelo (o resultado pode ser até 40 vezes maior que aquele obtido nas medições de campo).

Portanto, os métodos reportados pelo IPCC (2006), pelo UNFCCC (2013), por Chernicharo (1997) e pela CETESB (2006), superestimaram o valor médio anual de vazão de biogás na ETE Atuba Sul. Isso aconteceu porque esses métodos não consideram importantes rotas de conversão de DQO inerentes aos reatores UASB, assim como não pressupõem perdas de metano.

Essas premissas, no entanto, são incorporadas no método proposto por Lobato (2011) e, consequentemente, a diferença entre a vazão média de biogás estimada com tal método e o valor médio obtido por meio das medições foi minimizada. Mesmo assim, a produção anual de biogás estimada foi, em média, 2,4 vezes maior que aquela determinada a partir de medições.

Ainda utilizando o modelo proposto por Lobato (2011), foi possível calcular que, em média, apenas $47 \%$ da DQO presente no esgoto é convertida em metano, o que indica que $53 \%$ da DQO afluente pode ter saído solubilizada no efluente, e somente $42 \%$ do metano produzido nos reatores UASB (ou 19\% da DQO convertida em biogás) pode ser disponibilizado para aproveitamento energético, ou seja, foi coletada no separador trifásico e disponível para utilização (Figura 42), indicando que houve perdas, seja dissolvido no efluente, ou por desprendimento para a atmosfera.

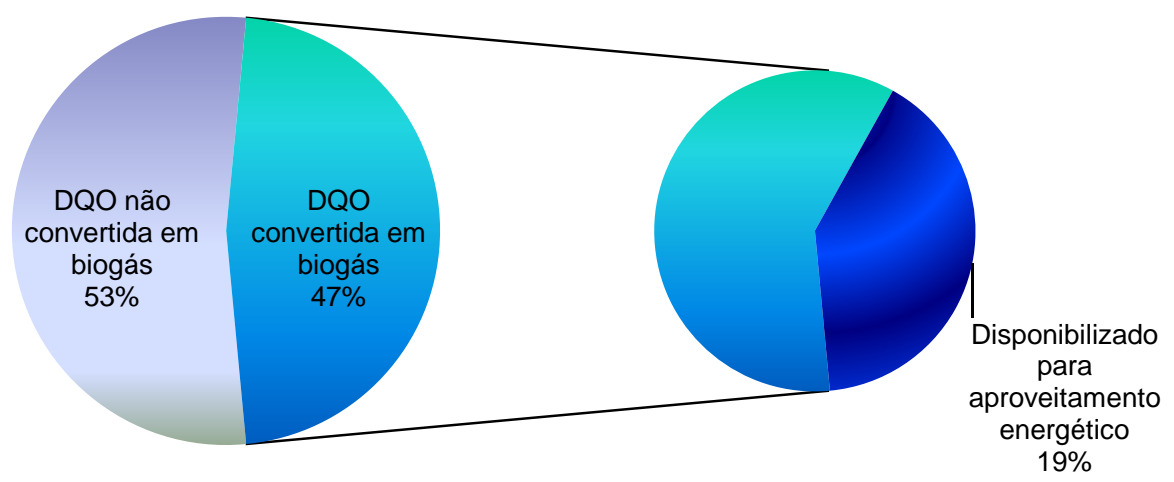

Figura 42 - Estimativa da conversão da DQO em $\mathrm{CH}_{4}$

Fonte: A Autora.

Portanto, se considerar este modelo, percebe-se que há ainda um grande potencial de biogás que tipicamente se perde e que se fosse recuperado poderia majorar a produção de biogás. Isso explica porque as estimativas são pouco acuradas. 
É importante ressaltar que as incertezas inerentes às estimativas não podem ser negligenciadas, uma vez que elas variaram de $( \pm 86,07)$ até $( \pm 205,45) \mathrm{Nm}^{3} /$ hora. Além disso, por meio do box plot ilustrado na Figura 41 e da Tabela 17 é possível fazer uma análise mais detalhada dos dados de vazão disponível.

Tabela 17 - Comparação entre os dados adquiridos em campo e aqueles calculados por métodos reportados na literatura.

\begin{tabular}{ccccccc}
\hline $\begin{array}{c}\text { Método } \\
\left(\mathrm{Nm}^{3} \text { /hora }\right)\end{array}$ & Dados de & Lobato & CETESB & UNFCCC & Chernicharo & IPCC \\
\hline Média & 84,30 & 225,26 & 303,26 & 518,99 & 546,75 & 688,63 \\
Mediana & 85,33 & 198,31 & 310,00 & 485,69 & 511,17 & 656,62 \\
Máximo & 136,52 & 722,74 & 524,26 & 1189,12 & 1245,74 & 1379,58 \\
Mínimo & 28,17 & 0,06 & 76,97 & 133,35 & 139,22 & 247,77 \\
$1^{\circ}$ Quartil & 66,51 & 133,31 & 253,43 & 393,99 & 415,05 & 571,69 \\
$3^{\circ}$ Quartil & 108,25 & 299,71 & 348,99 & 614,34 & 652,28 & 786,31 \\
Desvio Padrão & 26,64 & 143,71 & 86,07 & 194,27 & 205,45 & 202,85 \\
Coeficiente De & 0,32 & 0,64 & 0,28 & 0,37 & 0,38 & 0,29 \\
Variação & & & & & & \\
\hline
\end{tabular}

Os dados adquiridos em campo apresentaram um perfil bastante simétrico, inclusive com a média bastante próxima da mediana e não apresentaram pontos discrepantes, visto que os pontos extremos estão dentro da cauda de distribuição. Além disso, o coeficiente de variação, dado pela razão entre o desvio padrão e o valor médio, foi de $32 \%$, um valor que, em princípio, indica heterogeneidade e alta dispersão. No entanto, esse valor é semelhante àqueles inerentes aos modelos.

Os cinco modelos apresentados apresentaram assimetria nos dados e outliers, o menor coeficiente de variação aparece no modelo proposto pela Cetesb (2016), que variou 28\% enquanto o maior coeficiente de variação aparece no modelo proposto por Lobato (2011), com valor de 64\%. O modelo mais acurado também foi aquele proposto por Lobato (2011), que teve sua mediana mais próxima da mediana dos dados mensurados em campo, enquanto o modelo menos acurado foi o proposto pelo IPCC (2006) que teve sua mediana mais distante da mediana dos dados de campo.

Assim, considerando-se as incertezas inerentes às estimativas, pode-se afirmar que a faixa de vazão de biogás determinada por meio de medições está contida no intervalo estimado por meio do método proposto por Lobato (2011). Logo, esse método foi o que 
melhor representou as quantidades de biogás e, consequentemente, de energia que podem ser recuperadas dos reatores UASB da ETE Atuba Sul.

As incertezas em pauta estão diretamente relacionadas com as eventuais mudanças nas condições operacionais da ETE e com a variação das propriedades físicas e químicas do esgoto que entra nos reatores UASB ao longo do ano, as quais possuem natureza aleatória e são criticamente dependentes de eventos de chuvas (Possetti et al., 2013).

Também se deve atentar para as diferenças inerentes aos modelos. Quando são utilizados parâmetros preconizados na literatura como fonte de dados para realizar as estimativas, os valores de vazão de biogás obtidos são maiores do que quando são utilizados os valores coletados na ETE, o que demonstra a importância em se adquirir dados em campo.

Uma vez mensuradas e/ou estimadas as vazões de biogás, calculou-se a vazão de metano disponível para utilização. Para isso foi utilizada a média dos valores adquiridos em campo, e, por consequência, pode-se estimar a potência química disponível para aproveitamento energético do biogás produzido em tais reatores, utilizando o poder calorífico equivalente. Assim, a taxa média de produção de metano encontrada foi de $(53,13 \pm 15,04)$ $\mathrm{Nm}^{3} / \mathrm{h}$ e a potência química média foi de $(526,04 \pm 166,24) \mathrm{kW}$. A Tabela 18 apresenta os valores adquiridos calculados para a vazão média de biogás, vazão média de metano e potência química disponível segundo os dados encontrados por meio da medição e segundo os métodos reportados na literatura. Percebe-se que a potência química é proporcional à vazão de biogás e de metano, e assim como ocorreu com as estimativas para biogás, os valores calculados de potência química adquiridos por meio dos modelos superestimam os dados verificados em campo.

Tabela 18 - Produções médias anuais de biogás e potência química disponível

\begin{tabular}{cccc}
\hline Método & $\begin{array}{c}\text { Vazão de biogás } \\
\left(\mathrm{Nm}^{3} / \mathrm{h}\right)\end{array}$ & $\begin{array}{c}\text { Vazão de metano } \\
\left(\mathrm{Nm}^{3} / \mathrm{h}\right)\end{array}$ & $\begin{array}{c}\text { Potência química } \\
\text { disponível }(\mathrm{kW})\end{array}$ \\
\hline Dados de campo & $84,30 \pm 26,64$ & $53,13 \pm 15,04$ & $526,04 \pm 166,24$ \\
Lobato (2011) & $225,26 \pm 143,71$ & $181,99 \pm 141,47$ & $1801,07 \pm 882,80$ \\
CETESB (2006) & $303,26 \pm 86,07$ & $176,18 \pm 51,64$ & $1744,18 \pm 537,11$ \\
UNFCCC (2013) & $519,99 \pm 194,27$ & $311,4 \pm 116,56$ & $3082,86 \pm 1.212,22$ \\
Chernicharo (1997) & $546,75 \pm 205,45$ & $328,05 \pm 123,27$ & $3.247,69 \pm 1.282,01$ \\
IPCC (2006) & $688,63 \pm 202,85$ & $413,18 \pm 121,71$ & $4.090,48 \pm 1265,81$ \\
\hline
\end{tabular}


As relações unitárias de produção de metano, de biogás e de energia em reatores UASB tratando esgoto tipicamente doméstico também puderam ser quantificadas (Tabela 19) e comparadas com o as relações unitárias propostas por Lobato (2011).

Tabela 19- Relações unitárias de produção de metano, de biogás e de energia em reatores UASB tratando esgoto doméstico

\begin{tabular}{|c|c|c|c|c|c|c|c|}
\hline \multirow{2}{*}{$\begin{array}{l}\text { Relação } \\
\text { unitária }\end{array}$} & \multirow{2}{*}{ Unidade } & \multicolumn{3}{|c|}{ Medido } & \multicolumn{3}{|c|}{ Lobato (2011) } \\
\hline & & Máximo & Mínimo & Média & Máximo & Mínimo & Média \\
\hline \multirow{3}{*}{$\begin{array}{l}\text { Volume } \\
\text { unitário de } \\
\mathrm{CH}_{4} \\
\text { produzido }\end{array}$} & NL.hab ${ }^{-1} \cdot$ dia $^{-1}$ & 4,64 & 0,96 & 2,87 & 16,7 & 3,6 & 10,2 \\
\hline & NL.m ${ }^{-3}$ esgoto & 22,94 & 4,73 & 14,16 & 134,6 & 16,7 & 64,2 \\
\hline & $\mathrm{NL.kgDQO}_{\text {remov }}^{-1}$ & 69,21 & 14,28 & 42,74 & 219,1 & 66,0 & 158,3 \\
\hline \multirow{3}{*}{$\begin{array}{c}\text { Volume } \\
\text { unitário de } \\
\text { biogás } \\
\text { produzido }\end{array}$} & NL.hab ${ }^{-1} \cdot$ dia $^{-1}$ & 7,77 & 1,60 & 4,80 & 20,8 & 5,2 & 13,6 \\
\hline & NL.m ${ }^{-3}$ esgoto & 38,38 & 7,92 & 23,70 & 168,3 & 23,8 & 85,6 \\
\hline & NL.kgDQO remov $^{-1}$ & 115,82 & 23,89 & 71,52 & 273,9 & 94,3 & 211,1 \\
\hline \multirow{4}{*}{$\begin{array}{l}\text { Potêncial } \\
\text { químico } \\
\text { energético } \\
\text { unitário }\end{array}$} & kWh.m-3 esgoto & 0,24 & 0,05 & 0,15 & 1,3 & 0,2 & 0,6 \\
\hline & kWh.kgDQO remov $^{-1}$ & 0,72 & 0,15 & 0,45 & 2,2 & 0,7 & 1,6 \\
\hline & kWh.Nm³ biogás & 6,24 & 6,24 & 6,24 & 8,0 & 7,0 & 7,5 \\
\hline & kWh.hab ${ }^{-1} \cdot$ ano $^{-1}$ & 17,70 & 3,65 & 10,93 & 60,7 & 24,9 & 37,2 \\
\hline
\end{tabular}

Observa-se que os reatores UASB da ETE Atuba Sul apresentam uma produção volumétrica estimada de biogás média de $4,8 \mathrm{NL} \cdot \mathrm{hab}^{-1} \cdot \mathrm{d}^{-1}$, produção essa menor que a reportada por Lobato (2011) que encontrou uma produção estimada de biogás variando entre 5,2 e $20,8 \mathrm{NL} \cdot \mathrm{hab}^{-1} \cdot \mathrm{d}^{-1}$.

Ainda de acordo de acordo com as relações unitárias obtidas nas simulações efetuadas por Lobato (2011), para os reatores UASB estima-se uma produção média de metano variando entre 66,0 e 219,1 NL.CH $4 . \mathrm{kg} \mathrm{DQO}_{\text {removida }}{ }^{-1}$. Para a ETE Atuba Sul verificou-se uma produção média de biogás de $42,74 \mathrm{NL} . \mathrm{CH}_{4} \cdot \mathrm{kg} \mathrm{DQO}_{\text {removida }}{ }^{-1}$, valor inferior ao reportado nos estudos de Lobato (2011).

O potencial de recuperação de energia química nos reatores UASB foi de $(0,15 \pm 0,04)$ $\mathrm{kWh}$ por $\mathrm{m}^{3}$ de esgoto tratado, valor inferior aos $0,6 \mathrm{kWh}$ por $\mathrm{m}^{3}$ de esgoto tratado reportado por Lobato (2011).

Finalmente, é importante mencionar que a faixa de geração média de metano estimada pelo modelo variou entre 0,01 e $0,07 \mathrm{Nm}^{3} \mathrm{CH}_{4} \cdot \mathrm{kgDQO}_{\text {removida }}{ }^{-1}$. Essses valores são menores que aqueles reportados por Noyola, Capdeville e Roques. (1988), cujos valores variaram entre 0,08 e $0,18 \mathrm{Nm}^{3} \cdot \mathrm{kgDQO}_{\text {removida }}{ }^{-1}$. 
7.5 Avaliação dos custos evitados ao aproveitar o biogás para geração de energia elétrica

O contrato para atendimento da demanda energética da ETE Atuba Sul faz parte do Grupo A4, com tensão de fornecimento de 2.300 a $25.000 \mathrm{~V}$, a demanda de potência ativa contratada é de $400 \mathrm{~kW}$. A maior demanda medida no período foi de $308 \mathrm{~kW}$. A modalidade tarifária adotada é a horo-sazonal verde, ou seja, a aplicação de tarifas de consumo de energia elétrica e de demanda de potência é diferenciada de acordo com as horas de utilização do dia e dos períodos do ano, bem como possui uma única tarifa de demanda de potência (ANEEL, 2014c).

No período que compreende outubro/2011 a junho/2012, as tarifas estavam respaldadas pela Resolução 1158/2011 da ANEEL, que determinava tarifas de ponta, fora de ponta, seca e úmida, como pode ser visto na Tabela 20.

Tabela 20 - Tarifas praticadas pela empresa distribuidora de energia para o sistema horo-sazonal verde, grupo A4 no período entre julho de 2011 e junho e 2012.

\begin{tabular}{ccc}
\hline Tarifas & $\begin{array}{c}\text { Resolução } \\
\text { ANEEL }\end{array}$ & $\begin{array}{c}\text { Com Impostos: ICMS } \\
\text { e PIS/COFINS }\end{array}$ \\
\hline Demanda $(\mathrm{R} \$ / \mathrm{kW})$ & 9,04 & 10,2 \\
Demanda Ultrapassagem $(\mathrm{R} \$ / \mathrm{kW})$ & 18,08 & 20,4 \\
Consumo $(\mathrm{R} \$ / \mathrm{kWhe})$ Ponta seca & 1,03291 & 1,36247 \\
Consumo (R\$/kWhe) Ponta úmida & 1,01203 & 1,33482 \\
Consumo (R $\$ / \mathrm{kWhe})$ Fora de Ponta seca & 0,14562 & 0,19208 \\
Consumo (R $\$ / \mathrm{kWhe})$ Fora de Ponta úmida & 0,13351 & 0,17611 \\
\hline
\end{tabular}

Já no período entre julho de 2012 e outubro de 2012, as tarifas estavam respaldadas pela Resolução ANEEL 1296/2012, que determinava tarifas de ponta e tarifas fora de ponta como pode ser visto na Tabela 21. 
Tabela 21 - Tarifas praticadas pela empresa de energia para o sistema horo-sazonal verde, grupo A4, no período entre julho de 2012 a outubro de 2012.

\begin{tabular}{ccc}
\hline Tarifas & $\begin{array}{c}\text { Resolução } \\
\text { ANEEL }\end{array}$ & $\begin{array}{c}\text { Com Impostos: ICMS } \\
\text { e PIS/COFINS }\end{array}$ \\
\hline Demanda $(\mathrm{R} \$ / \mathrm{kW})$ & 6,59 & 8,10 \\
Demanda Ultrapassagem $(\mathrm{R} \$ / \mathrm{kW})$ & 13,18 & 16,2 \\
Consumo $(\mathrm{R} \$ / \mathrm{kWhe})$ Ponta & 0,80991 & 1,05645 \\
Consumo $(\mathrm{R} \$ / \mathrm{kWhe})$ Fora de Ponta & 0,16448 & 0,21696 \\
\hline
\end{tabular}

No mesmo período, a ETE Atuba Sul apresentou um consumo médio de energia elétrica mensal de 114.374 kWhe/mês, sendo 103.414 kWhe/mês em horário fora de ponta e $10.960 \mathrm{kWhe} / \mathrm{mês}$ em horário de ponta (Figura 43). Dessa forma, percebeu-se que no mês junho de 2012 houve um significativo aumento de consumo de energia pela ETE, que é justificado pela operação contínua e rotineira de um flotador, com alto consumo energético.

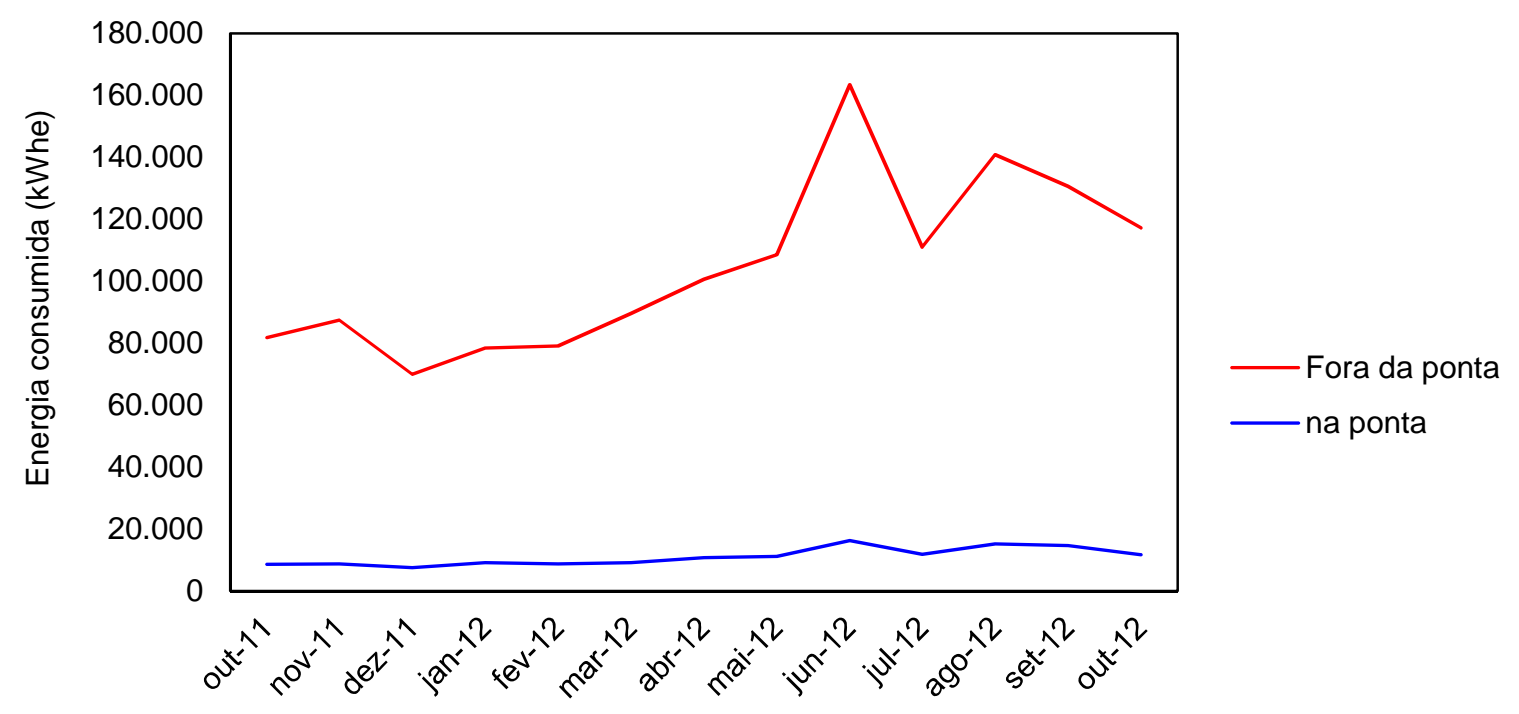

Figura 43 - Histórico de consumo de energia elétrica da ETE Atuba Sul para o período entre 01/10/2011 e $01 / 10 / 2012$.

No mesmo período, a ETE Atuba Sul apresentou um custo médio mensal de R\$ 34.211, sendo $\mathrm{R} \$ 20.487$ em horário fora de ponta e $\mathrm{R} \$ 13.724$ em horário de ponta. Percebese que (Figura 44) o custo da energia consumida mensalmente em horário de ponta acompanha o custo de energia em horário de ponta, diferenciando um pouco os valores a partir de junho, quando passou a valer novas tarifas de energia. 


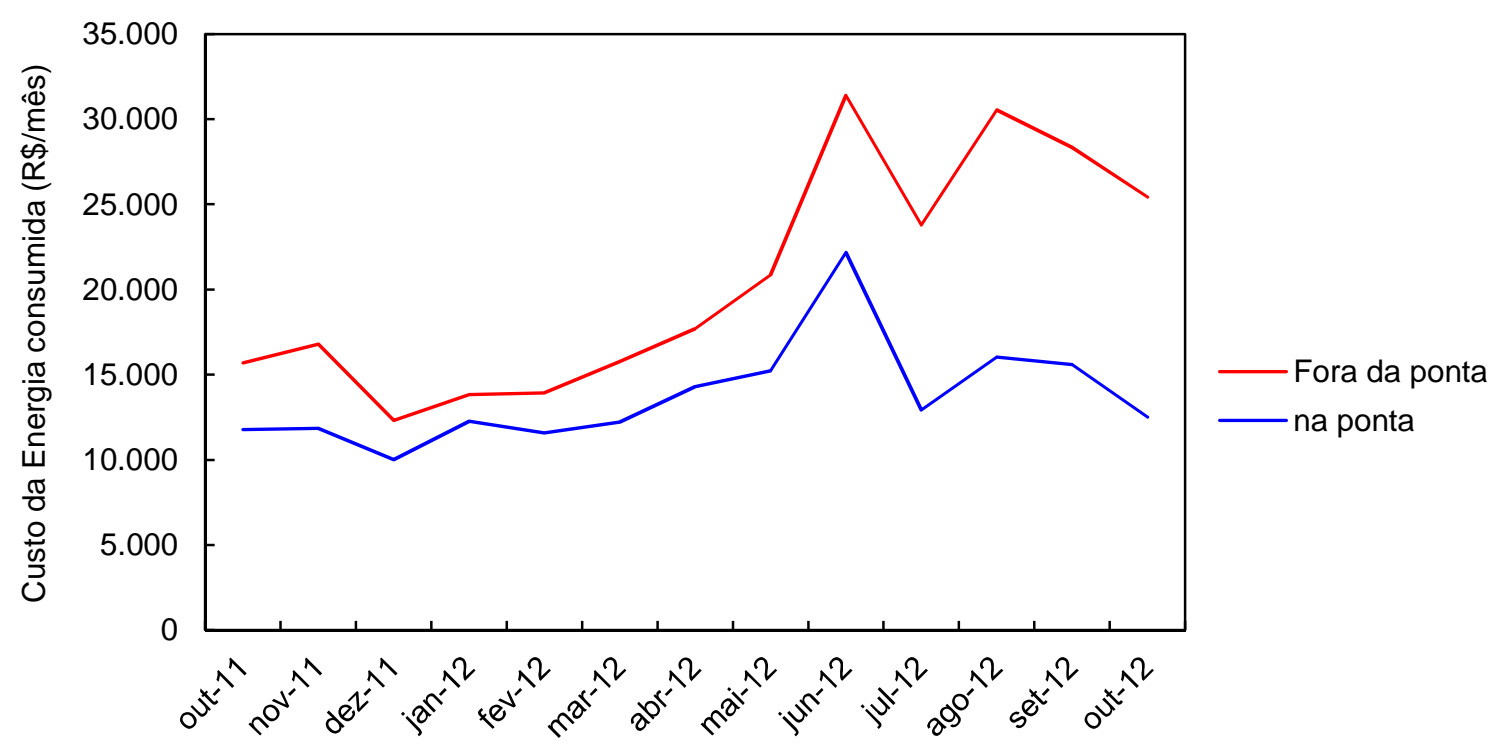

Figura 44 - Histórico do custo de energia elétrica da ETE Atuba Sul para o período entre 01/10/2011 e $01 / 10 / 2012$.

A geração de energia elétrica a partir da recuperação do biogás foi estimada para a ETE Atuba Sul, considerando o rendimento médio dos equipamentos de conversão de energia, do tipo motores de combustão interna igual, a 33\% (PECORA, 2006) e, priorizando a geração de energia elétrica em horário de ponta. No período, a ETE Atuba Sul teve sua potência elétrica máxima calculada em $233 \mathrm{~kW}$, o que conforme a Resolução Normativa $\mathrm{n}^{\circ}$ 482 da ANEEL, poderia ser classificada como minigeração distribuída. Se a geração de energia fosse constante ( 24 horas), e utilizando os valores oriundos da medição de cada mês, poderia gerar 1.500.632 kWhe/ano. Considerando que o consumo de energia elétrica da rede nesse mesmo intervalo de tempo foi de 1.372.489 kWhe/ano, então haveria excedente de energia de $128.143 \mathrm{kWhe/ano.} \mathrm{A} \mathrm{energia} \mathrm{elétrica} \mathrm{consumida} \mathrm{pela} \mathrm{ETE} \mathrm{e} \mathrm{fornecida} \mathrm{pela}$ concessionária local e a energia elétrica hipoteticamente gerada na ETE Atuba Sul a partir da recuperação do biogás pode ser vista na Figura 45. 


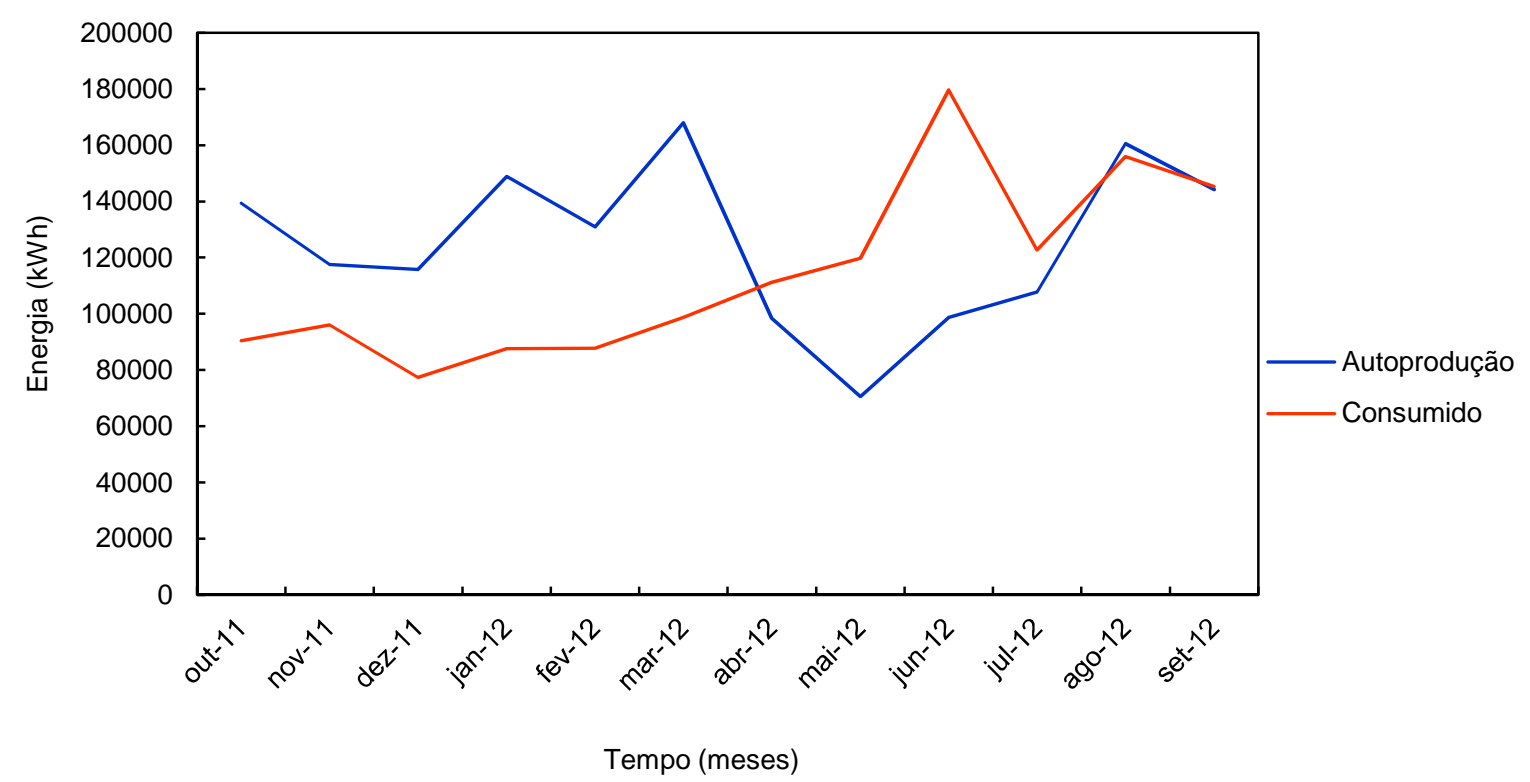

Figura 45 - Energia elétrica consumida e energia elétrica hipoteticamente gerada com biogás pela ETE Atuba Sul no período em análise.

Fonte: A Autora.

Assim, a ETE Atuba Sul teve a capacidade de atender toda a sua demanda de energia elétrica nos meses de outubro de 2011 até março de 2012 e no mês de agosto de 2012, enquanto nos meses de abril a julho e setembro de 2012, a geração de energia elétrica foi inferior à energia demandada, o que indica que tanto a geração de energia quanto a demanda de energia da ETE são bastante variáveis ao longo do tempo. A maior variação de energia consumida na ETE está relacionada à utilização do flotador, como já explicado anteriormente, enquanto que a variação na energia elétrica está relacionada à disponibilidade de biogás, que entre abril e julho foi menor.

Considerando a aplicação do primeiro cenário, de autoprodução de energia elétrica sem injeção do excedente na rede de distribuição de energia elétrica verificou-se uma diminuição acentuada na autoprodução nos meses de março a maio de 2012, a qual se normaliza a partir de julho de 2012. Nesse mesmo período é necessário consumir energia da rede (Figura 46). 


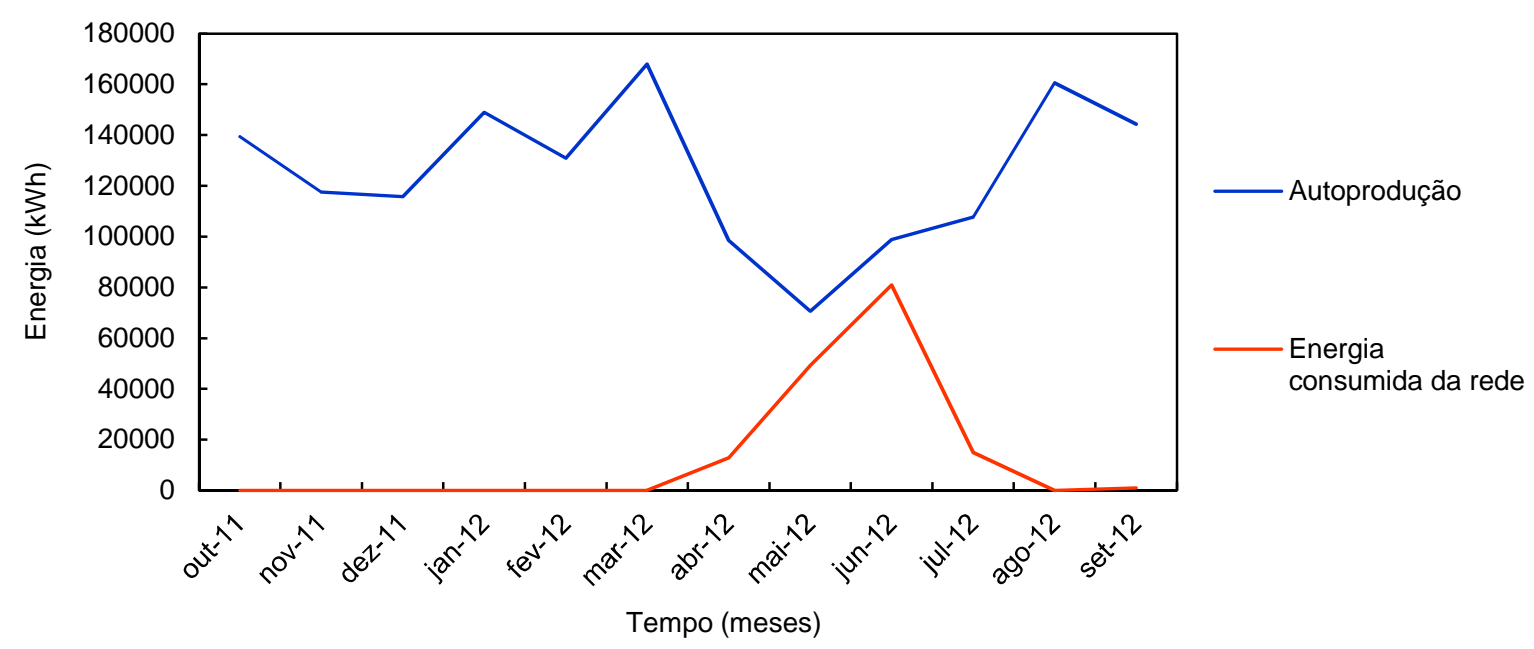

Figura 46 - Energia consumida na ETE Atuba Sul com utilização da energia elétrica produzida na própria ETE.

Fonte: A Autora.

Apesar de não ser possível atender toda a necessidade energética da ETE por 100\% do tempo, a autoprodução de energia evitaria aproximadamente o consumo de 131.525 kWhe/ano em horário de ponta e 1.369.107 kWhe/ano fora do horário de ponta, o que financeiramente significaria que a ETE poderia evitar um custo de aproximadamente R \$397.381,05 no período avaliado. Nesse cenário possíveis excedentes de energia não seriam aproveitados (Tabela 22).

Tabela 22 - Potencial de autoprodução mensal de energia elétrica e custo mensal evitado.

\begin{tabular}{cccc}
\hline Mês & Autoprodução na ponta & Autoprodução fora da ponta & Custo evitado (R\$) \\
\hline out-11 & $8.650,00$ & $130.657,29$ & $36.882,11$ \\
nov-11 & $8.690,00$ & $108.930,25$ & $32.763,25$ \\
dez-11 & $7.495,00$ & $108.250,58$ & $29.068,96$ \\
jan-12 & $9.189,00$ & $139.663,01$ & $36.862,27$ \\
fev-12 & $8.680,00$ & $122.184,86$ & $33.104,76$ \\
mar-12 & $9.151,00$ & $158.755,62$ & $40.173,89$ \\
abr-12 & $10.703,00$ & $87.743,31$ & $27.489,85$ \\
mai-12 & $11.165,00$ & $59.387,89$ & $17.173,23$ \\
jun-12 & $16.277,00$ & $82.484,97$ & $22.475,34$ \\
jul-12 & $11.773,00$ & $95.995,95$ & $30.316,54$ \\
ago-12 & $15.167,00$ & $145.377,52$ & $47.564,03$ \\
set-12 & $14.585,00$ & $129.676,12$ & $43.506,81$ \\
\hline Total & $131.525,00$ & $1.369 .107,37$ & $397.381,05$ \\
\hline
\end{tabular}


No segundo cenário, por sua vez, foi considerada a suposta adoção da Resolução Normativa $n^{\circ} 482$ da ANEEL, que prevê a injeção do excedente de energia na rede para posterior compensação, visto que no período, os meses de outubro de 2011 a março de 2012 e o mês de agosto poderiam gerar excedente de energia suficiente para compensar toda a energia necessária para a operação da ETE Atuba Sul no período avaliado, com sobra para abater energia de outra ETE do sistema, como pode ser visualizado na Tabela 23.

Tabela 23 - Custos evitados pela compensação energética.

\begin{tabular}{cccc}
\hline mês & $\begin{array}{c}\text { Energia consumida } \\
\text { da rede }(\mathrm{kWhe})\end{array}$ & $\begin{array}{c}\text { Excedente de } \\
\text { energia (kWhe) }\end{array}$ & $\begin{array}{c}\text { Custo evitado pela } \\
\text { compensação energética (R\$) }\end{array}$ \\
\hline out-11 & 0,00 & $48.941,29$ & 0,00 \\
nov-11 & 0,00 & $21.530,25$ & 0,00 \\
dez-11 & 0,00 & $38.332,58$ & 0,00 \\
jan-12 & 0,00 & $61.204,01$ & 0,00 \\
fev-12 & 0,00 & $43.099,86$ & 0,00 \\
mar-12 & 0,00 & $69.203,62$ & 0,00 \\
abr-12 & $12.776,69$ & 0,00 & $1.705,82$ \\
mai-12 & $49.177,11$ & 0,00 & $7.161,17$ \\
jun-12 & $80.931,03$ & 0,00 & $2.785,18$ \\
jul-12 & $14.922,05$ & 0,00 & 0,00 \\
ago-12 & 0,00 & $4.601,52$ & 158,37 \\
set-12 & 962,88 & 0,00 & $8.682,33$ \\
out-12 & $52.786,54$ & 0,00 & 23.264 .92 \\
\hline total & $158.769,76$ & $286.913,13$ & \\
\hline
\end{tabular}

Como é possível perceber, neste cenário o excedente de energia gerado foi de 286.913 $\mathrm{kWhe} / \mathrm{ano}$, enquanto a energia consumida da rede foi de $158.769 \mathrm{kWhe}$. Isso significa que por meio do sistema de compensação de energia, todo o consumo de energia elétrica da ETE poderia ser compensado e, além disso, poderia ser usada a prerrogativa de compensar parte da energia demandada por outra ETE do sistema ou outra unidade com o mesmo CNPJ.

Utilizando esse sistema, o custo evitado da autoprodução seria somado ao custo evitado com o excedente de energia, que poderia ser aproveitado por meio do sistema de compensação nos meses em que houve necessidade de consumo de energia elétrica da rede, que poderia chegar a $\mathrm{R} \$ 23.265,00$.

Considerando a questão tributária, foi calculado um terceiro cenário, no qual poderia haver a desorenação fiscal da energia elétrica consumida. Se usada essa prerrogativa, seria somado ao custo evitado da autoprodução, o custo do excedente de energia contabilizados 
sem aplicação de impostos (Tabela 24), que poderia chegar a $\mathrm{R} \$ 30.649,33$, aproximadamente $32 \%$ a mais que o verificado no cenário 2 referente ao sistema atual.

Tabela 24 - Custos evitados pela compensação energética e desorenação fiscal.

\begin{tabular}{cccc}
\hline mês & $\begin{array}{c}\text { Energia } \\
\text { consumida da } \\
\text { rede (kWhe) }\end{array}$ & $\begin{array}{c}\text { Excedente de } \\
\text { energia (kWhe) }\end{array}$ & $\begin{array}{c}\text { custo evitado pela } \\
\text { compensação } \\
\text { energética (R } \$)\end{array}$ \\
\hline out-11 & 0,00 & $48.941,29$ & 0,00 \\
nov-11 & 0,00 & $21.530,25$ & 0,00 \\
dez-11 & 0,00 & $38.332,58$ & 0,00 \\
jan-12 & 0,00 & $61.204,01$ & 0,00 \\
fev-12 & 0,00 & $43.099,86$ & 0,00 \\
mar-12 & 0,00 & $69.203,62$ & 0,00 \\
abr-12 & $12.776,69$ & 0,00 & $2.250,07$ \\
mai-12 & $49.177,11$ & 0,00 & $9.445,99$ \\
jun-12 & $80.931,03$ & 0,00 & $15.545,31$ \\
jul-12 & $14.922,05$ & 0,00 & $3.199,06$ \\
ago-12 & 0,00 & $4.601,52$ & 0,00 \\
set-12 & 962,88 & 0,00 & 208,90 \\
\hline total & $158.769,76$ & $286.913,13$ & $30.649,33$ \\
\hline
\end{tabular}

Apesar de não ser 100\% autossustentável em energia elétrica, é evidente que se tem um montante considerável de custos evitados, visto que no período a empresa pagou $\mathrm{R} \$$ 406.838,57 pela energia elétrica consumida. Caso o biogás fosse aproveitado para fins energéticos, mesmo sem injeção de excedente na rede esse valor poderia ser apenas $\mathrm{R} \$$ $9.457,52$, o equivalente a $2,32 \%$ do histórico de consumo. No caso de injetar o excedente de energia elétrica na rede para compensação esse valor seria ainda maior, pois existiria um crédito de $\mathrm{R} \$ 13.807,39$ que poderia ser abatido nos meses seguintes. $\mathrm{E}$, no caso, de adoção da prerrogativa da compensação com uma possível desorenação fiscal, o crédito poderia ser de R $\$ 21.191,80$.

Quando se utiliza a prerrogativa da Resolução Normativa nº482 da ANEEL e utiliza a energia excedente para compensação é visualizada uma diferença de $24 \%$ entre a compensação como está definida e no caso de desorenação fiscal. O PIS, cuja alíquota é de 1,65\%, e o COFINS, cuja alíquota é de 7,6\%, são submetidos ao "regime de tributação não cumulativo em que cada etapa da cadeia produtiva se apropria dos créditos decorrentes das etapas anteriores" (ANEEL, 2014b). Os seus custos são calculados mensalmente e as distribuidoras podem aplicar a tarifa final com impostos (PIS/COFINS e ICMS) sobre toda 
eletricidade consumida e, em seguida, deduzir os créditos relativos à injeção da eletricidade pelo consumidor.

Como o ICMS possui alíquota que varia entre 17 e 30\%, o peso da tributação afeta de maneira significativa o payback do investidor, o que pode desencorajar o investimento. Assim, a tributação de toda a eletricidade consumida da rede, sem levar em conta o volume que foi injetado, representa uma das maiores barreiras à difusão da micro e minigeração no Brasil.

Uma análise financeira mais detalhada poderia definir qual a melhor forma de aproveitamento do biogás para a ETE em questão, isso porque, dependendo dos custos de investimento pode ser mais viável gerar mais energia em horário de ponta e injetar o excedente na rede para compensar em outra ETE do sistema.

Outro fator que deve ser considerado é o fato de que na maior parte do tempo da análise o flotador não estava funcionando adequadamente. A operação do flotador poderia aumentar o consumo de energia elétrica da ETE, e consequentemente, poderia reduzir ou deixar de gerar excedentes de energia. Contudo, mesmo considerando essa hipótese, os custos evitados pela autoprodução de energia elétrica continuariam significativos.

Ainda há de se considerar como seriam os cenários de custos evitados para o caso de se utilizar outros métodos de estimativas (Figura 47). No caso do modelo apresentado pelo IPCC (2006), por exemplo, seria possível produzir 12.246.443 kWhe e gerar energia excedente para injeção na rede durante todo o período, em média 5 vezes a geração demandada. Isso poderia levar a acreditar que a ETE Atuba Sul poderia trabalhar como uma usina de geração de energia. 


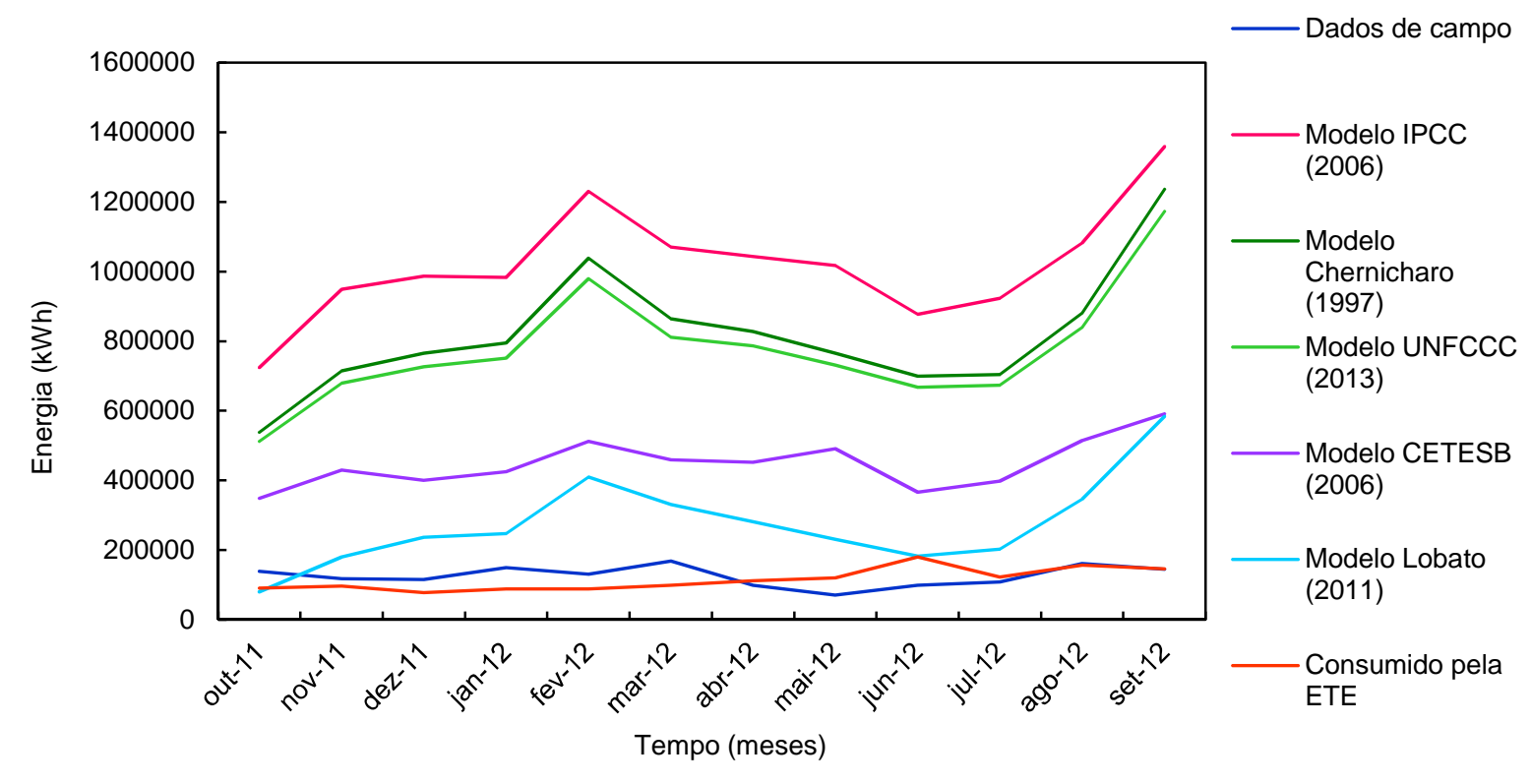

Figura 47 - Diferença entre a energia elétrica consumida e a energia elétrica gerada no período em análise na ETE por meio de medições e estimativas com diferentes modelos.

Fonte: A Autora.

No caso do modelo apresentado Chernicharo (1997), por exemplo, seria possível produzir 9.829.259 kWhe e gerar energia excedente para injeção na rede durante todo o período, em média sete vezes a geração demandada. O que também poderia levar a acreditar que a ETE Atuba Sul poderia trabalhar como uma usina de geração de energia.

O mesmo ainda ocorre quando se emprega o modelo apresentado pelo UNFCCC (2013), com o qual seria possível produzir 9.328.931 kWhe e gerar energia excedente para injeção na rede durante todo o período, em média 6,8 vezes a geração demandada. Já com o modelo apresentado pela CETESB (2006), estimou-se que seria possível produzir 5.386 .550 kWhe e gerar energia excedente para injeção na rede durante todo o período, em média 4 vezes o valor do consumo registrado.

E, considerando o modelo proposto por Lobato (2011) seria possível produzir 3.310.350 kWhe e gerar energia excedente para injeção na rede durante todo o período, em média 2,4 vezes a o consumo registrado. Esse modelo, apesar de ainda apresentar valores elevados em relação aos dados de campo, teria um impacto menor no caso de investimento.

Outro cenário que deve ser levado em conta é o de aumento no custo da eletricidade no Brasil e as incertezas sobre o abastecimento. No último ano a seca e o baixo nível dos reservatórios do Sudeste/Centro-Oeste fizeram o preço da energia elétrica no mercado de 
curto-prazo bater seu valor máximo (permitido por lei) de $\mathrm{R} \$$ 822/MWhe no primeiro semestre. Isto se deve, principalmente, ao despacho de termoelétricas. Todos estes fatores juntos podem aumentar a viabilidade financeira de aproveitar energeticamente o biogás.

7.6 Redução das taxas de emissão de gases indutores do efeito estufa com a utilização de biogás para geração de eletricidade na ETE.

Uma vez mensurada e/ou estimada a vazão de biogás e o teor de metano nele presente é possível ainda calcular a quantidade de $\mathrm{CO}_{2}$ equivalente que deixaria de ser emitida para atmosfera, se o biogás fosse recuperado e transformado de maneira adequada.

A Tabela 25 apresenta as vazões volumétricas e mássicas de metano emitidos e mensurados pela ETE no período.

Tabela 25 - Vazão mensal volumétrica e mássica de metano na ETE Atuba Sul.

\begin{tabular}{ccc}
\hline Mês & Vazão volumétrica de & Vazão mássica de \\
& $\begin{array}{c}\text { metano } \\
\left(\mathrm{Nm}^{3} / \mathrm{mês}\right)\end{array}$ & $\begin{array}{c}\text { metano } \\
(\mathrm{kg} / \mathrm{mês})\end{array}$ \\
\hline $01 / 10 / 2011$ & 42.641 & 28.902 \\
$01 / 11 / 2011$ & 36.002 & 24.402 \\
$01 / 12 / 2011$ & 35.429 & 24.013 \\
$01 / 01 / 2012$ & 45.562 & 30.882 \\
$01 / 02 / 2012$ & 40.056 & 27.150 \\
$01 / 03 / 2012$ & 51.394 & 34.835 \\
$01 / 04 / 2012$ & 30.133 & 20.424 \\
$01 / 05 / 2012$ & 21.596 & 14.637 \\
$01 / 06 / 2012$ & 30.230 & 20.490 \\
$01 / 07 / 2012$ & 32.987 & 22.359 \\
$01 / 08 / 2012$ & 49.141 & 33.308 \\
$01 / 09 / 2012$ & 44.157 & 29.930 \\
\hline Total & 38.277 & 311.333 \\
\hline
\end{tabular}


Considerando a eficiência de queima do metano para aproveitamento energético igual a $95 \%$, é possível estimar a queima de $295.766 \mathrm{~kg}$ de metano no período, que equivale dizer que a ETE deixaria de emitir $295 \mathrm{tCH}_{4} /$ ano. Considerando ainda o fator de emissão do metano, que é de 25 vezes o fator de emissão do $\mathrm{CO}_{2}$ (IPCC, 2007c), poderiam ser evitadas a emissão de aproximadamente 7.394.150 $\mathrm{tCO}_{2} \mathrm{eq}$ por ano, para gerar aproximadamente 1.500.632 kWhe/ano.

Esta forma de mensuração poderia ser inserida em um sistema de monitoramento, relato e verificação (MRV) de emissões de gases do efeito estufa (GEE). O MRV é um passo importante para viabilizar políticas públicas que tenham por objetivo reduzir as emissões junto aos setores econômicos - seja por meio de um sistema de comércio de permissões, seja por tributação das emissões ou incentivos positivos, além de poder ser um apoio na orientação e avaliação de políticas já existentes e na construção de novas políticas públicas.

Um sistema de MRV bem constituído poderia definir procedimentos e diretrizes que permitem o monitoramento das emissões através da contabilização, quantificação e divulgação de informações acuradas e devidamente analisadas para auxiliar no acompanhamento do desempenho das fontes emissoras bem definidas, incluindo metas de redução.

Além disso, ainda há a parcela evitada inerente ao Sistema Interligado Nacional. Apesar da matriz energética brasileira ser considerada extremamente limpa, devido à grande contribuição das hidroelétricas, ainda seriam evitadas a emissão de 106,71 tCO tCq $_{2}$ (Tabela 26). Esse valor é equivalente a deixar de emitir 0,08 tCOeq/MWh.

Tabela 26 - Emissões evitadas através do Sistema Interligado Nacional.

\begin{tabular}{ccc}
\hline $2011-2012$ & Energia evitada (MWh) & t CO $_{2}$ eq evitado \\
\hline Out & 139,31 & 4,88 \\
Nov & 117,62 & 4,19 \\
Dez & 115,75 & 4,04 \\
Jan & 148,85 & 17,12 \\
Fev & 130,86 & 14,26 \\
Mar & 167,91 & 16,45 \\
Abr & 85,67 & 8,22 \\
Mai & 21,38 & 2,46 \\
Jun & 17,83 & 1,93
\end{tabular}




\begin{tabular}{ccc}
\hline 2011-2012 & Energia evitada (MWh) & $\mathrm{t} \mathrm{CO}_{2}$ eq evitado \\
\hline Jul & 92,85 & 7,80 \\
Ago & 160,54 & 13,33 \\
Set & 143,30 & 12,04 \\
\hline Total & & 106,71 \\
\hline
\end{tabular}

Somando ambas as contribuições, a geração de energia elétrica por meio da recuperação e da queima do biogás gerado na ETE Atuba Sul poderia evitar a emissão de $7.476,70 \mathrm{t} \mathrm{CO}_{2}$ eq durante o ano avaliado.

As emissões evitadas do SIN representam apenas 1,44\% das emissões evitadas pela queima do biogás para aproveitamento energético. Isso se deve ao fato da matriz energética brasileira ser considerada "limpa" devido à forte participação das hidrelétricas. No entanto, atribuindo esses dados a um cenário mais recente, em 2013 iniciou-se um aumento expressivo no despacho termoelétricas em função da crise hídrica no Brasil, o que deixou a matriz energética mais "suja", a projeção é de crescimento de emissões proveniente Sistema Interligado que poderão saltar de 24 milhões de toneladas, em 2012, para 33 milhões de toneladas, em 2022 (MINISTÉRIO DA CIÊNCIA E TECNOLOGIA, 2013).

Se os fatores de emissão referentes a outubro de 2013 até outubro de 2014 fossem adotados, então ter-se-iam os seguintes resultados de $\mathrm{tCO}_{2}$ equivalentes evitados para a mesma quantidade de energia elétrica gerada (Figura 48):

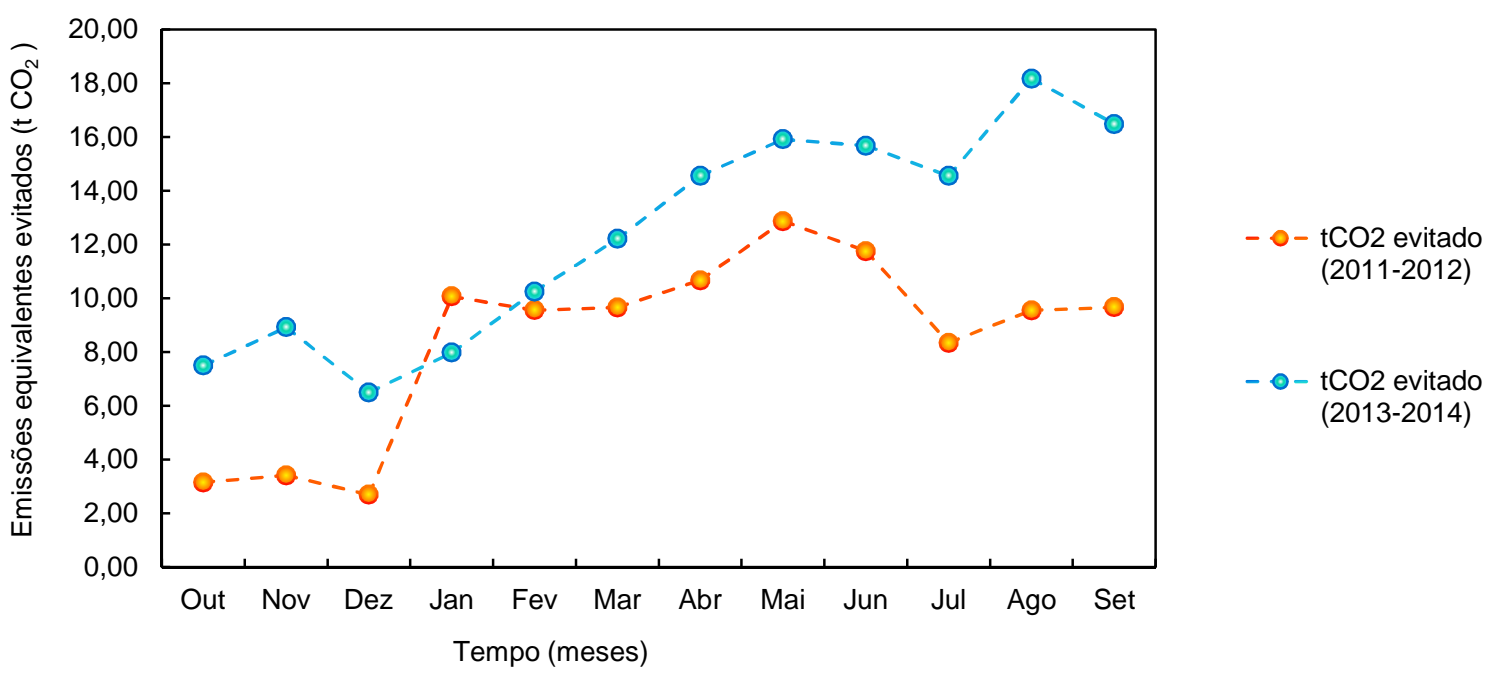

Figura 48 - Comparação das emissões evitadas ao utilizar os fatores de emissão do período de análise e referentes a outubro de 2013 até outubro de 2014 do SIN. 
Com apenas um ano de diferença entre as avaliações, as emissões evitadas do Sistema Interligado Nacional poderiam ser até 49\% maiores, isso porque entre outubro de 2013 e setembro de 2014 houve um incremento no despacho de usinas térmicas que culminaram em um aumento significativo nas emissões de $\mathrm{CO}_{2}$ eq que tendem a continuar crescendo visto que o Brasil está passando por um período de estiagem e as usinas térmicas continuarão a ser despachadas por constituírem energia firme. A Figura 49 mostra a comparação em $\mathrm{tCO}_{2}$ equivalentes entre o período analisado e com a adoção dos fatores de emissão referentes a um ano depois, onde é possível perceber a tendência de crescimento nas emissões de emissões através do Sistema Interligado Nacional.

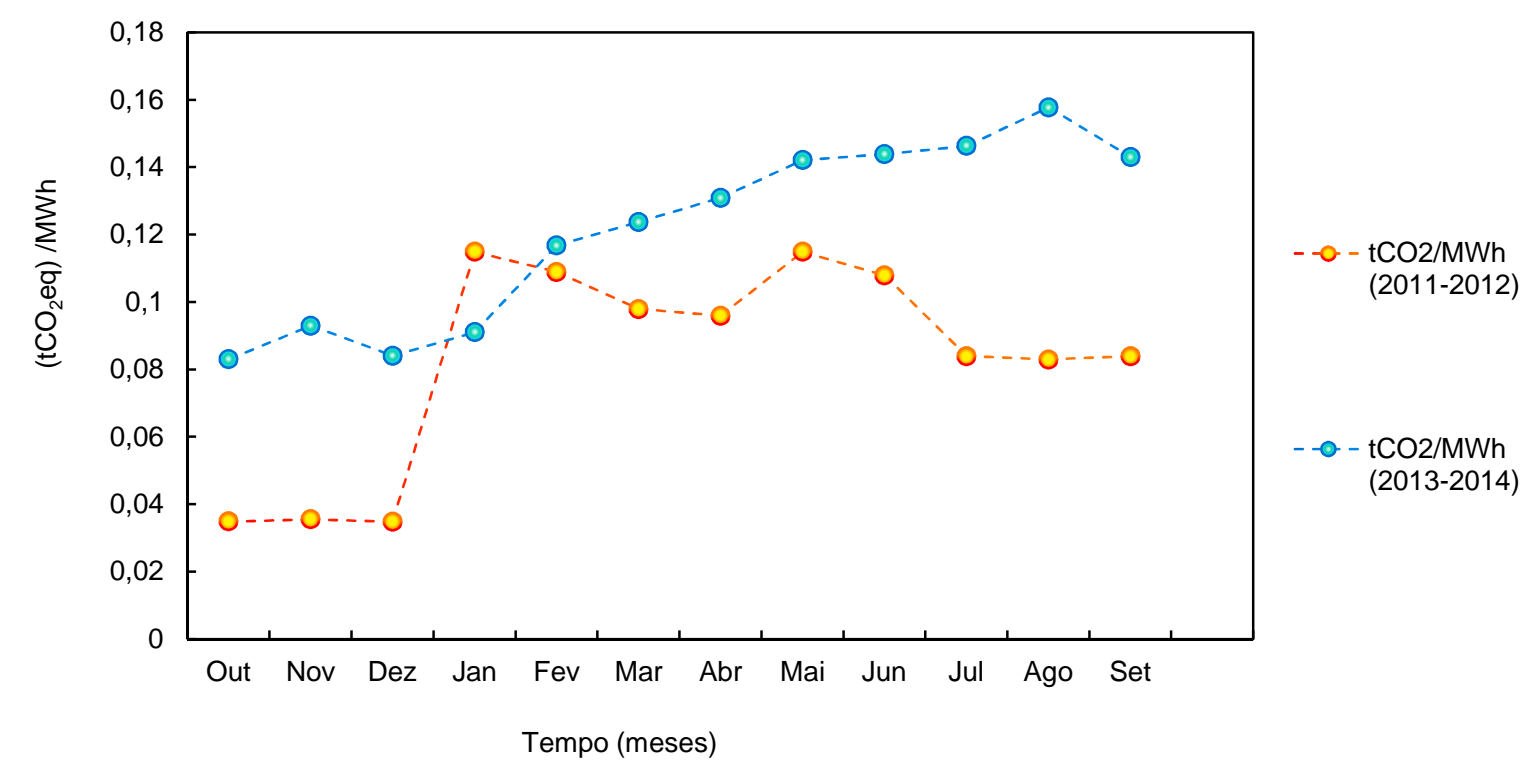

Figura 49 - Comparação em $\mathrm{tCO}_{2}$ equivalentes entre o período analisado e com a adoção dos fatores de emissão referentes a um ano depois.

Nesse sentido, ainda poderia ser viabilizado um projeto de emissões evitadas de carbono, por meio da elaboração de um documento dentro dos padrões exigidos pelo "executive board" do MDL. Este documento é chamado de PDD (Project Design Document). Além do PDD, onde todo o processo e o método de monitoramento das emissões evitadas são descritos, outros custos estão envolvidos no processo. Esses custos são chamados de custos transacionais.

Considerando que em média o valor do Certificado de Emissões Evitadas de Carbono (CEE) equivale a US\$ 10,00/t $\mathrm{CO}_{2}$ eq, valor este condizente com a maioria dos mercados internacionais e dentro da projeção encontrada na Simulação de Comércio no Brasil, seria possível certificar US\$1.067/ano, apenas das emissões evitadas no Sistema Interligado 
Nacional. Se considerar as emissões evitadas no tratamento de esgoto este valor poderia chegar a US\$73.941/ano.

Do ponto de vista ambiental, a geração de energia por meio de fontes renováveis permite a redução da queima de combustíveis fósseis e a consequente redução emissão da poluentes para a atmosfera. Considerando o biogás oriundo do tratamento de esgotos, este aproveitamento representado ainda uma melhoria no processo.

Vale ressaltar que a captação e o aproveitamento do gás metano proveniente das estações de tratamento de esgoto, com o objetivo de reduzir as emissões de GEEs, deve ser considerada como uma possibilidade para empreendimentos instalados e não usualmente como uma ação-fim. A efetiva redução de gases deste setor depende ainda da melhoria de gestão da ETE, de forma que se reduzam ao máximo as emissões fugitivas. 


\section{CONSIDERAÇÕES FINAIS}

\subsection{Conclusões}

Considerando a política energética brasileira, duas variáveis devem ser consideradas: financeiras e ambientais. Na variável financeira deve ser considerado o aumento crescente nos custos da energia do país (FIRJAN, 2014) e, nas variáveis ambientais inclui-se principalmente o aquecimento global, provocado pelas emissões de gases de efeito estufa.

Uma vez que a estimativa é de que a demanda de energia elétrica cresça de 4,3\% ao ano no período de 2013-2022 (EPE, 2013), é primordial que o crescimento do setor de energia tenha como bases os princípios de sustentabilidade, em todos os seus sentidos.

Uma das formas de se alcançar a sustentabilidade é a diversificação das fontes energéticas de forma a manter equilibrada da matriz elétrica brasileira, considerando desde a segurança energética até a sustentabilidade ambiental.

Para atender estes dois princípios é investir em aproveitamento energético de fontes disponíveis e não aproveitadas, como é o caso do biogás produzido em estações de tratamento de esgoto. O tratamento de esgotos é uma necessidade fundamental do saneamento ambiental e que ainda está em expansão, com um grande déficit no país.

Um dos seus subprodutos, o biogás, além de ser um gás indutor de efeito estufa é uma fonte energética disponível. Seu uso como fonte de geração de eletricidade pode também contribuir para a redução dos custos das ETEs, colaborando para melhorar o saneamento básico no país.

Durante o período avaliado, a análise dos parâmetros operacionais da ETE Atuba Sul mostraram que a ETE é de grande porte $(988,08 \pm 85,2) \mathrm{L} / \mathrm{s}$, em termos de carga orgânica afluente o esgoto é predominantemente doméstico. Além disso, a DQO e a DBO recebidas foram bastante variáveis ao longo do tempo, a DQO afluente média foi de $(449,7 \pm 143,2)$ mg/L variando de 138 a $905 \mathrm{mg} / \mathrm{L}$. A DBOafluente média foi de $(230,6 \pm 72,9) \mathrm{mg} / \mathrm{L}$ e sua variação foi de 50 a $440 \mathrm{mg} / \mathrm{l}$. Enquanto a eficiência do tratamento nos reatores UASB mostraram uma variação com desvio padrão bem menor, de $(73 \pm 8) \%$ e $(61 \pm 11) \%$ respectivamente. 
Os resultados da quantificação em tempo real das taxas de produção de biogás e de metano na ETE Atuba Sul durante todo o período avaliado demonstrou que a vazão do biogás seguiu o mesmo comportamento temporal variável. Além disso, esse comportamento foi periódico e não estacionário, com períodos de um dia e vazões máximas entre 0 e 2 horas e as vazões mínimas entre 12 e 14 horas. A vazão média de biogás foi igual a $(84,30 \pm 26,64)$ $\mathrm{Nm}^{3} / \mathrm{h}$, com teor de metano de $(63,03 \pm 17,89) \% \mathrm{v} / \mathrm{v}$.

A amplitude de variação de vazão de biogás foi grande, apresentando máxima de $136,52 \mathrm{Nm}^{3} / \mathrm{h}$ e mínima vazão igual a $28,17 \mathrm{Nm}^{3} / \mathrm{h}$. No entanto, nos eventos de chuva foi possível perceber uma variação ainda maior principalmente conforme as chuvas aumentaram de intensidade. Apesar de estes efeitos serem aparentemente pequenos quando comparados à média de vazão anual, que levaria a uma redução média de 3,44\% ao ano, pontualmente eles se mostram muito significativos, podendo reduzir a vazão média de biogás em 23,2\% nos dias em que há eventos de chuva, principalmente na hipótese de se aproveitar energeticamente o biogás, pois manifestam a necessidade da ETE se manter ligada à rede de distribuição de energia elétrica para garantir o fornecimento da demanda de energia.

Apesar de estes efeitos serem aparentemente pequenos quando comparados à média de vazão anual, pontualmente eles se mostram muito significativos, principalmente na hipótese de se aproveitar energeticamente o biogás, pois manifestam a necessidade da ETE se manter ligada à rede de distribuição de energia elétrica para garantir o fornecimento da demanda de energia e portanto, sugere-se considerar a influência dos eventos de chuvas na concepção de eventuais projetos de aproveitamento energético de biogás.

Para reduzir esses efeitos, é preciso investir em redes de captação de esgotos mais integras e menos extensas, com menor índice de infiltração. No entanto, esse não é o único fator que influência a variação de vazão de biogás, outros fatores também devem ser identificados e, se possível, controlados.

Este trabalho demonstrou ainda que a vazão de biogás e a quantidade de energia estimada pelos métodos existentes - associadas com a recuperação do biogás gerado na ETE Atuba Sul - são, em média, maiores que aquela realmente disponível para uso. Além disso, dependendo do método utilizado tal quantidade pode ser até 10 vezes maior que aquela verificada a partir de medições de campo.

Isso acontece porque os métodos propostos pelo IPCC (2006), pela CETESB (2006), pelo UNFCCC (2013) e por Chernicharo (1997), não consideram as perdas de metano, assim 
como algumas importantes rotas de conversão de DQO durante o tratamento anaeróbio do esgoto.

Como o modelo proposto por Lobato (2011) contempla as quantidades de metano dissolvidas no meio líquido, assim como as perdas na forma de gases residuais e as perdas relacionadas com a redução de sulfato, ele expressa de forma mais verossímil os fenômenos físicos, químicos e biológicos inerentes aos reatores UASB, fazendo com que os resultados obtidos a partir de sua aplicação apresentem menor desvio em relação aos valores mensurados.

Além disso, verificou-se que as incertezas inerentes às estimativas não podem ser negligenciadas, visto que elas representaram pelos menos $27 \%$ dos valores médios.

Dessa forma, as mudanças das condições operacionais da ETE e as variações das propriedades físicas e químicas do esgoto que entra nos reatores UASB fazem com que as taxas de produção de biogás e de recuperação de energia oscilem expressivamente, em relação aos valores médios, ao longo de um ano.

Logo, os resultados apresentados neste trabalho indicam que a escolha do método de estimativa da quantidade de energia química disponibilizada por reatores UASB na forma de biogás pode influenciar significativamente no dimensionamento e na viabilidade financeira e econômica de projetos que vislumbrem a geração de energia renovável em ETEs. Por isso, recomenda-se que as tomadas de decisão inerentes ao tema sejam baseadas em resultados de medições e que, se porventura tal prática não for exequível, então que o método proposto por Lobato (2011) seja utilizado. Além disso, sugere-se que a análise de incertezas também seja realizada com o intuito de quantificar as limitações e os riscos inerentes aos projetos.

Analisando os resultados reportados por Lobato (2011), percebemos que a ETE Atuba Sul produziu menos biogás que o previsto no modelo, isso indica que a ETE pode estar com problemas em sua operação ou estruturais que aumentam as perdas e diminuem a disponibilidade de biogás. Isso pode ser explicado entre outros fatores pelo fato de se tratar de uma ETE antiga, e com uma ampla rede de atendimento, que permite infiltrações. Além disso, o sistema não é estanque e, portanto, acredita-se que existe perdas consideráveis de gás por tampões mal selados, fissuras e aberturas no concreto, assim como na linha de gás (entre conexões de dispositivos, como por exemplo válvulas e tubulações), o que pode ter sido a causa de menos de $42 \%$ do metano ter sido guiado para aproveitamento.

O aproveitamento energético do biogás gerado na ETE Atuba Sul chega próximo da autossuficiência, ou seja, o biogás supre quase toda a necessidade energética da ETE, de tal 
forma que em alguns meses pode inclusive haver excedente de energia e em outros pode faltar. A potência elétrica máxima calculada foi $233 \mathrm{~kW}$. Nesse caso, seria possível utilizar as novas diretrizes reportadas na Resolução Normativa $n^{\circ}$ 482/2012 da ANEEL, que classifica esta potência como possível minigeração distribuída, o que permite a compensação de energia elétrica por meio de créditos gerados, e facilitando o acesso à rede, visto que os antigos contratos com as concessionária tornava difícil o aproveitamento devido à necessidade de garantia de fornecimento contínuo e qualidade de energia, o que tornava a energia ainda mais cara. Mediante adesão ao sistema de compensação a ETE poderia inclusive gerar créditos para a conta de energia elétrica de outra Estação, levando a economia financeira para a ETE e economia energética para a matriz nacional. No entanto, ainda há barreiras na questão da tributação, e é muito importante que este tema seja mais debatido para reduzir os impostos incidentes, de forma que este insumo possa, inclusive, ajudar na expansão do saneamento ambiental.

No entanto, sabendo que há grande variação de vazão de biogás ao longo do ano, e que essa variação possui frequência de um dia com máximas e mínimas bem definidas, é importante que a ETE mantenha ainda um gasômetro, para que possa regularizar a vazão de biogás durante o dia.

Outro ponto importante é a questão das emissões de gases de efeito estufa, um grande problema ambiental enfrentado hoje pelo mundo. As ETEs operadas com reatores UASB são grandes emissoras de metano, e a sua recuperação é fundamental para reduzir essas emissões, que no presente trabalho poderia ser de 7.476,70 $\mathrm{t} \mathrm{CO}_{2}$ eq. Assim a queima do metano para gerar energia evita estas emissões no setor de saneamento e ainda permitem evitar emissões do Sistema Interligado Nacional mitigando o efeito estufa e evitando custos ambientais correspondentes às fontes convencionais. E ainda podendo gerar benefícios financeiros de até US\$ 73.941/ano com a venda de certificado de emissões evitadas.

Verificou-se ainda que a produção de biogás está ligada à eficiência dos reatores anaeróbios. Por isso, problemas no tratamento preliminar e nos reatores anaeróbios podem reduzir as eficiências de tratamento levando também à diminuição da produção de biogás, e que em períodos de chuva, devido à alta dissolução do afluente e infiltração na rede coletora, a produção de biogás pode decair drasticamente. 


\subsection{Trabalhos futuros}

Sugere-se como trabalhos futuros estabelecer critérios para o dimensionamento de plantas de aproveitamento energético de biogás oriundos de ETEs, pautando-se na interpretação dos resultados das medições de biogás realizadas em campo.

Além disso, o biogás possui diversas aplicações de caráter energético e não precisa ficar restrito à aplicação como combustível em um motor de combustão interna a gás, que movimenta um gerador de energia elétrica. Mesmo dentro de uma ETE ele ainda pode ser direcionado para secagem e higienização de lodo que, atualmente, é feita de forma ineficiente, o que também poderia ser estudado no dimensionamento de uma planta de aproveito energético térmico e elétrico (cogeração).

Por questões de operação, manutenção, operação e custos, é recomendado realizar estudos de pesquisa para a dissipação mecânica do metano que fica preso na fase líquida do efluente. Esses estudos podem trazer maior viabilidade financeira para projetos de aproveitamento energético em ETEs e aumentarem o interesse de investimentos no setor.

Poder-se-ia estudar, ainda, formas de aumentar a produção de biogás disponível na ETE Atuba Sul. Para isso, seriam necessárias várias alterações operacionais na ETE, entre eles:

Um tratamento preliminar eficiente é condição essencial para um alto desempenho dos reatores anaeróbios. A ineficiência do tratamento preliminar leva ao acúmulo de resíduos nos reatores anaeróbios, tendo-se como consequência a diminuição do volume útil dos reatores, o entupimento dos distribuidores, o adensamento do leito de lodo, a contaminação da escuma e do lodo, e, consequentemente, uma menor disponibilidade de biogás.

Realizar o monitoramento adequado dos reatores anaeróbios que, atualmente, é incompleto (não há controle da altura da manta do lodo, hidráulica, produção de lodo, vazão de gás, etc.).

Idealmente, é recomendável a retirada pré-programada e continuada do lodo em excesso (por exemplo, quinzenalmente ou mensalmente) para que o reator opere ciclicamente da forma mais estável possível. A frequência do descarte pré-programado deve ser estipulada de acordo com a logística de operação da próxima etapa de tratamento do lodo (centrífuga ou leito de secagem). Descartes não programados devem ser realizados excepcionalmente em casos em que concentrações muito altas impeçam uma operação adequada dos reatores (p.ex. 
adensamento muito intenso do leito do lodo, observado pela análise de perfil de sólidos, ou perda de sólidos no efluente, observado por valores de sólidos sedimentáveis maiores que 0,2 $\mathrm{ml} / \mathrm{l})$.

A quantidade de lodo a ser retirada deve ser minimizada com o objetivo de maximizar a idade média do lodo (maior produção de gás e maior mineralização do lodo). Na prática, o descarte deve ser feito de acordo com as concentrações de lodo dentro do compartimento de digestão. Os reatores devem ser operados com as maiores concentrações possíveis para maximizar a idade do lodo, sem que sólidos sejam perdidos ou o lodo muito adensado.

É de vital importância que os tampões dos reatores anaeróbios sejam totalmente estanques. Caso contrário, a pressão da câmara de gás pode ser reduzida pela perda de gás, possibilitando assim a entrada de ar. A entrada de ar deve ser evitada devido à formação de misturas explosivas (metano/oxigênio) e problemas de corrosão do concreto pela formação de ácido sulfúrico biogênico. Além disso, o gás perdido contribui para a diminuição do aproveitamento energético (em ETEs em que este é aproveitado) e o aumento de odor. A saída de gás pode ser também perigosa pela emissão de gás sulfídrico, que é tóxico.

Outro ponto importante quando se deseja aproveitar energeticamente o biogás de ETEs é o separador trifásico, existem diversos modelos, sendo os mais usuais feitos em concreto e lona plástica, no entanto, não há estudos sobre a impermeabilidade da lona plástica em relação ao metano, além disso, durante a operação estas lonas podem desgastar e apresentar rasgos, que permitem a fuga do metano concentrado no reator, por isso sugere-se a utilização placas de plástico duro, como por exemplo, PP ou PE que devem ser fixadas juntamente com uma película flexível para vedação.

A retirada de escuma é outro ponto importante que deve ser trabalhado, o acúmulo de escuma pode selar a câmara de gás prejudicando sua vazão, além disso, durante a limpeza também há perda de gás, e isso deve ser controlado;

Além disso, devido às características corrosivas do biogás é importante escolher adequadamente o material a ser utilizado de modo que seja suficientemente resistente.

Conclui-se que com o planejamento adequado, é possível haver interação entre saneamento ambiental de qualidade e geração de energia de forma sustentável, isso porque a qualidade das instalações da estação e a eficiência do tratamento estão diretamente relacionados à quantidade de energia produzida e, portanto, pode ser uma relação que agrega benefícios para ambos os setores. 


\section{REFERÊNCIAS}

ANDRADE, J. C. de . Química Analítica Básica: Os conceitos acido-base e a escala de pH. Chemkeys - Liberdade para aprender. 2010. Disponível em http://www.portalmedquimica.com.br/arquivos/articleI-Acidez.php.pdf. Acesso em 25 de setembro de 2014.

ANEEL - AGÊNCIA NACIONAL DE ENERGIA ELÉTRICA. Guia do cogerador de energia elétrica. Brasília: Distrito Federal, 1998. (Série Estudos e Informações Hidrológicas e Energéticas, 5). CD ROM, 1998.

2008. Resolução Autorizativa $\mathbf{N}^{\circ}$ 1.482, de 29 de julho de 2008 - In: Resoluções, 2008. Disponível em: http://www.aneel.gov.br. Acesso em: 09/07/2013.

2009. Resolução Autorizativa $\mathbf{N}^{\circ} \mathbf{1 . 9 0 0}$, de 05 de maio de 2009 - In: Resoluções, 2009. Disponível em: http://www.aneel.gov.br. Acesso em: 09/07/2013.

2010. Resolução Normativa $\mathbf{N}^{\circ}$ 414, de 9 de setembro de 2010 - In: Resoluções, 2010. Disponível em: http://www.aneel.gov.br. Acesso em: 09/07/2013.

2011. Resolução Homologatória $\mathbf{N}^{\circ}$ 1158, de 21 de junho de 2011 - In: Resoluções, 2010. Disponível em: http://www.aneel.gov.br. Acesso em: 09/07/2013.

2012a. Resolução Normativa $\mathbf{N}^{\circ}$ 482, de 17 de abril de 2012 - In: Resoluções, 2012. Disponível em: http://www.aneel.gov.br. Acesso em: 09/07/2013.

2012b. Resolução Homologatória $\mathbf{N}^{\circ}$ 1.296, de 19 de junho de 2012 - In: Resoluções, 2012. Disponível em: http://www.aneel.gov.br. Acesso em: 09/07/2013.

2012c. Procedimentos de Distribuição de Energia Elétrica no Sistema Elétrico Nacional - PRODIST. Módulo 3. Revisão 5, 2012. Disponível em http://www.aneel.gov.br/visualizar_texto.cfm?idtxt=1867. Acesso em: 09/07/2013.

2014a. Chamada Estratégica No 014/2012, Projeto Estratégico: “Arranjos Técnicos e Comerciais para Inserção da Geração de Energia Elétrica a Partir de Biogás Oriundo de Resíduos e Efluentes Líquidos na Matriz Energética Brasileira”. Brasília, julho de 2012. Disponível em: http://www.aneel.gov.br/arquivos/PDF/PeD-2012Chamada\%20PE\%2014_23-07-12.pdf. Acesso em: 09/07/2013. 
2014b. Micro e minigeração distribuída: sistema de compensação de energia elétrica, Cadernos Temáticos ANEEL, disponível em http://www.aneel.gov.br/biblioteca/downloads/livros/caderno-tematicomicroeminigeracao.pdf

2014.

2014c. Procedimentos de Regulação Tarifária - Proret. Módulo 7. Revisão 1.4, http://www.aneel.gov.br/arquivos/PDF/PRORET\%20Subm\%C3\%B3dulo\%207\%201\%204\% C2\%AA\%20revis\%C3\%A3o.pdf. Acesso em: 09/07/2013.

AGRAWAL, L. K.; HARADA, H.; OKUI, H. Treatment of Dilute Wastewater in a UASB Reactor at a Moderate Temperature: Performance Aspects. Journal of Fermentation and Bioengineering, v. 83, n. 2, p. 179-184, 1997.

ALVES, João Wagner Silva. Diagnóstico Técnico Institucional da Recuperação e Uso Energético do Biogás Gerado pela Digestão Anaeróbica de Resíduos. 2000. 142 f. Dissertação (Mestrado em Ciências) - Programa de Pós-Graduação em Energia da Universidade de São Paulo, São Paulo, 2000.

ALVES, J. W. S; Manso, S. M. Inventário Nacional de emissões de metano pelo manejo de resíduos. São Paulo: CETESB, 1998.

ASSOCIAÇÃO ALEMÃ DE GESTÃO HÍDRICA, EFLUENTES E RESÍDUOS. GUIA TÉCNICO DWA-M 363: Origem, Tratamento e Utilização do Biogás. Alemanha, 2010.

BARBOSA, V.L.; STUETZ, R.M. Treatment of hydrogen sulfide in biofuels. In: LENS, P., WESTERMANN, P.; HABERBAUER, M.; MORENO, A. (Ed.). Biofuels for fuel cells: renewable energy from biomass fermentation. London: IWA Publishing, 524 p. 2005.

BDMEP - Banco de Dados Meteorológicos para Ensino e Pesquisa. Disponível em <htp:/www.inmet.gov.br/projetos/rede/pesquisa/>. Aceso em Setembro de 2014.

BORGES, E. S. M. et al. Tratamento Térmico de Lodo Anaeróbio com Utilização do Biogás Gerado em Reatores UASB: Avaliação da Autossustentabilidade do Sistema e do Efeito sobre a Higienização e a Desidratação do Lodo. Engenharia Sanitária e Ambiental, v. 14, 337346, 2009. 
BRASIL, G. H; SOUZA JUNIOR, P. A.; CARVALHO JUNIOR; J. A. Inventário corporativos de gases de efeito estufa: métodos e usos, $S \& G$ Revista Eletrônica, 12p, 2008.

BUSTAMANTE, Tania Giovanna Caycho. Impactos da chuva na ocorrência de deslizamento de terra e inundações no Estado de São Paulo. 2010. 106 f. Dissertação (Mestrado em Meteorologia) - Instituto Nacional de Pesquisas Espaciais, INPE, São José dos Campos, 2010.

CAKIR, F.Y.; STENSTROM, M.K. Greenhouse gas production: A comparison between aerobic and anaerobic wastewater treatment technology. Water Research, v. 39, p. 41974203. 2005.

CARVALHO A. L. de, et al. Distribuição mensal e anual da ocorrência de dias secos e chuvosos na região de Rio Largo Alagoas. In: XVI Congresso Brasileiro de Meteorologia, Belém, 2010. Disponível em: http://www.cbmet2010.com/anais/artigos/245_76960.pdf. Acesso em: 26 de julho de 2012.

CCE - CENTRO PARA CONSERVAÇÃO E ENERGIA. Guia Técnico de Biogás. Amadora - Portugal, 2000. $117 \mathrm{p}$

CENBIO - Centro Nacional de Referência em Biomassa. Projeto Programa de Uso Racional de Energia e Fontes Alternativas - PUREFA. Relatório de Acompanhamento. São Paulo, 2003.

2004. Projeto Instalação e Testes de uma Unidade de Demonstração de Geração de Energia Elétrica a partir de Biogás de Tratamento de Esgoto - ENERG-BIOG. Relatório de Atividades. Relatório Técnico. São Paulo, 2004.

2005. Projeto Programa de Uso Racional de Energia e Fontes Alternativas PUREFA. Relatório Técnico Final. São Paulo, 2005.

CETESB - COMPANHIA DE TECNOLOGIA DE SANEAMENTO AMBIENTAL. Manual do Usuário do software Biogás: Geração e uso energético - Efluentes, versão 1.0 / CETESB, Departamento Ambiental, Ministério Brasileiro de Ciência e Tecnologia. São Paulo, 2006. Disponível em http://www.cetesb.sp.gov.br/mudancas-climaticas/biogas/Softwares/16Softwares.

CHERNICHARO, C. A. L. Princípios do tratamento biológico de águas residuárias; reatores anaeróbio. Belo Horizonte - MG: Departamento de Engenharia Sanitária e Ambiental, UFMG, ed. 1, v. 5, 1997. 
CHERNICHARO, C. A. L. Reatores anaeróbios: Princípios do tratamento biológico de águas residuárias, v.5. Belo Horizonte - MG: Departamento de Engenharia Sanitária e Ambiental. UFMG. $2^{\mathrm{a}}$ ed., 2007. 380 p.

CHERNICHARO, C.A.L.; STUETZ, R.M. Energy Recovery from Biogas in Anaerobic Wastewater Treatment Plants. 2008. In: CHERNICHARO, C.A.L. Limitações e Possíveis Melhorias Futuras no Projeto, na Construção e na Operação de Reatores UASB Tratando Esgotos Domésticos. Relatório final de atividades referente a pós-doutorado. Belo Horizonte: Departamento de Engenharia Sanitária e Ambiental da UFMG, 2009.

COELHO, S.T. et al. Estado da arte do biogás. Relatório de Acompanhamento. CENBIO Centro Nacional de Referência em Biomassa. São Paulo, 2001.

COELHO, S.T. et al. A Conversão da Fonte Renovável Biogás em Energia. In: V Congresso Brasileiro de Planejamento Energético, Brasília, 2006. Disponível em: http://cenbio.iee.usp.br/download/projetos/8_energ-biog.pdf. Acesso em 15 de novembro de 2014.

CONAMA - CONSELHO NACIONAL DE MEIO AMBIENTE. Resolução CONAMA N $^{\circ}$ 357, de 17 de março de 2005 - In: Resoluções, 2005. Disponível em: http://www.mma.gov.br Acesso em: 09/07/2013

2006. Resolução CONAMA n ${ }^{\circ}$ 375, de 29 de Agosto de 2006 - In: Resoluções, 2006. Disponível em: http://www.mma.gov.br Acesso em: 09/07/2013

2009. Resolução CONAMA n 410 de 04 de maio de 2009, de - In: Resoluções, 2009. Disponível em: http://www.mma.gov.br Acesso em: 09/07/2013

2011. Resolução CONAMA $\mathbf{N}^{\circ} 430$ de 13 de maio de 2011, de - In: Resoluções, 2011. Disponível em: http://www.mma.gov.br Acesso em: 09/07/2013

COSTA, David Freire da . Geração de Energia Elétrica a Partir do Biogás de Tratamento de Esgoto. 2006. 194 f. Dissertação (Mestrado em Ciências) - Programa de Pós-Graduação em Energia da Universidade de São Paulo, São Paulo, 2006.

EL-FADEL, M.; MASSOUD, M. Methane Emissions from Wastewater Management. Environmental Pollution, v. 114, p. 177-185. 2001. 
EPE - Empresa de Pesquisa Energética. Plano Decenal de Expansão de Energia 2022. Brasília. MME/EPE, 2013. Disponível em: http://www.epe.gov.br/pdee/forms/epeestudo.aspx. Ultimo acesso em: 09/12/2014

EUROPEAN COMMISSION. Environmental pressure indicators for the EU, Eurostat, p. 1985-98; Office for official publications of the European Communities. Luxembourg. 2001.

FIRJAN - FEDERAÇÃO DAS INDÚSTRIAS DO ESTADO DO RIO DE JANEIRO. Perspectivas do Custo da Energia Elétrica para Indústria no Brasil em 2014 E 2015. Nota Técnica $\mathrm{n}^{\circ} 1$ - maio de 2014. Rio de Janeiro. 2014. Disponível em http://www.firjan.org.br/lumis/portal/file/fileDownload.jsp?fileId=2C908CEC45F062B60146 1B962A1352C5. Último acesso em 18/01/2015.

FORESTI, E. Fundamentos do processo de digestão anaeróbia. In: Tallery Seminario Latino Americano Tratamiento Anaerobio De Aguas Residuales, 1994, Montevidéu, Uruguai. Anais. p. $97-110$.

FORESTI, E. et al. Fundamentos do Tratamento Anaeróbio. In: Tratamento de Esgotos Sanitários por Processo Anaeróbio e Disposição Controlada no Solo. Rio de Janeiro: PROSAB, ABES. Cap.2, pp. 29-52, 1999.

FRANCO, Pedro Luís Prado. Análise da potencialidade do reúso indireto potável: estudo de caso da ETE Atuba Sul, Região Metropolitana de Curitiba. 2010. 238 f. Dissertação (Mestrado Profissional) - Universidade Federal do Paraná, Setor de Tecnologia, Programa de Mestrado Profissional em Meio Ambiente Urbano e Industrial Curitiba, 2010.

FRANÇA JR. Antonio Tavares de . Análise do aproveitamento energético do biogás produzido numa estação de tratamento de esgoto. 2008. 148 f. Dissertação (Mestrado em Engenharia Mecânica) - Faculdade de Engenharia de Ilha Solteira, UNESP. Ilha Solteira, 2008 .

GAIO, M. M. Experiência da COPASA MG no aproveitamento energético do biogás na ETE Arrudas. In IV Seminário Internacional de Engenharia de Saúde Pública, 2013.

GLÓRIA, Roberto Meireles. Estudo dos processos de formação, acumulação, emissão e oxidação de sulfeto de hidrogênio em reatores UASB tratando esgotos domésticos. 2009. 53p. 2009. Dissertação (Mestrado em Saneamento) - Escola de Engenharia, Universidade Federal de Minas Gerais, Belo Horizonte, 2009. 
GOOGLE EARTH - MAPAS. http://mapas.google.com. Ultimo acesso em 25/09/2014.

HENSON, R. Alterações Climáticas - Sintomas, Ciência, Soluções. Civilização Editores, Porto, 2009. 384p.

HOLM-NIELSEN, J.B.; AL SEADI, T.; OLESKOWICZ-POPIEL, P. The future of anaerobic digestion and biogas utilization. Bioresource Technology, v. 100, p. 5478-5484. 2009.

IEA - INTERNATIONAL ENERGY AGENCY. Biogas Flares: State of the Art and Market Review. Topic report of the IEA Bioenergy Agreement Task 24 - Biological conversion of municipal solid waste: IEA Bioenergy, 12 p. 2000.

IMHOFF, K. R.; IMHOFF, K. Manual de tratamento de águas residuárias. Editora Edgard Blucher. São Paulo, 1996.

IDDRI; SDSN. INSTITUTE FOR SUSTAINABLE DEVELOPRMENT AND INTERNATIONAL RELATIONS; SUSTAINABLE DEVELOPMENT SOLUTIONS NETWORL. Pathways to Deep Decarbonization - 2014 Report. 2014. Disponível em http://unsdsn.org/what-we-do/deep-decarbonization-pathways/. Último acesso em 02/02/2015.

IPCC - INTERGOVERNMENTAL PANEL ON CLIMATE CHANGE. Guidelines for National Greenhouse Gas Inventories, Greenhouse Gas Inventory Reference Manual. Waste. V. 1 Reporting Instructions. 1996.

2006. Waste. In: Guidelines for National Greenhouse Gas Inventories. Prepared by the National Greenhouse Gas Inventories Programme. EGGLESTON, H. S.; BUENDIA, L.; MIWA, K.; NGARA, T.; TANABE, K. (eds.). V. 5, Chapter 6 , IGES, Japan, 2006.

2007a. Climate Change 2007: The Physical Science Basis. Contribution of Working Group I to the Fourth Assessment Report of the Intergovernmental Panel on Climate Change. SOLOMON, S.; QIN, D.; MANNING, M.; CHEN, Z.; MARQUIS, M.; K.B.M TIGNOR and MILLER, H.L. (Eds.). Cambridge University Press. Cambridge, United Kingdom and New York, NY, USA, 996 p. 2007a

2007b. Climate Change 2007: Mitigation of Climate Change. Contribution of Working Groups III to the Fourth Assessment Report of the Intergovernmental Panel on Climate Change. METZ, B.; DAVIDSON, O. R.; BOSCH, P. R.; DAVE, R.; MEYER, L. A. (Eds.). Cambridge University Press, Cambridge, United Kingdom and New York, NY, USA. 2007. 
2007c. Climate Change 2007: Synthesis Report. Contribution of Working Groups I, II and III to the Fourth Assessment Report of the Intergovernmental Panel on Climate Change. CORE WRITING TEAM; PACHAURI, R.K and REISINGER, A. (Eds.). IPCC, Geneva, Switzerland, 104 p. 2007c.

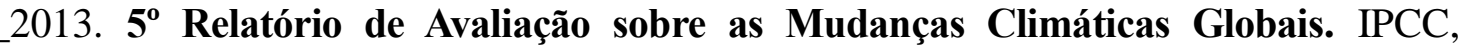
Stockholm, Suécia, 2013.

2014. Climate Change 2014: Synthesis Report. Contribution of Working Groups I, II and III to the Fifth Assessment Report of the Intergovernmental Panel on Climate Change. CORE WRITING TEAM; PACHAURI, R.K and MEYER, L. A. (Eds.). IPCC, Geneva, Switzerland, 101 p. 2014.

KHALILI, Amyra El. O que são Créditos de Carbono? Revista Eco 21, Ano XII, No 74, Janeiro 2003.

LAUTMAN, L. Reliability of Natural Gas Cogeneration Systems. New York: Gas Research Institute, 1993. 186 p.

LETTINGA, G. et al. Anaerobic treatment of raw domestic sewage at ambient temperatures using a granular bed UASB reactor. Biotecnology and bioengineering. 25: 1701-23, 1983.

LOBATO, L. C. S.; CHERNICHARO, C. A. L; SOUZA, C. L. Estimates of methane loss and energy recovery potential in anaerobic reactors treating domestic wastewater . Water Science \& Technology. V. 66, n.12 p. 2745-2753, 2012.

LOBATO, Lívia Cristina da Silva. Aproveitamento energético de biogás gerado em reatores UASB tratando esgoto doméstico. 2011. 184 f. Tese (Doutorado em Saneamento, Meio Ambiente e Recursos Hídricos). Programa de Pós-Graduação em Saneamento, Meio Ambiente e Recursos Hídricos da Universidade Federal de Minas Gerais. Belo Horizonte MG, 2011.

LUDUVICE, M. Processos de estabilização de lodos. In: Lodos de Esgotos - Tratamento e Disposição Final. Rio de Janeiro: ABES, 2001. 484p.

MINISTÉRIO DAS CIDADES. Diagnóstico dos Serviços de Água e Esgoto - 2013. Brasília, 2014.

Disponível em 
http://www.snis.gov.br/PaginaCarrega.php?EWRErterterTERTer=105. Último acesso: 06/04/2015.

2013. Plano Nacional de Saneamento Básico - PLANSAB - Brasília, 2013. Disponível em: http:// http://www.cidades.gov.br/mwginternal/de5fs23hu73ds/progress?id=3FvVwSoxWSqMf_zqG7EDRDpm4kd1c3bUjXPLoOMEcE. Acesso em: 09/07/2014

MINISTÉRIO DA CIÊNCIA E TECNOLOGIA. Inventário de emissões e remoções antrópicas de gases de efeito estufa não controlados pelo Protocolo de Montreal: Segunda Comunicação Nacional do Brasil à Convenção-Quadro das Nações Unidas sobre Mudança de Clima. Brasília: 518 p. 2010.

MINISTÉRIO DA CIÊNCIA E TECNOLOGIA. Fatores de Emissão de $\mathbf{C O}_{2}$ para utilizações que necessitam do fator médio de emissão do Sistema Interligado Nacional do Brasil, como, por exemplo, inventários corporativos. Brasília. 2013. Disponível em http://www.mct.gov.br/index.php/content/view/74694.html. Último acesso: 20/05/2014.

MINISTÉRIO DE MINAS E ENERGIA. Plano Nacional de Eficiência Energética: Premissas e Diretrizes Básicas, 2009. Disponível em: http://www.mma.gov.br Acesso em: 09/07/2013

NOAA - NATIONAL OCEANIC AND ATMOSPHERIC ADMINISTRATION. Global Temperature and Carbon Dioxide. Imagem, color. Disponível em: http://www1.ncdc.noaa.gov/pub/data/cmb/images/indicators/global-temp-and-co2-1880-2009300.gif

NOYOLA, A.; CAPDEVILLE, B.; ROQUES, H. Anaerobic treatment of domestic sewage with a rotating stationary fixed-film reactor. Water Research, v. 22, n. 12, p. 1585-1592. 1988.

NOYOLA, A.; MORGAN-SAGASTUME, J. M.; LÓPEZ-HERNANDEZ, J. E. Treatment of biogas produces in anaerobic reactors for domestic waste water: odor control and energy/resource recovery. Reviews in Environmental Science and Bio/Technology, v. 5, p. 33-114, 2006.

OLIVA, Lívia Cristina Holmo Villela. Tratamento de esgotos sanitários com reator anaeróbio de manta de lodo (UASB). Protótipo: desempenho e respostas dinâmicas às sobrecargas hidráulicas. 1997. Tese (Doutorado em Hidráulica e Saneamento). Escola de Engenharia de São Carlos, USP. (1997) 
ODDONE, D. C. COGERAÇÃO: UMA ALTERNATIVA PARA PRODUÇÃo DE ELETRICIDADE. 2001. 82p. Dissertação (Mestrado em Ciências), Programa de PósGraduação em Energia da Universidade de São Paulo. São Paulo, p. 14. 2001.

ORLICH, J. Methane emissions from landfills sites and wastewater lagoons. International Workshop on Methane Emissions from Natural Gas Systems, Coal Mining and Waste Management Systems. Japan Envioronment Agency and the USEPA, pp. 465-471. 1990 apud EL-FADEL, M.; MASSOUD, M. Methane emissions from wastewater management. Environmental Pollution, v. 114, p. 177-185. 2001

PECORA, Vanessa, Implementação de uma unidade Demonstrativa de Geração de Energia Elétrica a partir do Biogás de Tratamento do Esgoto Residencial da USP: estudo de caso. 2006. 152 p. Dissertação (Mestrado em Ciências), Programa de PósGraduação em Energia da Universidade de São Paulo. São Paulo, 2006.

PERRY, R.H., GREEN, D.W. Perry's chemical engineers' handbook. 7 ed. New York: McGraw-Hill. 1997.

POSSETTI, G. R. C. et al. Medições em tempo real do biogás produzido em reatores uasb alimentados com esgoto doméstico. In: Anais do $27^{\circ}$ Congresso Brasileiro de Engenharia Sanitária e Ambiental, 2013.

PROGRAMA BRASILEIRO GHG PROTOCOL, Especificações do Programa Brasileiro GHG Protocol: Contabilização, Quantificação e Publicação de Inventários Corporativos de Emissões de Gases de Efeito Estufa, 2a edição, 2010. Disponível em: $<$ http://www.ghgprotocolbrasil.com.br/index.php?page=Conteudo\&id=5>. Último acesso em 28 de setembro de 2013.

ROSS, C.C., DRAKE, T.J., The handbook of biogas utilization, U.S. Department of Energy Southeastern Regional Biomass Energy Program Tennessee Valley Authority, Muscle Shoals, Alabama, Second Edition, 1996.

SANEPAR - COMPANHIA DE SANEAMENTO DO PARANÁ. Inventário 2013 Companhia de Saneamento do Paraná. Disponível em https://sistema.registropublicodeemissoes.com.br/index.php?r=inventory/public _pdf\&cid=ND $\mathrm{c}=\& \mathrm{t}=$ Simple $\& \mathrm{y}=\mathrm{MjAxMw}==$. Último acesso em 25/09/2014.

SALOMON, K. R.; LORA, E. E. S. Estimate of the electric energy generating potential for diferente sources of biogás in Brazil. Biomas and Bioenergy, nº 33, p. 1101-1107. 2009. 
SANT'ANNA NETO, J. L.; TOMMASELli, J. T. G. O tempo e o clima de Presidente Prudente. FCT/UNESP, Presidente Prudente, 1 ed, 2009.

SOUZA, Cláudio Leite de. Estudo das rotas de formação, transporte e consumo dos gases metano e sulfeto de hidrogênio resultantes do tratamento de esgotos domésticos em reatores UASB. 2010. 127 f. Tese (Doutorado em Saneamento, Meio Ambiente e Recursos Hídricos). UFMG - Programa de Pós-Graduação em Saneamento, Meio Ambiente e Recursos Hídricos da Universidade Federal de Minas Gerais, Belo Horizonte, 2010.

SOUZA, C.L.; CHERNICHARO, C.A.L.; MELO, G.C.M. Methane and hydrogen sulfide emissions in UASB reactors treating domestic wastewater. In: 12th World Congress on Anaerobic Digestion, 2010, Guadalajara, Jalisco - México. Proceedings...México: IWA, 2010 .

SOUZA, M. E.; Criteria for the utilization, design and operation of UASB reactors. In: Seminar on Anaerobic Treatment in Tropical Countries, 1986, São Paulo, IAWPRC/CETESB, 1986.

STADLER, I.; BHANDARI, R.; MADEIRO, D. Implementation of small grid connected decentralized power generators using renewable energies. Cologne University of applied Sciences, Germany, 2010.

SILVEIRA, F. L. Física Geral - Imagens. Disponível em http://www.if.ufrgs.br/ lang/. Acesso em 25/09/2014.

TOPRAK, H. Temperature and organic loading dependency of methane and carbon dioxide emission rates of a full-scale anaerobic waste stabilization pond, Water Resources 29 (4). p. 1111-1119. 1995 apud EL-FADEL, M. \& MASSOUD, M. Methane emissions from wastewater management. Environmental Pollution, v. 114 p. 177-185. 2001

UNFCCC - UNITED NATIONS FRAMEWORK CONVENTION ON CLIMATE CHANGE . Approved Methodologies for Small Scale CDM Project Activities. Type III. AMS-III-H. Methane recovery in wastewater treatment (Version 16.0), in Clean Development Mechanism - CDM Methodology - Booklet (2013). Documento digital disponível em: http://cdm.unfccc.int/methodologies/DB/4ND00PCGC7WR3L0LOJTS6SVZP4NSU. Acesso em: 11 de maio de 2014.

USEPA - UNITED STATES ENVIRONMENTAL PROTECTION AGENCY. Turning a Liability into an Asset: A Landfill Gas-to-Energy Project Development Handbook. Landfill Methane Outreach Program. Washington, D.C.: U.S. Environmental Protection 
Agency. 1996. Disponível em: <http://www.epa.gov/landfill/res/pdf/handbook.pdf.>. Acesso em: 16/04/2013

2008a. Adapting Boilers to Utilize Landfill Gas: An Environmentally and Economically Beneficial Opportunity. Washington, D.C.: U.S. Environmental Protection Agency. 2008. Disponível em: <http://www.epa.gov/landfill/res/pdf/boilers.pdf >. Acesso em 18/02/2013.

2008b. Inventory of U.S. greenhouse gas emissions and sinks: 1990-2007 EPA430-R-05-003. Washington, D.C.: U.S. Environmental Protection Agency. 2009. Disponível em: <http://epa.gov/climatechange/emissions/usinventoryreport.html>. Acesso em: 09/07/2013.

VAN WYLEN, R.G. Fundamentos da Termodinâmica Clássica. Tradução da $5^{\text {a }}$ edição americana, 1998.

VAN HAANDEL, A. C., LETTINGA, G. Tratamento Anaeróbio de Esgotos: Um Manual para Regiões de Clima Quente. Epgraf. Campina Grande, 240 p. 1994.

VAZOLLER, R. F. Microbiologia e Saneamento Ambiental. IV Curso de tratamento biológico de resíduos, FURB/UFSC. Florianópolis. 1999.

VITORATTO, E. Tratamento de efluentes líquidos orgânicos - sistemas anaeróbios. Proacqua Processos de Tratamento de Efluentes e Com. Ltda. Faculdade Oswaldo Cruz, São Paulo, 2004.

VON SPERLING, M. Introdução à qualidade das águas e ao tratamento de esgotos: Princípios do tratamento biológico de águas residuárias. - Vol. 1 Departamento de Engenharia Sanitária e Ambiental da UFMG, 1995, 240 p.

VON SPERLING, M. Lodo de esgotos: tratamento e disposição final. Belo Horizonte. Departamento de Engenharia Sanitária e Ambiental - UFMG; Companhia de Saneamento do Paraná, 2001.

VON SPERLING, M.; CHERNICHARO, C.A.L. Biological wastewater treatment in warm climate regions. IWA Publishing, London, 2005. p. 1452.

WORLD BANK. State and Trends of Carbon Princing 2014. Washington, DC: World Bank. 2014. 